\title{
ETNOCONHECIMENTO SOBRE ABELHAS SEM FERRÃO: SABERES E PRÁTICAS DOS ÍNDIOS GUARANI M'BYÁ NA MATA ATLÂNTICA
}

\section{ARnaldo dos Santos Rodrigues}

\author{
Dissertação apresentada à Escola \\ Superior de Agricultura "Luiz de \\ Queiroz", Universidade de São Paulo, \\ para obtenção do título de Mestre em \\ Ecologia de Agroecossistemas.
}

P I R A C I C A B A

Estado de São Paulo - Brasil

Março - 2005 


\section{ETNOCONHECIMENTO SOBRE ABELHAS SEM FERRÃO: SABERES E PRÁTICAS DOS ÍNDIOS GUARANI M'BYÁ NA MATA ATLÂNTICA}

\section{ARnaldo dos Santos Rodrigues}

Bacharel em Ciências Biológicas

Orientador: Prof. Dr. DALCIO CARON

Dissertação apresentada à Escola
Superior de Agricultura "Luiz de
Queiroz", Universidade de São Paulo,
para obtenção do título de Mestre em
Ecologia de Agroecossistemas.

$P|R A C| C A B A$

Estado de São Paulo - Brasil

Março - 2005 
Dados Internacionais de Catalogação na Publicação (CIP) DIVISÃO DE BIBLIOTECA E DOCUMENTAÇÃO - ESALQ/USP

Rodrigues, Arnaldo dos Santos

Etnoconhecimento sobre abelhas sem ferrão: saberes e práticas dos índios guarani M'byá na Mata Atlântica / Arnaldo dos Santos Rodrigues. - - Piracicaba, 2005.

236 p. : il.

Dissertação (mestrado) - - Escola Superior de Agricultura Luiz de Queiroz, 2005.

Bibliografia.

1. Abelha - Indígena 2. Etnoconhecimento 3. Índios guarani 4. Mata Atlântica I. Título

CDD 638.12

"Permitida a cópia total ou parcial deste documento, desde que citada a fonte - O autor" 
Dedico este trabalho ao biólogo ERNEST MAYR.

Biólogo, professor, filósofo da biologia.

Ernest Mayr completa 100 anos de idade em julho de 2005.

Está produzindo o $26^{\circ}$. livro.

Ernest Mayr é professor até hoje na Universidade Harvard.

E em memória de Darel Adson Posey.

Uma vida dedicada à pesquisa etnobiológica 


\section{AGRADECIMENTOS}

Agradeço aos índios Guarani em referência a todas as pessoas que colaboraram direta ou indiretamente para a elaboração, execução e conclusão deste trabalho de mestrado. 


\section{SUMÁRIO}

Página

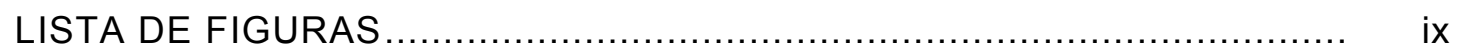

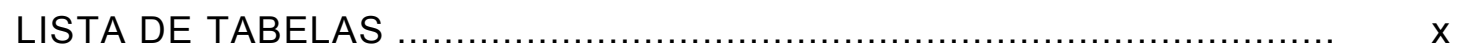

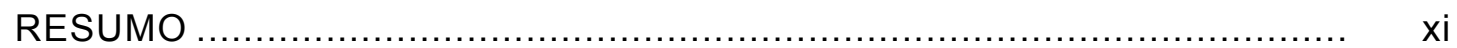

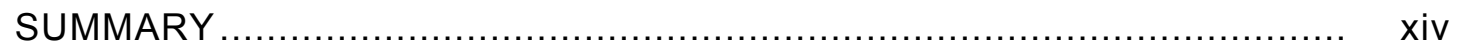

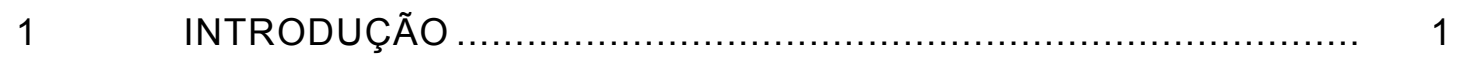

$1.1 \quad$ Porque estudar o conhecimento indígena sobre os insetos? ........ 1

1.2 Os insetos estudados em interface com as sociedades humanas. 5

1.3 Os primeiros dados etnografados sobre a entomofagia no Brasil 6

$1.4 \quad$ Pesquisas mais recentes sobre os insetos como alimento ........... 9

$1.5 \quad$ Os insetos e seus produtos no uso medicinal......................... 10

1.6 Os insetos nos rituais, mitos e religião ................................ 11

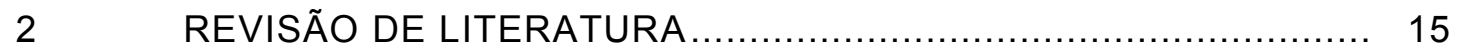

2.1 O conhecimento do conhecimento, na questão indígena ............. 15

$2.2 \quad$ Mudanças conceituais e metodológicas .................................. 16

2.3 Divergências, oposições e composições .................................. 17

2.4 Formulação teórica a partir da observação do comportamento do

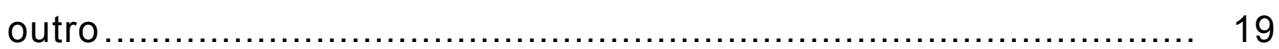

2.5 Entendendo a conceituação do outro conhecimento e do conhecimento do outro, para o uso na(s) Ciência(s) ................ 20

2.6 O conhecimento indígena! A quem nos referimos?................... 22

2.7 Uma resposta metodológica que abrange várias disciplinas para se estudar o conhecimento indígena sobre os insetos ............... 27

$2.8 \quad$ A interdisciplinaridade na etnobiologia .............................. 30

2.9 A etnoentomologia (...percepção...interação...relação...) ............ 32 
2.10 Dificuldades básicas encontradas com a pesquisa

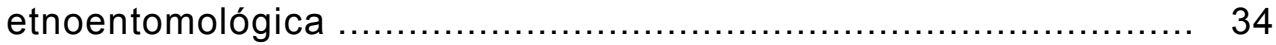

2.11 O que se deve considerar para pesquisar em etnobiologia e disciplinas correlatas? ................................................ 36

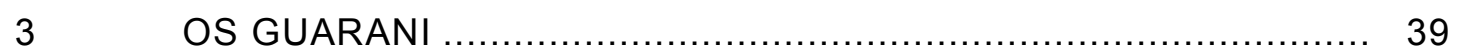

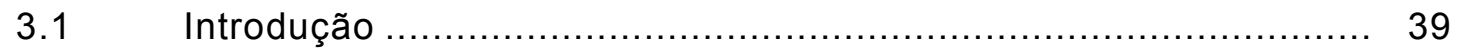

3.2 O início da desconstrução da história dos Guarani.................... 40

3.3 Quem eram e onde estavam os índios Guarani antes da invasão européia .

3.4 As lideranças e o aspecto carismático de condução organizacional Guarani ................................................... 46

3.5 A sistematização da exploração sobre os índios ..................... 49

3.6 As grandes missões ................................................... 51

3.7 Como o índio pode sobreviver mantendo sua base cultural (?)..... 53

3.8 O peso das invasões paulistas sobre o desenvolvimento das missões

3.9 O relacionamento entre paulistas e Guarani ......................... 55

3.10 Os Guarani e sua importância na construção de São Paulo ......... 57

3.11 As formas organizacionais dos Guarani resistiam à poderosa estrutura de opressão ...................................................... 61

3.12 Os Guarani hoje: comentários enfocando principalmente a aldeia Morro da Saudade .............................................. 65

3.13 Considerações adicionais sobre o presente capítulo ................... 76

$4 \quad$ MATERIAL E MÉTODOS .............................................. 77

$4.1 \quad$ Origem dos dados..................................................... 77

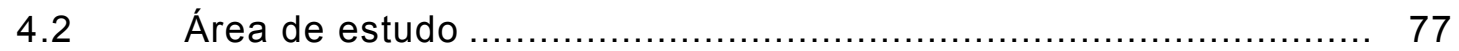

4.3 População e organização da aldeia Morro da Saudade ................ 83

$4.4 \quad$ Critérios que indicaram a área de estudo ............................ 84

4.5 Metodologias e técnicas empregadas para a coleta dos dados .... 84

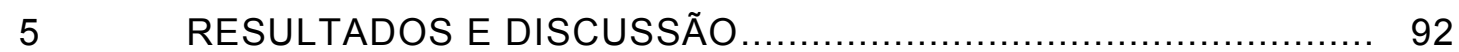

5.1 A percepção e a importância das abelhas: alguns aspectos na formulação do pensamento a respeito do equilíbrio homem/natureza na concepção dos Guarani 
5.2 (A) Abelhas sem ferrão (na ordem em que foram citadas pelo

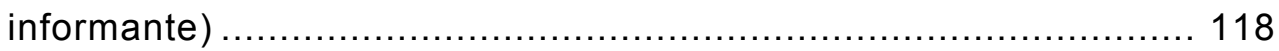

5.2.1 Etnoespécie: Jatei (idioma guarani, dialeto m’byá).................... 118

5.2.1.1 Utilização dos produtos................................................. 123

5.2.2 Etnoespécie: Ei pytã (idioma guarani, dialeto m’byá) .................. 130

5.2.2.1 Utilização dos produtos.................................................. 132

5.2.3 Etnoespécie: Guarykua (idioma guarani, dialeto m’byá) .............. 134

5.2.3.1 Utilização dos produtos.............................................. 137

5.2.4 Etnoespécie: Ei raviju (idioma guarani, dialeto m’byá) ................ 140

5.2.4.1 Utilização dos produtos............................................ 142

5.2.5 Etnoespécie: Yvy ei (idioma guarani, dialeto m’byá) .................. 144

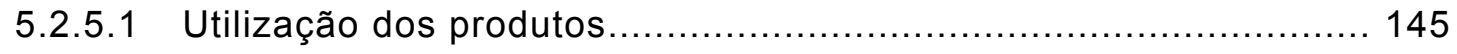

5.2.6 Etnoespécie: Ei tata (idioma guarani, dialeto m’byá) .................. 146

5.2.6.1 Utilização dos produtos.............................................. 147

5.2.7 Etnoespécie: El mirĩ (idioma guarani, dialeto m'byá) .................. 147

5.2.7.1 Utilização dos produtos............................................... 149

5.2.8 Etnoespécie: Ei mirĩ 'i (idioma guarani, dialeto m’byá) ................ 152

5.2.8.1 Utilização dos produtos............................................... 153

5.2.9 Etnoespécie: Ei irapua (idioma guarani, dialeto m’byá) .............. 154

5.2 .9 .1 Utilização dos produtos............................................ 156

5.2.10 Etnoespécie: Ei ruxu ou akã motõ (idioma guarani, dialeto m'byá) ...................................................................... 160

5.2.10.1 Utilização dos produtos................................................. 161

5.2.11 Etnoespécie: Mandori (idioma guarani, dialeto m’byá)................ 162

5.2.11.1 Utilização dos produtos................................................ 165

5.2.12 Etnoespécie: Ei tapexua (idioma guarani, dialeto m’byá).............. 166

5.2.12.1 Utilização dos produtos................................................... 167

5.2.13 Etnoespécie: Kraxai (idioma guarani, dialeto m’byá) .................. 167

5.2.13.1 Utilização dos produtos................................................ 168

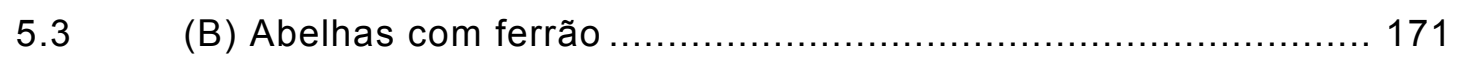

5.3.1 Etnoespécie: Mamanga (idioma guarani, dialeto m'byá) .............. 172

5.3.2 Etnoespécie: Mamanga guaxu (idioma guarani, dialeto m’byá)..... 172

5.3.3 Etnoespécie: Mamanga pytã (idioma guarani, dialeto m’byá) ....... 173 
5.3.4 Etnoespécie: Mamanga uũ (idioma guarani, dialeto m'byá) .......... 173

5.3.5 Etnoespécie: Mamanga pará (idioma guarani, dialeto m'byá) ....... 173

5.3.6 Etnoespécie: Mamanga ĩ (idioma guarani, dialeto m’byá)............ 174

5.3.7 Etnoespécie: Ei guaxu (idioma guarani, dialeto m’byá) ............... 175

5.3.8 Utilização dos produtos das abelhas com ferrão ....................... 179

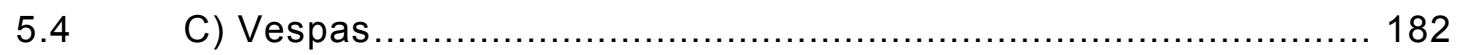

5.4.1 Etnoespécie: Kavy typexaĩ (idioma guarani, dialeto m’byá) .......... 183

5.4.2 Etnoespécie: Kavy taturã (idioma guarani, dialeto m’byá) ............ 185

5.4.3 Etnoespécie: Aguarakavy (idioma guarani, dialeto m’byá) ........... 185

5.4.4 Etnoespécie: Kavy xi (idioma guarani, dialeto m’byá)................. 186

5.4.5 Etnoespécie: Eixu guaxu (idioma guarani, dialeto m’byá) ............. 187

5.4.6 Utilização dos produtos das vespas .................................... 189

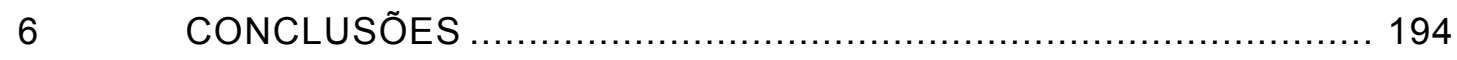

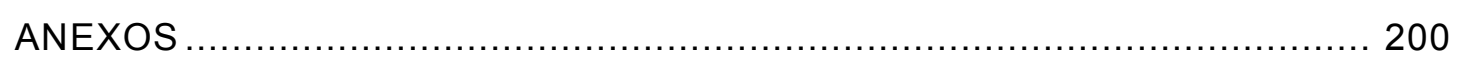

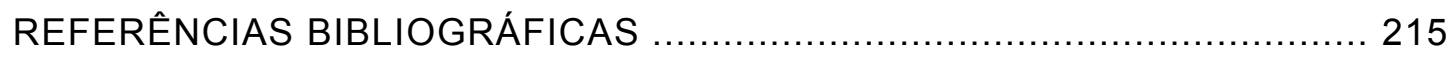




\section{LISTA DE FIGURAS}

Página

1 Karai Poty, esposa e sobrinhos (1989), ao fundo vê-se parte de sua moradia, onde hoje é a entrada da aldeia

2 Karai Poty (de camisa azul clara), esposa e sobrinhos, em 2005. Onde antes (1989) se via sua moradia, existe hoje um pinheiro adulto

3 Mapa histórico das Migrações Guarani

4 Mapa de localização: aldeias Morro da Saudade e Krukutu

5 Exemplo de moradias comuns na aldeia Morro da Saudade, atualmente

6 OPY (casa de rezas)

7 Construção abandonada da antiga Rádio Tupã (no $1^{\circ}$. plano vê-se o lago artificial)

8 A esquerda, o esquema do ninho de abelhas sem ferrão produzido pelo informante-chave na mata próxima a sua moradia e a direita, esquema de Nogueira-Neto (1970)

9 Esquema de abelha sem ferrão apresentada ao informante (a denominação foi declarada após ser apontada a parte referida) 


\section{LISTA DE QUADROS}

Página

1 Características antropomórficas declaradas pelo informante, espontaneamente, para a comparação entre as etnoespécies jatei e ei guaxu

2 Etnoespécies de abelhas sem ferrão, abelhas com ferrão e vespas .....

3 Uso de produtos de cada espécie de abelhas sem ferrão 


\title{
ETNOCONHECIMENTO SOBRE ABELHAS SEM FERRÃO: SABERES E PRÁTICAS DOS ÍNDIOS GUARANI M'BYÁ NA MATA ATLÂNTICA
}

\author{
Autor: ARNALDO DOS SANTOS RODRIGUES \\ Orientador: Prof. Dr. DALCIO CARON
}

\section{RESUMO}

Os insetos representam cerca de $53 \%$ dos táxons de todas as espécies vivas, constituindo $4 / 5$ do reino animal e, atualmente, fazem parte da alimentação de aproximadamente 1500 etnias, em todo o mundo. Grande parte da polinização das florestas tropicais, como, no caso do Brasil, atribui-se à atividade polinizadora desses animais, sendo as abelhas sem ferrão (Hymenoptera, Apidae, Meliponinae), contribuintes com até $90 \%$ da polinização das árvores nativas brasileiras. Estudos relacionados às abelhas sem ferrão no Brasil revelaram que a maior parte dos nomes populares que recebem são de origem indígena e, em alguns casos, a denominação científica também sofreu essa influência. Desde 1542 são observados, na literatura sobre os Guarani, o uso de insetos, incluindo-se a alimentação entre outras práticas. Esta pesquisa discorre sobre o conhecimento etnobiológico que os índios Guarani-m'byá possuem sobre as abelhas sem ferrão. O estudo foi realizado na "Área Indígena Guarani da Barragem" aldeia Morro da Saudade, de apenas 26,3 hectares, localizada no distrito de Parelheiros, bairro Barragem, periferia da cidade de São Paulo, SP, Brasil (coordenadas latitude: S-2352'16" e longitude: W-46 $38^{\prime} 58^{\prime \prime}$ ). A 
população atual é de aproximadamente 120 famílias, 600 indivíduos, falantes da língua Guarani, do tronco lingüístico Tupi, da família Tupi-Guarani, dialeto M'byá e, como segunda língua, adotaram o português do Brasil. O levantamento dos dados, inicialmente, se baseou no estudo etnográfico, permitindo conhecer a comunidade de maneira preliminar, como é comum em estudos das humanidades. Obedeceu, ainda, a duas etapas de coletas no campo que se distinguem qualitativamente, porém se completam. A primeira, de observação-participante, com o propósito de conhecer o comportamento da etnia, através de contatos diretos, em situações específicas ou não, nas quais a intervenção do pesquisador é reduzida ao mínimo. E, a segunda, de entrevistas livres e entrevistas semi-estruturadas, aplicadas a vários membros da comunidade e, com informantes-chave, reconhecidos como especialistas. Seguiu-se um roteiro pré-estabelecido com o intuito de garantir homogeneidade na abordagem. Em ambas as etapas a utilização da abordagem êmica prevaleceu, objetivando a obtenção de dados que possibilitassem centrar as coletas posteriores em um assunto específico. Tal abordagem resultou em registrar a maneira como os índios organizam, percebem, usam, aprimoram e transmitem seus conhecimentos sobre as abelhas sem ferrão, com o cuidado de não lhes impor parâmetros científicos. Concluiu-se que o conhecimento entre os Guarani-m'byá, a respeito das abelhas e insetos correlatos, foi transmitido oralmente de geração para geração, numa prática constante do aprendizado, inclusive aprimorando esse conhecimento, onde distingue-se 25 etnoespécies organizadas em três diferentes categorias: a) abelhas sem ferrão (13 etnoespécies), b) abelhas com ferrão (07 etnoespécies) e, c) vespas (05 etnoespécies), abrangendo: descrição, distribuição, nidificação, sazonalidade, dispersão, aspectos biológicos, do hábitat, ecológicos, fenológicos, detalhes morfológicos e etológicos, manejo e práticas de manipulação para extração de produtos, acondicionamento e semidomesticação de espécie e, utilização de seus produtos, destacando-se maior riqueza em detalhes para a categoria das abelhas sem ferrão. O conhecimento sobre as abelhas sem ferrão está presente, praticamente, entre todos os membros da comunidade, difere em 
profundidade com maior relevância entre os especialistas, melhores conhecedores.

Palavras-chave: Etnoconhecimento; Etnoentomologia; Índios Guarani; Abelhas sem ferrão 


\title{
ETHNOKNOWLEDGE ABOUT STINGLESS BEES: KNOW AND PRACTICES OF THE INDIANS GUARANI-M'BYÁ IN THE ATLANTIC FOREST
}

\author{
Author: ARNALDO DOS SANTOS RODRIGUES \\ Adviser: Prof. Dr. DALCIO CARON
}

\section{SUMMARY}

The insects represent about $53 \%$ of the taxons of all the alive species, constituting $4 / 5$ of the animal kingdom and, now, they are part of the feeding supply of approximately 1500 ethnias, all over the world. Great part of the pollination of the tropical forests, as, in Brazilian case is attributed to the pollination activity of those animals, being the stingless bees (Hymenoptera, Apidae, Meliponinae), responsible for up to $90 \%$ of the pollination of the Brazilian native trees. Studies related to stingless bees in Brazil revealed that most of their common names are of indigenous origin and, in some cases, the scientific denomination also suffered that influence. Since 1542 they are mentioned in the literature on the Guarani, being the use of insects included as feeding supply among other practices. This research deals with the ethnobiological knowledge the Indians Guarani-m'byá have about the stingless bees. The study was accomplished in the "Area Indígena Guarani da Barragem" in Morro da Saudade Village, with only 26,3 hectares, located in the district of Parelheiros, periphery of São Paulo, SP, Brazil (latitude: S-2352'16" longitude: W-46 $\left.{ }^{\circ} 38^{\prime} 58^{\prime \prime}\right)$. The current population is about 120 families, 600 individuals, native-speakers of the language Guarani, from the linguistic trunk Tupi, of the Tupi-Guarani family, dialect M'byá; as a second language, they adopted the Portuguese from Brazil. The raising of data initially based 
on the ethnologycal study, allowed to know the community in a preliminary way, as it is common in humanities' studies. It followed two stages of field collection qualitatively distinguished, but completed each other. The first was of participant-observation, with the purpose of knowing the behavior of the ethnia, through direct contacts, in specific situations or not, in which the researcher's intervention was reduced to a minimum. The second with free interviews and semi-structured interviews, applied to the several members of the community and with informants-key, recognized as specialists. A preestablished itinerary was followed aiming to guarantee the homogeneity in the approach. In both stages the use of the emic approach prevailed, aiming the attainment of data to make possible to center the subsequent collections in a specific subject. Such approach resulted in registering the way as the Indians organize, notice, use, perfect and transmit their knowledge on the stingless bees, being careful of not imposing them scientific parameters. The conclusion was that the knowledge among the Guaranim'byá, regarding the bees and correlative insects was transmitted vocally from generation to generation, in a constant practice of learning, besides perfecting that knowledge, bering distinguished 25 ethnospecies organized in three different categories: a) stingless bees (13 ethnospecies), b) bees with sting (07 ethnospecies) and, c) wasps (05 ethnospecies), including: description, distribution, nesting, seasonallity, dispersion, biological, habitat's, ecological, and phenological aspects, morphologic details and ethological, handling and manipulation practices for extraction of products, packing of species and semidomestication , use of the bees' products, in details for the category of stingless bees. The knowledge on the stingless bees is present, practically, among all members of the community, differing in depth with the largest relevance among the specialists.

Key words: Ethnoknowlwdge; Ethnoentomology; Indians Guarani; Stingless bees 


\section{INTRODUÇÃO}

\subsection{Porque estudar o conhecimento indígena sobre os insetos?}

As pesquisas sobre a grande diversidade de formas de vida revelam que os insetos somam mais da metade das espécies vivas existentes no Planeta. Este dado refere-se a cerca de $53 \%$ dos táxons de todas as espécies vivas, constituindo $4 / 5$ do reino animal (Delong, 1962). Mesmo analisado tais dados em termos de tempo geológico, a diversidade quantificada de insetos mensurados pela ciência é significativa com relação ao montante de vida no planeta. Segundo Wilson (1994), essa proporção se mantém desde o Carbonífero há mais de 300 milhões de anos. Isto é, quando o gênero Homo sequer apresentava vestígios de sua aparição, pode-se provar cientificamente que os insetos eram maioria entre as espécies viventes. Hoje pode-se verificar que eles estão presentes em qualquer ambiente: terrestre, aquático, no subsolo ou dossel das florestas (Wilson, 1997).

Outros dados que merecem atenção são referentes ao peso em biomassa, dominância numérica ou ecológica que os insetos representam. Segundo Morris et al. (1991) e Fisher (1998), quando se realiza uma medida em termos de biomassa, sabe-se que os principais constituintes dos ecossistemas terrestres são os insetos.

$\mathrm{Na}$ medida em que a tecnologia avança e novas metodologias se agregam aos estudos da diversidade da vida, os números apresentados anteriormente tendem a aumentar, ou seja, acredita-se que o número de espécies de insetos seja ainda maior, não apenas daquele atualmente 
catalogado e que no táxon das espécies eles tenham uma representatividade ainda mais significativa.

Mayr (1998) discutindo a descoberta da diversidade biológica, chama a atenção para o fato de que os insetos são estudados pela ciência há muitos séculos. Foram descobertos como sendo um objeto próprio de estudos científicos por volta de 1600 , sendo que a demonstração realizada por Francesco Redi, em 1668, de que os insetos não eram o resultado de geração espontânea, mas que se desenvolviam por ovos postos por fêmeas fertilizadas, marcou um grande salto no entendimento da diversidade das espécies.

Segundo Mayr (1998), nos séculos XVI e XVII, houve um enorme entusiasmo pela extraordinária diversidade do mundo vivo que seria ainda mais estimulado pelo sucesso de viagens, que convergiam para que os exploradores levassem para a Europa animais e plantas de todos os continentes.

O exponencial crescimento das coleções produziu, para aquele período, uma necessidade importante: a classificação. No entanto, um grande problema para a era das classificações surgiu a partir do que poderia ser considerada a "descoberta do mundo dos insetos". De alguma maneira, as pesquisas da época indicavam que o número de espécies de insetos era muito superior ao das plantas e dos outros animais e vários naturalistas começaram a dedicar quase toda sua atenção aos insetos.

Mayr (1998), atribui a influência que Lineu ${ }^{1}$ haveria de ter, sobre os trabalhos iniciais de vários naturalistas que se dedicaram a classificar uma infinidade de insetos e foram plantando metodologicamente as bases para que Lineu se tornasse famoso na macrotaxonomia. Tuxen (1973), afirma que os trabalhos de Réaumur foram seguidos por Geer que no parecer do autor influenciaram consideravelmente o sistema dos insetos de Lineu. Como se sabe, até nossos dias, a ciência tem como base o modelo de nomenclatura

1 Lineu é como se convencionou chamar "Carl von Linné", naturalista e médico sueco (17071778). Ele também é conhecido como o pai da taxonomia ou sistema de classificação taxonômico dos seres vivos, baseado em caracteres morfológicos e com nomenclatura binomial, que comumente é chamada de nomenclatura lineana. 
lineana para o estudo das espécies de todos os reinos que compõem ou compuseram a vida no Planeta.

A diversidade de espécies de insetos despertou tanto interesse nos séculos XVII e XVIII que naturalistas como Pierre Lyonnet, Ferchault de Réaumur, de Serres, Leonhard Frisch e Roesel von Rosenhof, prestaram grande contribuição para que se ampliasse o conhecimento sobre esses animais. Alguns dedicaram toda sua vida à identificação de novas espécies, embora, segundo Mayr (1998), na maioria das vezes os estudos tenham sido motivados pela pura satisfação dos autores descreverem suas descobertas, classificando e pormenorizando a anatomia desses animais.

Nem tudo corria bem no campo de novas identificações; esse trabalho apresentava um sério problema para os colecionadores. Na época não se conheciam métodos de conservação para as coleções e, segundo Mayr (1998), os insetos eram extremamente vulneráveis à destruição por outros insetos, os besouros dermestideos, dificultando muito a manutenção das coleções permanentes. Na verdade isso era quase impossível até que foram introduzidos a naftalina, os estojos adequados e herméticos de coleção e, ocasionalmente, a fumigação. Antes desses passos, vários estudiosos viam suas coleções desaparecerem, significando a perda de anos a fio de trabalho e dedicação.

Pode-se afirmar que, nos últimos 400 anos, houve um grande progresso nas metodologias de estudo dos insetos e a ciência continua identificando novas espécies dessa classe. Além disso, o número de espécies descritas vem crescendo e segundo Alves (1998), existe cerca de um milhão de espécies de insetos já descritas.

Atualmente, uma das discussões que causam grandes debates se fundamenta em qual seria a quantidade desses animais e sua representatividade nos táxons das espécies, discussão essa que tem levado a uma série de controvérsias entre os especialistas. 
Em 1952, funcionários do Departamento de Agricultura dos Estados Unidos, baseados na enorme quantidade de novas espécies que chegavam continuamente aos museus, estimavam que existiam cerca de 10 milhões de espécies diferentes em meio a uma diversidade desconhecida (Wilson, 1994). Dados referentes aos levantamentos de campo realizados por Erwin e Scott (1980), sobre coleópteros, nas copas das árvores das florestas panamenhas, são a base para que Erwin (1997), sustente a hipótese de que não são apenas 10 milhões o número estimado para as diferentes espécies de insetos viventes no Planeta. Para o autor, haveria em torno de 30 milhões deles integrando a diversidade de vida na Terra.

Erwin $^{2}$, citado por Jenkins Júnior (1997), refere-se ao gerenciamento, informação e conservação da biodiversidade e nos alerta para uma preocupação sobre o relativo conhecimento que a ciência possui sobre a classe Insecta nos trópicos. (Jenkins, op. cit.) considera que grande parte da diversidade de vida dos Insecta esteja localizada nas florestas tropicais, embora a maioria dos dados cadastrados cientificamente sobre a América Latina, por exemplo, esteja guardado em repositórios dos Estados Unidos. Sabe-se que os habitantes naturais dessas áreas são os índios, e que como é notório, são as áreas que sofrem uma enorme devastação pela especulação em grande escala de madeira, e pela implantação de agricultura predatória.

Algumas hipóteses e teorias dão conta de que a polinização das florestas tropicais, como, no caso do Brasil, é realizada quase que totalmente por insetos. Kerr et al. (1996), atribuem a polinização de $40 \%$ a $90 \%$ das árvores nativas brasileiras às abelhas sem ferrão (Hymenoptera, Apidae, Meliponinae), conhecidas popularmente como "abelhas indígenas". Pode-se afirmar que os trabalhos desenvolvidos ao longo de anos a respeito da dispersão de pólen a partir das abelhas sem ferrão, revelaram que esses insetos são fundamentais para que se mantenha uma diversidade nas florestas úmidas, evitando que ocorra uma perda significativa desse banco genético.

2 ERWIN, T.L. Tropical forests: their richenes. In: Coleóptera and other arthropod species. Coleopterists Bulletin, v.36, n.1, p.74-75, 1982. 


\subsection{Os insetos estudados em interface com as sociedades humanas}

A ciência entomológica no Egito foi alvo de um profundo estudo desenvolvido por Efflatoun (1929). Suas pesquisas confirmam que a entomologia estava presente no Egito como ciência popular e que os insetos faziam parte do cotidiano das populações egípcias. O mesmo se verifica sobre a entomologia no Oriente Médio com os trabalhos de Harpaz (1973), enquanto Scarborough (1979), demonstra a presença da entomologia como ciência popular na Grécia e Roma antigas.

Schwarz (1948), realizou um dos mais completos estudos sobre as abelhas sem ferrão entre os Maya da América Central. Em seus estudos foram constatados que os Maya manipulavam geneticamente diferentes espécies de abelhas, realizando melhoramento genético para aumentar a produção de mel, garantir matrizes mais adequadas ao ambiente e manter a diversidade de forma sustentável.

Estudos atuais sobre o "Códice Tro-Cortesiano" (Códice Maya depositado no Museu de América de Madrid) realizados por Cappas-e-Sousa (1995), demonstram que os Maya desenvolveram uma íntima relação com as abelhas sem ferrão e que esses insetos estavam relacionados às questões religiosas e à cosmologia, segundo as concepções daquela etnia. Adornos específicos eram especialmente desenvolvidos, reproduzindo abelhas sagradas e o deus-abelha.

O antropólogo Jean Vellard (1939), realizou um criterioso estudo sobre a importância das abelhas e vespas para os Guaiaky, índios do Paraguai. Segundo o autor, esses índios desenvolveram uma convivência não apenas relacionada à questão de uso alimentar dos produtos desses insetos, mas envolve também sua influência nos mais diversos aspectos da vida coletiva daquela etnia. Esses índios foram considerados pelo autor como profundos conhecedores de uma grande variedade de abelhas. 
Estudos relacionados às abelhas sem ferrão no Brasil revelaram que a maior parte dos nomes populares dados a esses insetos é de origem indígena (Nogueira-Neto, 1970; Lenko \& Papavero, 1979). Nogueira-Neto (1970), afirma que muitas das denominações científicas dessas abelhas, também provêm diretamente de sua origem lingüística tupi.

Ao se estudar cronologicamente os trabalhos a respeito dos insetos em contraposição à história das humanidades, ver-se-á que esses animais aparecem como adornos, desenhos, e esculturas em diversas etnias, tanto naquelas extintas como no presente, fazendo parte do universo e imaginário das humanidades desde todos os tempos.

No Brasil atual temos como exemplo os trabalhos desenvolvidos por Posey (1979; 1980; 1982 entre muitos outros) que estudou os índios Kayapó e aprofundou suas pesquisas com relação aos insetos sociais e à interação existente entre esses índios e as abelhas sem ferrão.

\subsection{Os primeiros dados etnografados sobre a entomofagia no Brasil}

Resgatando alguns dados a respeito dos insetos e os índios no Brasil, quando os europeus chegaram ao continente, nota-se um aspecto interessante com relação à preocupação que houve desde os idos de 1500 na tentativa de descrever o uso dispensado pelos índios Guarani a alguns desses animais. Em 1542, segundo Noelli (1993), houve o primeiro registro de uma descrição sobre o uso de insetos como alimento pelos índios Guarani:

$$
\begin{aligned}
& \text { "(..) no oco destas canas havia uns insetos } \\
& \text { brancos, tão grossos e compridos como um dedo, os } \\
& \text { quais a gente assava para comer, e saía dele tanta } \\
& \text { gordura, que bastava para fritar-se muito bem, e os } \\
& \text { comiam toda gente e os tinham como uma comida }
\end{aligned}
$$


muito boa (...)" (Cabeza de Vaca ${ }^{3}$ citado por Noelli, 1993, p.366)

O jesuíta José de Anchieta, em 1560, descreve a entomofagia entre os Tupinambá, sobre os insetos do oco da taquara (Guadua trinii), que se apresenta muito similar ao que Cabeza de $\mathrm{Vaca}^{4}$, havia documentado 18 anos antes sobre os Guarani ${ }^{5}$. Muito tempo depois, no século XX, Ihering, $\mathrm{R}^{6}{ }^{6}$, citado por Noelli (1993), estudando esse inseto descobriu que se tratava do Lepdóptero Morpheis smerintha.

Cabeza de Vaca (1984), menciona a importância do mel para os Guarani em relato de suas viagens de 1541 e 1542, atribuindo a esse produto valor intrínseco na cultura daqueles índios.

Também são muito comuns os apontamentos a respeito das formigas Atta sexdens, conhecidas até os dias de hoje pelo nome que os índios Ihes atribuíam: "içá", cujo significado no idioma guarani é "formiga que se come" (Bueno, 1987). Anchieta ([1560] 1988, p.132), descreve a técnica de preparo das formigas para o consumo:

$$
\begin{aligned}
& \text { "(...) enchem seus vasos, isto é, certas cabaças } \\
& \text { grandes, voltam para casa, assam-nas em vasilhas } \\
& \text { de barro e comem-nas; assim torradas, conservam- } \\
& \text { se por muitos dias, sem se corromperem (...)". }
\end{aligned}
$$

Ao que constatou, essas formigas podiam ser consumidas cruas ou torradas (Melià et al., 1976), e se sabe que cada formigueiro no auge da produção, pode fornecer entre 10 e $16 \mathrm{~kg}$ das mesmas (Dufour, 1987).

3 CABEZA DE VACA, A.N. Naufrágios y comentários. Madri: História, 1984. 318p.

4 CABEZA DE VACA, op. cit.

5 Cf. ANCHIETA, [1560] (1988).

6 IHERING, R. von. Fauna do Brasil: texto explicativo do Atlas da Fauna do Brasil. São Paulo: Secção de Obras de "O Estado". 1917. 125p. 
Gabriel Soares de Souza, citado por Lenko \& Papavero (1979) também registrou em 1587 o habito entomofágico entre os índios: "criam-se na mesma terra outras formigas, a que os índios chamam de içás... A estas formigas comem os índios torradas, sobre o fogo, e fazem-lhe muita festa".

Outro inseto é registrado com muita atenção pelo padre Diogo Ferrer que, inclusive, compara a alimentação dos Guarani com uma passagem bíblica:

$$
\begin{aligned}
& \text { “(...) sustentou-se de gafanhotos, indo seus meninos } \\
& \text { cada dia recolher uma panela deles (...) de sorte } \\
& \text { que não tem que disputar os intérpretes se foram } \\
& \text { gafanhotos verdadeiros ou outra coisa com que se } \\
& \text { sustentou São João Batista, porque aqui há } \\
& \text { experiência que um se pode sustentar com eles e, } \\
& \text { ainda, sem mel silvestre (...)" (Ferrer, [1633] 1952, } \\
& \text { p.33). }
\end{aligned}
$$

Embora tenha demonstrado exemplos de recuperação de vestígios de insetos entre refugos arqueológicos onde pôde mensurar as quantidades comparando-as aos vestígios de outros tipos de alimentos, Sutton (1990), atribui aos etnógrafos as informações mais qualificadas e em quantidade generosas, que podem fornecer várias pistas sobre esse costume. A entomofagia entre os Guarani começa a ser aborda com maior profundidade pela arqueologia na década de 1990 (Schimitz \& Gazzaneo, 1991). Assim, poucos trabalhos estão relacionados a esse assunto na literatura, e segundo Noelli (1993), poucas foram as escavações e muitas vezes as prospecções foram consideradas escavações, apontando para a conclusão que haveria uma distância tão grande entre os métodos e os procedimentos da arqueologia Guarani e da Arqueologia que parecem ser disciplinas cientificas diferentes.

$\mathrm{Na}$ antropologia, os estudos a respeito da alimentação à base de insetos, pelos índios Guarani, ocorrem direta ou indiretamente através principalmente de etnógrafos como Cadogan (1949; 1955; 1959; 1992); Martinez-Croveto (1968); Melià et al. (1976). 


\subsection{Pesquisas mais recentes sobre os insetos como alimento}

Com relação ao consumo de insetos na alimentação, estudos recentes (Costa-Neto, 2003) comprovam que esses animais são um importante recurso alimentar natural e renovável, apresentando um considerável valor nutritivo por serem ricos em proteínas, lipídeos, aminoácidos, sais minerais e vitaminas. Também são importantes fontes de aminoácidos essenciais (Chen, 1994; Ega \& Ola, 1998). São abundantes no meio ambiente e atualmente ainda participam da dieta de diversas etnias com ocorrência muito comum entre grupos da Amazônia (Beckerman, 1979; Coimbra Junior, 1984; Defoliart, 1990; Dufour, 1987; Lenko \& Papavero, 1979; Posey, 1980; 1983, 1983a, 1986; Ribeiro \& Kenhiri, 1987).

Segundo Ramos-Elorduy (2000) os estudos sobre a importância dos insetos como fonte alimentar, revelam que 1509 espécies são utilizadas como alimento nos cinco continentes, por cerca de três mil diferentes grupos étnicos. De acordo com a autora (1998), o maior grupo dos insetos comestíveis é o grupo dos Coleópteros. Esse grupo, popularmente conhecidos como besouros, participam com um total de 344 diferentes espécies, seguido pelos Ortópteros (baratas, grilos, gafanhotos, esperanças, louva-a-deus), com um total de 239 diferentes espécies e pelos Lepdópteros (borboletas e as mariposas), com um total de 235 diferentes espécies.

Nos costumes das sociedades europeizadas e americanizadas é quase inconcebível o uso dos insetos ou de seus produtos como alimento. No entanto, conscientemente ou não, um dos produtos das abelhas, o mel, é consumido em toda parte e a sua industrialização é, reconhecidamente, uma atividade rentável. Dufour (1987), afirma que as abelhas são consideradas como o único inseto sistematicamente explorado para a alimentação humana. Mas, ao se perguntar às pessoas se elas consomem algum produto elaborado por insetos, é quase certo que a resposta será negativa. Segundo Posey (1987), os preconceitos culturais funcionam como uma barreira e são eles os 
principais fatores que limitam o consumo de insetos, nas sociedades ocidentais.

Ainda sobre a entomofagia, existem registros de crenças relacionadas ao uso alimentar de insetos. Para citar um exemplo, pode-se fazer referência aos índios Chuh da Guatemala que coletam os ninhos da vespa do gênero Polistes em busca das pupas ${ }^{7}$. Os Chuh acreditam que os olhos pigmentados de preto dos insetos lhes darão poderes procriativos, capacitando-os a gerarem crianças de olhos grandes (Spradbery, 1973).

\subsection{Os insetos e seus produtos no uso medicinal}

Os insetos também constituem uma parcela significativa dos recursos animais (zooterápicos) usados na medicina tradicional. Diferentes etnias, desde os tempos antigos, usaram não apenas os insetos, mas também os produtos por eles produzidos ou deles extraídos na formulação terapêutica de seus costumes e sistemas medicinais ${ }^{8}$. Os chineses, por exemplo, segundo Zimian et al. (1997), usam o bicho da seda há mais de três mil anos, e segundo Zimmer (1993) a utilização de larvas de moscas para fins medicinais pode ser constatado estudando-se os costumes dos Maia. Segundo o autor, os Maia utilizavam essas larvas há mais de mil anos.

Segundo Ramos-Elorduy (2000), existem 374 espécies de insetos catalogados como de usos medicinais (entomoterápicos) só no México e a busca de substâncias de valores farmacológicos pela ciência, também tem nos insetos um de seus objetos.

Os avanços tecnológicos e a possibilidade de grandes lucros, a partir da síntese artificial dos princípios ativos de determinadas substâncias

\footnotetext{
7 A pupa é o estado intermediário entre a larva e a imago, que é a forma definitiva do inseto após suas metamorfoses e na qual se the define o sexo, nos insetos holometabólicos.

8 Para uma leitura mais detalhada sobre o tema consultar: Andrade (2000); Barajas (1961); Beattie (1992); Caillois (1938); Chen (1994); Conconi \& Pino (1988); Fasoranti (1997); Green (1998); Hitchcock (1962); Namba et al. (1988); Ott (1998); Posey (1987a); Ratcliffe (1990); Seignobos et al (1996); Souza-Dias (1995); Valli (1998); Weiss (1925, 1930, 1946, 1947), Werner (1970). As referências completas constam no capítulo "referências bibliográficas".
} 
encontradas naturalmente nos insetos, têm levado os laboratórios fabricantes de fármacos a disputarem espaço nessa linha de pesquisas. Kunin \& Lawton (1996), citam que drogas anticancerígenas consideradas importantes foram isoladas das asas de borboletas da espécie Catopsilia crocale e das pernas do besouro da espécie Allomyrina dichotomus.

Outra substância, como, o sódio de cantaridina, tem seu uso medicinal para o tratamento e cura de câncer de pulmão e fígado (Zimian et al. 1997). A cantaridina (cuja fórmula é: $\mathrm{C}_{10} \mathrm{H}_{12} \mathrm{O}_{4}$ ), é o princípio ativo da Cantharis vesicatoria, um coleóptero que curiosamente recebe como denominação popular o nome de "mosca espanhola". O uso medicinal desse inseto é muito antigo, porém não se descobriu desde quando o homem faz esse uso.

As neurotoxinas ( $\alpha$ e $\beta$ popilidotoxinas) encontradas na peçonha de insetos da família dos pompilídeos ${ }^{9}$, são, segundo Kono et al. (1999), toxinas que têm muita utilidade para a investigação neurocientífica básica, não sendo descartada a possibilidade de desenvolvimento de agentes terapêticos do trato neurológico.

\subsection{Os insetos nos rituais, mitos e religião}

As cerimônias indígenas sempre foram documentadas por viajantes e cronistas além de outros visitantes que estiveram em diferentes etnias. Existe uma verdadeira atração por aquilo que qualquer "outro" realize de diferente: o exótico, o estranho e também, o inexplicável. Muitas vezes os detalhes das etnografias são bastante interessantes, mas nem sempre estão registrados no contexto cultural (Posey, 1987) e com uma abrangência metodológica "êmica", transformando os dados em fragmentos que muitas vezes pouco podem acrescentar aos estudos entomológicos e etnoentomológicos.

9 Família de insetos Himenópteros, que compreendem as vespas caçadoras de aranhas. Atacam as aranhas paralisando-as com a peçonha inoculada na ferroada, depositam seus ovos sobre o corpo do Aracnídeo que servirá de repasto para as larvas quando os ovos eclodirem. 
A mitologia apresenta um grande número de registros sobre a participação dos insetos em seu corpus. Seria muita pretensão eleger entre tantos autores alguns que melhor representassem, por intermédio de seus estudos as pesquisas sobre esse tema. No entanto, alguns trabalhos serão citados para que sirvam de referência inicial sobre o assunto.

Os estudos de Wyman \& Bailey (1964), sobre os índios norte americanos, Navajo, realizam um levantamento de muitas espécies de insetos que estão relacionados ao mundo mítico dessa etnia. O'Bryan (1956), publicou um artigo sobre a origem dos mitos dos índios Navajo; o mito "Dîné", sobre a origem desse povo, fala de vespas, formigas e besouros que originam o homem e a mulher.

Bushnell (1910) e Mooney (1972), discutem a participação dos insetos como figura central nos sistemas de crenças indígenas da região sudeste da América do Norte, onde os índios Choctaw acreditam que os gafanhotos e os homens foram irmãos em certa época e foram criados ao mesmo tempo quando configuravam uma vida em comum, no início de tudo ${ }^{10}$. Segundo Mooney (1972), para os Cherokee certa espécie de besouro foi responsável pela formação da terra seca, pois trazia a lama que estava submersa para que, a partir dela, se formassem a terra seca.

Siganos ${ }^{11}$ citado por Costa-Neto (2002), refere-se à importância das abelhas:

\begin{abstract}
"a abelha era um dos insetos que mais se destaca por sua importância na cosmologia de diferentes grupos: Rainha dos deuses para os Hitita; lagrima de Ré; companheira de Apolo; 'nutrís' de Zeus e dos homens da Idade do Ouro; mãe dos deuses para os
\end{abstract}

10 Cf. Bushnell (1910)

11 SigANOS, A. Bestiário Mítico. In: BRUNEL, P. (Org.). Dicionário de mitos literários. Rio de Janeiro: José Olympio, 1997. p.117-137. 
índios Guarani; esposa do deus dos mortos para os Bosquímanos".

Um trabalho interessante foi realizado por Jara (1996), sobre os elementos que definem a noção de gêneros para os Andoke. Segundo o autor, esses índios colombianos acreditam que as abelhas estão associadas às estrelas e também a seus antepassados. Para os Andoke, os descendentes das abelhas se transformaram em antas depois de cometerem o canibalismo. Jara (op. cit.), explica que essa forma de entender a relação existente entre os animais em seu mundo com os homens é representada no sistema de classificação, uma vez que, segundo o autor, antas e abelhas estão reunidos em categorias taxonômicas hierarquicamente ordenadas. A forma como os Andoke vêem os animais influencia a organização taxonômica da qual se valem para ordenar seu mundo.

Os escaravelhos tiveram uma participação importante no mundo egípcio antigo (Carrera, 1995). Vários autores citam a importância de espécies desses coleópteros em diferentes dinastias egípcias. Existem registros entre os anos de 2445 e 525 a.C. sobre os coleópteros sagrados e, segundo Clausen (1954), esses insetos são encontrados junto às múmias de reis e autoridades da administração faraônica.

Pesquisas sobre o Códice Tro-Cortesiano que se encontra no Museu América de Madri, revelaram que as abelhas sem ferrão eram veneradas pelos Maya, segundo Cappas-e-Sousa (1996):

"Las abejas sin aguijón se hallan íntimamente ligas al culto del Jaguar y al del Par Progenitor (el Sol e la Luna) que crean la vida. Así, estas abejas se relacionan con todos los dioses de panteón Maya".

No Brasil, trabalhos sobre os Kayapó, desenvolvidos por Darel Posey ao longo de praticamente toda a sua vida, apresentam vários mitos e dezenas de insetos que estão ligados a eles. Posey (1983; 1986; 1987, entre 
outros trabalhos), conduz o leitor a uma rica bibliografia a respeito do tema, incluindo outras tribos indígenas das Américas. 


\section{REVISÃO DE LITERATURA}

\subsection{0 conhecimento do conhecimento, na questão indígena}

As populações indígenas de uma forma geral interagem com o seu meio ambiente mantendo um incansável relacionamento com seu habitat. Tal interação Ihes proporciona acumular uma sabedoria que inclui não apenas uma compreensão do todo, mas justifica sua relação específica com o entendimento dos fenômenos naturais como a umidade, a luminosidade, a floração, o vento, as chuvas, o frio e o calor, as marés, além de um conhecimento minucioso sobre várias das diferentes espécies que compõem a biodiversidade. Classificam o ambiente, os substratos e o mais notável é que sempre se incluem na composição do todo, e reconhecem que dele fazem parte.

Nesse relacionamento com a natureza, segundo Ribeiro (1991), conscientemente ou não, o índio defende e preserva a natureza no desenvolvimento de uma política agrícola e demogenética. A autora se refere ao melhoramento genético numa intervenção que produza resultados que não impeçam um relacionamento harmonioso com seu nicho ecológico. Essa intervenção antrópica é considerada significativa na formação de diversos tipos de floresta na Amazônia.

Discutindo a influência cultural no relacionamento homem/natureza, Ballé (1989), sustenta a hipótese de que mesmo que predominem as bases excessivamente naturalísticas de que a formação da floresta amazônica seja proveniente da estrutura e da idade geológica do substrato, ou da composição da estrutura do solo, ou da quantidade de água e drenagem, esses são, segundo o autor, fatores que podem ser relacionados com a fitogeografia, 
combinados ou individualmente. No entanto, a influência cultural deve ser levada em consideração uma vez que grandes trechos da mata amazônica podem ser identificados como "matas culturais", isto é, sob influência humana, e neste caso: indígena.

Ballé (1989) refere-se ainda aos relatórios da Organização das Nações Unidas para Agricultura e Alimentação:

\begin{abstract}
“(..) os primeiros inventários florísticos da FAO na Amazônia brasileira, dos quais surgiram evidências de que certas matas não eram simplesmente 'primárias', Sombroek (1966) escreveu que 'os índios provavelmente exerceram uma influência considerável nas florestas amazônicas' ".
\end{abstract}

Para Lévi-Straus (1970) a ação dessas populações no ambiente em que vivem e desenvolvem sua organização, Ihes permite compreender a lógica do equilíbrio do ecossistema e suas interligações físicas e biológicas.

\title{
2.2 Mudanças conceituais e metodológicas
}

Pode-se afirmar que com a Antropologia cognitiva, as investigações que enfocam o caráter "etno", envolvendo outras ciências tornaram-se mais abrangentes e ganharam maior amplitude. Coincidindo com esse movimento, surgiu na década de 1950, na Universidade de Yale (EUA), a nova etnografia, etnografia semântica ou etnociência.

O termo etnociência apareceu pela primeira vez no livro "Outline of Cultural Materials" de autoria do pesquisador Murdock e colaboradores, editado em 1950. Segundo Clément (1998a), etnociência passou a significar, por redução, tanto o aspecto puramente classificatório relacionando homem e natureza, como o método de análise semântico utilizado com objetivos de revelar esse mesmo aspecto. A grande atração que se remete à etnociência está em sua promessa de encontrar as representações paradigmáticas 
precisas e altamente elucidativas dos fenômenos culturais que estariam associados às descrições lingüísticas da fonologia e da gramática (Harris, 1976).

A etnociência revolucionou os trabalhos de campo e segundo Hays (1983), principalmente a natureza das descrições e análises etnográficas. Já a etnoclassificação assume considerável importância na etnociência como explica Cardona ${ }^{12}$ citado por D'Olne Campos (2002):

$$
\begin{aligned}
& \text { “... todas as formas de classificação que o homem } \\
& \text { escolheu para dar ordem e nome àquilo que ele vê } \\
& \text { entorno de si são substancialmente equivalentes, } \\
& \text { são todas substancialmente científicas, se mais não } \\
& \text { fosse que pelo sentido óbvio através do qual o } \\
& \text { substantivo scientia deriva de scio, 'sei', e portanto } \\
& \text { toda organização do nosso conhecimento é uma } \\
& \text { scientia; cada uma corresponde a uma fundamental } \\
& \text { exigência do homem, aquela de reencontrar-se, } \\
& \text { medir-se, dar-se ordem medindo, conhecendo, } \\
& \text { ordenando tudo que se encontra em torno, } \\
& \text { semelhante ou não a ele”. }
\end{aligned}
$$

\subsection{Divergências, oposições e composições}

Com relação à etnoclassificação, e por que não dizer ao etnoconhecimento, existem duas linhas que divergem: intelectualista (ou cognitiva) e utilitarista (ou econômica). A corrente intelectualista apresenta, segundo Clifton (1968) duas teorias antropológicas que consideram a cultura essencialmente uma "construção mental". A primeira está associada ao estruturalismo francês de Lévi-Strauss, que pode ser apresentada pelo pensamento que define "... as espécies animais e vegetais não são conhecidas na medida em que sejam úteis; elas são classificadas úteis ou interessantes

12 CARDONA, G.R. La Foresta di Piume, Manuale de Etnoscienza. Roma: Ed. Laterza. 1985.193p. 
porque primeiro são conhecidas ... (Lévi-Strauss, 1970)”. O autor, muito referenciado em artigos relacionados ao estudo da cultura indígena, assinala que os nativos utilizam categorias abstratas da mesma forma que os ocidentais. Segundo Lévi-Strauss, isso se deve a uma razão prática que governa o pensamento dito selvagem, a uma necessidade de objetivar o mundo percebido e ordenar o universo circundante. A ciência do "concreto" em oposição à ciência do "abstrato" é aquela que classifica e explica através de um raciocínio exclusivamente metafórico, ou seja, um raciocínio fundamentado numa relação de semelhança que se submete a uma adequação que confere unidade à existência entre o sentido próprio e o figurativo. Segundo o autor, não se pode ignorar o caráter "científico" desses procedimentos, pois essas ações não pretendem somente classificar elementos, mas também teorizar e explicar o mundo.

A segunda teoria antropológica ligada à linha intelectualista tem como um de seus expositores Brent Berlin, para quem a classificação e nomenclatura de plantas e animais na sistemática de folk, são essencialmente idênticas em todas as línguas e podem ser descritas por um pequeno número de princípios gerais e trans-culturais de nomenclatura (Berlin, 1992). Na mesma obra ele considera que a base da classificação etnobiológica se fundamenta pelas similaridades e diferenças morfológicas, afirmando que só raramente a classificação está apoiada em considerações funcionais como, por exemplo, sua utilidade cultural.

A linha divergente da intelectualista é a utilitarista que pode ser verificada ao se estudar as apresentações de Hunn que atribui aos povos a classificação das espécies, tanto animais como vegetais, porque elas thes são úteis e que tal condição utilitarista na vida, principalmente na vida cultural, irá definir e viabilizar ou não o mundo a ser conhecido (Hunn, 1982). Em síntese, a linha utilitarista define que os conhecimentos culturais do mundo natural são devidos ao seu uso e todo o saber, por mais sistematizado que seja, persiste em função da simples utilidade prática. 
No entanto, a abordagem mais apropriada para se tratar o assunto parece ser a de Clément (1995) e Nazarea (1999) que consideram que os seres humanos podem proceder a suas classificações simultaneamente, tanto no nível utilitarista defendido por Hunn, como no cognitivista ou intelectualista, defendido por Lévi-Strauss.

Quando se analisa metodologicamente tal proposição, supõe-se que, na verdade uma abordagem definitivamente se complementa, a partir da sua fusão com a outra.

\subsection{Formulação teórica a partir da observação do comportamento do outro}

É interessante notar que as abordagens discutidas acima têm em comum o fato de ligarem o conhecimento ao comportamento, como é explicado por Gragson \& Blount (1999). Essa condição propicia uma tendência de observação limitada, muitas vezes ao momento da observação, podendo imprimir ao pesquisador a forte determinação em tentar explicar todas as ações como modelos de uma cultura e associar diretamente uma ação a uma circunstância comportamental. Tais análises se distanciam da contextualização de tempo e espaço enquadrando a manifestação observada numa instrumentalização modelar que muitas vezes é transferida de um para outro grupo. O procedimento resulta na tentativa de explicar que determinado comportamento é universal, isto é, quando ocorre "aquele comportamento", certamente terá um mesmo significado qualquer que seja o grupo que o manifeste, o que nem sempre é verdade.

De fato, a maneira pela qual os membros das mais diversas etnias diferenciam a flora e a fauna agrupando-as de formas específicas, pode ser interpretado como sendo, tecnicamente, uma manifestação encontrada para contraposição à diversidade biológica do ambiente, ou seja, uma tentativa de compreendê-la e classificá-la. Tal particularidade demonstra um entendimento qualitativo e quantitativo organizacional que, segundo Brown (1981), é uma característica comum a todo ser humano. As categorias construídas individualmente ou pela coletividade podem ser interpretadas como 
construções lingüísticas que capacitam uma cultura a dar ordem a seu universo (Greene, 2000), possibilitando que se crie uma relação entre pessoas e fenômenos, sejam eles físicos ou não. Giannini (1995), interpreta essa ação como sendo uma forma de perceber a natureza pelas diferentes sociedades tradicionais. Segundo a autora, essas sociedades possuem um conhecimento minucioso da diversidade biológica e ecológica (referindo-se às variedades de ecossistemas). Elas ordenam e classificam a natureza, “(...) seja simplesmente pelo saber em si, seja pela satisfação de impor um padrão ou de ordenar o "caos'”. A autora sustenta a hipótese de que, ao agrupar e nomear de forma escalonada e abrangente, significa que se está pensando taxonomicamente, e que isso é "algo compartilhado por todas as sociedades humanas".

\subsection{Entendendo a conceituação do outro conhecimento e do conhecimento do outro, para o uso na(s) Ciência(s)}

Admitindo-se que exista uma lógica, coerência de raciocínio, no processo usado nas construções nominais representativas que envolvem objetos, formas diferentes de vida, de nichos ecológicos, de variedades de extratos do ambiente natural, ou mesmo das variedades dos ecossistemas e dos fenômenos naturais ou espirituais, e enfim, do conhecimento não científico, o exercício de interpretá-la, pode ajudar a ciência a entender o pensamento e atitudes a respeito dos saberes e conceitos desenvolvidos no âmbito de outros sistemas de conhecimento.

Com relação às culturas indígenas, ao entender o processo de construção conceitual, classificação e por fim de interpretação, é possível, por intermédio do método de geração de teste de hipóteses, viabilizar o que Posey (1992) considerou como um atalho para que os etnobiólogos concluam os objetivos de apresentarem hipóteses que possam ser testadas sobre os conceitos indígenas, provendo a ponte metodológica para interligar a pesquisa científica com outros sistemas de conhecimento, viabilizando o diálogo entre o conhecimento científico e outras formas de conhecimento. 
Embora pareça apenas correto pressupor que atualmente o conhecimento indígena não pode ser desconsiderado pela pesquisa científica, segundo Ellen \& Harris (1996), esse conhecimento, mais do que isso, não pode ser ignorado no contexto do desenvolvimento econômico atual, sendo que sua aplicação na indústria e comércio está sendo bastante importante na geração de muitas riquezas.

Aparentemente, a condição da ciência em termos do comportamento de seus "alimentadores", conjectura que o "outro" conhecimento, ou seja, o não-científico o qual, necessariamente neste estudo, deverá ser definido como não-global ou não-mundializado, pode servir para melhorar o conhecimento científico, principalmente se voltado ao utilitarismo. No entanto, seria quase uma ingenuidade imaginar que alguma vez o estudo do conhecimento "do outro" teve caráter menos político ou menos intencional de ampliação de poder, seja para uso comercial ou político-ideológico. O estudo do conhecimento sempre propiciou a apropriação sobre o conhecimento local, da sociedade estudada, porém nem sempre ocorre o reconhecimento desse fato.

Como foi visto anteriormente, o conhecimento sobre os insetos, no caso dos viajantes do século XVI, ou dos jesuítas que etnografavam o conhecimento sobre esses animais no universo das populações indígenas viventes no Brasil, conscientemente ou não, tal ação tinha por objetivo absorver novos conhecimentos e sempre que possível transferi-los, adaptá-los e mercantilizá-los para os costumes ocidentais. Atualmente, uma complexa metodologia, garante que os cronistas e viajantes, entre outros passageiros de tempos atrás, sejam substituídos por pesquisadores, muitas vezes "catequizados" pela ciência.

Também, com relação à estruturação do pensamento científico e da forma como ele foi sendo construído, podem ser citados alguns dados diretamente ligados às observações sobre o conhecimento que os índios Guarani possuem até hoje, e que passaram a ser fundamentais quando se 
preparavam as bases que sustentariam a questão do binômio na nomenclatura científica.

Segundo Storni (1944), o sueco Carl von Linné quando se referiu aos índios Guarani, o fez chamando-os de primus verus systematicus na biologia, devido à maneira com que esses índios classificavam e detalhavam ordenadamente a descrição e a diferenciação dos vegetais. A pesquisadora Giannini (1995), refere-se a essa mesma citação, perguntando se Linné teria criado os princípios da sistematização ou taxonomia, “(...) ou teria ele comprovado a existência de taxonomias nativas pré-existentes aos seus estudos (...)". Na verdade a autora chama a atenção para os créditos da contribuição intelectual que os Guarani prestaram à ciência, “... por cuja a criação Lineu é reconhecido". Noelli (1993), refere-se à classificação que os Guarani apresentam, não apenas sobre os vegetais, mas também e, inclusive, das "comunidades vegetais". O autor sustenta a seguinte formulação: "os Guarani também possuíam um sistema específico próprio para nomear as fisionomias vegetais e a geomorfologia dos seus domínios".

Pode-se considerar que muito do conhecimento considerado não científico é que fundamentou e formulou a base para que a ciência se estruturasse, o que pressupõe que as bases epistemológicas características das verdades científicas não são necessariamente científicas.

\section{6 o conhecimento indígena! A quem nos referimos?}

O fato do conhecimento indígena, ou o conhecimento dos indígenas ser uma reunião de conjuntos ordenados e complexos de regras, ações e idéias, integrados às crenças e práticas relacionadas entre si e que funcionam como uma estrutura organizada, porém não definitiva, implica em afirmar que, para cada indivíduo, em sua gênesis, ele está em constante modificação e adaptação, como será discutido no decorrer deste tópico.

O conhecimento dos indígenas, não obstante tantas definições que Ihe possam atribuir pesquisadores, governos, entidades civis, movimentos 
sociais e ambientalistas e as próprias lideranças indígenas, não está sendo examinado aqui para encerrar a discussão sobre sua definição ou seu papel.

Não se pretende criar uma nova constelação de dicotomias que possam auferir a este trabalho o título de inovador na (re)elaboração conceitual do conhecimento, ou muito menos, de conhecimento indígena. No entanto pode-se concordar com Ellen \& Harris (1996), que afirmam que o conhecimento indígena é local e está arraigado a um lugar em particular, sendo gerado por pessoas que vivem nesse lugar. Esse conhecimento é transmitido oralmente ou por imitação e demonstração e é a conseqüência de um compromisso prático na vida cotidiana onde essa experiência se caracteriza como o produto de muitas gerações de raciocínio inteligente, sendo que seu sucesso e fracasso representam a própria "evolução" no sentido de selecionar o modo operante de vida, bem resumido por Hunn (1993), quando afirma que tal conhecimento "... é testado no rigoroso laboratório da sobrevivência".

Assim, o conhecimento indígena permanece em constante mudança e adaptação, e sua sobrevivência depende exatamente de sua (re)elaboração concomitante à transmissão, caracterizando-se pela historicidade e temporalidade. Isto é, está vinculado à realidade local, no tempo e espaço, precedendo da contínua construção de sua transmissão entre gerações, sendo elaborado e re-elaborado a partir de experiências presentes e do entendimento da reordenação de mudanças continuadas dos significados que se apresentam "dialogando" insistentemente entre si. A distribuição desse conhecimento, ao contrário do que se imagina, não é simétrica e constante. Ela ocorre em uma população através de muitos fatores como gênero e idade, sendo que sua apresentação numa fragmentação corolária, no sentido de que se submete a partir das proposições que são entendidas, aceitas e transmitidas, a partir de outras demonstradas, é decorrência da própria existência. Essa própria distribuição do conhecimento é parte importante de seu corpus para atingir um entendimento simbólico e metafórico na cultura da etnia e apresentar-se coerente com as práticas e representações a que se submete. Assim, podem ser encontrados especialistas em determinados assuntos, enquanto na mesma 
etnia muitos indivíduos sequer conhecem pelo menos superficialmente o mesmo assunto, ou apenas possuem o senso comum a respeito dele.

Ellen \& Harris (1996) afirmam que o conhecimento indígena tem uma distribuição fragmentária, não existe em sua totalidade em um indivíduo, mas está condicionado às práticas interativas em que as pessoas, elas mesmas, se encaixem, e no caso de haver especialistas sua ocorrência se verifica "(...) em virtude da experiência, mas também em virtude de ritual ou autoridade política". Esses autores ainda se referem ao caráter essencialmente funcional desse conhecimento, contrapondo-se à reivindicação de que existe uma cultura ampla realmente universal, de classificações abstratas de conhecimento baseados em critérios não funcionais como propõem Berlin (1992) e Atran (1990).

Segundo Slikkerveer (1999), a prática de se estudar formas para entender os sistemas de conhecimento indígena se torna muito difícil, principalmente por que se tem como metodologia sempre compará-los com outras formas de conhecimento como, o sistema de conhecimento global ou mundializado (conhecimento científico). Essa comparação muitas vezes busca encontrar o equilíbrio entre o êmico e o ético, por meio de uma prática que é chamada de cognição comparada (Marques, 2001), onde o pesquisador usa do artifício de comparar os dados êmicos abstraídos em suas pesquisas com os dados científicos da literatura científica (dados tidos como éticos). Se as comparações são realizadas com o intuito de complementar, ao invés de julgar se um deles anula o outro, então o uso desse modelo é interessante para o estudo do conhecimento, pois poderá levar ao entendimento pormenorizado do conhecimento local e complementar tanto o conhecimento científico como o não científico.

O que se tem notado é que as dificuldades se tornam ainda mais perceptíveis à medida que o conhecimento indígena começa a ser encarado como uma das chaves para um desenvolvimento sustentável, e nesse sentido, passa a ser visto como uma panacéia para os problemas ambientais do mundo 
não indígena. Como os conhecimentos ocorrem em lógicas diferentes, não se pode formatar um modelo de desenvolvimento a partir de fragmentos observados de uma determinada cultura, mesmo por não ser indicado analisar tudo sob uma única lógica quando a observação se refere a eventos que ocorrem em diferentes lógicas. Por isso a comparação deve ser complementar e não finalizar uma questão.

A ciência parece ter muita pressa em estudar e catalogar esse conhecimento e muitas vezes não tem tomado os devidos cuidados na construção de sua teorização. As metodologias e os anseios envolvidos na busca de entender o conhecimento indígena com os objetivos voltados principalmente para finalidades utilitaristas que culminam com seu emprego na industria e comércio pode, decisivamente, interromper o fluxo natural de sua transmissão apontando para a descaracterização desse conhecimento.

A civilização tecnológica apressa-se em encontrar meios para escolarizar os índios, implantando como forma de transmissão do conhecimento a transferência da sabedoria do "profissional de ensino", realizada a partir do conhecimento escolarizado num modelo de transmissão estranho aos costumes, como se tal procedimento pudesse substituir a transmissão que ocorria através da coerência de raciocínios conjuntos, marcados por características humanas participativas e que envolviam o aprendiz com o seu meio. Essas características podem criar, preservar, aprimorar e modificar-se, através da comunicação entre os indivíduos envolvendo uma visão cosmogônica e cosmológica, adquirida desde o nascimento até a morte, sendo inclusive, determinante cultural para a base de interações sociais entre os viventes de uma etnia.

Muitas análises realizadas por disciplinas extremamente limitadas em sua perspectiva de entendimento do saber, que não têm em seu escopo o objetivo de tal entendimento, acabam por fazê-lo, porém realizam um exame superficial, mas expressam uma análise conclusiva. Taticamente ao analisar o conhecimento do outro, superficialmente, o fazem apenas para considerá-lo 
insuficiente diante das categorias convencionais da metodologia científica para não ficar caracterizado o limite da própria pesquisa ou da metodologia empregada, o que a tornaria inviável, revelando a sua inadequabilidade.

Para ilustrar tais afirmações, pode-se citar a abordagem realizada por Geertz (1999). Para o autor, a questão do "credenciamento científico" se apropria de um julgamento que tenta desqualificar os outros saberes estigmatizados como do senso comum, enfatiza a questão do intuito focalizado em dizer "que somos todos iguais no campo", enquanto o "outro igual" é na verdade o objeto de estudo do pesquisador que, mesmo tendo como característica o fato de estar indo ao campo para aprender com o outro, não é comum e portanto é um "igual superior". Geertz (op. cit.) considera que:

\begin{abstract}
"o pensamento é múltiplo como produto e singular como processo, o que se constitui como importante paradoxo nas ciências sociais gerando teorias em todas as direções, algumas delas razoáveis, mas a natureza do paradoxo tem sido vista como relacionada com um quebra-cabeça de tradução, ou seja, o de como o significado num sistema de expressão é expresso em outro"
\end{abstract}

Verificando que o exame da natureza ideológica e do saber local exige atenta observação ao contexto histórico em que o saber se opera (Biersack, 1995), metodologias antropológicas mais abrangentes podem auxiliar na construção de uma interpretação que não descaracterize o objeto de estudo demarcando, com uma linha imaginária seus limites.

$\mathrm{Na}$ realidade, o limite já é imediatamente determinado pelo próprio pesquisador à medida que está usando uma metodologia, seja ela qual for, pois a base epistemológica que fundamenta o conhecimento do pesquisador é elaborada a partir de certos constituintes tais como: ética e moral social da sociedade em que vive, formação da linha de orientação de seu próprio 
conhecimento, entre muitos outros atributos que o caracterizam em sua essência e o colocam em um mundo com o qual ele tem mais afinidades.

Neste sentido, o estudo do conhecimento (seja ele qual for) deve apresentar uma perspectiva interdisciplinar, isto é, que permita um diálogo entre diversas disciplinas envolvendo o entrecruzamento de diferentes análises inclusive permitindo-se buscar o entendimento do universo em que está inserido o objeto estudado. Segundo Almeida (2001),

$$
\begin{aligned}
& \text { "(...) o exercício do diálogo entre disciplinas e áreas } \\
& \text { do conhecimento, pautado pela 'suspensão' dos } \\
& \text { pontos de vista individuais, como mecanismo } \\
& \text { facilitador para entender o outro discurso, é o ponto } \\
& \text { de partida para inaugurar outro horizonte do } \\
& \text { conhecimento, menos ossificado, mais flexível e } \\
& \text { ampliável." }
\end{aligned}
$$

\subsection{Uma resposta metodológica que abrange várias disciplinas para se estudar o conhecimento indígena sobre os insetos}

A conceituação oferecida pela ciência ocidental para o termo "inseto" é elaborada agrupando essa forma de vida em uma divisão do reino animal, a classe Insecta. Através principalmente da caracterização morfológica, a taxonomia científica classifica e agrupa esses animais, de uma maneira geral, como sendo aqueles que possuem o corpo formado por segmentos, os quais se fundem em três partes distintas: cabeça, tórax e abdome, apresentam três pares de patas articuladas a partir do tórax e, geralmente, possuem antenas. A ciência denominou os especialistas que lidam com essa classe de animais como entomólogos. Verifica-se que os próprios entomólogos além dos insetos, estudam outros animais com certas características semelhantes 
agrupadas no filo Arthropoda ${ }^{13}$, que reúne em sua divisão várias classes diferentes: Arachnida; Crustacea; Chilopoda e Diplopoda, além dos Insecta (Barnes, 1990).

Segundo Posey (1983), "as categorias cognitivas, tais como insetos ou outros artrópodes, não podem ser presumidas como universais". Nos casos dessas categorias, sugere que o estudo deva obedecer ao uso de outra metodologia "preferencialmente que 'descubra' paradigmas conceituais ao invés de impô-los à sociedade em estudo".

A abordagem metodológica para 0 entendimento sobre 0 conhecimento de outro saber envolve o pressuposto de um (re)conhecimento anterior da sabedoria do outro o que, segundo D'Olne Campos (2002), nem sempre acontece, principalmente em se tratando de um interlocutor que é visto apenas como um mero informante. A possibilidade de entendimento da outra sabedoria exige do pesquisador cuidados especiais sobre a conduta metodológica além do tratamento que será dado às interpretações do material colhido.

A investigação do conhecimento pode obedecer a duas abordagens metodológicas que se distinguem, principalmente, pela maneira na qual são registradas as informações: a abordagem êmica e a abordagem ética ${ }^{14}$. Elas surgiram, segundo Costa-Neto (2002), numa tentativa de separar as interpretações culturais do pesquisador das informações fornecidas pelo pesquisado.

13 Filo de animais enterozoários de simetria bilateral, cujo corpo é revestido de esqueleto quitinoso dividido em cabeça, tórax e abdome, com quatro ou mais pares de apêndices (patas e antenas), quase sempre articulados. Tubo digestivo completo; respiração por meio de traquéias, pulmões ou brânquias; sexos geralmente separados. Terrestres ou aquáticos, de vida livre, comensais ou parasitas.

14 Essa terminologia tem provocado muitos mau entendidos (D'olne Campos,1994) e tem normalmente sido substituída pelo que pode ser considerado como "mesmo termo" que são as expressões "insider" e "outsider" que, na explicação de Roué (1997) significa expressar a "visão interna" e a "visão externa" respectivamente. É importante salientar que esses termos também são usados como "o pensamento do outro" ou "a visão do outro" para "insider", e "a interpretação do pesquisador" ou "a explicação científica", para o termo "outsider". 
Tais termos foram formulados por Kenneth Pike, pesquisador lingüista norte americano que, ao longo de suas pesquisas, desenvolvidas desde 1935, tinha como objetivo a descrição de dados empíricos, especialmente os dados colhidos no campo, em uma pesquisa sobre o idioma Mixtec, da etnia Mazatec do México. Em 1954, Pike cunhou os termos "emico" e "ético" para explicar as aproximações que existiam entre idioma e cultura. A intenção talvez fosse a de estabelecer um parâmetro mais resumido às explicações sobre o entendimento que o "outro" (entrevistado, informante ou mesmo observado), possui a respeito do mundo exterior a partir de sua formulação própria, independente dos dados científicos e da provação científica. Para tal explicação Kenneth Pike usou o termo "êmico", referindo-se ao que o pesquisador abstraia do entendimento do seu pesquisado na interpretação do próprio pesquisado.

Para se referir à interpretação do pesquisador (entrevistador ou observador), a qual se caracteriza pelo fundamento científico, ou seja, os dados são observados e interpretados a partir do conhecimento científico e suas metodologias, ele usou o termo "ético". Segundo Headland (1990), o que deveria ser apenas uma forma condensada ou simplificada para explicar o mesmo evento, observado por dois atores diferentes, adquiriu uma grande proeminência, passando a servir como tema de diversos debates no mundo acadêmico.

Em síntese, uma abordagem êmica é aquela na qual o pesquisador tenta subjetivamente observar o mundo de um indivíduo através dos olhos do próprio indivíduo (Kormondy \& Brown, 2002). É uma tentativa de descobrir e descrever o sistema comportamental de uma dada cultura nos seus próprios termos, identificando além das unidades estruturais, as classes estruturais às quais elas pertencem (D'olne Campos, 2002). Por intermédio dessa abordagem o pesquisador tem a possibilidade de estudar os mais minuciosos detalhes que sejam objetos de seu trabalho, por "intermédio dos olhos e pensamentos do pesquisado" sem restringir a coleta de dados aos preceitos e (pré)conceituação já estabelecidos em sua formação. 
Quanto à abordagem ética ela se compõe de categorias e valores "do observador", pré-estabelecidos pela ciência, utilizados na descrição e análise por ele realizadas e que não correspondem, necessariamente, àqueles que vigoram na sociedade ou cultura em estudo ${ }^{15}$. Enquanto a abordagem ética é conceitualmente lapidada antes do conhecimento da outra forma de entendimento do saber, podendo ser considerada a mais convencional e que o pesquisador conhece previamente, independentemente do universo da etnia que será estudada, a abordagem êmica baseia-se no entendimento dos valores daquela cultura em especial, no "desarmamento" do pesquisador, permitindose à abertura para novos conceitos e que, para a sua existência, não dependem dos conceitos científicos ${ }^{16}$.

\subsection{A interdisciplinaridade na etnobiologia}

A pesquisa desenvolvida a partir de uma visão interdisciplinar, portanto mais abrangente, possibilita ao pesquisador estabelecer metodologicamente um entrecruzamento entre diversos ramos da ciência. Neste caso implica numa interconexão conjuntural entre o biológico e o antropológico, permitindo ampliar o espectro de compreensão da realidade do conhecimento que se está pesquisando. Tal preceito reconhece a afirmação de Posey (1986a), explicando que a etnobiologia objetiva integrar diferentes subsetores das Ciências Sociais e Biológicas com outros sistemas científicos, servindo para mediar diferentes culturas provendo um arcabouço teórico para firmar essa integração.

A etnobiologia é vista como uma disciplina que inclui várias subdisciplinas (etnobotânica, etnoecologia, etnoentomologia, etnoictiologia, etnozoologia,...) e, segundo Berlin (1992), foi o termo usado por Clastetter em

15 A pesquisa cognitiva, "êmica", não se anula ou se sobrepõe a métodos de abordagem "ética". Os estudos de transmissão de doenças, contaminação de alimentos, insetos como alimentação, insetos alucinógenos, etc, podem, segundo Posey (1987), ser conduzidos com metodologias "éticas" sem que isso diminua sua importância e contribuição para as etnociências, que são exeqüíveis em países que possuem grupos humanos herdeiros de culturas pré-históricas, como é o caso do Brasil (Ab'Sáber, 2002).

16 Para um entendimento mais profundo de Êmico e Étco, sua história e significado ver Harris (1976) e Berreman (1966). 
1935, como o estudo da utilização da flora e fauna pelos povos primitivos. Atualmente 0 debate sobre uma definição conceitual para o termo "etnobiologia" tem ocupado espaço nos bancos acadêmicos. No entanto uma definição muito aceita propõe que:

\begin{abstract}
"A etnobiologia é essencialmente o estudo do conhecimento e das conceituações desenvolvidas por qualquer sociedade a respeito da biologia. Em outras palavras é o estudo do papel da natureza no sistema de crenças e adaptação do homem a determinados ambientes. Neste sentido a etnobiologia relaciona-se com a ecologia humana, mas enfatiza as categorias e conceitos cognitivos utilizados pelos povos em estudo" (Posey, 1986a, p.15)
\end{abstract}

Segundo Clément (1998b), existem três fases que caracterizam historicamente a fundamentação e construção científica da etnobiologia como disciplina: a fase pré-clássica, caracterizada pelos fundamentos da disciplina, pela determinação e definição de vários ramos, iniciada em 1860 e terminada na década de 1950, quando os pesquisadores centraram seus estudos no aspecto cognitivo. A fase clássica, que a sucedeu, durou até a década de 1980. Nesse período, eram enfatizadas as etnotaxonomias e as análises etnosemânticas. A fase atual, considerada pelo autor como a fase pósclássica, na qual a investigação está sendo centrada em várias áreas: etnoclassificações, manejo participativo dos recursos naturais, processos de domesticação de plantas e animais, cosmovisão, movimentos pelos direitos de propriedade intelectual, entre outras. Não obstante, Clément (op. cit), afirma que a origem da etnobiologia remonta aos tempos em que os primeiros hominídeos se interessaram por plantas e animais. 


\subsection{A etnoentomologia (...percepção...interação...relação...)}

Os entomologos-filósofos ${ }^{17}$ além de descreverem os fenômenos entomológicos, segundo Hogue ${ }^{18}$ citado por Posey, (1987), “... escreveram e falaram de seu significado num plano intelectual humano", ao que Posey (1987) aponta como indicativo de que a moderna entomologia teria adquirido características humanísticas de onde viriam suas tendências "etno". Para Hogue (1987), o termo "entomologia cultural" é usado na indicação dos estudos de influência dos insetos sobre a "essência de humanidade tal como expressamos nas artes e humanidades". Entretanto, de acordo com Posey (1987), os entomólogos culturais tentam restringir seus estudos às sociedades "avançadas", industrializadas e instruídas, sustentando que fatores entomológicos de sociedades "primitivas" ou "não-civilizadas" são da competência dos etnoentomólogos.

Diante dessa visão, Posey (1987), chama a atenção para o preconceito etnocêntrico do "nós e eles", uma visão artificial sobre sociedades "civilizadas" e as sociedades "primitivas", afirmando que "tais ilações não foram consubstanciadas pela pesquisa antropológica". Overal (1990), reforça a tese de que tanto as sociedades "avançadas" como as tradicionais possuem elementos que por suas características podem ser ambas estudadas pela etnozoologia e, em qualquer caso, o estudo pode começar na sociedade a que se pertence ${ }^{19}$. É evidente que se pode dizer o mesmo para a etnoentomologia.

Pode-se afirmar que o começo da etnoentomologia contemporânea, que Clément (1998b) preceituou como sendo a fase clássica da Etnobiologia,

17 William Morton Wheeler, Maurice Maeterlink, Jean Henri Fabre.

18 HOGUE, C. Commentaries in cultural enthomology. 1. Definitions of cultural enthomology. Enthomological News, v.91, n.2, p.33-36. 1980.

19 But what of ourselves? Are we not exotic as well? The very word "exotic"admits two meanings: both geographical remoteness and unfamiliar, strange or quaint encountersca give you exotic. My suggestion, here belabored, is that our own society, while not indigenous or even folk, has elements of both and that the study of ethnozoology can begin at home. Our multifaceted relationship with animals is an evolved one, inherited by us from diverse sources. It is time to lookthe gift horse in the mouth. (Overal, 1990). 
ocorreu no século XIX, com os estudos que diversos autores ${ }^{20}$ desenvolveram sobre a interação das sociedades humanas com os artrópodes, relacionando sua nomenclatura em diversas etnias. Segundo Posey (1987), outros trabalhos ${ }^{21}$ trouxeram o assunto para o século $X X$, tendo sido os estudos de Essig (1934), sobre a importância dos insetos para os índios da Califórnia (The value of insects to the Califórnia Indians) que instituíram as categorias tradicionais de interesse etnoentomológico. No entanto, foram Wyman \& Bailey (1952) os primeiros a fazer uso do termo etnoentomologia numa publicação científica: Native Navajo methods for the control of insect pests. Os mesmos autores, em 1964, lançaram o primeiro título de livro com o termo etnoentomologia: Navajo indian ethnoentomology.

A definição da etnoentomologia envolve mais que uma simples análise de dois componentes "etno" + "entomo...", como veremos a seguir. No entanto, o presente trabalho não se propõe à difícil tarefa de definir ou redefinir, ou ainda, conceituar, esse termo. Assim alguns autores foram considerados.

Estudos relacionados aos insetos em interação com a cultura humana ou sua recíproca, fazem parte do universo abarcado pela etnobiologia, mais especificamente um dos ramos que a compõe, a etnoentomologia, que segundo D'Olne Campos ${ }^{22}$, citado por Costa-Neto (2000), examina o conhecimento entomológico de uma dada etnia, tendo como base os parâmetros da ciência ocidental. Para todas as definições encontradas sobressaíram conceitos como a percepção do conhecimento entomológico em diferentes culturas humanas (Posey, 1987), a interação e inter-relação entre sociedade humana/insetos (Berlin, 1992) e a relação da humanidade/entomofauna em várias dimensões das ciências (Berón, 2000).

20 Bates (1862), Daoust (1858), Glock (1891), Hagan (1863), Katter (1883), Liebtrecht (1886), Marshall (1894), Wagner (1885) e Wallace (1852).

21 Knortz (1910), Skinner (1910), Ealand (1929) Caudell (1916), Arndt (1923), Barret (1925), Gudger (1925), Laufer (1927), Dammerman (1929) e Nordensiöld (1929). As referências completas citadas nesta nota e na anterior podem ser conferidas em Posey, 1987.

22 D'olne Campos, M. Fazer o tempo e o tempo do fazer: ritmos em concorrência entre o ser humano e a natureza. Ciência e Ambiente. Santa Maria: v.8, p.7-33. 1994. 
Neste estudo adotou-se a seguinte definição: etnoentomologia é o campo da pesquisa metodológica que, ao examinar o conhecimento, pensamentos, crenças, sentimentos, práticas, utilidades, interações e interrelações entre o homem, as sociedades humanas e os insetos, constitui uma ponte entre os saberes local e o estabelecido pelas Ciências, descobrindo paradigmas conceituais, enfatizando as categorias e conceitos cognitivos utilizados pela sociedade em estudo, não os condicionando aos preceitos préestabelecidos e apresentando-se como uma possibilidade interdisciplinar para proporcionar uma visão mais ampla do objeto de estudo.

\subsection{Dificuldades básicas encontradas com a pesquisa etnoentomológica}

A metodologia sugerida para que se estude a questão do conhecimento dos insetos por indígenas ou outras populações, compartilha de uma abordagem que questiona os objetivos e caminhos que podem ser seguidos. Dificuldades no percurso da pesquisa podem estabelecer conflitos entre os interesses iniciais do pesquisador e a ética em seus trabalhos. Não é diferente com outras metodologias, mas algumas advertências sobre 0 questionamento das dificuldades que são encontradas podem auxiliar o pesquisador nos quesitos básicos para o desenvolvimento da pesquisa etnoentomológica.

Costa-Neto (2002) discorre sobre as dificuldades encontradas para que se realize um estudo etnoentomológico. Afirma que há pelo menos três dificuldades quando se pretende desenvolver um estudo etnoentomológico e que elas são intrínsecas e extrínsecas ao pesquisador. A primeira se apresenta como um preconceito da ciência ocidental que, de um modo geral, cria diversas barreiras para aceitar as etnociências. Tradicionalmente, a ciência treinou os cientistas para se considerarem os únicos capazes de descrever o universo e de dar a ele um sentido lógico. Essa é a perspectiva que aponta para que a ciência ocidental julgue qualquer hipótese ou interpretação elaborada fora de suas próprias regras de preceitos e que fuja de sua estrita objetividade, como 
sendo considerada muito duvidosa e quase que totalmente banida dos meios acadêmicos.

A segunda dificuldade, notadamente importante, é a questão que trata da excessiva especialização dos biólogos e cientistas sociais. Normalmente os cientistas sociais não recebem o devido treinamento que os capacite para trabalhar com informações das ciências biológicas. O inverso também é constatado, sendo que muitos biólogos consideram os dados das ciências sociais como de pouca ou nenhuma importância para os seus estudos e raramente levam em consideração os fatores culturais, entre os quais os costumes, a cosmogonia e a cosmologia de uma dada comunidade, não se preocupando com dados históricos e mesmo, atuais, dos sistemas ecológicos.

A terceira dificuldade diz respeito ao etnocentrismo que, como se sabe, conceitualmente é uma visão de mundo onde um grupo se considera o centro de todos os outros, em que a tendência é considerar as categorias, normas e valores da própria sociedade, neste caso da ciência ocidental, os únicos parâmetros verdadeiros e testáveis, enquanto os outros não são verdadeiros e, tradicionalmente, são considerados errados, falsos ou de menor valor.

As dificuldades ou etapas a serem ultrapassadas para a realização de um estudo com as sociedades humanas e seu conhecimento sobre insetos, objeto da etnobiologia e mais especificamente da etnoentomologia, segundo Posey (1986a), apontam para a necessidade de um treinamento teóricometodológico que não se restrinja apenas a uma única área da ciência tradicional como as ciências humanas ou as ciências biológicas. Na medida que o pesquisador detém conhecimento a respeito dos hábitos e costumes da etnia a ser estudada, terá uma compreensão mais clara dos valores intrínsecos e extrínsecos que formam o conhecimento a respeito dos insetos, e seu trabalho poderá ultrapassar o limite de inventariar nomes e usos dos animais pelos nativos. 
Encontros científicos de abrangência internacional surgem rompendo uma barreira esperada por vários grupos de pesquisa. O primeiro congresso organizado exclusivamente para reunir pesquisadores e estudantes da interação humanos/insetos foi realizado em 2002, em Paris ${ }^{23}$. As dificuldades encontradas para os estudos disciplinares das etnociências começam a ser ultrapassadas com mais popularidade nos meios acadêmicos e, atualmente, existem vários grupos de pesquisadores desenvolvendo trabalhos de etnociência em diversas universidades por todo o Brasil, gerando encontros estaduais, regionais e nacionais. Embora os estudos e as titulações nessa área ainda sejam novidade, no nível da pós-graduação começam a aparecer muitos interessados, o que aponta para o desenvolvimento de linhas de pesquisa que no futuro proverão cursos, formando uma massa crítica nas universidades.

\subsection{0 que se deve considerar para pesquisar em etnobiologia e disciplinas correlatas?}

As pesquisas que tratam em seus objetivos da correlação de inventários e uso de animais, abrangendo além de sua utilização como produto de consumo do cotidiano, buscam, além disso, as conceituações simbólicas e metafóricas, representadas nas expressões internas, vividas pela cosmogonia e cosmologia de outras realidades. Tais expressões, ao se inter-relacionarem objetiva e subjetivamente, não se permitem metodologicamente às restrições da sociodiversidade ou contextualmente às restrições da socioculturalidade. Além de interdisciplinar, essas pesquisas se propõem à integração entre saberes. Apresentam-se, objetivando exatamente não serem excludentes, podendo tratar dos sistemas biológicos correlacionados aos "simbólicos e metafóricos", ocupando-se de maneira heurística de temas considerados estranhos aos paradigmas tradicionais, e talvez insuficientes tanto apenas para a Biologia como para a Antropologia.

A etnobiologia na produção do conhecimento científico caracterizase como uma ponte entre as ciências humanas e as ciências biológicas e vice-

23 Simpósio Internacional "Os Insetos na literatura oral e tradicional" - Paris, França, reuniu mais de 60 pesquisadores e foram apresentados 42 trabalhos. 
versa, fornecendo ferramentas essenciais para a interdisciplinaridade entre ambas e proporcionando ao pesquisador desenvolver um trabalho mais profundo e abrangente, testando hipóteses que dificilmente seriam elaboradas sem uma metodologia interdisciplinar. A conceituação epistemológica, neste caso, resulta da recusa de interpretações reducionistas. Para se estudar um assunto por meio das Etnociências, como a etnobiologia, é indispensável o reconhecimento de que não há divergências entre as diversas linhas de pesquisa, mas sim que existe uma complementaridade entre elas e que a ciência não é "monolítica" e acabada, bem como o conhecimento e o saber não são estanques, ou exclusivos de um determinado grupo. Geertz (1999) usou uma metáfrase que pode ser citada para a identificação desse grupo, identificando-o como o grupo dos possuidores do "credenciamento científico".

Deve-se considerar que tanto a metodologia da ciência ocidental formal e acadêmica, como quaisquer outras formas de conhecimento e sabedoria, não detém a verdade absoluta para se compreender os conhecimentos que uma etnia possui sobre a natureza ou a inter-relação do homem com a natureza, incluindo-se aí todas as formas de vida. No entanto, metodologias diferentes se complementam e se constituem em ferramentas de auxílio para o crescimento desta compreensão.

Um grande cuidado deve ser tomado para que tais metodologias não apontem para uma unificação do conhecimento. A atividade de "registrar o conhecimento indígena", por exemplo, pode isolar e fragmentar a sabedoria desconstruindo sua gênese e compartimentalizando suas especificidades, desconsiderando os fatores simbólicos e metafóricos que, se não são considerados, implicam em caracterizar o sistema de conhecimento como estando fora da cultura, visto apenas como um satélite na esfera cultural.

Na medida em que a ciência ocidental se apossa do conhecimento indígena, pinçando fragmentos de seu empirismo, simbolismo, espiritualismo, e se volta para a mercantilização dos dados, contribui para a desconstrução desse conhecimento, principalmente por analisar fragmentos, tentando juntar 
suas partes para formar um mosaico aceitável aos parâmetros culturais do próprio pesquisador, que é coroado com a difusão universal e a materialização dos dados num complexo meio de eternizar os pensamentos, que é a escrita.

É necessário que a pesquisa científica não assuma o caráter de globalização e universalização das culturas e das práticas de seus conhecimentos, pois as especificidades que as diferenciam troponomicamente, isto é, as mudanças adquiridas segundo diferentes tempos e lugares, é que as igualam subjetivamente e as estabelecem reconhecendo-as como "o outro conhecimento". 


\section{OS GUARANI}

\subsection{Introdução}

Escrever sobre os índios Guarani parece ser uma tarefa fácil quando analisados alguns fatores, quais sejam, 1) talvez em toda literatura sobre índios do Brasil, aquela que apresenta a maior quantidade e diversidade de autores é referente aos Guarani; 2) os índios Guarani ainda vivem até o presente e estão "espalhados" pelo centro-oeste, sudeste, e sul do Brasil, abrangendo praticamente metade do país, além de serem facilmente encontrados nos países limítrofes; 3) boa parte do vocabulário atual é composto de palavras do tronco lingüístico tupi-guarani, chegando em alguns estados cerca de $40 \%$.

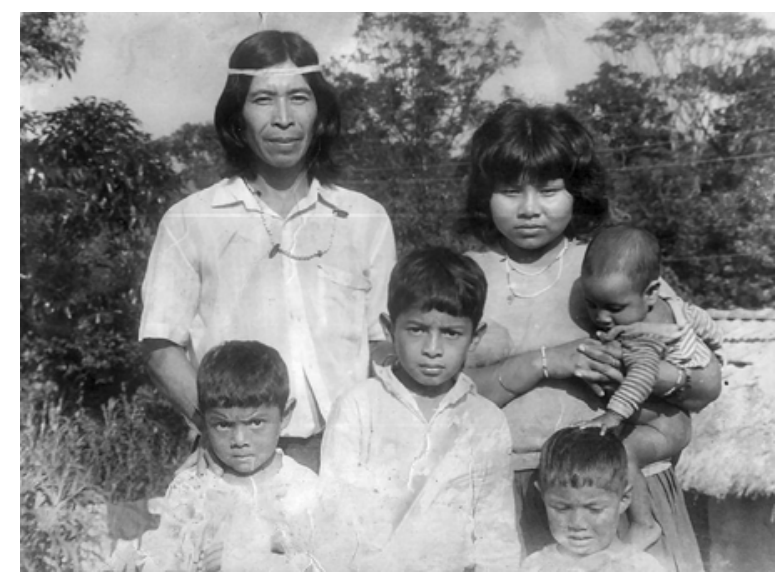

Figura 1 - Karai Poty, esposa e sobrinhos (1989), ao fundo vê-se parte de sua moradia, onde hoje é a entrada da aldeia 
$\mathrm{Na}$ verdade, se alguém se dispuser a continuar a enumeração dos fatores que hipoteticamente atribuem facilidades para a tarefa de escrever sobre os Guarani, certamente encontrará muitas justificativas, tantas que convenceriam qualquer inexperiente a aceitar a hipótese de que escrever sobre esses índios ou sobre a etnia Guarani é fácil. No entanto a realidade se mostra completamente diferente. A literatura apresenta diversas interpretações e, muitas vezes, o mesmo autor, em diferentes épocas, retorna a um assunto desenvolvendo-o de maneira que praticamente cria uma nova interpretação ou chega mesmo a redefinir os trabalhos anteriores. Além do mais, os Guarani estão vivos, sua cultura está viva e, na verdade, ainda se tem muito para aprender com eles.

Neste capítulo é apresentado um breve apanhado sobre os Guarani, realizando, principalmente, uma epítome dos séculos XVI e XVII, período de contato com os colonizadores da América Latina e que causou um grande impacto para todos os povos que habitavam, ou que ainda habitam o continente. É nesse curto período de tempo que estão concentradas as maiores evidências que muitos autores consideram como fatores decisivos sobre o que sucedeu posteriormente com os Guarani e sua cultura.

O presente capítulo pretende criar uma condição mais adequada para se entender a complexidade do conhecimento e as formas que os Guarani foram obrigados a encontrar para manter a transmissão de sua sabedoria e tradições, que passam oralmente dos mais velhos para os mais novos.

O capítulo se encerra apresentando um apanhado geral sobre os habitantes da Aldeia Morro da Saudade, onde se desenvolveu quase que totalmente a coleta de dados referenciais para este estudo.

\subsection{O início da desconstrução da história dos Guarani}

Durante os séculos XVI e XVII, segundo Monteiro (1992), várias populações indígenas de diversas etnias sentiram o forte impacto da conquista 
espanhola na bacia do Prata, dos padres franciscanos e dos jesuítas, além dos portugueses das capitanias do sul do Brasil, que travaram uma árdua e incansável busca de cativos para o desenvolvimento do comércio e da agricultura.

Estudos históricos abrangendo várias etnias apresentam dados que evidenciam a influência direta ou indireta sobre a demografia e a distribuição dos povos indígenas por toda a região anteriormente mencionada. No entanto, não há duvidas de que a etnia que mais sofreu com as práticas políticas impostas pelos europeus colonizadores foi a etnia Guarani. A historiografia, na maioria das vezes, apresenta os Guarani como índios dóceis e obedientes servos dos jesuítas, principalmente quando a referência são os livros didáticos do ensino básico e médio. Também são vistos ora como elementos participantes das bandeiras ou, até mesmo, como enteados em alguns casos. Mas em quaisquer dessas situações são sempre descritos como vítimas do sanguinário conquistador, o que não deixa de ser verdade.

Essa visão historiografada sobre os Guarani os apresenta como inertes e mudos na condição de construtores de sua própria história. $\mathrm{Na}$ realidade, contradizendo esse estigma, os Guarani ao longo de sua existência pós-europeização do Brasil, desenvolveram estratégias que fundamentaram mais que uma simples sobrevivência. Na verdade, alicerçaram, ao longo do tempo, em condições invariavelmente adversas, formas de recriar a sua identidade e manter o seu modo de ser, mesmo que até certo ponto modificado (adaptado), conservando valores étnicos importantes como, o idioma e o sentimento religioso. Nos estudos realizados até o presente, tanto na historicidade como na etnograficidade, o que se apresenta com um importante destaque bibliográfico são as manifestações de religiosidade, que nos Guarani são reconhecidas como um modo de ser e que estão presentes em, praticamente, toda a literatura. Para alguns autores (Cadogan, 1959; Clastres, H. 1978; Clastres, P. 1978, 1990; Melià, 1988; Métraux, 1979; Monteiro, 1992; Nimuendaju, 1954; 1987; Schaden, 1954), a religiosidade entre os Guarani é um ponto comum e unificador de sua cultura, orientando sua visão do mundo. 
Pode-se acrescentar ainda que essa religiosidade, provavelmente, foi o maior estímulo à sobrevivência desse povo e que até hoje tem um valor significativo para a sua cultura.

Os inúmeros trabalhos históricos e etnológicos a respeito dos Guarani ainda não responderam a um dos maiores desafios existentes para os estudiosos, que é o de saber como de fato se caracterizava essa etnia às vésperas da chegada dos europeus ao continente sul americano. Ao referenciar o trabalho de muitos autores como base confiável de estudos a respeito dos dados existentes sobre esses índios, Monteiro (1992), chama a atenção para a condição tendenciosa dos registros documentais da época:

"No que diz respeito à etnologia, o conhecimento
dos Guarani às vésperas da conquista e durante os
primeiros séculos de colonização apresenta um
instigante problema de método, uma vez que a
reconstituição dos aspectos, sociais políticos e
religiosos dessa população tem sido elaborada tanto
a partir de um registro documental (fragmentário e
tendencioso, diga-se de passagem), quanto a partir
de influências provenientes dos estudos
etnográficos realizados neste século".

Outro fato que pode ser considerado importante quando se estuda a história dos Guarani, é que tanto as observações históricas como as etnográficas, segundo Viveiros de Castro (1987), apresentam dois significados: por um lado, a etnografia tem completado as informações ausentes em fontes escritas, e por outro, as fontes históricas tem apontado para novas perspectivas sobre a cultura Guarani, referentes à demografia, à organização política, ao profetismo, aos movimentos espaciais de cunho religioso e mesmo à filosofia. 


\subsection{Quem eram e onde estavam os índios Guarani antes da invasão européia}

Existem diversas tentativas de explicar tanto a distribuição espacial como a demográfica dos grupos Guarani. Varias hipóteses são levantadas a respeito do número de indivíduos espalhados por uma imensa área que vai desde os atuais estados brasileiros do Rio Grande do Sul, Santa Catarina, Paraná, São Paulo, Mato Grosso do Sul, além dos países limítrofes ao sul como o Paraguai, Argentina e o Uruguai. Porém o grande desafio é exatamente encontrar a melhor fórmula para se propor uma estimativa de quantificação e distribuição espacial desses indígenas, uma vez que as fontes existentes são do início da colonização e, segundo Melià (1988), provêm de observações bastante dispersas no tempo e espaço.

Monteiro (1992) afirma que de qualquer modo o ponto inicial para se estabelecer números a esse respeito é o "tamanho original da população, ou seja, o número de indivíduos existentes às vésperas do contato, a partir do qual teria havido um inexorável processo de declínio".

De fato, a possibilidade de se ter um número aproximado, mas confiável, que determine uma população às vésperas da chegada dos europeus ao continente é um exercício que foi, e ainda está sendo praticado de diversas formas. Pesquisadores de várias áreas têm dado sua contribuição para que se chegue a essa cifra, sendo que muitas vezes são feitas comparações com populações atuais, levantamentos ecológicos, estudos do meio, projeções comparadas com outras etnias, estudos arqueológicos, entre tantos outros métodos e parece que as discussões nesse sentido irão continuar por muito tempo.

Existe um grande debate entre os estudiosos a respeito desses números e citando apenas duas projeções (talvez as mais discutidas e referenciadas pela literatura científica) pode-se perceber que existe pouca segurança quanto às mesmas. Hemming (1978) chega a um número considerado por especialistas como "muito baixo" apresentando a somatória de 
todos os grupos Guarani como sendo compostos por 258 mil indivíduos, na época da invasão européia, o que o próprio autor, na mesma obra, considera, segundo Monteiro (1992) "adivinhação pura". Já para Clastres, P. (1978), o número de indivíduos, para aquela, época estaria em torno de 1,5 milhão. $O$ autor se baseou em algumas observações testemunhais de Hans Standen para os Tupinambá sediados entre o Rio de Janeiro e São Vicente. Sua base metodológica era a de que cada aldeia abrangia um território circundante de aproximadamente $150 \mathrm{~km}^{2}$, e a média de 600 indivíduos por aldeia. Para ter concluído o número de 1,5 milhão de indivíduos, ele projetou para o território

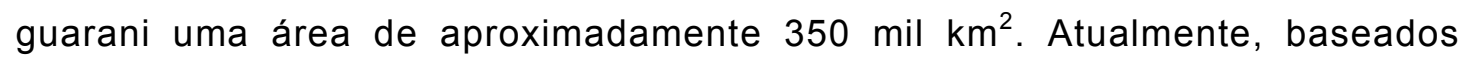
ainda em dados historiografados, os números apresentados por Clastres, $\mathrm{P}$. (op. cit.) são os mais aceitos com a ressalva de que o número exato pode ser maior que esse.

De qualquer maneira, o exercício de se tentar projetar um número para a população dos Guarani antes da invasão européia, esclarece pouco essa situação e leva a um outro número bastante discutido que é o de índios dizimados, isto é, independentemente do número de indivíduos que as pesquisas apresentam nos casos anteriores, elas apontam para uma conclusão: o declínio acentuado da população dos Guarani é reconhecidamente evidente após a chegada dos europeus ao continente sul americano. Sobre essa análise, segundo Monteiro (1992), corre-se o risco de apresentar a história desses índios como sendo a crônica de sua extinção, à medida que em qualquer base numérica da qual se possa partir, mesmo apontando para um número menor em análises mais pessimistas, o caminho decrescente dessa população é tão acentuado que estimula conclusões que se tornam óbvias diante da tentativa de explicar os Guarani como elemento de sua própria história.

Noelli (1993) chama a atenção para as pesquisas arqueológicas que sugerem que a partir da invasão européia as aldeias indígenas sofreram um processo de diminuição de seu tamanho e as populações se embrenharam cada vez mais para o interior, abandonando sistematicamente o litoral para 
garantirem suas vidas, procurando os locais que por suas características apresentavam-se com acesso difícil. O autor (op. cit.) sustenta a hipótese de que os Guarani

“ (...) reproduziram durante mais de 3.000 anos as mesmas características materiais de sua cultura, até as desestruturações e re-significações causadas pelo impacto das invasões européias nos séculos XVI e XVII" (Noelli, 1993)

Brochado ${ }^{24}$ citado por Noelli (1993), justifica tal afirmação apontando para o fato de que não se tenha notado qualquer modificação da cultura material não perecível, por exemplo, a cerâmica ou outros implementos líticos durante o período pré-europeu. Ou seja, tais artefatos quando encontrados, e identificados como pertencentes a diferentes épocas, anteriores à chegada dos europeus, apresentam-se sem que se verifiquem mudanças de padrão. As características geo-ecológicas também são uniformes, existindo evidências que apontam para modelos homogêneos de espacialidade em plantas de topo de estruturas arqueológicas. Outros fatores apresentados denotam significativa importância e podem comprovar o rigor da hipótese apresentada. Tais argumentos apontam para a questão lingüística em que mesmo se observando notórias modificações do século XVII em diante, dois aspectos importantes podem ser constatados: 1) rigidez lexical e 2) uma antigüidade deduzida quando realizadas comparações lingüísticas.

Mesmo sabendo-se que a literatura sobre essa etnia ocupa um grande espaço nas estantes das bibliotecas em pelo menos quatro países do sul da América Latina, acredita-se que, com os avanços da genética, poder-seá chegar a outros resultados científicos em breve. Essa metodologia da ciência ainda é pouco explorada para determinação dos dados expostos anteriormente. No entanto, poderá revolucionar categoricamente a pesquisa científica sobre as populações humanas em vários fatores, respondendo a muitas interrogações e 
esclarecendo dúvidas que hoje chegam a representar uma barreira na montagem do complicado quebra-cabeça sobre as civilizações antigas que habitavam ou habitam a América Latina.

\subsection{As lideranças e o aspecto carismático de condução organizacional Guarani}

Quanto à organização política e territorial dos Guarani, no que diz respeito às chefias políticas e lideranças dos profetas, sabe-se que importantes lideranças se revelaram no decorrer dos dois primeiros séculos da colonização européia sendo que a historiografia revela violentas batalhas contra os espanhóis e a não aceitação dos jesuítas pregadores, além das tensões que foram observadas contra os portugueses de São Paulo. Estes fatos anulam definitivamente a idéia de que os índios Guarani aceitavam passivamente o domínio ao qual estariam sendo submetidos, tirando-lhes o título de meros coadjuvantes de sua própria história.

A tentativa de explicar uma "homogeneidade" entre os Guarani é muito comum, geralmente apontando para resultados simplistas, colocando todos os índios que compõem a etnia no rol de um único grupo.

No entanto, as diversas alianças e conflitos apresentavam-se num cenário político muito complexo que abrangia, além da disputa entre os próprios Guarani, que vivenciavam cisões internas, um complicado relacionamento entre estes e outras sociedades indígenas, especialmente os Guaikuru e os Kaigang. As lideranças locais que se debatiam pelo poder no interior do grupo chegavam, invariavelmente, a disputas que fragilizavam esse relacionamento.

Discute-se a existência operacional de uma organização que levava em consideração lideres de vários grupos, talvez apontando para uma outra tentativa de homogeneização, desta vez explicada a partir do pensamento não mais do grupo, mas sim, apontando para uma interpretação que faça uma leitura da etnia por meio desses líderes. 
Muitas interrogações surgem sobre a existência ou não da instituição do cacicado entre os Guarani, e sobre essa estrutura tão citada e tão pouco discutida na historiografia, existem muitas interpretações e dúvidas. No entanto, sobre a questão das lideranças, uma das dúvidas é uma dualidade que sintetiza sua gênese: seriam essas lideranças emergentes, resultado das circunstâncias a que estavam submetidos os Guarani durante essa fase da conquista e colonização, que envolvia diretamente uma transformação da cultura e principalmente da distribuição espacial da etnia, ou, seriam compostas de caciques emergentes, num processo histórico autóctone e que, portanto, perderiam essa forma organizacional a partir exatamente da invasão do continente americano pelos europeus?

Sobre essas lideranças e suas influências na tradicional estrutura dos Guarani, Clastres, P. (1978) afirma que o desenvolvimento de chefias fortes estava presente quando da chegada dos europeus e que também por essa época teriam surgido os $k a r a i^{25}$, que contestavam essa autoridade. Sabese que os karaí eram proeminentes em suas falas e evocavam os heróis lendários em seus discursos proféticos e por intermédio desse artifício e de cantos e danças, persuadiram os índios a abandonar as aldeias em busca da "terra sem mal".

Clastres, H. (1978), aprofunda os estudos sobre os discurso dos karaí e apresenta uma hipótese onde afirma que a questão do profetismo entre os tupi-guarani, não era um movimento messiânico, “(...) pois proviria de conflitos e crises do interior da sociedade nativa e não - como querem outros autores - de fatores externos como as crises desencadeadas pela conquista (...)". Para a autora, a religiosidade dos índios se dava em torno da "terra sem mal" e era a orientação para suas vidas, independente do problema ocorrido com a chegada dos europeus.

25 Os "Karai" eram índios que contestavam frontalmente a autoridade do chefe, eram ótimos oradores, evocavam os mitos dos heróis civilizadores e da "terra sem mal". Por meio do discurso profético, cantos e danças e finalmente das migrações, convenciam os índios a abandonarem a aldeia e trocarem de liderança, indo em busca de um paraíso terrestre (Cf. Clastres, P. 1978). 
O uso da expressão "terra sem mal" apresenta uma série de discutidas interpretações, mas Melià (1988), questionando a historicidade conceitual do termo yvy marã ey (terra sem mal) busca na tradução dada pelo padre jesuíta Antonio Ruiz de Montoya ([1639] 1876) ${ }^{26}$ a maneira mais adequada para a expressão. Esse jesuíta apresenta yvy marã ey, como o "solo intacto, que não foi edificado", ou seja, "solo virgem". Melià (op. cit.), explica que existem grandes diferenças entre "solos intactos" dos séculos XVI e XVII, e "terra sem mal" dos séculos XIX e XX, ambas yvy marã ey. Para o autor existem dados suficientes para se acreditar que a procura de novas terras para as aldeias enquadra-se na idéia de espacialidade e, portanto essa procura era propícia ao se acreditar na "recriação de um modo de vida autenticamente Guarani, quer pela renovação do local de assentamento, quer pelo reencontro com uma terra mítica" (Melià, 1988).

Admitindo-se tal hipótese, é incontestável afirmar que a colonização significa o cerceamento da liberdade de movimento, restringindo a espacialidade geográfica dos Guarani, provocando uma ruptura na dimensão espacial de sua história. Portanto, a soma de todos esses fatores, segundo Monteiro (1984, 1992), resulta em considerar-se que a penetração colonial teria conferido uma grande credibilidade ao discurso de convulsão social (cataclísmico), favorecendo o desenvolvimento de estratégias migratórias e ameaçando a sobrevivência física e cultural dos Guarani.

Uma forma de se auferir mais conhecimentos a respeito das migrações pré-coloniais dos Guarani pode ser o estudo de suas relações com outras etnias da América do Sul. Existem importantes estudos que aprofundam a questão dos Guarani pré-colonizados, com minuciosos detalhes. Um dado curioso é levantado por Nordenskiöld (1917) ao realizar um estudo oferecendo elementos a respeito da invasão que grupos Guarani desferiram sobre os territórios do império Inca. Esse autor afirma que essas migrações parecem ter ocorrido por questões bélicas e pela busca de metais.

26 O jesuíta Antonio Ruiz de Montoya entre os anos de 1612 e 1617 elaborou o "Vocabulário e tezouro de la lengua Guarani", essa obra publicada em 1639 aborda com profundidade a relação linguagem cultura, relacionando o conhecimento dos Guarani 'a biologia. 
Retomando a questão das lideranças, pode-se afirmar que a "briga" entre tradicional e inovador existe em todas as sociedades. Mas neste caso, para tentar entender a história dos Gurarani tem-se que admitir a importância que o profetismo exerceu em sua construção, isto é, não se pode negar a importância do profetismo dessa etnia para a compreensão de sua história. Verifica-se que a ação do profetismo era, segundo Monteiro (1992), tanto tradicional como transformadora, e na explicação tanto de Schaden (1954), como de Melià (1988), procurava buscar a preservação dos dois elementos fundamentais para os Guarani: sua identidade e sua liberdade, portanto, era transformadora por pregar a destruição da ordem existente vislumbrando exatamente alcançar o primeiro objetivo.

\subsection{A sistematização da exploração sobre os índios}

Independente do formato que o movimento interno apresentava, o conflito entre liberdade e escravidão acentuava-se cada vez mais à medida que se concretizava a colonização. Enquanto os colonizadores iam se estabelecendo, também criavam novas estruturas de exploração das etnias existentes e com essa perspectiva, era interessante para os espanhóis estabelecer um vínculo que abrangia desde cativar os indígenas até as articuladas alianças com grupos locais para a colonização do Paraguai e a tentativa de hegemonia na região platina. Muitas vezes, um dos artifícios usados pelos espanhóis era o casamento entre conquistadores e filhas de chefes indígenas. Eram alianças como essas que vislumbravam facilitar e aumentar o poderio dos colonizadores e garantir maior estabilidade para a formação dos povoados.

Segundo Monteiro (1992), com essa estratégia os espanhóis conseguiam mobilizar forças que se confrontavam com outros índios, que resistiam ao domínio espanhol; apropriavam-se das sobras, dos excedentes da agricultura indígena que serviam para o sustento da população espanhola; formavam núcleos de população mestiça através do cruzamento com as mulheres Guarani e exploravam o trabalho indígena, inicialmente procurado 
apenas para a construção dos povoados coloniais mas que, segundo Gadelha (1980), foi se perpetuando para constituir e estruturar o sistema sócioeconômico que se compunha principalmente de uma organização agro-pastoril.

Além da questão da força e do controle de alguns grupos Guarani, os espanhóis usaram de certas estratégias que tinham representatividade cultural para os índios. Por exemplo, adequavam-se à imagem que para os Guarani era de autoridade, exibiam traços de heróis e líderes quando adotavam diversas mulheres num ato de poligamia (tradicional entre os Guarani e que, para a época, era proibitivo para os europeus). Passavam-se por valentes guerreiros numa simbologia que parecia convencer os índios sobre suas qualidades admiráveis. No entanto, na medida em que o ideal colonizador ia se revelando, maximizava-se a exploração sobre os índios e, com o tempo, as alianças se desfaziam e os espanhóis não respeitavam a política de liberdade indígena que era oficial para a região naquela época. Uma maneira encontrada para estabelecer a condição dos índios como cativos dos espanhóis foi estabelecer uma série de serviços obrigatórios para os Guarani (escravidão disfarçada), passando a ser essa uma relação comum entre os colonizadores espanhóis e os índios (Zavalla, 1977).

A opressão espanhola era bastante forte e, em função desta, muitos grupos Guarani deslocaram-se da região do Paraguai em direção à colônia portuguesa do final do século XVI até o início do século XVII. Existem considerações sobre essa mobilidade acreditando-se que seria uma tentativa dos Guarani de se reorganizar tanto política como culturalmente.

Por outro lado, segundo Susnik ${ }^{27}$ citado por Monteiro (1992), os índios considerados rebeldes eram submetidos a uma série de castigos e humilhações e, as vezes, à servidão perpétua. Essa prática fazia com que alguns chefes optassem pela colaboração, pois mesmo que a liberdade fosse parcial e vigiada, ainda assim, era uma maneira de se garantirem em vida, o que não quer dizer que os índios eram pacíficos e submissos, pois ocorreram,

27 SUSNIK, B. Los aborígenes Del Paraguay II, etnohistoria de los guaraníes. Assunción: Museu Etnográfico Andrés Barbero, 1979. 175p. 
pelo menos, 25 sublevações consideradas importantes durante a segunda metade do século XVI.

Um dado interessante sobre as rebeliões quinhentistas dos Guarani é que, em sua maioria elas apresentavam o apelo profético, ou mais exatamente na análise de Melià (1988), "uma típica estrutura profética". Muitos levantes foram realizados por líderes carismáticos por meio de cantos, danças e discursos subversivos que incitavam os índios a abandonarem aquele modo de vida, sempre usando uma linguagem baseada em sua religiosidade.

A dominação espanhola se via limitada por várias fronteiras que iam, desde a resistência apresentada diretamente pelos Guarani, à falta de riquezas minerais, até a distância do mar. No início do século XVII havia alguns poucos núcleos de povoamento e eram, geralmente, pequenos e pobres, apontando para uma provável ineficácia, onde a fome e doenças rondavam sua existência. Coube então aos missionários franciscanos e aos jesuítas a continuação da conquista sobre os Guarani.

\subsection{As grandes missões}

Aproveitando-se da religiosidade dos índios, os jesuítas passaram à formação das grandes missões - reduções - que em uma vasta literatura são apresentadas, por um lado como modelo socialista teocrático ou sociedades cristãs socialistas, e de outro lado como modelo de experiência de despotismo e de cerceamento de liberdade humana. Segundo Monteiro (1992),

\footnotetext{
“(..) a maioria das abordagens sofre de um eurocentrismo extremo, uma vez que as missões raramente representavam mais do que um mero espelho da Europa que no século XVIII, se debatia com o conceito da utopia social (...)".
}

De fato, a questão das missões impregnou a literatura com uma análise sobre os índios Guarani apontando mais uma vez para a servidão, 
embora desta feita idealizando esse índio como se o ele fosse mítico e cristianizado e, na interpretação jesuítica da época, o índio era oprimido por espanhóis e portugueses.

Santos (1987), sustenta a hipótese de que os padres teriam conseguido imprimir a ordem missioneira por intermédio de violência e da aculturação dos indígenas, enquanto Haubert (1989), resume os cinco fatores que puderam levar ao "reducionismo" da análise contida na literatura com referência aos índios e jesuítas nas missões do século XVI e VII, que concorrem para uma grave deformação do entendimento dos estudos missioneiros. Esses fatores podem ser resumidos nos seguintes itens: a pobreza ou fragilidade das fontes documentais; a presença do índio apenas como figurante; a representação da conversão como um feito relativamente fácil e natural; a representação das reduções como estabelecimentos autônomos, livres da interferência do poder colonial e a representação claramente anacrônica do projeto jesuítico.

A Coroa espanhola acreditava que as missões serviriam apenas para atrair e pacificar grupos Guarani que ainda não eram submissos, tinha consciência que muitos desses grupos já haviam hostilizado os abusos dos colonos espanhóis. Segundo Gadelha (1980), uma vez reduzidos, os índios seriam integrados à força de trabalho da colônia, sem muitas dificuldades. $O$ modelo de exploração de mão de obra para o desenvolvimento da colônia caminhou nos mesmos passos que foram seguidos no Brasil pelos portugueses.

Até a expulsão da Companhia de Jesus do Paraguai, em 1767, direta ou indiretamente os jesuítas serviam à colônia e diretamente aos interesses da coroa. Portanto, as missões ou qualquer outra organização jesuítica não foram nunca um "estado" independente, ou como querem alguns autores, um império teocrático independente, política e economicamente. Sabe-se que as missões não tinham que servir aos interesses coloniais apenas no Paraguai, mas também ao vice-reinado no Peru (a autonomia dos jesuítas 
começa a ser mais notada apenas após a fundação da província eclesiástica do Paraguai, desmembrada do Peru em 1607), sem esquecer que os índios reduzidos, invariavelmente, serviram muitas vezes para guardar as fronteiras prestando serviços militares fora das missões (Gadelha, 1980; Kern, 1982; Meireles, 1989).

\subsection{Como o índio pode sobreviver mantendo sua base cultural (?)}

Pode-se considerar que uma das estratégias de sobrevivência dos Guarani perante a fatalidade de serem caçados por portugueses de São Paulo, ou por espanhóis do Paraguai, era a de se juntarem às missões. A incorporação de um grupo indígena numa redução talvez fosse uma estratégia segura para a sua sobrevivência, apontando para uma possibilidade de liberdade, que sempre foi o objetivo máximo dos índios.

Embora reorganizados espacialmente pelos jesuítas, os Guarani mesmo separados em pequenas casas individuais que substituíam a morada coletiva, ainda conservavam um importante laço de parentesco mantendo uma forte relação entre as casas que dividiam sua espacialidade grupal e a chefia tradicional. Segundo Melià (1988), esse comportamento ocorria em meio às quadras da redução.

Pode-se interpretar que, por um determinado momento, esse comportamento poderia parecer como um "acordo entre índios e jesuítas" uma vez que esse dia-a-dia das reduções não foi observado como um ato que pudesse colocar em risco a liberdade dos índios ou o poder dos jesuítas. Todavia, nem sempre seria dessa maneira. Vários eram os problemas enfrentados pelos jesuítas para conter as revoltas que aconteciam no bojo de sua organização. Padres eram mortos por lideranças indígenas e, muitas vezes, as revoltas beiravam à destruição da redução onde a disputa desorganizava o poder central.

Para que os padres continuassem a manter o controle sobre os índios reduzidos, assumiam várias atitudes que eram reconhecidamente 
costumes indígenas, como o fato de discursarem batendo no peito e andando de um lado para o outro. Outra atitude interessante é que muitas vezes deixavam de citar o sexto mandamento ou moderavam sua fala para não provocar as lideranças indígenas que sempre praticaram a poligamia, pois esse era um costume que conferia status para as lideranças indígenas (cf. Meliá 1988).

\subsection{O peso das invasões paulistas sobre o desenvolvimento das missões}

As reduções sofriam uma série de percalços que dificultavam o seu desenvolvimento. Um deles era, sem dúvida, as constantes invasões promovidas pelos paulistas. Existe uma discussão sobre a interpretação que se dá aos motivos que justificariam, naquela época, o investimento das invasões pelos paulistas. Alguns historiadores defendem a proposição de que eram nas reduções que existiam os índios mais treinados para o trabalho, disciplinados e, portanto, melhor condicionados para servir de mão-de-obra nos engenhos do Brasil. Para Davidoff (1982), essa afirmativa subestima tanto o conhecimento de horticultura dos Guarani pré-colonização, como superestima a eficácia de aculturação promovida pelos jesuítas.

Uma análise interessante é realizada por Cortersão ${ }^{28}$ citado por Monteiro (1992), comentando que à época da principal invasão do Guairá (região missioneira, onde hoje é o estado do Rio Grande do Sul) pelos paulistas, as comunidades missioneiras eram recém-formadas, precárias, isoladas e se debatiam em busca de uma economia para servir de base e alicerçar sua sobrevivência. O autor enfatiza que o jesuíta Ruiz de Montoya, superior das missões do Guairá, em uma carta retratava que além dos paulistas e espanhóis, outros problemas eram considerados importantes “(...) as doenças, a fome, as rivalidades faccionais e a guerra intertribal (...)" rondavam as oito reduções daquela província. Monteiro (op. cit.) chama a atenção para o fato de que os portugueses já se interessavam pelos Guarani, de longa data. Os primeiros povoadores da capitania de São Vicente já 
mantinham um intercâmbio de troca e alianças com vários grupos Guarani, isso muito antes das missões, já em meados do século XVI.

\subsection{O relacionamento entre paulistas e Guarani}

A relação entre os paulistas e os Guarani é muito discutida na literatura. Durante certo período, de fato, alguns grupos indígenas seguiam para São Paulo com os paulistas, atraídos por artigos e mercadorias européias que serviriam como um estímulo para esse deslocamento, o que também dificultava o avanço jesuítico, provocando protestos dos jesuítas que alegavam que os Guarani entregariam os próprios filhos por um punhado de mercadorias. Haubert (1990), apresenta uma hipótese sobre essa ação:

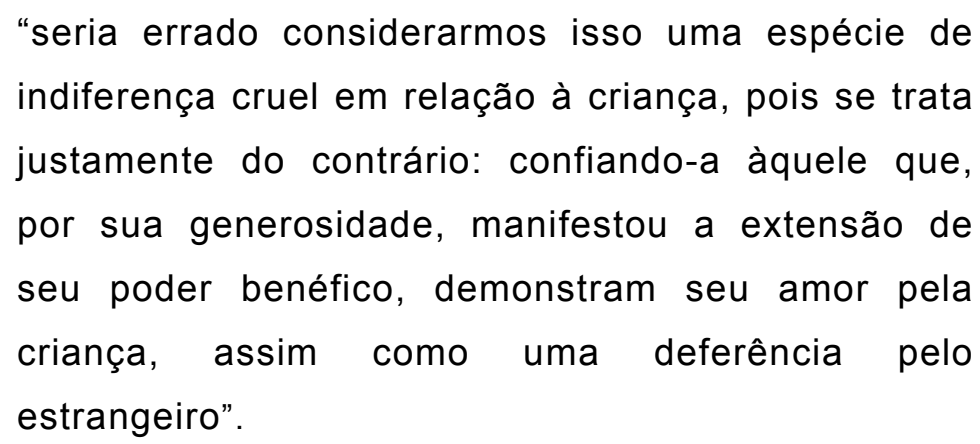

As ações de ataque às missões parecem ter sua lógica fundamentada em um fato muito simples, o custo-benefício. Isto é, os portugueses de São Paulo se valiam dessa ação para manter um estoque de escravos constante, além de negociar os índios como mercadoria, muito valiosa para a época.

Existem registros, segundo Melià (1988), de que antes das invasões a população das missões girava em torno de 35 mil índios em Guairá e cerca de 52.300 na missão do Tape. Sem dúvida, a densidade demográfica das missões era bem maior do que nas aldeias livres na época. Os paulistas, em um curto espaço de tempo, trouxeram para São Paulo entre 30 e 50 mil índios Guarani e aqueles que conseguiram escapar dessa captura se deslocaram para o sul. 
Segundo Haubert (1990), a migração para o sul, se compunha de aproximadamente 12 mil índios. Porém, menos da metade conseguiu atingir as margens do rio Uruguai, sendo que várias adversidades somaram-se para que isso ocorresse: a fome e a doenças além de desentendimento entre os grupos podem ser apontados entre os fatores mais comuns vividos durante a dura trajetória.

Um fato pode ser considerado "positivo" para os jesuítas, reconhecendo e fortalecendo a sua autoridade. Inicialmente os paulistas só aprisionavam a população indígena considerada pagã, ou seja, aqueles que não tinham sido batizados pelos padres jesuítas, ocasião em que recebiam um nome cristão. Essa ação jesuítica passava uma imagem de maior segurança para os índios que estivessem nas missões, pois uma vez reduzidos, gozariam de certa imunidade. No entanto, quando os paulistas passaram a atacar as missões, aumentaram as fugas dos índios, fazendo com que os jesuítas mudassem seus planos. A partir de uma estratégia política, os jesuítas lançaram uma ofensiva diplomática que tentava diminuir o impacto causado pelas ações dos portugueses de São Paulo. Uma delas foi a de que os inacianos conseguiram uma legislação proibindo a escravidão indígena no Brasil e um rescrito papalino que continha uma decisão de caráter particular denunciando em linguagem enérgica as atividades dos preadores, tanto paulistas como paraguaios.

De qualquer forma, os paulistas muito contribuíram para o fortalecimento das missões, pois o fato de suas diversas investidas para aprisionar os indígenas sob o domínio dos jesuítas incentivou a ação de tornarem as missões reducionistas melhor protegidas, a partir da metade do século XVII, colocando-as no caminho da prosperidade. Segundo Monteiro (1992), as reduções alcançaram uma extraordinária estabilidade e mesmo registrando-se surtos epidêmicos de doenças, apresentaram, nesse período, certo crescimento populacional. 


\subsection{Os Guarani e sua importância na construção de São Paulo}

A importância dos bandeirantes para a formação e crescimento de São Paulo é, sem sombra de dúvida, discutida e rediscutida em vasta literatura, sendo que parte da historiografia os apresenta como os grandes desbravadores dos sertões interioranos, como homens decididos a estenderem as fronteiras brasileiras para além dos tratados, e capazes de resistir a todos os tipos de hostilidades que o planalto poderia oferecer. Esses grandes heróis que os brasileiros (atuais) acostumaram-se a ver estampados nos livros escolares, foram os mesmos que capturaram e escravizaram os índios Guarani por mais de um século.

A grande pergunta que se faz é sobre o destino dos milhares de índios tirados das missões além dos outros que não estavam reduzidos e que eram capturados nas matas, nos caminhos entre as missões e nos sertões de toda a região sudeste do Brasil. Qual teria sido o destino desses índios?

A equivocada leitura que se faz sobre o desenvolvimento de São Paulo passa diretamente pela questão econômica e, em sua racionalidade, apresenta uma justificativa que envolve tanto a ação dos bandeirantes com relação aos índios como o movimento internacional na época, caracterizando a ação dos bandeirantes como a única saída encontrada para o desenvolvimento das terras planaltinas. A explicação recorrente é apresentada por Ellis Junior (1938). O autor chama a atenção para o fato dos paulistas terem atacado as reduções na mesma época em que ocorriam as invasões holandesas no nordeste do Brasil e também em Angola. A idéia é mostrar que a diminuição do fluxo de cativos africanos colocaria os índios num valor de mercado condizente com a empreitada. A região de São Paulo estava longe do mar, ou mais exatamente, separada por uma barreira natural, a Serra do Mar que divide o planalto da capitania de São Vicente. Não se sabia de ouro, prata ou pedras preciosas, portanto, a economia de São Paulo colonial, teria sido a de uma modesta agricultura de subsistência. 
Segundo Monteiro (1992), são análises como as de Ellis Junior que alimentam a apologia favorável aos paulistas, "pois os índios pilhados das missões encontram-se reduzidos (mais uma vez) a meras mercadorias, sequer parando no planalto, a não ser um pequeno resíduo que não fosse comercializado no litoral". Na análise de Ellis Junior (1938) o comércio de escravos índios, realizado pelos paulistas, somou 350 mil cativos tomados ao longo do século e, desse montante, $80 \%$ foram destinados ao mercado litorâneo. Contrapondo essa visão, Monteiro (op.cit.) referencia a documentação colonial para evidenciar que o surto sertanista de 1628 a 1641, está muito mais ligado ao desenvolvimento da economia do planalto do que à negociação de escravos para o litoral açucareiro.

Por volta de 1640 desenvolvia-se na agricultura planaltina um grande plantio de trigo. Muitos dos participantes das bandeiras voltavam-se para atividades mais sedentárias e mesmo que retornassem ao sertão algumas vezes mais, estabeleceram no planalto uma vida mais dedicada ao desenvolvimento de uma agricultura lavrada à mão indígena.

O exemplo de Raposo Tavares que tinha um plantel de 117 índios sob seu comando, em próspera fazenda em Quitaúna, ao longo do rio Tietê, entre as vilas de São Paulo e Parnaíba, ilustra bem essa situação. Outros, como os irmãos André, Domingos e Baltasar Fernandes, com a partilha de escravos índios formaram a base das vilas de Parnaíba, Itu e Sorocaba. No estudo de Monteiro (1988a) sobre a força de trabalho dos índios na sociedade colonial de São Paulo durante o século XVII, o autor afirma que foi exatamente naquele período que se pode constatar o maior crescimento da concentração de índios arrolados nos inventários de bens das vilas de São Paulo e Santana do Parnaíba.

Então, ao se analisar a proposição de que São Paulo tinha uma fraca agricultura de subsistência, a pergunta é simples: para que tanta mão de obra? Holanda (1995) constrói um binômio que apresenta um entendimento real para a questão: "grande propriedade, pequena lavoura", para o autor 
existe uma explicação para a permanência passageira de tantos índios em algumas propriedades; ele considera que eram recém-chegados do sertão e seriam destinados a outros mercados, ou mesmo, a uma posterior redistribuição interna. Em sua explicação justifica esse procedimento:

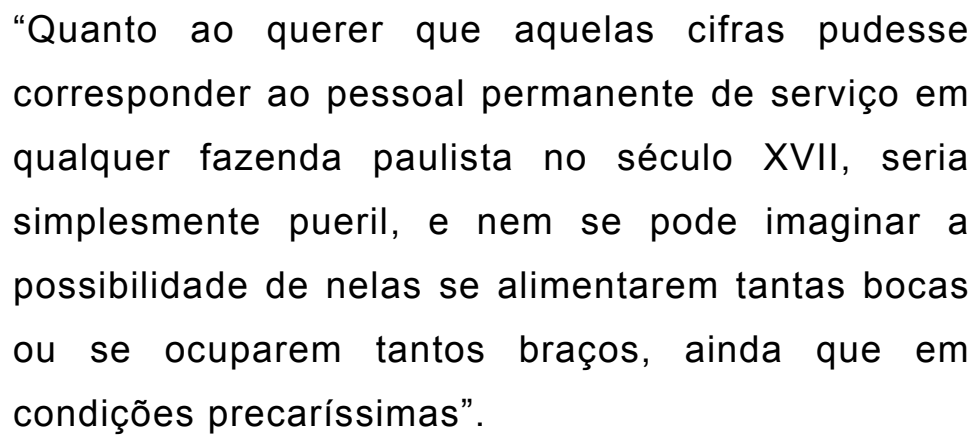

A bem da verdade sabe-se que a historiografia preferiu muitas vezes se compor de dados mais amenos a respeito da usurpação dos paulistas sobre os índios Guarani. Poucos trabalhos dão importância ao assunto "escravidão indígena em São Paulo". Além do mais, uma vez que a captura, escravização e comercialização dos índios eram legalmente proibidas, os bandeirantes, na verdade, além de capturarem e escravizarem, também vendiam os índios, o que os coloca na categoria de traficantes, e os historiadores preferiram "dar um jeitinho" e os absolver desse crime. Para uma visão científica mais profunda sobre essa realidade, existe um trabalho intitulado "Mamelucos" (Zenha, 1970), que discorre sobre o ofício de escravista e a relevância do papel dos índios no estado de São Paulo.

Pode-se reformular a concepção de que São Paulo, naquela época, desenvolvia-se a partir de uma simples economia de subsistência. A partir da análise feita por Monteiro (1988b) que, em levantamentos realizados em documentação da própria colônia, revela que no período colonial muitos relatos atestam que a mão de obra nativa se fazia presente não apenas na agricultura, mas era igualmente muito comum no transporte e no sertanismo. Segundo o autor, o motor da economia do século XVII era o setor de abastecimento, sendo que o constante transporte de mercadorias no lombo dos índios pela 
Serra do Mar tinha tanta importância para São Paulo que se tornou por muito tempo o que articulava as formas de apropriação e uso do solo, fazendo com que os paulistas tivessem de fato, uma grande atividade como sertanistas de apresamento.

Portanto, os Guarani tiveram imprescindível papel na construção de São Paulo e, de acordo com Monteiro (1989), sua inserção na sociedade colonial foi importante sobre vários aspectos, desde a influência no crescimento populacional, até a estabilização de uma estrutura de transporte para o abastecimento e excedentes entre São Paulo e as vilas circunvizinhas, além de São Vicente. Segundo o autor, em pouco tempo a atividade escravista tornou-se um circulo vicioso, reproduzindo a história do litoral no que diz respeito à sua demografia no século $\mathrm{XVI}$, que também tinha um paralelo no Maranhão seiscentista.

Freqüentes surtos epidêmicos dizimavam os índios vulneráveis àquelas doenças. Isso estimulava a captura de mais índios que, por sua vez, também eram suscetíveis às doenças, formando um circulo vicioso que se estendeu por muito tempo. Pode-se acrescentar a isso uma má alimentação, pois como foi citado anteriormente por Holanda (1990), não havia tanta comida para tantas bocas. Ao se comprovar que o transporte de mercadorias entre o porto de São Vicente e as cidades do planalto era feito pelos Guarani, pode-se ter uma formulação hipotética que atende tanto a uma suposição positiva sobre o número de índios que ficavam sob a responsabilidade dos paulistas, como à sua redistribuição interna, referindo-se à questão de mão-de-obra para a formação de outras vilas e para a agricultura.

Embora existisse legislação contrária à escravização indígena, também existiam formas de se burlar as leis. Os índios Guarani deixavam de ser referidos como cativos ou escravos e, passaram a ser denominados como "administrados" pelos paulistas que os comercializavam como mera mercadoria ou os dispunham, segundo Casal (1976), para pagamento de dívidas e como dotes de casamentos. 
De fato, a escravidão perseguiu os Guarani de várias formas sendo que os jesuítas consideravam que a redução os mantinha livres e Ihes tirava o peso de serem pagãos, pois ali seriam batizados e receberiam um nome cristão. Os jesuítas apresentavam muitos outros argumentos que defendiam a "liberdade" dos índios sob sua responsabilidade. Em contra-partida os paulistas alegavam que os jesuítas mantinham os indígenas sob rigoroso sistema de cativeiro, ao passo que com os paulistas, aprendiam a se sustentar.

Segundo Ennes ${ }^{29}$ citado por Monteiro (1992), o conhecido Domingos Jorge Velho em uma missiva, escrita em plena campanha contra os Palmares, retrata fielmente esse sentimento:

"Se ao depois (de reduzir os índios) nos servimos deles para nossas lavouras, nenhuma injustiça lhes faremos; pois tanto é para os sustentarmos a eles e a seus filhos como a nós e aos nossos; e isto bem longe de os cativar, antes se lhes faz um remunerável serviço em os ensinar a saberem lavrar, plantar, colher e trabalhar para seu sustento, coisa que antes que os brancos tho ensinem, eles não sabem fazer"

\subsection{As formas organizacionais dos Guarani resistiam à poderosa estrutura de opressão}

A respeito da organização política dos Guarani durante toda essa opressão, é importante salientar que a historiografia apresenta, mesmo que em documentos dispersos, uma série de dados que remontam à idéia de que esses índios conseguiam, ainda que de forma provavelmente frágil e categoricamente

29 ENNES, E. A guerra dos Palmares. São Paulo: Ed. Nacional, 1938. 501p. 
menor, manter em seus grupos certa conformação política. Verifica-se, segundo os dados dos Inventários ${ }^{30}$ citado por Monteiro (1992) que:

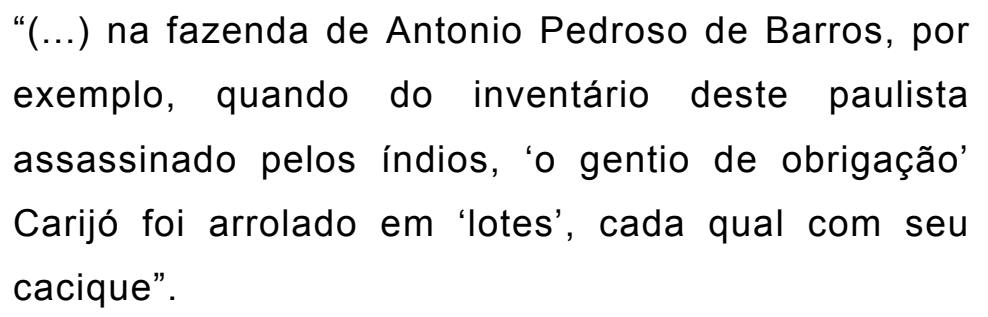

Contudo, notava-se a ausência da figura do xamã e do profeta no planalto durante o século XVII. Monteiro (op. cit.) atribui ao fato desses elementos terem sido eliminados pelos paulistas, um dos motivos que levaram os paulistas a terem êxito onde os jesuítas fracassaram. Evidentemente, o autor não está simplificando essa questão nem mesmo condicionando o relativo sucesso dos paulistas com relação aos índios. No entanto, ele apresenta uma hipótese que parece ser plausível no tocante à dominação sobre os índios versus sua sobrevivência e continuidade cultural: o fato da figura do pajé (xamã) estar ausente, ou talvez não ser notado nas fazendas e nas vilas na época, não significa que eles deixaram de existir.

A documentação da época, muito fragmentada e dispersa como a própria historiografia retrata, associada ao pouco que se sabe da vida cotidiana dos índios, e mesmo dos portugueses da época, deixa escondidas no tempo várias formas de resistência da etnia Guarani, adaptações e acomodações das duas partes, culminando como a existência que acabaria sendo "vantajosa" para ambas. O debate sobre a ocorrência de uma "coibição até certo ponto absorvida", que nada mais é que a persuasão exercida sobre os indígenas pelos paulistas dos séculos XVI e XVII, pode ser analisada como uma demonstração de que havia, de lado-a-lado, uma troca de informações e conhecimentos que tanto moldava portugueses de São Paulo como os Guarani a uma nova realidade, e ambos os lados acomodaram costumes desde a língua falada até o aprendizado de muitas tradições.

30 INVENTÁRIOS. Inventários e testamentos. São Paulo: Imprensa Oficial do Estado, v.20. (1921) 1977. 
Os estudos realizados por Holanda (1995), oferecem dados sobre a influência e transferência do conhecimento indígena para os paulistas, inclusive referenciando que isso havia contribuído para a formação da cultura na época da colonização. De fato, boa parte evidencia-se até o presente, como o vocabulário, a pesca, a agricultura itinerante, o conhecimento da flora e da fauna, entre tantos outros capítulos de seus costumes que passaram a ser comum a toda gente de São Paulo. Muitos dos costumes atribuídos às populações tradicionais, como os caiçaras, sabe-se que foram aprendidos por estes pelo convívio de seus antepassados com os índios. Por exemplo, quando são analisados os instrumentos da pesca artesanal, em sua maioria os nomes são do vocabulário tupi-guarani ou, quando muito, aportuguesados a partir dessa origem.

Alguns fatos merecem ser comentados devido à sua ligação com nomes muito conhecidos dos livros acadêmicos, como os de Brás Leme e Pedro Vaz de Barros, dois grandes proprietários de terras que adotaram a poligamia, um costume reservado aos chefes indígenas e que lhes dava status. Os dois paulistas citados praticavam abertamente a poligamia, sendo que o último era destacado pelas autoridades régias. Segundo Leme (1980), isso ocorria devido ao "grande cabedal que tinha em índios".

Outro dado interessante verifica-se a respeito do etnônimo "Carijó", inicialmente usado para designar o índio Guarani e, posteriormente, usado pelos paulistas para nomear a população sujeita à administração particular, incluindo qualquer índio de qualquer etnia, e muitas vezes também os mamelucos.

O etnônimo carijó também foi assumido como identidade étnica pelos índios da região de São Paulo. Monteiro (1990) oferece a argumentação de que os indígenas quando moviam disputas jurídicas em prol de sua liberdade, muitas vezes declaravam serem descendentes de Carijó. Com essa atribuição e com a prova da injustiça de seu cativeiro, o autor do processo 
podia ganhar sua alforria. Porém, muitos preferiam procurar uma existência mais digna no próprio interior do instituto escravista.

Os procedimentos jurídicos abertos por indígenas no século XVII não eram muito comuns ou, pelo menos, não atingiam uma grande parte dos índios. Também está pouco presente na historiografia, se bem que nos anos finais da chamada "administração particular", esse subterfúgio foi um instrumento mais procurado pelos índios. No entanto, se libertos, os remanescentes dos Guarani não conseguiam necessariamente a recuperação de sua identidade e passavam a fazer parte da maioria da população pobre formada de mamelucos e brancos, que compunha a população rural (Monteiro, 1992).

Talvez por reconhecer que, fora do sistema de escravidão (administração particular), suas dificuldades seriam maiores e seu afastamento dos parentes seria um fato consumado, muitas vezes os índios fugiam de uma propriedade indo se alojar em outra da mesma região, trocando apenas de "senhor".

A versão convencional da bibliografia paulista atribui ao escravo índio uma ingenuidade que, juntamente com as diversas passagens que compõe essa idéia, formam uma visão do índio vinculado à mata e não à sua cultura. Na seguinte passagem da obra "Vida e Morte do Bandeirante" de Alcântara Machado, Monteiro (1992), argumenta sobre o tratamento dado à questão das fugas dos índios, que se tornou "verdade", independente da realidade. Nessa obra é veiculada a imagem do índio que sente saudade das matas da qual era conhecedor, e das terras, saudoso de sua aldeia natal. Portanto, era propenso às fugas constantes, pois o sertão era "o grande, o eterno, o verdadeiro amigo e redentor dos indígenas" (Machado, 1980).

No entanto, ao se estudar a questão da "administração particular", pode-se constatar que os índios fugiam por vícios do próprio sistema. Isto é, às vezes eram coagidos por outros donos de terra para fugirem para suas propriedades e, muitas vezes, evadiam-se por conta própria em busca de maior 
liberdade, mas com freqüência, iam para propriedades próximas, na mesma região. O que na verdade o índio queria era a liberdade de movimento e, principalmente, o direito de visitar parentes e reencontrar familiares separados nas partilhas. Aliás, a movimentação dos Guarani de uma aldeia para outra foi um costume que sempre esteve presente no seio dessa etnia e permanece até os dias de hoje.

\title{
3.12 Os Guarani hoje: comentários enfocando principalmente a aldeia Morro da Saudade
}

\begin{abstract}
"Ao se auto-identificarem como índios, percebem que os 'outros' são: o chefe do posto, o enfermeiro, a professora, o turista que compra o artesanato e o dono do armazém. São também 'outros': o chefe da ajudância, a FUNAI, o governo, os arrendatários para os quais trabalham, os intermediários por meio dos quais comercializam os produtos de sua roça, os bóiasfria, trabalhadores iguais, mas não-índios e os invasores de terra. Através da compreensão de quem são os outros, os índios explicitam elementos fundamentais para sua auto-identificação". (Borelli \& Luz, 1984, p.18)
\end{abstract}




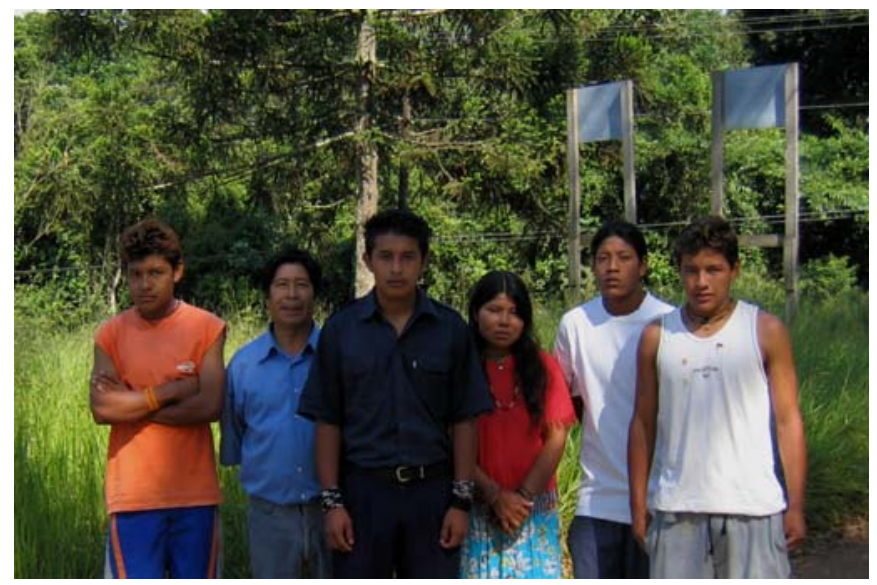

Figura 2 - Karai Poty (de camisa azul clara), esposa e sobrinhos, em 2005. Onde antes (1989) se via sua moradia, existe hoje um pinheiro adulto

Atualmente, em território brasileiro, existem três grupos diferentes de índios Guarani: M'byá, Kaiová e Nhandéva (ou Xiripá). Segundo Schaden (1954), esses grupos são distintos conforme a diferença de dialeto, costumes e práticas rituais. Ladeira \& Costa (1995), acrescentam à usual divisão formulada anteriormente, a questão territorial, observando a disposição dos espaços ocupados pelos grupos dentro de um mesmo e amplo território tradicional, lembrando que embora os Guarani Kaiová concentrem-se no Mato Grosso do Sul, existe uma superposição dos M'byá e dos Nhandéva em algumas regiões no sul e sudoeste brasileiro, devido a migrações realizadas por famílias pertencentes a esses grupos.

Mesmo sabendo-se de uma miscigenação existente entre os grupos Guarani, no caso dos M'byá é mantida uma unidade religiosa e lingüística bem determinante, que os diferencia dos outros grupos. Segundo Ladeira (1992), isso os permite reconhecer seus iguais, mesmo que habitando aldeias em regiões distantes, envolvidas por distintas sociedades nacionais: Brasil, Argentina, Paraguai e Uruguai.

Ainda hoje o processo de migração é notado entre os M'byá a partir do Paraguai, Argentina e do interior do estado do Rio Grande do Sul, 
evidentemente em grupos muito menores comparando-se com aqueles dos séculos XVI a XVIII. Monteiro et al. (1984); Ladeira \& Azanha (1988) e Ladeira (1992), discorrem sobre migrações recentes (século XX) dos Guarani e, transcrevem depoimentos de vários índios ainda vivos e moradores nas aldeias do litoral paulista.

Mesmo sabendo-se de uma miscigenação existente entre os grupos Guarani, no caso dos M'byá é mantida uma unidade religiosa e lingüística bem determinante, que os diferencia dos outros grupos. Segundo Ladeira (1992), isso os permite reconhecer seus iguais, mesmo que habitando aldeias em regiões distantes, envolvidas por distintas sociedades nacionais: Brasil, Argentina, Paraguai e Uruguai.

Ainda hoje o processo de migração é notado entre os M'byá a partir do Paraguai, Argentina e do interior do estado do Rio Grande do Sul, evidentemente em grupos muito menores comparando-se com aqueles dos séculos XVI a XVIII. Monteiro et all. (1984); Ladeira \& Azanha (1988) e Ladeira (1992), discorrem sobre migrações recentes (século XX) dos Guarani e, transcrevem depoimentos de vários índios ainda vivos e moradores nas aldeias do litoral paulista.
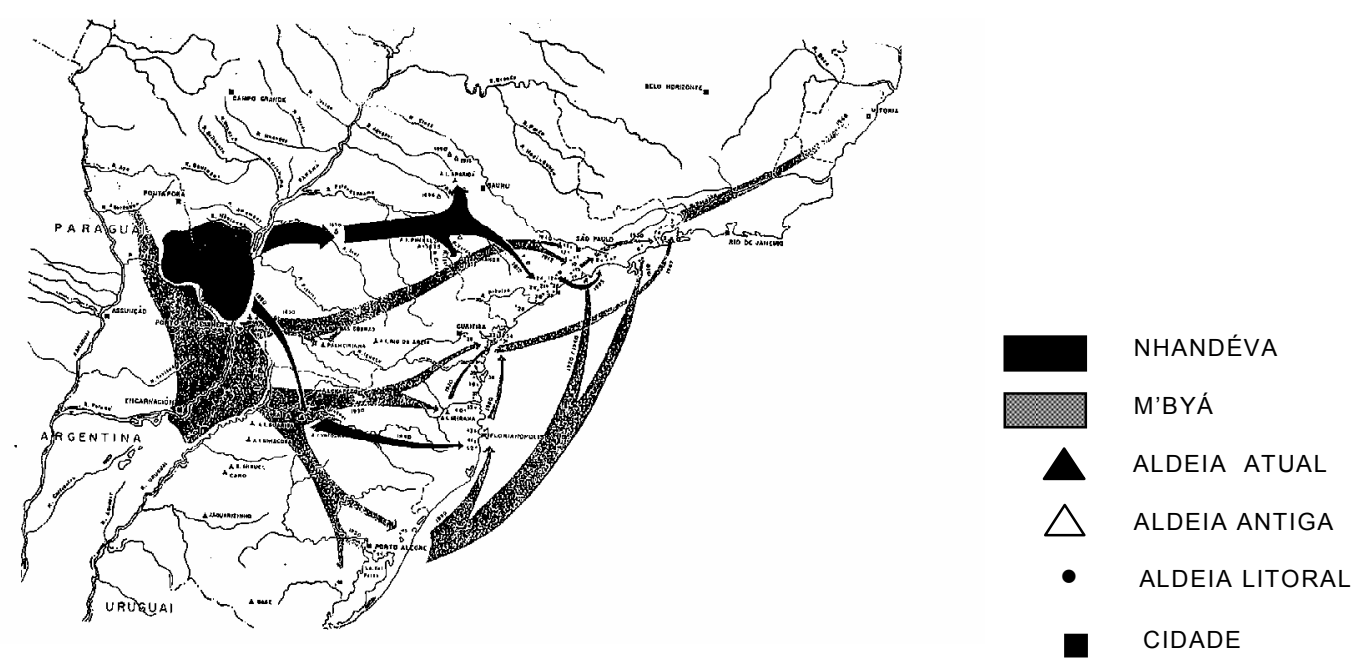

Figura 3 - Mapa histórico das Migrações Guarani

Fonte: adaptado de Ladeira (1992) 
Essa movimentação, no caso dos M'byá, tem se dado em direção ao litoral, sempre ocupando áreas de Mata Atlântica e suas aldeias podem ser localizadas em território brasileiro desde o estado do Rio Grande do Sul até o estado do Espírito Santo. A mobilidade dos Guarani M'byá dentro de seu extenso território, como foi visto anteriormente, é fator que fundamenta sua organização sócio-política e, embora seja possível constatar que muitas movimentações se dão por motivos internos (discordância política e rompimento com a liderança local), muitas vezes, segundo Ladeira (1992), esse movimento é confundido com o movimento migratório em busca da "terra sem mal".

Os M'byá também são encontrados, em outras regiões do Brasil, como a região norte, em populações muito menores, onde algumas famílias que se originaram a partir de um mesmo grande grupo, chegando ao Brasil depois da Guerra do Paraguai. Atualmente no estado do Pará, no município de Jucundá, em Tocantins numa das áreas Karajá de Xamboiá, podem ser encontradas algumas poucas famílias dispersas na região.

Segundo Schaden (1954), M'byá siginifica "gente". Trata-se de a autodenominação mais usada pelos Guarani que, também são usualmente vistos na literatura como Kainguá, Kaivá. Schaden (1948), denomina os M’byá como Tambéopé (xiripá largo) ou Txeirũ, Ñaneiru (no sentido de "meus ou nossos amigos"), que é como os Nhandéva se referem aos M'bya. A denominação Apüteré, ou seja, Apyteré (corruptelas: Apuiteré, Apiteré), também pode ser encontrada para se referir a esse subgrupo dos Guarani. Entre os paraguaios, na época dos estudos desenvolvidos por Shaden (1948 e 1954), os M'byá, eram conhecidos por um apelido "Baticolas", devido ao chiripá (certa indumentária), usado entre as pernas. Existe uma certa confusão quando se fala dos M'byá e os Nhandéva. Os M'byá também se auto-denominam Nhandéva. O significado de nhandéva literalmente é "nós", "nossa gente" ou "os que somos nós". A interpretação confusa ocorre devido ao fato de um índio M'byá, referirse a si mesmo como nhandéva, e não ao grupo a que pertence. 
Como a vinculação entre os M'byá se apóia fundamentalmente nas relações familiares e se sustenta numa analogia marcada pela solidariedade entre os componentes da família extensa ${ }^{31}$, essa atividade tem função de agregar os componentes da família num determinado momento, em uma aldeia. A complexidade que envolve essa relação (principalmente nos dias de hoje, quando o território desses índios está retalhado e interrompido e vive sob pressão da sociedade não-índia), apresenta-se viva nas histórias que os índios contam da extensão de suas famílias e na própria formação das novas aldeias, como pode ser verificado no depoimento do índio Nivaldo ${ }^{32}$ sobre a formação da Aldeia Morro da Saudade (Ladeira,1984).

Uma discussão sempre presente nos debates acadêmicos a respeito da interação sociocultural entre os Guarani M'byá, se baseia na hipótese de ocupação territorial de configuração não contígua, por um extenso território, para esse grupo dos Guarani. Schaden (1954), Ladeira (1992; 1995; 2001), Melià (1990), Monteiro (1992) (apenas para citar alguns autores), afirmam que tal interação, além de garantir uma forma organizacional própria, também é fator importante para que o grupo mantenha controle sobre a transmissão de características culturais milenares presentes até os dias atuais.

Ao citar algumas aldeias mais conhecidas e mais antigas, originadas no final do século XIX e início do século XX, podemos citar a aldeia Itariri, que existe há mais de 100 anos, e Rio Branco, um pouco mais nova, mas também com mais de 100 anos, como sendo as aldeias que recebiam extensas famílias vindas do sul do Brasil. Segundo Ladeira (1984), eram famílias que partiam em direção ao litoral de São Paulo descontentes, na época, ao modo de vida a que estavam submetidas pela Fundação Nacional do Índio (FUNAI).

A formação da Aldeia do Rio Branco, ponto de passagem de muitas famílias para depois formarem outras aldeias, ocorreu a partir de um grupo

31 A família extensa é composta, segundo a tradição Guarani, em princípio, pelo casal, as filhas, os genros e os netos. Esse agrupamento forma uma unidade de produção e consumo. 32 Para a leitura do depoimento completo do índio Nivaldo, ver anexos. 
M'byá que, provavelmente, se deslocara do leste do Paraguai e noroeste da Argentina.

Um detalhe interessante pode ser destacado sobre os estudos dos Guarani, no caso dos M'byá atuais. Acredita-se que são descendentes de grupos que não se submeteram nem aos missionários jesuítas em suas missões ou aos "encomendos" espanhóis (Cadogan, 1959a). Essa afirmação decorre de pesquisas realizadas pelo autor ${ }^{33}$, porém, é pouco citada na literatura.

Como já foi registrado anteriormente, muitas vezes os grupos Guarani são mencionados de uma maneira na qual, para quem não tem uma leitura básica inicial, os Guarani parecem ser todos uma única e grande família distribuída pelo sul do continente latino americano, criando uma certa confusão na interpretação dos dados como, por exemplo, do mapa produzido por Nimuendaju (1981), e mesmo, o mapa histórico das migrações dos Guarani para o Litoral, de Ladeira \& Azanha (1988).

As informações a respeito dos M'byá em território brasileiro são escassas e confusas, ou por falta de documentos, imprecisão de dados, ou mesmo, pela própria mistura de grupos isolados, como explica Schaden (1963):

"não ocorrem apenas da natureza fragmentária e
insegura dos nossos conhecimentos, como também
do fato de que os vários grupos Guarani outrora
isolados, passaram nestes últimos séculos, por
intenso processo de aculturação mútua, que
evidentemente, obliterou grande parte das
diferenças originais"

33 Diversas obras de Leon Cadogan, que é considerado um dos maiores conhecedores sobre os Guarani, concluem que os M'byá, alguns grupos, se esconderam nas matas interioranas e escaparam da submissão se refugiando nas florestas tropicais do Guairá paraguaio, Cadogan (1948 apud Ladeira \& Azanha, 1988). 
No entanto, Ladeira \& Azanha (1988), apontam duas possíveis rotas para a presença dos M'byá em território brasileiro: uma delas sai da Argentina entrando no Brasil pelo estado do Rio Grande do Sul. Os autores afirmam que esse deslocamento é o que mais tarde irá formar o aldeamento do Rio Branco e Boa Vista (Ubatuba), ambos no estado de São Paulo, bem como o aldeamento de Boa Esperança, no estado do Espírito Santo. A outra rota é traçada a partir do Paraguai, em direção ao estado do Paraná, formando vários aldeamentos, entre eles o de Rio das Cobras e Palmeirinha. Segundo os autores é, a partir dessa segunda rota "que, mais tarde, será responsável pelo grosso da população M'byá dos aldeamentos de São Paulo e Rio de Janeiro".

Litaiff \& Darella (2000), apresentam uma interessante informação sobre a migração e mobilidade ${ }^{34}$, dos Guarani. Sustentam que, atualmente, são os únicos a manterem um deslocamento em direção às regiões litorâneas em busca de terras que ainda possuam Mata Atlântica e que os autores afirmam ser um "componente intrínseco de sua cultura". Cabe acrescentar que os M'byá se deslocam em seu território, porém nunca abandonam por completo suas antigas aldeias. Segundo os autores (op. cit.), na temática da migração, mobilidade e deslocamento, alguns depoimentos fundamentam o entendimento dessa sociedade e:

"Alguns lideres afirmam que após a Guerra do Paraguai, os Guarani intensificaram movimentações populacionais no interior da América do Sul, em direção à costa brasileira, juntando-se a pequenos grupos que aqui viviam. Segundo relatos de alguns informantes, os principais motivos que levaram e levam centenas de Guarani a se deslocarem foram e ainda são: a busca de uma terra "melhor" para morar, com florestas, evitação e evasão de áreas

34 "Mobilidade é a conceituação dada ao movimento de intercâmbio entre as aldeias, reforçando as relações sociais e de reciprocidade; casamentos; visitas a parentes, troca de informações, sementes, mudas de plantas, conhecimentos adquiridos nas relações com as diversas sociedades envolventes; assembléias, conselhos" (Litaiff \& Darella, 2000). 
ocupadas por outros grupos étnicos, bem como o estabelecimento em locais que dificultem o acesso de estranhos".

Na década de 1940, as famílias que vinham do sul do Brasil e haviam passado por Itariri e por Rio Branco formaram a Aldeia de Rio Silveira, na região denominada Barra do Una, em São Sebastião, no litoral norte de São Paulo. De uma cisão política interna entre seus habitantes, três famílias abandonam a Aldeia do Rio Silveira formando em Ubatuba, no mesmo litoral, a aldeia Boa Vista, na década de 1960. Esse não era um percurso escolhido ao acaso; as áreas selecionadas para fundarem a aldeia eram em terras onde seus antepassados haviam vivido.

A cidade de São Paulo possuía, até cerca de 30 anos, quatro aldeias: Aldeia da Barragem, Krucutu, Mboi-Mirim e Jaraguá. A aldeia de MboiMirim foi formada por uma família que migrou do Rio das Cobras, estado do Paraná, para a Aldeia da Barragem, por motivos políticos. Foi feito um acordo com a Arquidiocese de São Paulo e essa família aceitou o convite de um padre que dirigia o Instituto Rural Cardeal Agnelo Rossi e passou a viver em uma área de 11 alqueires, alojados em casas de madeira compartimentada. Entretanto, a experiência não vingou e acabaram voltando para a Aldeia da Barragem. Na aldeia Krukutu, bem próxima à barragem, cerca de $5 \mathrm{~km}$, inicialmente, uma família extensa havia vivido ali na década de 1970, tendo abandonado o local porque brancos com intenção de se apropriarem daquelas terras atearam fogo em suas casas.

Outra família extensa foi para a Aldeia Krukutu, ainda na mesma década e vivem lá até o presente. Hoje a população chega a 100 habitantes. Essa aldeia mantém um ótimo relacionamento com a Aldeia Morro da Saudade. E a Aldeia Jaraguá, que recebe essa denominação por estar localizada ao pé do Pico do Jaraguá, foi formada por uma família extensa na década de 1960. É uma área de 2 hectares que, atualmente, é a morada de uma das maiores autoridades religiosas de todos os Guarani M'byá, o cacique José Fernandes. 
A Aldeia da Barragem, cujos detalhes de localização serão explicitados mais adiante, atualmente recebe a denominação de Aldeia Morro da Saudade e foi formada a partir de famílias que fugiam da Aldeia de Palmeirinha, que fica no Posto Indígena de Mangueirinha, no estado do Paraná. Essas famílias saíram de Palmeirinha por não suportarem a situação de fome e humilhação a que eram submetidas pelo chefe do posto indígena, funcionário da FUNAI.

Não cabe aqui o relato de vida de alguns índios que ainda estão vivos, mas a situação em que viviam no Paraná não era diferente daquela que viviam sob a "administração" dos portugueses de São Paulo nos séculos XVI e XVII. As informações que se seguem, sobre a formação da Aldeia Morro da Saudade, foram compilados do depoimento do índio Nivaldo, colhido pela antropóloga Maria Inês Ladeira em 1984 e merecem um espaço neste trabalho por elucidar algumas controvérsias a respeito dos Guarani atuais.

As famílias vindas de Palmeirinha foram para Itariri onde ficaram por cerca de três meses e fugiram em direção à Aldeia do Rio Branco. Permaneceram ali por um curto período de tempo e seguiram para a Aldeia do Rio Silveira, onde ficaram por cerca de três meses e tiveram que sair. Não tendo se fixado a nenhuma das aldeias resolveram voltar para Palmeirinha, pois segundo o depoimento do índio Nivaldo, não sabiam para onde ir. Por terem fugido de Palmerinha, o chefe do posto indígena não permitiu que ficassem por lá. Desta vez, as famílias foram para a cidade de São Paulo, encontraram outros Guarani e acabaram voltando para a Aldeia Rio Branco onde não se adaptaram à presença de muitos mosquitos e foram se alojar no bairro Capela do Socorro (zona sul da cidade de São Paulo), ficando acampados sob a Ponte do Socorro (localizada sobre o Canal do Rio Jurubatuba, na extremidade sul da Av. das Nações Unidas, conhecida popularmente como "Avenidas Marginais do Rio Pinheiros") por cerca de três meses. Daí foram levados por um japonês que os convidou para trabalharem numa terra, segundo o depoimento do índio Nivaldo, ali se estabeleceram, área atual da Aldeia Morro da Saudade. Sobre o tempo de permanência declarado 
pelo índio Nivaldo, nos locais citados anteriormente, existem controvérsias sobre o número de meses em cada local.

A Aldeia Morro da Saudade, localizada no perímetro urbano da cidade de São Paulo, em sua periferia, no distrito de Parelheiros, latitude: S2352'02" e longitude: W-46³8'59", apresenta atualmente uma população de aproximadamente 600 índios, é visitada por um grande número de pesquisadores de várias áreas científicas diferentes. É muito comum antropólogos, psicólogos, assistentes sociais, biólogos ..., se encontrarem no mesmo dia de campo, sem nem ao menos se conheçam.

Invariavelmente, a aldeia é visitada por entidades nãogovernamentais-assistencialistas que levam doações como comida, roupas e remédios. Também é comum, mais até que de pesquisadores e de ONG's, a presença de religiosos. Esses religiosos, na maioria das vezes praticam seus cultos no território da aldeia e sempre envolvem os índios, adultos e crianças, que muitas vezes são agraciados com uma porção de alimentos. Essa última categoria de visitantes é formada por pessoas do segmento dos cristãos (evangélicos e católicos) que muitas vezes induzem os índios a seguirem a religião cristã. Vários índios já foram vistos na aldeia com a bíblia cristã, seguindo para o "templo" que fica nas imediações.

Atualmente, a Aldeia Morro da Saudade possui escola de ensino fundamental da Prefeitura Municipal de São Paulo, com aulas em língua portuguesa e também uma escola onde os ensinamentos são transmitidos por professores indígenas, em língua guarani, no dialeto m'byá. As duas construções são em alvenaria, com eletricidade, água encanada, banheiros, cozinha com fogão a gás e a estrutura também abriga carteiras escolares, quadro negro, computadores, telefones, antena parabólica, arquivos, mesas diferenciadas para os professores e outros mobiliários. A poucos metros dessas construções existe um centro comunitário com as mesmas características onde se localiza a sede de uma associação indígena, considerada uma força política e cultural que organiza diversas ações culturais 
e, invariavelmente, realiza movimentadas reuniões entre caciques de diversas aldeias.

Um número considerável de seus habitantes trabalha fora da aldeia em uma variável lista de atividades, sendo que em nenhum caso o emprego representa um ganho condizente ou, ao menos, necessário para a sobrevivência da família.

A área da aldeia é muito pequena, cerca de 23 hectares onde podem ser encontradas pequenas roças isoladas no pouco de terra que serve para a agricultura de subsistência. Normalmente verifica-se o plantio de milho, de mandioca, de batata doce e, às vezes de feijão. Existe um campo de futebol muito freqüentado aos finais de semana, sendo que a aldeia possui um time uniformizado formado por seus jovens que, inclusive, acumulam alguns troféus. Sempre alguns times dos bairros vizinhos disputam partidas aos sábados e domingos, pela manhã.

Todos os índios dessa aldeia falam o idioma guarani, dialeto m'byá e, grande parte deles fala português fluente ou com pouco sotaque. O costume de união entre os membros das famílias ou com parentes de outras aldeias é mantido nos moldes tradicionais e, se um índio ou índia se casar com branco é afastado da comunidade, podendo visitar os parentes a qualquer tempo, porém não mais fará parte da comunidade.

Um dado interessante sobre essa aldeia pode ser notado ao se comparar a população que foi constatada por Ladeira (1984), entre 120 e 140 índios, e a população atual de aproximadamente 600 índios. Isto é, em 20 anos a população praticamente quintuplicou.

Os Guarani denominam como tekoa os locais onde formam seus assentamentos familiares (as aldeias). O significado de tekoa é, "modo de ser, de estar, sistema, lei, cultura, norma, comportamento, costumes". Pode-se dizer que seria o lugar qualificado como sendo aquele que reúne as condições básicas para o "modo se der" dos Guarani. 
A Área Indígena Guarani da Barragem, na década de 1970, era conhecida como "Vila Guarani". No início da década de 1980, a própria comunidade alterou o nome para "Morro da Saudade". Recentemente a comunidade escolheu uma nova denominação para a aldeia Tekoa Tenonde Porã. A origem dessa escolha se deu baseado no grupo de canto e dança Tenonde Porã, que é formado por crianças da aldeia. Segundo o índio Valdevino Veríssimo, o significado desse nome é "luz e esperança" ou "aliança para o futuro".

\subsection{Considerações adicionais sobre o presente capítulo}

Uma visão de conjunto relativa ao passado/presente pode ser uma forma didática para entender que os Guarani são sobreviventes de uma destruição radical de uma cultura. Independente de sua aculturação, para usar o termo de Egon Schaden (1969), sabe-se que em toda cultura dominada, embora se "aculture" com o passar do tempo, sempre sobrevivem fatos culturais, enquanto existirem viventes daquela cultura.

Ora, pergunta-se: mas será a cultura guarani uma cultura dominada?

A maneira pela qual se configura um conhecimento dentro de um "modus" cultural, não é o que caracteriza que o conhecimento tenha se perdido ou se "aculturado", porém uma reorientação do "modelo" de vida e uma acomodação são inevitáveis. Hoje, as aldeias que possuem antena parabólica e, computadores com acesso à rede mundial, são de fato uma realidade. Porém, ainda existem os conhecimentos tradicionais que foram transmitidos entre os índios e que ainda não se perderam, estão presentes no pensamento dos mais velhos e podem ser repassados para outros membros da mesma etnia. 


\section{MATERIAL E MÉTODOS}

\subsection{Origem dos dados}

Os dados iniciais e que serviram como base para a elaboração do projeto de pesquisa que são apresentados neste trabalho, foram gerados a partir de levantamentos realizados pelo próprio autor entre os anos de $1999 \mathrm{e}$ 2000, em diversas visitas a quatro aldeias Guarani: Morro da Saudade, Krucutu, Jaraguá e Aguapeú.

Antes mesmo de compor o projeto de pesquisa para o mestrado, o levantamento de dados a respeito do conhecimento que os Guarani possuem sobre as abelhas sem ferrão, embora retratado de forma genérica e substancialmente menos sistematizado, foi apresentado como parte integrante dos requisitos para a obtenção do título de Bacharel em Ciências Biológicas, sob orientação dos Prof. Dr. Paulo Nogueira-Neto e aconselhamentos metodológicos do Prof. Dr. Darrell Adson Posey, Prof. Dr. Eraldo Medeiros Costa-Neto e Profa. Dra. Nobue Myazaki. Gerou também duas diferentes publicações em dois eventos: $3^{\circ}$ Simpósio Brasileiro de Etnobiologia e $4^{\circ}$ Encontro Sobre Abelhas, ambos em 2000.

\section{2 Área de estudo}

A "Área Indígena Guarani da Barragem" (Anexo D), onde se encontra a aldeia Morro da Saudade se localiza no distrito de Parelheiros, 
bairro Barragem, periferia da cidade de São Paulo, estado de São Paulo, Brasil (coordenadas de latitude: S-2352'16" e longitude: W$\left.46^{\circ} 38^{\prime} 58^{\prime \prime}\right)^{35}$, restringindo-se a apenas 26,3 hectares. Embora esteja localizada no perímetro da Reserva da Biosfera do Cinturão Verde da Cidade de São Paulo (UNESCO, 1994), apresenta-se descaracterizada, contendo apenas pequenas manchas de mata nativa que somadas resultam em menos de dois hectares de áreas não contíguas.

A aldeia está inserida em Área de Proteção e Recuperação dos Mananciais (lei estadual 9866/77), na Bacia Hidrográfica da Billings (Figura 4) e, também está no perímetro da área da Área de Proteção Ambiental - APA Municipal Capivari-Momos (lei municipal 13.136/2001), que engloba parte das bacias hidrográficas do Guarapiranga e da Billings e, toda a bacia hidrográfica do Capivai-Momos. A área da APA se sobrepõem às áreas das aldeias Morro da Saudade, Krukutu e uma parte da área da aldeia Rio Branco. Todas formadas por Guarani-M'byá.

35 Dados obtidos a partir de: "elipsóide international de hayford datum horizontal = Córrego Alegre - MG - Brasil" 


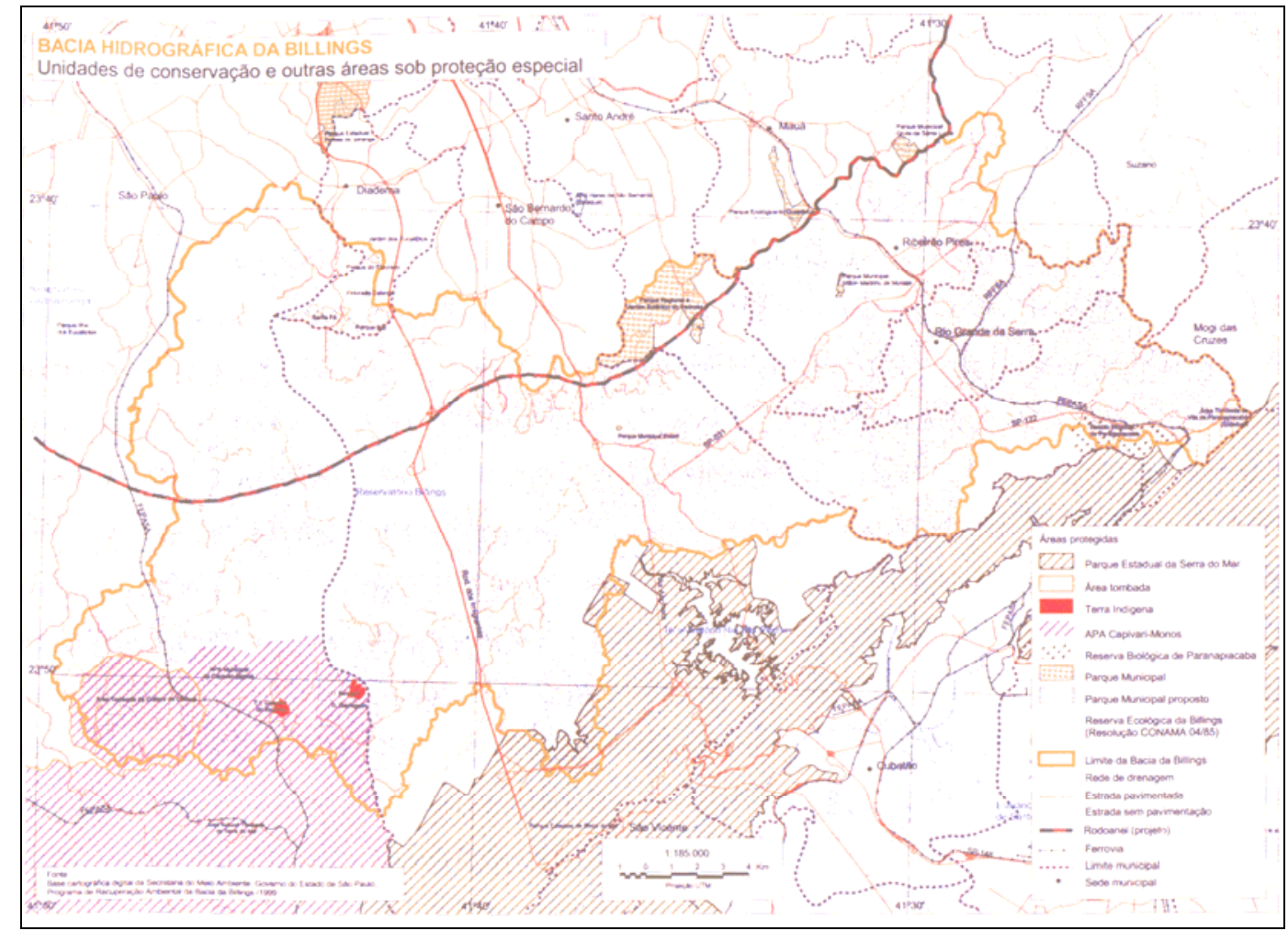

Figura 4 - Mapa de localização: aldeias Morro da Saudade e Krukutu Fonte: modificado de Capobianco \& Whately (2002)

Para se chegar à aldeia (a partir do bairro de Interlagos), segue-se pela Av. Senador Teotônio Vilela até Parelheiros. A partir da igreja matriz de Parelheiros, à esquerda na estrada da Colônia, por cerca de $5 \mathrm{~km}$, até o centro do bairro, segue-se pela estrada da Barragem, por cerca de $7 \mathrm{~km}$, até a Rua João Lang. A cerca de $300 \mathrm{~m}$ da entrada da Rua João Lang, a divisa com a área da aldeia, e a cerca de mais $300 \mathrm{~m}$ encontra-se a placa com o endereço indicativo da entrada da aldeia. Outra entrada se faz pela estrada da Barragem, após a passagem da Rua João Lang, aproximadamente $600 \mathrm{~m}$ adiante.

Os limites da aldeia são a norte (seguindo para o leste), uma propriedade privada; desse ponto a leste seguindo para o sul, o limite se dá com um braço bastante assoreado da Represa Billings, que serve de reservatório de água para abastecimento de várias cidades da região 
metropolitana de São Paulo; desse ponto ao sul seguindo para oeste com propriedades privadas; e desse ponto para o ponto inicial com uma estrada municipal que liga o distrito de Parelheiros a chácaras, sítios e fazendas. $O$ perímetro é de $2.153,83 \mathrm{~m}$, a cota altimétrica verificada é de $747,00 \mathrm{~m}$.

$\mathrm{Na}$ área não havia água potável e, foram perfurados poços artesianos para atender a essa necessidade. Um lago artificial, próximo a um dos limites (sul/oeste), inicialmente tinha por objetivo manter uma criação de peixes e outros animais. Porém, por não apresentar profundidade adequada, não pôde atender ao objetivo proposto. Devido a esse erro técnico, a lâmina d'água não apresenta medida suficiente para manter a estabilidade da temperatura; no inverno a temperatura da água é muito baixa e no verão elevase demasiadamente, não oferecendo um ambiente propício para a criação de peixes.

A aldeia está organizada por habitações pequenas, como é tradicional entre os M'byá atuais (Figura 5). Embora pareça não apresentar uma "organização espacial", tais moradias estão dispostas de maneira que familiares mais próximos formam pequenos núcleos que se comunicam facilmente. A casa de rezas (opy) (Figura 6), é facilmente acessível de qualquer ponto da aldeia e os caminhos que saem todos das habitações familiares, passam por pequenas plantações de milho e mandioca, as vezes também de feijão, quase sempre se vê pés de banana por perto das moradias. As construções das moradias são pequenas, com cobertura em "duas águas" feitas em troncos de madeira da própria região, geralmente eucaliptos. Em poucos casos, verificam-se finos troncos de madeira nativa. As paredes, formadas por taquaras amarradas por cipós e pequenos troncos são revestidos por barro, sendo fácil notar que algumas têm sobre o revestimento placas de madeira, folhas plásticas, geralmente de cor preta, e mesmo cobertores velhos, aparentemente cumprindo a função de tapar buracos. A cobertura é formada por sapé ou folhas de palmeira e o piso formado por terra batida. 


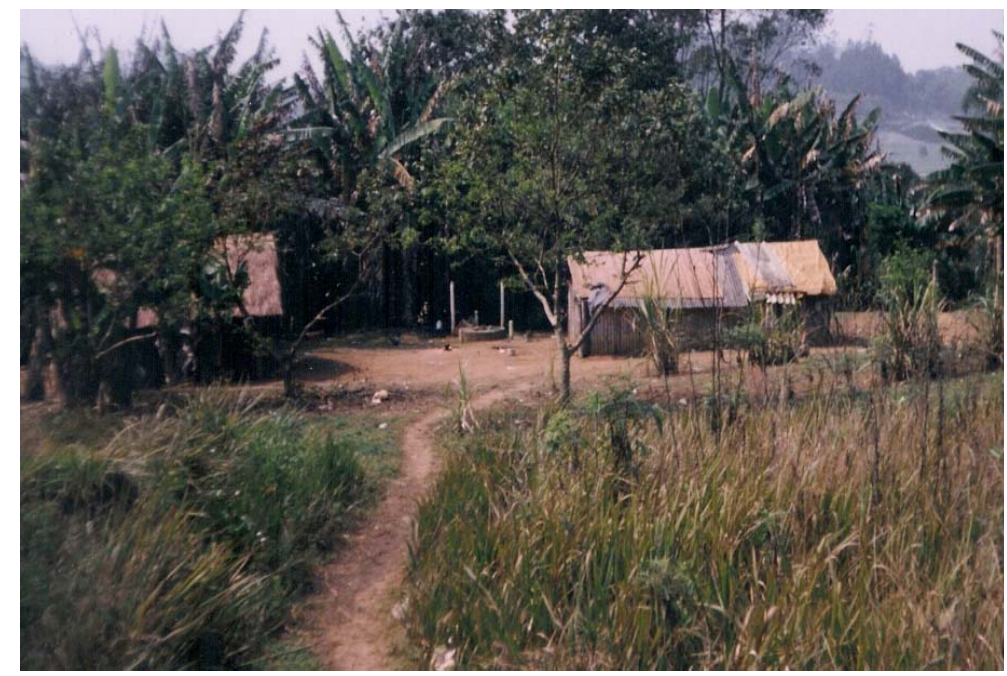

Figura 5 - Exemplo de moradias comuns na aldeia Morro da Saudade, atualmente

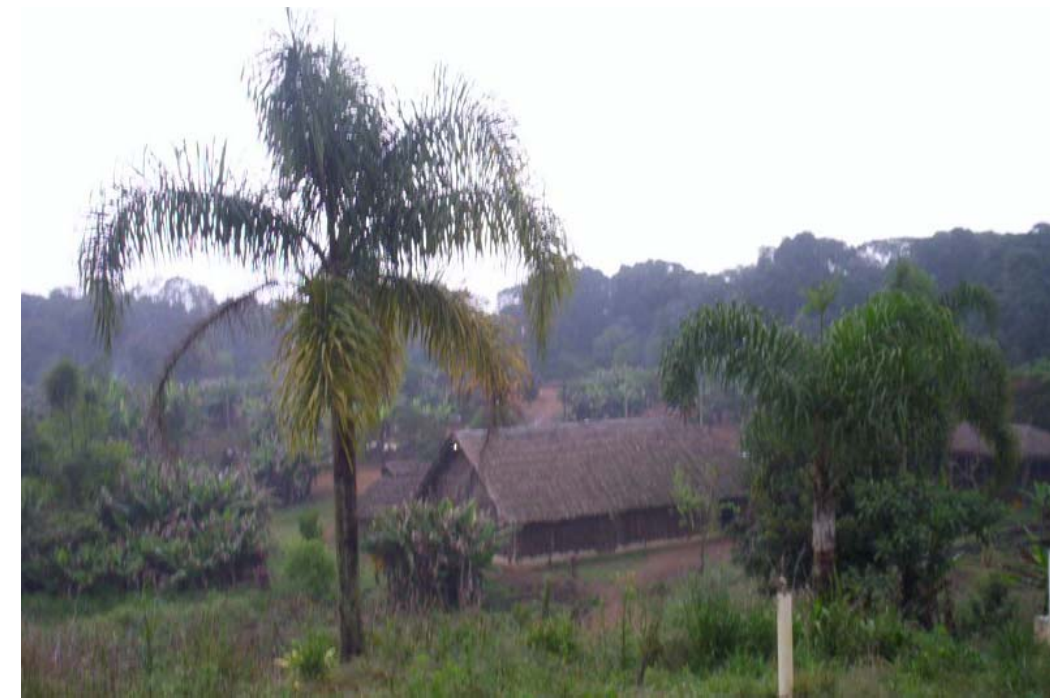

Figura 6 - OPY (casa de rezas)

Atualmente, vêem-se muitas construções cobertas por telhas de amianto e, em alguns casos, o sapé ou folhas de palmeira são cobertos por folhas plásticas ou folhas de zinco reaproveitadas. Muitas moradias começam a ser construídas em alvenaria ou misto, isto é, parte em alvenaria e parte na forma tradicional, como o exposto anteriormente. Uma justificativa para essa mudança é a falta de matéria-prima para a construção tradicional. 
A aldeia abriga várias construções em alvenaria para o uso comunitário: escola indígena, Guyra Pepó. Trata-se de uma escola vinculada à Escola Estadual de $1^{\circ}$. Grau, Belkice Magalhães Reis, onde professores da rede pública estadual se revesam com dois professores Guarani, que estão alfabetizando em idioma guarani. Enfrente à construção da escola é a sede de uma entidade indígena. Um posto de saúde, e uma sede cultural e comunitária.

Uma construção que chama muito a atenção, e que está próxima a uma das entradas da aldeia é a sede da antiga Rádio Tupã (pertencente à Rádio Tupi) que, está abandonada e, a construção está em péssimo estado de conservação. Já se falou, na comunidade, em recuperação da construção para a transformação do prédio em um centro de informações da cultura Guarani.

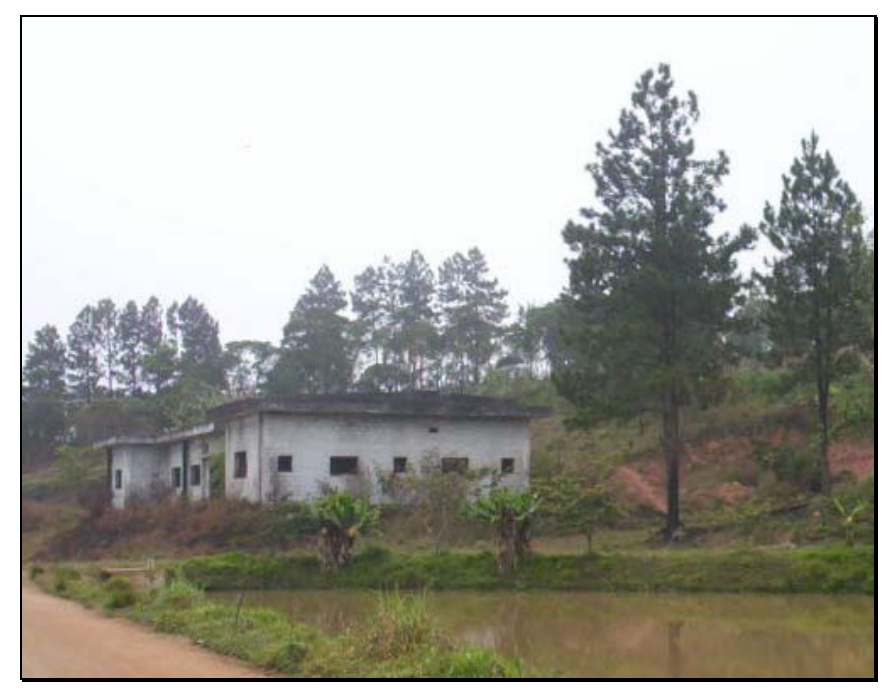

Figura 7 - Construção abandonada da antiga Rádio Tupã (no $1^{\circ}$. plano vê-se o lago artificial)

Espalhados em vários pontos da aldeia, próximo às moradias indígenas, verifica-se a construção de conjuntos de banheiros, com vasos sanitários e lavabos com instalações de água potável. Não há coleta de esgoto nem tratamento, sendo os dejetos lançados em fossas próximas aos banheiros. Todas as construções de uso comunitário são abastecidas com energia elétrica e água potável. Próximas às moradias existem instalações hidráulicas, torneiras e tanques para a lavagem de roupas. Toda a água usada na aldeia é 
bombeada mecanicamente por maquinário mantido por energia elétrica, para caixas d'água construídas pela Fundação Nacional da Saúde (FUNASA), podendo ser avistadas praticamente, de qualquer ponto da aldeia, destoando da paisagem. Dessas caixas saem os encanamentos para a distribuição para toda a aldeia. Em praticamente todas as moradias existem instalações de energia elétrica, usada para a iluminação e vários aparelhos domésticos. Televisores, rádios, aparelhos de som, geladeiras e máquinas de lavar podem ser encontrados nas moradias indígenas.

\subsection{População e organização da aldeia Morro da Saudade}

A população atual é de, aproximadamente, 600 indivíduos compondo cerca de 120 famílias. Não é muito nítido o núcleo familiar que reúne as casa de integrantes da mesma família extensa, tal ocorrência se dá devido a área ser muito pequena. Mas, a organização espacial com relação aos roçados e as casas, segue uma ordem, como foi descrito anteriormente, que é deteminada pelos moradores mais antigos, que segundo as informações dos próprios informantes, conservam suas moradias nos mesmos locais desde os anos de 1970.

Os índios moradores dessa aldeia são falantes da língua Guarani, do tronco lingüístico Tupi, da família Tupi-Guarani, de dialeto M'byá ${ }^{36}$. Quase toda a população da aldeia fala com fluência a língua portuguesa do Brasil. No entanto, antes de aprenderem o idioma português, aprendem o guarani-m'byá com os pais e outros parentes. Normalmente, entre eles, não é usual falar o idioma português.

O cacique é a autoridade maior da aldeia, representa os interesses da comunidade internamente e, junto à sociedade nacional. $O$ atual cacique Timóteo da Silva Vera Popygua, foi indicado pela comunidade em 2003, substituindo o antigo cacique Karai Poty (Manuel Lima) que ocupou a função de cacique desde 1997.

36 De acordo com os lingüistas Rodrigues (1994); Montserrat (1994) e Teixeira (1995) o "M'byá" é um entre os dialetos do idioma Guarani, os outros são: Chiripa/Nhandéva e Kayowa. 
A aldeia preserva alguns papeis e funções que estão relacionadas exclusivamente às questões internas, como uma chefia espiritual que é desempenhada por Kunhã Karai Pará Poty (Virgínia Veríssimo) e, pelo pajé Guirapepo Karai Poty (José Fernandes Soares), que atualmente vive na aldeia do Jaragua.

\subsection{Critérios que indicaram a área de estudo}

A Aldeia Morro da Saudade foi escolhida como área de estudo para este trabalho por apresentar algumas características que foram consideradas relevantes para se atingir os objetivos do estudo, tais como: sua localização e proximidade da cidade de São Paulo, a apenas $50 \mathrm{~km}$ do centro da cidade $^{37}$, em sua periferia. Seus habitantes são todos índios Guarani ${ }^{38}$, procuram manter a endogamia, casam-se no mesmo subgrupo, mesma aldeia ou outra aldeia M'byá. A aldeia é ponto de passagem para vários grupos familiares que se movimentam de uma aldeia a outra, inclusive indo ou vindo de outros países como o Paraguai, Argentina e Uruguai. Praticamente toda a população é bilíngüe (guarani-m'byá e português do Brasil). Dados anteriores apontaram essa aldeia como local onde residiam especialistas em abelhas sem ferrão (Santos-Rodrigues; Alonso \& Nogueira-Neto, 2000).

\subsection{Metodologias e técnicas empregadas para a coleta dos dados}

Os dados apresentados neste trabalho foram obtidos a partir da participação do autor na vida cotidiana da aldeia, por meio de várias visitas, mais de 90, entre os anos de 1999 e 2000 e entre 2002 e 2004, que incluíram etapas distintas:

- Permanecer na aldeia apenas observando os seus moradores sem participar de qualquer atividade;

37 Marco Zero, localizado na Praça da Sé, ponto central da capital paulista.

38 Exceção ao operador da bomba d’água, que é uma família mestiça guarani+branco, que embora tenha essa mistura foi aceito na aldeia por causa de sua operacionalidade com relação ao abastecimento de água potável da aldeia. 
- Conversar informalmente com os moradores da aldeia sobre assuntos não ligados aos objetivos da pesquisa;

- Acompanhar atividades onde estavam presentes outros não índios e conversar informalmente com os índios sobre assuntos que não estavam ligados aos objetivos da pesquisa;

- Conversar com as lideranças a respeito de cerimônias que iriam ocorrer e sobre a possibilidade de fazer algumas perguntas para os moradores sobre alguns animais que eram criados na aldeia, como galinhas e alguns cachorros;

- Acompanhar os índios em diversas atividades como as conversas que mantinham entre eles e a preparação para algumas reuniões, festas e cerimônias, reuniões com a FUNAI, com o Ministério Público, Comissão de Direitos Humanos e outras organizações.

Durante essa etapa, em nenhum momento foi falado aos índios a respeito de abelhas ou qualquer coisa que lhes pudesse induzir a falar sobre abelhas, mel ou qualquer produto que estivesse ligado a essa questão.

Após obter o consentimento do cacique para desenvolver uma pesquisa sobre os costumes dos moradores da aldeia, iniciou-se a fase de etnografia com anotações dos dados observados (Geertz, 1978). Tal opção metodológica foi decorrente do entendimento de que tais procedimentos seriam benéficos para iniciar a coleta sistematizada sobre o conhecimento das abelhas por aqueles índios.

Como as anotações de campo, por mais independentes e imparciais que possam parecer, sempre apresentam a influência do pesquisador, seja consciente ou inconscientemente, é preferível acreditar que, à medida que se desenvolve a pesquisa de campo os dados já estão sendo interpretados e o que se faz ulterior ao coletado, pressupõe uma análise mais contextualizada. 
O estudo etnográfico permitiu que se conhecesse a comunidade de maneira preliminar, porém metodológica, suas relações com o ambiente num sentido amplo, incluindo-se o relacionamento entre os próprios habitantes, entre eles e os parentes que os visitam invariavelmente, entre outros membros da mesma etnia que passam pela aldeia, mas que não são parentes, e mesmo entre esses índios e outros índios de outras etnias, que visitam a aldeia. Muitas vezes, neste caso, a língua falada entre os dois povos é o português do Brasil. Também se observou o relacionamento entre os índios e os brancos: pesquisadores, religiosos, membros de entidades filantrópicas, praticantes do futebol de campo que freqüentam a aldeia nos finais de semana, vendedores de diversos produtos que passam pela aldeia tentando comercializá-los, políticos, policiais, dentre outros, e os próprios funcionários da FUNAI. Foi por intermédio de uma prática de observar e se deixar ser observado, que se adentrou com mais facilidade aos meandros na rotina da aldeia, sendo convidado a participar de várias atividades.

Essa etapa também possibilitou uma melhor compreensão de dados obtidos através da pesquisa bibliográfica a respeito dos Guarani M'byá. Embora se possa reconhecer que se empregou um tempo relativamente longo nesse primeiro momento da pesquisa, por outro lado, o pesquisador sente-se seguro ao fim de uma relação que substancialmente lhe permitiu entender com mais detalhes a vida na aldeia, e ser convidado a participar de muitas atividades, algumas em que os juruá ${ }^{39}$ (brancos) não são aceitos.

A partir do início do mestrado, os levantamentos de dados obedeceram ainda a duas etapas de coletas de campo que se distinguem qualitativamente, porém se completam. A primeira, de observação-participante, que segundo Kluckholm (1946), tem como propósito obter dados sobre o comportamento da etnia pesquisada, através de contatos diretos, em situações específicas ou não, nas quais a intervenção do investigador é reduzida ao

39 Juruá quando considerado em sua tradução literária, significa "boca com cabelo", Ladeira (1992) explica que essa tradução está ligada ao contato inicial dos Guarani M'byá com os portugueses e espanhóis conquistadores. Não se sabe ao certo desde quando esse termo passou a ser usada, porém ele é um termo genérico usado por esses índios ao se referirem aos brancos, aos não-índios. 
mínimo, pois ele mesmo participa dos acontecimentos ao observá-los. E a segunda, de entrevistas livres e entrevistas semi-estruturadas aplicadas a vários membros da comunidade. Tais entrevistas seguiram um roteiro préestabelecido com o intuito de garantir o máximo de homogeneidade no que se refere à abordagem (Anexo B). Segundo Haguette (1992), o roteiro de entrevistas, faz parte do processo de interação entre o entrevistador (que no caso deste trabalho foi o próprio pesquisador) e o entrevistado (que no caso deste trabalho, além de vários moradores da aldeia, os "informantes-chave" ou "especialistas" cumpriram essa designação). Para Haguette (op.cit.), o roteiro de entrevistas, que também pode ser denominado como "o instrumento de captação de dados", consta "... de uma lista de pontos ou tópicos previamente estabelecidos de acordo com uma problemática central e que deve ser seguida".

Em ambas as etapas, a utilização da abordagem êmica prevaleceu, objetivando coletar dados que possibilitassem centrar as coletas posteriores em um assunto específico. Tal abordagem resulta em registrar a maneira como os índios organizam, percebem, usam e transmitem seus conhecimentos sobre as abelhas sem ferrão, com o cuidado de não lhes impor os parâmetros científicos do pesquisador (Posey, 1983).

As entrevistas ocorreram por meio da técnica de entrevistas livres e semi-estruturadas. Segundo Viertler (2002), as primeiras ocorrem a partir de um diálogo livre entre o pesquisador e o informante, onde não existe um roteiro estruturado; as entrevistas semi-estruturadas, também denominadas de parcialmente estruturadas (Viertler, op. cit.), são aquelas em que parte dos tópicos são previamente fixados, enquanto outros são "(...) redefinidos conforme o andamento da entrevista visando canalizar o diálogo para as questões a serem investigadas". Neste caso, conversa-se com os entrevistados tendo como base uma lista de tópicos previamente elaborados. Minayo (1998), define as entrevistas semi-estruturadas como as que formam uma articulação entre aquelas que são estruturadas e as não-estruturadas. Isto é, as entrevistas semi-estruturadas apresentam possibilidades e abertura para que, 
em sua aplicação, possa ceder espaço para novas estruturas se o pesquisador sentir tal necessidade, podendo ainda apontar para que se trabalhe a elaboração de material estruturado para aplicar no campo, no mesmo entrevistado ou em outros.

Em ambos os casos, o grau de formalidade variou bastante, desde a simples conversa que ocorreu em ambientes abertos, em volta do campo de futebol, em áreas desocupadas do entorno das moradias indígenas, nas roças de milho, nas caminhadas pela aldeia, na frente do centro comunitário, escola, associação, posto de saúde, na porta das moradias, até em ambientes formais, onde a apresentação de motivos também era formal, como, em reuniões de lideranças dentro da casa de rezas e nas próprias moradias com os moradores e seus parentes visitantes da aldeia.

A "metodologia geradora de dados", que consiste basicamente em permitir que o próprio informante proponha tópicos e explicações para o assunto em questão, é segundo Posey (1986a) uma técnica com a qual se corre menos riscos de prejudicar as informações. Essa foi uma técnica aplicada inicialmente logo nos primeiros contatos com os índios, num relacionamento informal e formal, às vezes complementado pela formulação de perguntas abertas ${ }^{40}$, para dar chance de respostas bem abrangentes e em que os entrevistados ficassem bem à-vontade para falar. Tal escolha reflete a preocupação do pesquisador em não questionar, simplesmente, para o que Posey (op. cit.), chama a atenção, indicando que tal procedimento "conduz à inibição do fluxo de informações por parte do informante". Com essa metodologia, pode-se descobrir palavras e expressões usadas no dia-a-dia e que serão usadas para a formulação de outras perguntas, facilitando a comunicação entre as partes.

40 A que se deixar claro que uma das metas da pesquisa etnobiológica, é exatamente minimizar exaustivamente o impacto que o questionamento sobre qualquer assunto, pode causar ao andamento e evidentemente, aos resultados da pesquisa. O pesquisador busca um envolvimento quanto maior melhor com os dados que lhes são transmitidos pelos informantes. É uma metodologia de condução da pesquisa de campo, onde se tenta "ser conduzido/conduzindo", parafraseando Morin (1980), fugindo da simplista interrogação sobre o assunto que se pretende estudar. 
No momento inicial, a abordagem foi dirigida a qualquer indivíduo da aldeia, mesmo porque não se tinha um perfil de quem eram os conhecedores do assunto. Os dados obtidos sobre abelhas (quaisquer dados) indicavam sempre que ali na aldeia existiam "especialistas", visto que praticamente toda comunidade indicava dois irmãos como sendo as pessoas que conheciam mais o assunto. Houve a insistência em conversar com os mais antigos moradores da aldeia e com os índios mais velhos, homens e mulheres, além de jovens e crianças que acabavam sempre indicando as mesmas pessoas para falar sobre o assunto.

Ao se dirigir aos informantes, considerados neste estudo como "informantes principais", o mesmo que Martin (1995) denomina como "informantes-chave" que, segundo o autor, são informantes que têm um profundo conhecimento de aspectos particulares de uma cultura local, também denominados como "consultores culturais" por Posey (1986a), já se sabia que ali na aldeia há cerca de dez anos, de acordo com Santos-Rodrigues; Alonso; Nogueira-Neto (2000), estavam instaladas algumas caixas de abelhas sem ferrão de responsabilidade de um dos dois irmãos indicados como especialistas nesse assunto.

Os especialistas foram então encontrados e consentiram em colaborar com o estudo falando livremente sobre as abelhas e o próprio mundo dos Guarani, onde e como elas se situavam, os costumes e o conhecimento que Ihes haviam sido transmitidos por outros índios. Aliás, o assunto foi tratado de maneira espontânea, o que remetia ao tema sem influenciar a qualquer tempo sobre as opiniões declaradas. Quando o assunto se voltou ao tema central, objeto do projeto de pesquisa para o mestrado, o diálogo, às vezes em forma de inquirir o informante, passou a ser dirigido especificamente para essa questão, desenvolvendo-se especificidades relacionadas com a biologia, ecologia, distribuição e aproveitamento indígena sobre as abelhas sem ferrão e seus produtos. Deu-se ênfase ao tema, porém sem se restringir a ele com exclusividade, permitindo ao informante falar a respeito de outros assuntos ou mesmo abordar o assunto de outra maneira, demonstrando ao informante que 
todos os assuntos eram pertinentes, toda a atenção era voltada para as informações, e todas elas mereciam atenção.

Um dos irmãos considerado especialista em abelhas não residia mais naquela aldeia o que levou o pesquisador a passar alguns dias acampado em outra aldeia (Aguapeú) a fim de coletar informações a respeito do assunto.

Baseado no método anteriormente aplicado por Camargo \& Posey (1990) com os índios Kayapó, a partir do momento em que foi identificado o especialista passou-se a conversar com ele, formal e informalmente, acompanhando-o em caminhadas pela aldeia e mesmo visitando outras aldeias em sua companhia, participando de rodas de conversa com outros índios (alguns que não falavam o idioma português), participando de festejos e rituais cerimoniais, sempre que convidado. Nunca, porém se desprezou a possibilidade de falar sobre o assunto com outros membros daquela comunidade.

Os dados foram sendo tabulados à medida que se obtinham informações e eram contextualizados entre as informações anteriores. Muitas vezes, solicitava-se ao informante que comparasse dados diferentes para esclarecer dúvidas que, por ventura surgiam ao se reverem os assuntos.

O próprio informante, neste caso o informante-chave, para elucidar algumas de suas explicações a respeito da arquitetura dos ninhos das abelhas sem ferrão, ofereceu-se espontaneamente, para desenhar o interior do ninho. O resultado foi analisado (cognição comparada, [cf. Marques, 2001]) juntamente com o esquema de ninho de abelhas sem ferrão (Nogueira-Neto, 1970).

As palavras do idioma guarani-m'byá foram confrontadas e confirmadas no vocabulário Guarani/Português (Dooley, 1982) com a finalidade de esclarecimento de dúvidas, sendo que muitas vezes o Prof. Dr. Waldemar Ferreira Neto foi consultado sobre palavras que não constavam no trabalho de Dooley (op. cit.). 
Por várias vezes, sempre acompanhado pelo informante-chave especialista em abelhas, foram visitadas as manchas de matas da aldeia com a finalidade de encontrar alguma espécie de abelha sem ferrão. Essa técnica, também conhecida como "turnê guiada" (cf. Marques, 2001), consiste em realizar incursões às áreas de interesse da pesquisa, sempre acompanhando ou acompanhado por entrevistados. Porém, tal prática foi sempre frustrada por não atingir seu objetivo. Desta forma, não foi possível encontrar as espécies citadas pelos informantes ou mesmo coletar espécimes para identificação taxonômica científica.

Após conversar sobre uma determinada etnoespécie, era solicitado ao informante que fornecesse a denominação em idioma português para a mesma, quando isso não acontecia espontaneamente. O procedimento sobre o uso de algum produto das abelhas obedecia à mesma regra. Se não era mencionado espontaneamente pelo informante, uma pergunta lhe era dirigida com relação à utilização de algum produto.

Não sendo possível avistar os ninhos ou espécimes das abelhas para o registro fotográfico e a captura de espécimes para a identificação científica, como havia sido sugerida no plano de pesquisa do mestrado, a comparação com a nomenclatura científica, para cada etnoespécie, foi realizada após os dados terem sido coletados integralmente e agrupados em uma tabela que continha apenas o nome da etnoespécie e as pistas taxonômicas descritas pelo informante. Tais dados foram apresentados ao Prof. Dr. Paulo Nogueira-Neto, do Laboratório de Abelhas do Departamento de Ecologia Geral do Instituto de Biociências da Universidade de São Paulo, que procedeu à análise comparativa entre os dados, apontando a provável nomenclatura científica. 


\title{
5 RESULTADOS E DISCUSSÃO
}

\subsection{A percepção e a importância das abelhas: alguns aspectos na formulação do pensamento a respeito do equilíbrio homem/natureza na concepção dos Guarani}

\begin{abstract}
A importância das abelhas e vespas no modo de vida dos índios Guarani apresenta-se com significativa participação. As abelhas estão relacionadas a diversas atividades culturais, à religiosidade, a atividades de pajelança e à manufatura de produtos de usos medicinais para o controle de determinadas doenças, prevenção de outras e também, cura de alguns males. No entanto, tem na alimentação um de seus principais usos, como veremos posteriormente.
\end{abstract}

Foi apenas no final do século XX que os índios Guarani passaram a usar a escrita de seu idioma para registrar as suas palavras e os seus pensamentos. Porém, isso não significa que o conhecimento indígena, a partir de então, foi registrado e passou a ser consultado por quem o quer saber. $\mathrm{Na}$ verdade, alguns índios passaram a escrever. Existem algumas publicações de contos e lendas da história dos Guarani, registradas em idioma português, escrito por índios Guarani da etnia M'byá. O conhecimento entre esses índios sempre foi transmitido de geração para geração, caracterizando-se por meio da oralidade principalmente na interação entre pais e filhos, ou ainda dos familiares mais velhos com os mais novos.

No caso do conhecimento sobre os insetos, mais especificamente neste estudo sobre as abelhas sem ferrão, abelhas com ferrão e algumas vespas, constatou-se que a transmissão do conhecimento também ocorria 
principalmente pela oralidade. Mas, ficou muito evidente que, ao acompanhar os mais velhos, observando o comportamento destes e, copiando suas ações, o conhecimento também era integrado, o que leva a afirmativa de que além da oralidade, as tentativas de acertos compunham o conjunto do aprendizado, para a assimilação desejada. Sendo que a prática, a utilização e a aplicação desse conhecimento envolviam, não apenas o saber, mas o reconhecimento dele pelos membros da família.

O informante Karai Poty explicou que recebeu de seu pai algumas tarefas relacionadas ao cuidado com as abelhas e, quando se tornou adolescente, Ihe foram dadas caixas e ninhos de abelhas para que pudesse cuidar e ampliar a criação. Tal procedimento, considerado comum pelo informante quando relacionado com os membros de sua família, pode indicar uma preocupação com a continuidade de determinado costume e de sua retransmissão, como também pode se revelar como indicativo de parte de um ritual de passagem, entre as idades de criança e adolescente.

Os integrantes da família mantinham um envolvimento em que o conhecimento, a ação e o sentimento interagiam, ocorrendo de forma imbricada. Fundamentalmente, a transmissão do conhecimento sobre as abelhas não ocorria ao acaso; o pai ao escolher os filhos que deveriam aprender a lidar com as abelhas, o fazia quando o filho era muito novo.

Quando a criança apresentava um ou dois anos de idade já era levava para ver como se cuidava das abelhas. Nas declarações de Karai Poty,

“... o pai tinha que levar a criança bem cedo pro mato, para ver as abelhas, pra que a criança sentisse o cheiro delas e do ninho e das árvores onde elas estavam, e já se acostumasse a escutar os zumbido e olhar os bichinhos nas plantas, nas flores, pra aprender a encontrar seus ninhos quando crescesse..." 
De um modo geral, os índios de mais idade, isto é, com mais de 45 ou 50 anos de idade, moradores ou visitantes da aldeia, se referem ao conhecimento adquirido sobre as abelhas como se fosse produto de uma fase importante do conhecimento do mundo que os rodeava na época em que aprenderam a lidar com esses insetos.

Entre os índios, mesmo aqueles que não haviam tido contato com as abelhas, ou seja, não manipulavam as colméias na natureza ou levadas para a aldeia, se referiam a elas ou aos seus produtos como se tal fato tivesse marcado uma fase de suas vidas, pois falavam entre eles de fatos acontecidos há mais de 30 ou 40 anos, sempre associando a outros fatos daquela época em que viviam, como, mudança de uma aldeia para outra, saída de parte de uma família e lembranças de entes queridos, alguns que já morreram ou que não eram vistos há algum tempo.

Em diversas oportunidades, em conversas informais, os índios teciam explicações sobre a floração ou as estações do ano como o verão ou inverno em que as abelhas aparecem em maior ou menor quantidade. $O$ entendimento sobre a sazonalidade das abelhas os remetia à possibilidade de que se estabelecessem regras sobre a retirada de qualquer produto produzido por esses insetos.

Analisando tais dados, pode-se afirmar que são indicativos de que essa ação se refere a um manejo ecológico realizado intencionalmente. Algumas espécies de plantas eram transferidas das matas para perto dos ninhos que já haviam sido instalados nas proximidades das moradias indígenas. Essa era uma ação que resultava no plantio de espécies vegetais em locais muito próximos das moradias, ou mesmo em um pequeno espaço reservado no terreno da moradia (meliponários), onde eram colocadas as caixas e troncos com os ninhos das abelhas.

O índio Karai Poty explicou que seu pai plantava perto da casa e dos ninhos algumas plantas que encontrava nas matas, de que as abelhas gostavam muito. Embora não tenha identificado as espécies de plantas usuais 
que seu pai escolhia para o plantio como o mencionado, declarando que não se recordava no momento em que se discutia o assunto, em suas explanações, alguns dados merecem destaque. Por exemplo, explicou que as plantas que seu pai escolhia sempre tinham flores e algumas tinham flores o ano inteiro.

Tais dados demonstram adiantado conhecimento sobre a floração mais adequada para o fornecimento de uma alimentação para as abelhas, além de fortalecer a idéia de um manejo sustentável para as abelhas na região, e ainda, a preocupação em oferecer uma melhor condição de recuperação dos ninhos mantidos sob sua responsabilidade, proporcionando uma opção de melhor custo-benefício para o desenvolvimento das abelhas em seu meliponário.

Posey (1987), sugere que o conhecimento que leva a essa prática pode ser útil para que se investigue a polinização das florestas tropicais. A essa hipótese, pode-se acrescentar que o próprio manejo da região, pode ser estudado a partir de dados obtidos sobre o plantio intencional de espécies florais em interface com a semidomesticação de abelhas polinizadoras.

Outro índio de idade mais avançada, Gumercindo, falando sobre flores numa caminhada entre uma aldeia e outra explicou:

"às vezes era bom pôr algumas mudas de planta por perto das abelhas. Sempre no próximo início de flores as abelhas iriam tirar o evorakue (pólen), para aumentar os ninhos, se a flor está por perto ela gasta menos tempo voando e não tem perigo de ser pega pelo passarinho".

Os informantes explicaram que no início da floração das plantas, os índios procuravam não retirar o mel ou qualquer outro produto das colméias, e muitas vezes esse costume estendia-se a algumas espécies de plantas. Também procuravam não retirar as flores das árvores, pois conforme a declaração do Karai Poty: 
“...é a época em que a natureza está renascendo e recomeçando, é a época em que as abelhas também acompanhavam essas fases de aparecimento de flores, era ai que elas aumentavam os ninhos. Isso já nos dizia que iam pôr mais crias e fazer mais mel. É um aviso da natureza para que esperássemos cada coisa acontecer em seu tempo. Assim, quando as abelhas saiam pela manhã, logo cedo e iam em algumas plantas do terreno, mesmo as que não tinham flores, já sabíamos que as flores iam surgir logo, e já sabíamos que a época de muito frio poderia estar acabando. Também aprendi que as abelhas não viviam sem as flores e que as flores não viviam sem as abelhas. Se você encontrar flor é porque tem abelha e se encontrar abelha é porque tem flor".

A percepção que os informantes têm das abelhas é de que elas são tão importantes para as flores como as flores o são para as abelhas. Fazem questão de explicar que as abelhas e as plantas fazem parte de algo maior onde eles, os Guarani, estão envolvidos e que tudo tem um tempo certo para acontecer. Portanto, conforme a declaração do índio Karai Mirim Poty, antigo morador da aldeia Morro da Saudade e que atualmente vive com sua família na aldeia Aguapeú:

“...quem conhece a natureza das coisas pode mexer nas abelhas e nas plantas. Muitas vezes as abelhas vão embora, é que os brancos chegam derrubando as árvores, cortando o mato. Eles não sabem nada e quando quem não entende nada desses bichinhos se mete a sabedor, espanta as abelhas. Algumas abelhas nunca mais voltam e muitas árvores também não". 
$\mathrm{Na}$ explicação dos Guarani, o ano é regido pelo sol (kuaray) e pela lua (jaxy). $\mathrm{O}$ ano é dividido em duas estações climáticas, o período quente ou verão (arapyau) e o período frio ou inverno (arayma). Quando surgir a primeira lua nova do verão, no mês de agosto, está se iniciando o ano. Os Guarani consideram que é um aviso de que está havendo uma renovação e que pode ser entendida pela expressão usada para identificar esse momento: ne'ē pyau como sendo um novo tempo, ou um início de um novo tempo. A tradução para o idioma português da expressão ne'ē pyau, pode ser "espírito novo", que o informante Karay Poty explicou que é "(...) quando está chegando o verão que o juruá (brancos), chama de primavera, as árvores começam a ter novas flores e folhas novas e isso sinaliza que toda a vida vai mudar (...)"

O conhecimento a respeito da manipulação das abelhas foi adquirido pelos informantes antes que eles migrassem para o estado de São Paulo. Karai Poty (principal informante) nasceu no estado do Paraná, na Área Indígena Rio das Cobras, no município de Laranjeiras do Sul, onde ainda vivem muitos de seus parentes diretos. Seu aprendizado como o de seu irmão Karai Mirim Poty, ocorreu acompanhando o pai, Karai Tata Endy, já falecido, que foi citado por vários índios de mais idade como sendo um grande especialista em abelhas.

A tradição em observar, entender, classificar, semidomesticar, extrair produtos e aproveitá-los no dia-a-dia dos Guarani, bem como em rituais específicos, tanto os realizados no dia-a-dia como alguns especiais e que são realizados apenas em algumas ocasiões, fazia parte da rotina de vida na aldeia onde nasceram e cresceram os principais informantes deste estudo.

Segundo declarações dos informantes, o pai do índio Karai Tata Endy e avô de Karai Poty, desde criança era um conhecedor paciente e dedicado. Foi ele, quem ensinou seu filho tendo, por sua vez, aprendido com seu pai, bisavô dos informantes.

Um dado de campo que pode ser considerado interessante é que entre todos os índios ouvidos, formal e informalmente, a primeira abelha citada espontaneamente quando se falava desses insetos, sem indução, pergunta ou 
qualquer atributo de condução especificamente para a questão das abelhas, foi a que os Guarani denominam como a etnoespécie jatei, que pela descrição e pistas etnotaxonômicas oferecidas pelos informantes, comparadas com a descrição científica, pode-se afirmar se tratar da abelha sem ferrão Tetragonisca angustula, conhecida popularmente como "jataí". Esta, segundo Nogueira-Neto (1997), é uma abelha muito comum, inclusive nos centros urbanos, mesmo nos dias atuais e sempre foi possível encontrá-las em território indígena dos Guarani.

Sabendo-se que os índios mantinham troncos de arvores com ninhos perto de suas moradias e que alguns ninhos eram trazidos e instalados em caixas para manterem as abelhas por perto, foi observada a forma como se realizava tal trabalho, os motivos e a quais resultados os índios chegavam. Karai Poty explicou que desde criança, quando acompanhava seu pai nas incursões pelas matas no Posto Indígena do Rio das Cobras, no município de Laranjeiras do Sul, estado do Paraná, tinha como objetivo trazer mel, cera, crias, ou mesmo ninhos inteiros. Para tanto, existiam certas técnicas que viu seu pai usar. Em outra fase de sua vida, passou a ajudá-lo, até o dia em que ele mesmo era quem realizava tais trabalhos.

Para a aquisição de colônias, saíam em caminhada pelas matas próximas à aldeia, procuravam por colônias matrizes que, eram ninhos fortes com grandes quantidades de abelhas e que já tinham favos de mel e de crias. Conforme sua explicação:

“... era muito importante escolher bem o ninho (eiro) que se queria retirar da mata. Se o ninho não está forte, então não vai adiantar, a abelha não agüenta mudar de lugar, acaba morrendo em pouco tempo. Se o ninho é bem forte você já sabe que além de ter o mel também terá os ninhos de crias. Ai é certeza que a abelha vai crescer, que o ninho não morre e 
logo você tem um ninho para tirar mel por muito, muito tempo"

Quando localizavam as abelhas, se elas estavam longe da colméia, uma das técnicas para encontrar as colméias era a de seguir seu vôo para chegar aos ninhos. Nogueira-Neto (1997), explica que o método de seguir as abelhas para a localização da colméia é um dos métodos mais documentados com relação ao Meliponineos. Hollanda ${ }^{41}$ citado por Nogueira-Neto (op. cit.), cita sete autores que fazem referência à técnica dos índios de localizarem abelhas dessa forma. Uma técnica similar, porém mais aperfeiçoada, para a mesma finalidade, é citada por Strelnikov (1928), e por Azara ${ }^{42}$ citado por Noelli (1993), que consiste em capturar um espécime de abelha e amarrar uma pluma de ave em seu corpo. Ao soltá-lo, ele pode ser seguido pelas sombras, no interior das matas, até a colméia. Litaiff (1999), refere-se à técnica em que os índios Guarani também amarram uma pequena pluma de ave em uma abelha para segui-la e encontrar sua colméia.

Muitas vezes, a localização do ninho se dava escutando o barulho ou sentindo o cheiro. Karai Poty explicou que sempre perto de um lugar onde tem abelha, o cheiro é diferente e segundo o informante: "de tanto você prestar atenção no mato, o mato parece que fala pra você o que você quer saber".

Uma vez encontrado o local onde as abelhas estavam instaladas, era realizada a retirada, o que era feito de várias maneiras. Os índios podiam retirar parte do tronco expondo o ninho que era cuidadosamente removido e colocado em uma caixa (yru) apropriada. Cortava-se com machado, facão, foice, enxada ou eram arrancados pedaços da madeira com as próprias mãos, ou ainda, o corte se dava com o uso de um serrote.

41 HOLLANDA, S.B. Caminhos e fronteiras. Rio de Janeiro: Ed. José Olympio, 1957. 334p. 42 AZARA, F. Geografia física y esférica de las Províncias del Paraguay y Misiones Guaraníes. Compuesta por Don Félix de Azara. Capitán de Navio de la Real Armada. Em la Asunción de Paraguay. Año de MDCCXC. Montevideo. Anales del Museo Nacional de Montevideo. v.1, 1904.610p. 
O informante explicou que as árvores velhas e muitas já mortas eram usadas pelas abelhas. Segundo ele, tudo tem muito sentido:

“...se a árvore fosse nova demais seria dura e difícil de cortar. Se a árvore estava morta secando, ou se tiver morrendo, então tudo era mais simples. Às vezes tinham mais que uma abelha (referindo-se à ocorrência de mais de uma colônia) no mesmo tronco, era melhor ainda...".

Ainda sobre a localização dos ninhos de abelhas, muitos fatores se somam ao conhecimento do nosso informante. Em uma ocasião foram enumerados vários dados ecológicos como a posição da luz solar, a incidência de espécies vegetais, as características do terreno, a umidade, o vento, a presença de determinados animais como macacos, corujas, esquilos, formigas, pássaros, entre outros. De fato, ao olhar fixamente para um trecho da mata, o informante realizou um levantamento minucioso, porém generalizado, daquele trecho, e quando avistou uma árvore seca, explicou que ali poderia ter abelhas. Mas, também explicou que com o sol e o vento que batiam naquele ponto, era certeza que nada se poderia encontrar. Além disso, indicou que o terreno estava muito aberto e provavelmente só um ninho muito fraco viveria ali, pois os passarinhos não deixariam, referindo-se à captura de abelhas por pássaros.

Para a retirada do ninho do tronco havia uma preocupação de cortar o tronco cerca de 40 a $50 \mathrm{~cm}$ para cima ou para baixo da entrada e saída das abelhas, dependendo da espécie de abelha que se estava retirando, uma vez que as abelhas usavam aproximadamente $40 \mathrm{~cm}$ do oco da arvore (yvyra kua), ou da madeira (yvyra), como o informante costumava se expressar ao se referir às arvores.

Essa preocupação se dava para que não se estragassem os favos (etãgue) com as crias (tayrai, embora também se referissem às larvas de abelhas como sendo a'yre) e aqueles com o mel (ei), ou com pólen (evorakue). As partes mais delicadas e que eram as que precisavam de um trabalho mais 
atencioso, eram retiradas com o auxilio de instrumentos apropriados, como uma pequena faca $(k y x e)$. Esse trabalho podia demorar muito tempo sem que pudessem sair daquele mesmo local. Ali mesmo se consumiam algum mel em favos. Porém a grande preocupação era a de transferir para a caixa anteriormente citada,

$$
\begin{aligned}
& \text { “...tínhamos que tomar muito cuidado e ter muita } \\
& \text { calma sobre a localização da abelha mãe de todas } \\
& \text { (ixy) (referindo-se ao que a ciência denomina como } \\
& \text { rainha). Essa é uma abelha diferente e delicada. Ela } \\
& \text { é maior e mais mole, anda pelo ninho quando a } \\
& \text { gente mexe na casa delas. Se você não tomar } \\
& \text { cuidado e perder ou machucar a mãe, vai ser muito } \\
& \text { difícil de dar certo; sem a mãe elas não } \\
& \text { acostumam". }
\end{aligned}
$$

Após a retirada do ninho e o acondicionamento na caixa, o procedimento era de retirar outros produtos que as abelhas usavam para recobrir o oco da árvore, sobre os quais o informante explica que:

$$
\begin{aligned}
& \text { “... serve para não deixar que entrem outros } \\
& \text { bichinhos e nem a umidade (...) com essa parede } \\
& \text { que elas constroem o ninho fica a salvo. Se fizer frio } \\
& \text { ou esquentar de mais não tem problema, o ninho } \\
& \text { com a família delas fica sempre igual”. }
\end{aligned}
$$

O informante se referia ao que a ciência denomina como cerume e que compõe parte da arquitetura interna do ninho. Segundo Nogueira-Neto (1997), o cerume é uma mistura de cera branca pura com resinas (própolis) que as abelhas retiram de arvores. Esse produto tem uma densidade apropriada que permite, em muitos casos, impermeabilizar as paredes internas dos troncos onde as abelhas se instalam. É considerado um produto muito importante, pois proporciona uma condição para que se mantenha um 
equilíbrio do meio ambiente interno e externo com relação à temperatura, ventilação, umidade, entre outros fatores.

Ao encontrarem um ninho no tronco, o procedimento também poderia ser o de cortá-lo e transportá-lo para a aldeia. Nestes casos, para a manipulação dos ninhos e retirada dos produtos das abelhas, o procedimento obedecia a várias precauções. Segundo o informante, uma das regras básicas era a de trazer o tronco sem bater demais pelo caminho e escolher um local que tivesse sol na quantia certa: “... se você colocar um tronco tirado do mato em um lugar que tem muito sol, as abelhas não gostam, às vezes tem que por na sombra mesmo...".

Encontrado o local adequado e após constatarem que as abelhas haviam se adaptado a ele, o que ocorria no mínimo cerca de três ou seis dias passados à instalação, o tronco era cortado longitudinalmente em relação ao posicionamento do ninho, transformando uma das partes em uma porta (ok), que deveria ser removida apenas para que se retirasse o mel ou algum produto necessário para a pajelança, ou para uso da família, em elaborações que se faziam necessárias para os rituais ou para a medicina tradicional.

$\mathrm{Na}$ explicação do informante os troncos poderiam ser abertos para que se pudesse observar como as abelhas estavam se adaptando, ou para mostrar a outro índio. Uma vez fechado, o troco era amarrado com cipó fino ou mesmo corda. De qualquer maneira, não abriam os troncos a qualquer hora. Isso ocorria preferencialmente bem no final do dia, quando as abelhas já estavam quase todas reunidas no interior do ninho, ou muito cedo, quando elas ainda não haviam saído para o campo. Segundo o informante, tal procedimento era mais aconselhável, pois quando mexiam nos ninhos num horário de muito movimento de entrada e saída de abelhas, elas ficavam "assustadas e voando para todos os lados, algumas morriam ali mesmo e caíam no chão na nossa frente, e se mexer sempre e na hora errada, a abelha pode ir embora".

Outra observação foi sobre a época do ano. No inverno, não se deveria mexer nas caixas ou mesmo nos troncos. Segundo as explicações do 
informante Karai Poty, as abelhas saem bem menos de suas casas no inverno e a rainha diminui muito a postura de ovos. Ele explicou que:

“...na natureza tudo é assim, no calor até o som da mata é diferente, no frio todos os animais ficam mais parados. Eles não podem andar demais e gastar energia. As abelhas precisam voar menos para gastar menos sua energia, comem menos por causa das plantas que estão sem flores. Aí elas vão comer o mel guardado para essa época e não podem ter muitos filhotes. Como elas ficam mais paradas e comem menos, o mel dura mais, ... se nessa hora nós tirarmos mais mel ou ficarmos abrindo a casa delas, elas vão morrer de frio ou de fome. Elas dormem mais tempo. Eu vi uma abelha (referindo-se à colméia) que diminuiu muito no frio. Estava numa caixa, ela ficou muito fraca e depois não conseguiu mais voltar a ser forte. Então não se deve mexer. Era uma jatei. Foi minguando e não passou pelo outro frio. Acho que foi de tanto mexer na caixa".

De fato as abelhas sem ferrão são habitantes naturais das regiões de clima tropical, sendo que o clima e temperatura constituem barreiras naturais para a sua distribuição. O testemunho e as explicações declaradas pelo informante quando confrontadas com os dados científicos (Nogueira-Neto, 1970 ; 1997), apresentam perfeita coerência e comprovam um conhecimento pormenorizado não apenas sobre as abelhas, mas sobre as questões climáticas da região. Sua comparação referindo-se a diversos animais, floração e atividades diversas das diferentes formas de vida na floresta local, é indicativa de que sua visão e entendimento do meio ambiente ou das abelhas especificamente, não ocorrem separadamente. Supõe que sua concepção da natureza apresenta-se de forma integrada, dando sentido holístico à sua forma 
de interpretar os fatos, e que suas respostas aos problemas encontrados para a semi-domesticação dos insetos em questão, obedece a uma análise que se caracteriza pela observação do todo focalizando a interdependência de vários fatores entre si, interligando-os para explicá-los individualmente.

Com relação à transferência das abelhas de um tronco para uma caixa, havia preocupação em deixá-la em local adequado para que a adaptação fosse a mais bem sucedida possível. O informante explicou que nestes casos as abelhas eram deixadas na caixa, que era colocada num local, de preferência definitivo e perto da moradia indígena, para que pudessem observá-la diariamente. Porém, tais observações obedeciam a muitas técnicas e deveriam ocorrer sem que as abelhas fossem perturbadas, “... para que a família (a colméia) aumentasse de tamanho e produzisse mais mel...".

Durante aproximadamente seis meses a caixa deveria permanecer naquele local, para que as abelhas se acomodassem e se adaptassem às condições desse novo local. Dessa maneira, segundo o informante, elas atingiriam um equilíbrio de produção que permitiria que se extraíssem o mel e outros produtos, sem por em risco a colméia. Mesmo assim era indispensável um trabalho delicado com os favos a fim de garantir sua integridade:

“...as bolinhas que estavam cheias de mel podiam ser retiradas em parte, uma parte delas devia ficar para que as abelhas sustentassem os filhotes e para elas mesmas poderem comer, (...) tinha que tomar muito cuidado para não correr o risco de machucar os favos com os filhotes que estavam em formação pois isso poderia por toda a colméia em risco. (...) O ninho tem partes que são muito molinhas, como se fossem folhas de papel, bem fininho. Para tirar as bolinhas com o mel deveria se escolher as que já estavam prontas, bem cheias, se você amassar as partes mais moles do ninho pode ser que estrague 
tudo. Essas coisas eu fui aprendendo devagar e não foi logo de cara que pude mexer com confiança. Meu pai me mostrava tudo e aos poucos eu fui aprendendo e fui mexendo. Demorou para que eu pudesse fazer essas coisas sem ele, eu já era crescido. Quando deixei de ser criança, (por volta de 10 anos de idade) meu pai me deu uma caixa de abelhas jatei, foi aí que comecei a ter que cuidar das abelhas. Meu pai me disse que eu tinha que cuidar delas sozinho e depois me deu mais abelhas. Com o tempo eu mesmo pude construir minhas caixas e apanhar as abelhas na mata; às vezes eu trazia o tronco inteiro e depois punha na caixa, ou deixava tronco mesmo em estado natural".

Os detalhes a respeito do interior do ninho, sua arquitetura e a ordem em que se encontrava cada uma das diferentes divisões, foi esquematizada espontaneamente pelo informante. Na oportunidade ele se ofereceu para desenhar um tronco de árvore contendo um ninho de abelhas sem ferrão, instalado em seu interior. A analogia realizada com o esquema da literatura científica (Nogueira-Neto, 1970), na acepção de uma cognição comparada proposta por Marques (2001), apresentou similaridade e equivalência, como pode ser visto a seguir: 

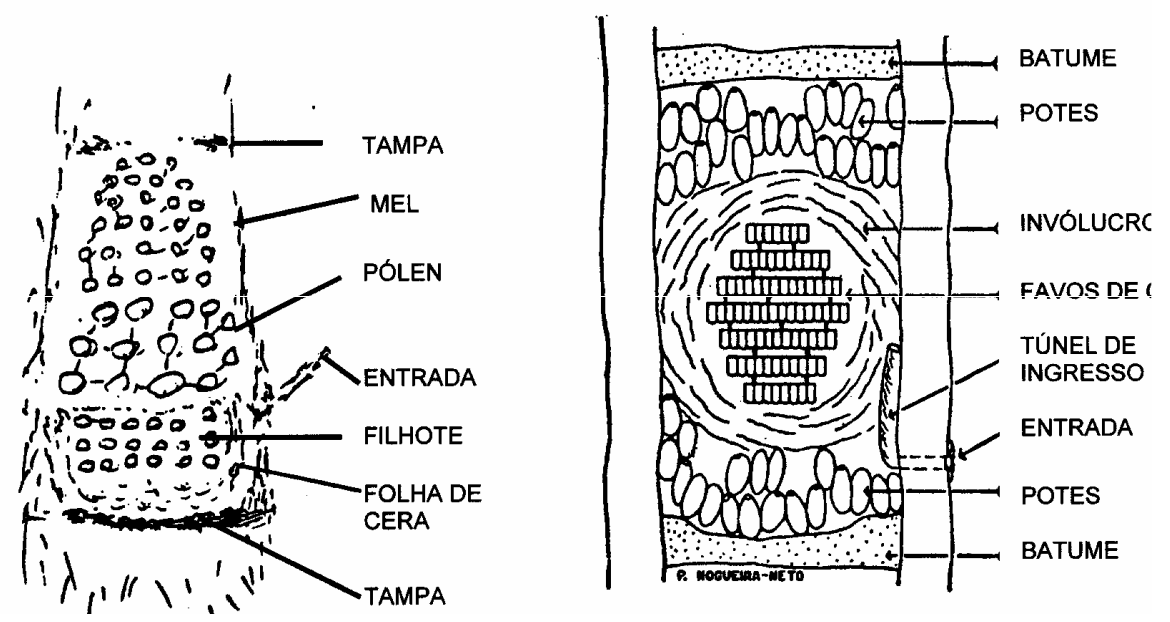

Figura 8 - A esquerda o esquema do ninho de abelhas sem ferrão produzido pelo informante-chave na mata próxima a sua moradia e a direita esquema de Nogueira-Neto (1970)

Algumas espécies de abelhas eram levadas para o interior da moradia, como por exemplo, as jatei. Karai Poty informou que essas colméias nas caixas e (ou) nos próprios troncos de origem, eram colocadas em qualquer local perto da casa, desde que não ficasse exposto diretamente ao sol o dia todo. Quando se tratava de troncos pequenos, colocava-os dentro da própria moradia, perto de uma janela ou da porta, pendurados por cipó ou por corda. Com as jatei que eram transferidas para as caixas também seguiam essa orientação, ou então, as abelhas eram colocadas no entorno da moradia.

Perguntado sobre o motivo que os levava a colocar as abelhas no interior da moradia e pendurado nas paredes externas, o informante argumentou que era para ficar perto de seus olhos e ao alcance a qualquer hora, ou ainda, para que pudesse ver todos os dias a hora que elas saiam para o campo e quando voltavam.

No entanto comparou diversas abelhas enumerando características antropomórficas para diferenciar as etnoespécies. No caso das jatei, a abelha mais citada pelo informante, explicou que era "boazinha e calma além de ser 
inofensiva, é dócil e não causa nenhum problema", atributos qualitativos positivos que o informante usou numa comparação com as ei guaxu que são as abelhas com ferrão, conhecidas popularmente por abelha "europa", cuja denominação científica é Apis mellifera. Para essas abelhas o informante usou atributos antropomórficos caracterizando-as negativamente em comparação às abelhas jatei:

$$
\begin{aligned}
& \text { “...essas são bravas, ficam esquisitas e estão } \\
& \text { sempre muito nervosas e de mau humor, sem } \\
& \text { motivo atacam a gente, essas são abelhas que } \\
& \text { nunca se pode colocar dentro da nossa casa, dentro } \\
& \text { de casa a jatei é uma abelha que sempre usei } \\
& \text { deixar em casa ela não é perigosa”. }
\end{aligned}
$$

Tal comparação coloca as duas etnoespécies em extremidades opostas, uma mansa e a outra brava. Mas chama a atenção o fato de tal comparação não acontecer para as abelhas nativas com ferrão, que como será visto mais adiante, são relativamente bem conhecidas do nosso informante.

Dessas informações pode-se inferir, num primeiro momento, que as abelhas com ferrão, no caso citado pelo informante as ei guaxu, são de tradição de muitos anos entre os Guarani, e que eram comuns na semidomesticação entre esses índios. No entanto é um grande engano pensar desta forma.

A etnoespécie que ele denominou como ei guaxu (Apis mellifera), foi uma espécie de abelha introduzida no Brasil, no Rio de Janeiro, pela primeira vez em 1839 pelo padre Antonio Carneiro Aureliano que as mandou vir da cidade do Porto, Portugal. Essas abelhas foram trazidas para os estados do sul, Rio Grande do Sul, Santa Catarina e Paraná somente em 1845, por colonizadores alemães que trouxeram consigo as abelhas $A$. mellifera da raça negra (Nogueira-Neto, 1972). 
Embora possuam ferrão, as abelhas que foram trazidas pelos colonizadores alemães, em 1845, também são conhecidas como relativamente mansas, isto é, menos agressivas e de fácil manipulação. Tanto isso é verídico que os colonizadores europeus mantinham por perto de suas residências caixas (cortiços) com essas abelhas ${ }^{43}$, geralmente no quintal das residências.

É bem provável que os Guarani começaram a enfrentar algum tipo de problema com relação à agressividade das abelhas com ferrão que eles denominam como ei guaxu, a partir da introdução das abelhas africanas, Apis melifera adansonii, no Brasil. Isso justificaria a conotação antropomórfica negativa observada a respeito das abelhas denominadas ei guaxu, quando o informante se refere a elas, em comparação às abelhas sem ferrão, que ele denomina como jatei, da qual a conotação antropomórfica, atribuída a espécie, é positiva.

A partir da tentativa do professor Warwick Kerr, que foi à África buscar abelhas africanas para cruzar com as abelhas italianas, tudo mudou com relação à apicultura no Brasil. Kerr citado por Nogueira-Neto (1972), expõe alguns detalhes sobre a introdução das abelhas africanas em território brasileiro:

“... fomos à África em 1956 e coletamos 170
rainhas. Dessas apenas 49 foram aceitas em
núcleos e colméias de Piracicaba, SP. Em 1957 foi
feito um experimento para testar as abelhas
africanas, as italianas e as pretas. Nada pode ser
concluído desse primeiro teste porque as abelhas
africanas tinham progredido tão rapidamente em 45
dias que 26 delas enxamearam. Esse foi um
acontecimento inteiramente fora do programa
traçado, pois não se tinha cogitado de dar a
ninguém linhas puras de Apis mellifera adansonii,

43 Essas caixas eram chamadas de cortiço justamente por serem originárias da arvore da cortiça vindas da Europa. 
mas somente os cruzamentos já segregados de italianas com africanas".

Nogueira-Neto (1972), considera que a entrada das abelhas africanas no Brasil marca o início de uma nova fase para a apicultura. Segundo o autor, o ano de 1957 marcou o fim da criação amadora das Apis, iniciando-se a fase de predomínio da apicultura técnica. Muitos criadores que mantinham suas colméias em cortiços abandonaram essa prática devido à falta de equipamentos para tratarem das abelhas que rapidamente se transformariam de "abelhas mansas" em "abelhas agressivas". A partir da introdução das abelhas africanas no Brasil, para se mexer nas caixas de abelhas, as pessoas precisariam usar mascaras, luvas e roupas especiais, ou poderiam ser ferroadas numa quantidade de picadas que poderia colocar sua vida em perigo.

Embora o informante tenha se referido à captura e transferência das abelhas do estado natural para o seu domínio, como sendo um procedimento muito parecido para todas etnoespécies, ao lhe perguntar diretamente se em algum caso, "para alguma abelha" havia um tratamento diferente, ele declarou que algumas davam mais trabalho, pois os ninhos eram mais difíceis de serem encontrados como era o caso das abelhas ei raviju. Espontaneamente explicou que os brancos denominam as ei raviju de "mandaçaia". Segundo sua exposição, essa abelha:

“...tem um ninho mais escondido, tem uma abelha só na porta, e fica escondida você não vê. Só quando uma abelha sai ou chega outra é que se vê que tem movimento. Por isso você tem que olhar muito mais para ver onde elas estão. O ninho é uma bola dentro do tronco e se você colocar com cuidado na caixa, se a rainha está lá, acabou o problema. As outras abelhas vêm e começam a criar. Elas sempre preferem ficar em troncos de madeira que está deteriorada." 
É interessante ressaltar que as informações obtidas a partir da pergunta anterior não se referiam direta ou indiretamente às abelhas ei guaxu (A. mellifera), que se apresentam como abelhas de difícil manipulação, como já foi esclarecido. Mesmo levando em conta as características antropomórficas evidenciadas pelo informante comparando as etnoespécies jatei com ei guaxu, (Quadro1), supõe-se que seus conhecimentos a respeito destas últimas ultrapassam apenas tal comparação.

\begin{tabular}{|c|c|c|c|}
\hline etnoespécie & $\begin{array}{c}\text { aspectos } \\
\text { antropomórficos } \\
\text { positivos }\end{array}$ & etnoespécie & $\begin{array}{c}\text { aspectos } \\
\text { antropomórficos } \\
\text { negativos } \\
\end{array}$ \\
\hline \multirow{2}{*}{ J } & boazinha & \multirow[t]{2}{*}{$\mathbf{E}$} & brava \\
\hline & Calma & & nervosa \\
\hline \multirow{2}{*}{ A } & Mansinha & \multirow[b]{2}{*}{$\mathbf{G}$} & furiosa \\
\hline & $\begin{array}{c}\text { gosta mais do ser } \\
\text { humano }\end{array}$ & & $\begin{array}{c}\text { não gostam do ser } \\
\text { humano }\end{array}$ \\
\hline \multirow[t]{2}{*}{$\mathbf{T}$} & Dócil & \multirow{2}{*}{$\mathbf{U}$} & danada \\
\hline & $\begin{array}{c}\text { não causa nenhum } \\
\text { problema }\end{array}$ & & esquisita \\
\hline \multirow[t]{2}{*}{$E$} & Inofensiva & A & de mau humor \\
\hline & não é perigosa & $x$ & \\
\hline \multirow{2}{*}{$\mathbf{I}$} & Esperta & $\mathbf{U}$ & \\
\hline & Valente & & \\
\hline
\end{tabular}

Quadro1-Características antropomórficas declaradas pelo informante, espontaneamente, para a comparação entre as etnoespécies jatei e ei guaxu

A partir de tais considerações são formuladas as seguintes hipóteses: a) as abelhas estão divididas em categorias diferentes, além dos atributos qualitativos de domínio biológico e comportamental; b) no domínio etnozoológico a abelha ei guaxu não está incluída na categoria das abelhas.

Para esclarecer tais proposições, primeiro perguntou-se diretamente se também havia captura para as ei guaxu e se o procedimento era igual ao das jatei. O informante de imediato esclareceu a hipótese b) explicando que: 
“...as abelhas ei guaxu não são a mesma coisa que as outras. Elas tem ferrão e picam podendo até matar uma criança, ou uma criação, cachorro ou outro animal, até os mais grandes. Existem várias abelhas: com ferrão e sem ferrão, são diferentes demais, não só o ferrão, mas o jeito delas. Uma jatei ela gosta mais do ser humano, já se você ver as ei guaxu elas não gostam do ser humano, elas ficam mais bravas ainda se você mexe com elas, e não dá pra ter em casa, nem muito perto de casa por causa que elas vão em todas as coisas em todas as comidas e na roupa e no cabelo e sempre onde tem uma aparece outra e outra e depois fica cheio delas. Se você espantar elas, elas ficam furiosas e ai é que dão uma ferroada mesmo e depois vem outra e também vai ferroar, tem que fazer uma fumaça de mato para espantar essa abelha, ... ela é danada...."

Para a captura das abelhas ei guaxu existiam várias possibilidades. Em todas se corriam riscos, caso não fossem tomados alguns cuidados antecipadamente. Segundo Karai Poty, essas abelhas formam "cachos de muitas abelhas uma por cima da outra do lado de fora do próprio ninho, em árvores, em pedras e mesmo nas caixas". Para a sua captura no ambiente natural os índios ficavam esperando a época mais quente do ano, na qual, segundo ele, as abelhas sempre

“...saiam com quase toda família, mudando de lugar (enxameamento), nessa hora é que se colocava uma caixa perto. Quando a bola de abelha já estava bem grande punha uma caixa e ficávamos batendo na caixa. O barulho do oco da caixa é que atraía as ei guaxu e elas entravam. Às vezes ficavam e já 
começavam a trabalhar e a construir os favos, às vezes iam embora no outro dia".

A preparação das caixas para essa finalidade obedecia a uma metodologia diferente da aplicada para as abelhas sem ferrão. Para a captura de abelhas ei guaxu as caixas eram maiores, enquanto as caixas para as abelhas sem ferrão eram padronizadas, com cerca de 30,40 ou no máximo 50 $\mathrm{cm}$, variando pouco na largura, entre 15 e $20 \mathrm{~cm}$ e na altura, entre 10 e $20 \mathrm{~cm}$. As caixas destinadas às abelhas ei guaxu deveriam ter pelo menos o dobro do tamanho e de preferência não deveriam apresentar rachaduras ou emendas mal acabadas. Segundo o informante, qualquer pequena fresta poderia provocar saídas de abelhas atrapalhando a manipulação. No entanto, mesmo que a caixa fosse muito maior "(...) nem que a caixa tivesse um metro de tamanho, não era problema (...)", segundo Karai Poty.

As caixas para essa finalidade eram cuidadosamente preparadas, limpas e reforçadas para não estragarem em pouco tempo. Em seu interior era colocado algo doce. Podiam untar as caixas com um pouco de mel ou mesmo açúcar para que as abelhas se sentissem mais atraídas pelo cheiro, ocupando a caixa e iniciando ali uma nova colméia. De qualquer maneira a caixa era deixada por alguns dias no local, dois ou três dias,

“... depois num final de tarde, quase à noite, quando as abelhas já estavam todas dentro da caixa, tampamos a entrada e carregamos para o lugar onde ela iria ficar para sempre. Às vezes elas limpavam completamente a caixa e não ficavam, aí usávamos essa mesma caixa para outra abelha da mesma maneira, ou tirávamos as abelhas do tronco. Dava muito trabalho, tinha que ser com um pau com fogo, qualquer coisa que fizesse fumaça, bastante fumaça. Aí arrancávamos os favos com mel e colocava num balde e uma parte a gente colocava 
dentro da caixa com a rainha; sempre tem que ter a rainha. Inclusive se você prender a rainha logo que abrir o ninho e colocar na caixa, as abelhas todas vão para a caixa. Só umas poucas ficam no toco onde está o ninho, ai é bem mais fácil. Para mexer nessas abelhas eu demorei muito, meu pai não me levou muito criancinha não, quando se mexe com as ei guaxu é bom ser bem longe de crianças né? Muitas vezes nem precisava ir atrás dessas abelhas, elas apareciam em um galho perto da casa e tinha vez que entrava aquele monte de abelha de uma vez dentro da casa. Saía todo mundo correndo. Elas ficavam num canto paradinha, formando aquela bola. Sempre que elas apareciam sem ninguém mexer, sempre estavam mais calma e se a gente tivesse paciência a noite elas ficavam uma bola só, era bem mais fácil de por na caixa. Mas era muito perigoso, todo mundo tinha muito medo delas pegarem, não dá nem pra correr, é ferroada na certa".

O informante referiu-se às abelhas sem ferrão como sendo muito organizadas. Para explicar sua organização social e divisão de trabalho usou como exemplo a etnoespécie jatei, descrevendo-as como abelhas que possuem a rainha, com a família bem dividida sendo que algumas abelhas não saem de dentro da colméia. A divisão do trabalho dentro da colméia é estabelecida em grupos de abelhas com funções diferentes, algumas servem para auxiliar a rainha, ficando dispostas sempre perto desta. Explicou que outro grupo vai para o campo visitar as plantas e nunca voltam sem algum material para uso da família. Dentro da organização exposta pelo informante, esse é o grupo em que as abelhas trabalham mais, referindo-se ao esforço realizado e ao fato delas partirem diariamente para "fora da casa, voar muito, 
correndo muitos riscos e só depois de atingirem seu objetivo de irem nas flores e troncos de árvores voltam para casa".

Outro grupo de abelhas dentro de uma mesma família, fica de guarda na entrada da colméia. Ficam voando de maneira que olham tudo que está se aproximando e nunca deixam seus postos. Se o fazem são substituídas por outras abelhas que ocupam essa posição de maneira que a entrada está sempre sob a guarda. Explicou que se houver uma ameaça para a segurança da colméia, as abelhas que estão de guarda, mudam de posição, como se estivessem se preparando para um ataque a qualquer invasor e, se necessário, chamam outras que estão no lado de dentro da colméia. Em pouco tempo poderá ter um exército fora ou bem na entrada. Se o perigo acabar, as abelhas aos poucos se acomodam em seus antigos postos de trabalho e a colméia volta à calma inicial.

A divisão de trabalho entre as abelhas sem ferrão é reconhecida pela ciência. Segundo Sakagamy (1982), esses insetos apresentam um complexo sistema de organização social com castas bem definidas, o que lhes conferem diferentes funções e atribuições. As colônias são grandes com perenidade muito comum, observando-se a incapacidade das rainhas de fundar ninhos solitariamente.

O informante ainda explicou que após um dia de trabalho, o movimento fora da colméia diminui gradualmente, ao mesmo tempo em que a luz do dia também diminui. Com a chegada da noite as abelhas entram pelo túnel. Depois que todas entram, explicou que o túnel é fechado para que insetos estranhos não possam entrar. Do lado de dentro as abelhas ainda trabalham por alguns momentos e finalmente diminuem as atividades até que param quase por completo. Por outro lado, ao amanhecer, algumas rompem a entrada do túnel e o movimento novamente recomeça.

Durante os meses quentes do ano e naqueles em que existem mais flores, segundo o informante, as abelhas têm mais atividade, "... saem bem cedo para visitar as flores, saem muitas abelhas e dentro da colméia também o 
movimento é bem mais rápido..." Comparou a atividade da rainha na postura de ovos durante a temporada de calor com a época mais fria do ano, diferenciando e associando às condições ambientais e climáticas à extensão de postura da rainha, condicionando o comportamento individual e da colônia à oferta de comida e à qualidade do trabalho das abelhas campeiras:

“...a mãe não tem mesmo que botar mais ovinhos numa época em que a comida está acabando. Se a reserva dos ninhos não for suficiente para que todas as abelhas possam comer, ela bota menos ovos. No inverno ela não pode botar muitos ovos por que as abelhinhas que vão para as flores, trazem pouca comida. Às vezes as abelhas voltam das flores, mas aquilo que elas colheram não é usado da mesma forma, pode ser que ela pegou sujeira, não sei (...) quando os dias começam a ficar mais quentes então aos poucos as abelhas vão novamente começando a aumentar o trabalho. Dentro da casa se vê que elas andam mais pra cá e pra lá. Já é um sinal que logo vão ter várias abelhas nascendo e que a mãe voltará a botar muitos ovos. Em pouco tempo terá muitas abelhas novamente e muitas bolinhas cheias de mel. No frio elas passam quase o tempo todo paradas quase dormindo, andam pouco e fica tudo parado. Às vezes vi dentro do ninho que todas as abelhas estavam dormindo, quietas e eram poucas abelhas. Nessa época não se pode tirar de jeito nenhum o mel delas. Se você fizer isso, elas vão morrer..., só de mexer nelas já se corre risco de causar problema. Tem que se abrir o ninho para ver dentro dele, num lugar quente e tem que ser bem rápido. Se esfriar demais dentro da casa delas, elas morrem de frio." 
Segundo o informante, as abelhas não são todas pertencentes a um mesmo grupo de animais, isto é, existem diferentes tipos e espécies que compõe grupos distintos. Em sua concepção, as abelhas são "muito parecidas em algumas coisas e podem até mesmo confundir quem não conhece muito bem". Para explicar detalhes das diferenças que podem ser características importantes de suas particularidades dentro de determinado grupo ou individualmente, o informante classificou esses "insetos" ${ }^{44}$ em duas categorias distintas: a) abelhas sem ferrão e b) abelhas com ferrão. No entanto, explicou que uma outra categoria de "insetos" corresponde às kavy (vespas), que: “...também são parecidas com as abelhas, mas não são abelhas, não fazem mel igual às abelhas. Tem uma que faz mel em pasta. Todas são bravas e valentes e elas têm ferrão e picam sem dó, picam mesmo."

A categoria de abelhas sem ferrão apresentou o maior grupo de etnoespécies diferentes num total de treze ${ }^{45}$. Para algumas delas foram explicados minuciosos detalhes de sua ontogenia, biologia, ecologia, vida social, extração e uso de seus produtos, acondicionamento e transporte dos ninhos, enquanto para outras as explicações apresentaram menos detalhes, como será transcrito e discutido a seguir.

\footnotetext{
44 Deve-se levar em consideração que no domínio etnozoológico dos pesquisados a categoria "insetos" não aparece como padrão para essa classe lineana (classificação científica) e que nos procedimentos e relacionamentos entre os animais, os atributos êmicos transcendem à formulação da explicação. Na verdade tal maneira de explicar, só existe na condição oferecida pelo informante graças ao seu esforço em tentar esclarecer seu conhecimento e expor sua sabedoria, de forma técnica e teorizada. Valores desnecessários no convívio do seu dia-a-dia. Existe uma grande distinção entre seu conhecimento e a forma com que ele é transmitido em sua cultura em sua própria etnia. Nas explicações oferecidas para o pesquisador, conscientemente ou não, o pesquisado mesmo que não esteja respondendo a um questionamento semi-estruturado, procura adequar suas explicações da mesma maneira como o pesquisador procura adequar sua lógica conceitual às necessidades momentâneas. Ao se comunicarem, pesquisado e pesquisador, tentam concomitantemente eliminar a "estranheza" que os separa, um por que sabe que está partindo da oralidade do outro, no caso do pesquisador. E o pesquisado por que sabe que suas palavras poderão ser eternizadas quando grafadas pelo outro. Desta maneira, os dois tentam adequar suas manifestações aos objetivos específicos daquele momento, e os dois espontaneamente tentam encontrar um ponto comum para suas comunicações.

45 Litaiff (1999) refere-se a quinze espécies de abelhas entre os M'byá do litoral do Brasil, sendo que doze delas são abelhas sem ferrão, uma é a Apis Melifea e duas espécies de vespas. O autor agrupou todas as espécies na categoria "abelhas". Em seu trabalho não se discutiu o conhecimento das espécies em separado ou outros detalhes.
} 
A denominação usada para diferenciar cada etnoespécie em cada uma das categorias ${ }^{46}$, no idioma guarani em dialeto m'byá, foram também denominadas para o idioma português do Brasil, pelo próprio informante. No entanto, em alguns casos, tal denominação não era conhecia pelo informante que justificou tal fato com a seguinte interpretação:

\begin{abstract}
“(..) os juruá às vezes confundem as abelhas ou não dão nome a elas. Dizem que são abelhas e pronto (...) Têm mania de achar que tem que dar nome só pro bicho que ele vai usar pra alguma coisa. Vêm no mato e todo dia passa na porta da casa delas mas nem se preocupa em saber como é que ela é".
\end{abstract}

A seguir no Quadro 2, são apresentadas as etnoespécies de abelhas sem ferrão (A), abelhas com ferrão $(B)$ e vespas (C), mencionadas pelos informantes, na mesma ordem em que foram citadas durante a coleta de dados:

46 O sistema de classificação não foi suficientemente explorado por não ser o objeto deste estudo, portanto o sistema de classificação superior ou de super-ordenação não estão descritos de forma que configure a taxonomia definitiva na noção de ordenamento usada pelos Guarani. Porém, mesmo com os dados iniciais os agrupamentos indicados apontam seguramente para os padrões que foram expostos. 


\begin{tabular}{|c|c|c|c|}
\hline & $\begin{array}{c}\text { Abelhas } \\
\text { sem ferrão (A) }\end{array}$ & $\begin{array}{c}\text { Abelhas } \\
\text { com ferrão (B) }\end{array}$ & $\begin{array}{c}\text { Vespas } \\
\text { (C) }\end{array}$ \\
\hline 1. & jatei & mamanga & kavy typexaĩ \\
\hline 2. & ei pytã & mamanga guaxu & kavy taturã \\
\hline 3. & guarykua & mamanga pytã & aguarakavy \\
\hline 4. & ei raviju & mamanga uũ & kavy xi \\
\hline 5. & yvy ei & mamanga para & eixu guaxu \\
\hline 6. & ei tata & mamanga ĩ & \\
\hline 7. & ei mirĩ & ei guaxu & \\
\hline 8. & ei mirĩ ' $\mathrm{i}$ & & \\
\hline 9. & ei irapua & & \\
\hline 10. & ei ruxu ou akã moto & & \\
\hline 11. & madori & & \\
\hline 12. & ei tapexua & & \\
\hline 13. & kraxai & & \\
\hline
\end{tabular}

Quadro 2 - Etnoespécies de abelhas sem ferrão, abelhas com ferrão e vespas

5.2 (A) Abelhas sem ferrão (na ordem em que foram citadas pelo informante)

5.2.1 Etnoespécie: Jatei (idioma guarani, dialeto m’byá)

Descrição declarada pelo informante:

"são abelhas pequenas, do tamanho de um arroz, ou um pouco só maior, são bem pequenas. São amarelinhas, o corpo tem uma pequena curva, com o traseiro empinado para cima. A mãe, que os juruá (brancos, ou não-índios) chamam de rainha, é mais mole, anda mais devagarzinho, é maior e mais gorda e mais amarela e também tem aparência de delicada. Ela anda pela casa, se a gente perturbar 
ela, mas ela é calma. A jatei é uma abelha muito dócil, bem mansinha. Elas ficam voando perto da entrada. Sempre tem algumas abelhas no caninho que elas constroem. Sempre tem no corredor do caninho algumas abelhinhas que ficam por ali, às vezes elas entram e depois voltam. Tem outras que, elas ficam voando paradas no mesmo lugar, mas se você por qualquer coisa, até mesmo o dedo, perto, aí elas mudam de lugar, mas continuam voando ali mesmo. Às vezes, se você ficar mexendo alguma coisa na porta, parece que as abelhas que estão ali voando chamam as outras e saem mais algumas. Aí muda tudo, ficam algumas mais no caninho, aumentam as abelhas na porta e do lado de fora voando. Eu nuca ouvi dizer que elas atacaram, mas ela é valente e se você perturbar mesmo, elas ficam na porta tomando conta, uma voando aqui e ali em todas as posições, elas protegem a entrada. Essa abelha é muito limpinha, dentro do ninho delas, na casa, nunca tem sujeira. Elas cuidam bem do ninho, elas formam aquele caninho, um tubinho de cera para entrar e sair. Todo dia elas mexem na entrada, tem ocasião que elas estão fazendo mais um pedaço, aí elas diminuem um pedacinho, mas sempre tem um caninho pra entrar e sair. Pode chover muito que não chega a chover lá dentro. A colméia é formada por duas partes principais, tayrai, o favo né! É quase uma bola, é de cera muito bem formada sem defeito. É onde ficam as crias e tem a outra parte que é a embalagem, aí tem muitas bolinhas cheias de mel. As bolinhas vão sendo enchidas quando a jatei volta das flores. Umas bolinhas são cheias de evorakue (pólen). As duas 
partes são grudadas uma na outra. Existe também uma parte bem delicada, é como se fosse de folhas de papel, mas é de cera. É bem fina e muito delicada e molinha, uma folha fica em cima da outra, mas não é bem encima, é uma meio de lado da outra e meio em cima. Entre as folhas tem um espacinho separando e em alguns lugares elas são grudadas. Essa parte fica envolta do ninho, e como se tivesse ali protegendo o ninho, mas é tão delicado que se encostar nela pode amassar. É de cor mais para cor da terra, é como se fosse terra diferente da terra muito vermelha. É quase da cor da madeira mais escura. Mas às vezes tinha bem clarinha, mas não era branca era meio marrom clarinho. Tem uma tampa no tronco, uma embaixo que é onde as jatei colocam as bolinhas que vão encher de mel ou de pólen, uma parte delas fica presa ali, é em cima dessa tampa que o resto da casa toda vai ser construída e às vezes vem primeiro uma parte do ninho com as crias no meio das folhinhas. Tem outra tampa em cima de tudo. É a que fecha tudo. Então o interior da casa delas fica entre duas tampas bem forte, é a parte mais forte do ninho todo da colméia. Ela é que tampa e que segura tudo além de não deixar outros bichos entrarem. As vezes ela vai e monta a casa na pedra, ai é difícil de mexer, pra mexer tem que quebrar a pedra e sempre estraga tudo. Aí eu vi que as vezes ela faz o ninho de comprido na pedra. É por causa que fica mais apertado não tem como ela quebrar a pedra pra ficar largo então elas constroem tudo de baixo pra cima bem comprido. A jatei faz os ninhos em toda parte, as vezes num tronco de cerca, num 
pau qualquer, mas quando o ninho é muito pequeno ninguém nem mexia, a gente fica olhando e vê logo, se tem pouca abelha entrando e saindo e se o tronco é muito fino e pequeno a família é pequena e aí tem pouco mel, tem pouca cera e nem vale a pena mexer nessas. Elas preferem o oco das árvores, se é árvore velha elas preferem, deve ser por causa que a madeira é mais mole. A primeira coisa que elas fazem é encapar a madeira com um pouco de cera e uma outra coisa mais escura, uma massa, uma goma que as vezes estica e gruda. Depois que encapou tudo, está tudo limpinho e fica até com cheirinho próprio de abelha mesmo, elas constroem uma parte da tampa e depois é rapidinho para ir construindo tudo, fazem o caninho que vai dar perto dos favos com as crias. Cada abelhinha trás um pouco do material, às vezes elas saem de um ninho que está bom, um ninho bem forte e começam a construir outro. Mas não vão todas embora, é só uma parte. Aí vão virar duas colméias, duas famílias. Sempre que isso acontece fica uma zoeira na entrada do ninho delas, até que elas vão saindo e depois se acomodam em outro lugar. Por isso se você deixar uma caixinha vazia por perto se tiver bem limpinha ela pode entrar nessa caixinha, até pode por uns pedacinhos de cera e por a caixinha bem perto de frente mesmo pra que elas entrem, e se elas gostarem acabou o problema elas ficam sem problema, tem que prestar atenção para tirar dali e por em outra posição para não ficar uma de frente pra outra, não é bom, é uma provocação, mas pode por do lado uma da outra que não tem problema, pode por assim perto, não precisa ser 
grudado né? Mas pode por perto que não tem problema. A abelha é esperta ela não entra na casa errada de jeito nenhum, ela conhece bem a casa dela e não vai na outra. Se você for mexer e trocar de lugar enquanto elas estão trabalhando nas plantas estraga tudo fica uma bagunça e as abelhinhas às vezes brigam para tentar entrar e dentro da caixa fica um tormento. Então se precisa mexer tem que ser depois do sol. Aí no outro dia não tem problema, elas começam a trabalhar sem problema, você pode mexer bem cedo quando amanhece que também evita o problema. Quando é muito cedo elas sentem frio e não saem de casa, elas ficam quietas de medo do frio e aí também pode mexer. Mas se tá muito frio, quando você mexe o frio entra e pode dar problema. Tudo tem sua hora, não dá pra dizer a hora, tem que analisar naquele dia e aí tomar a decisão de mexer naquela hora ou não. Meu pai falava que quando tá uma zoeira na porta é por causa que pode ser que elas estão namorando. Não é pra mexer nessa hora de jeito nenhum, nem é bom ficar perto, fica um monte delas voando na porta. É bom deixar elas em paz nessa hora para não ter perigo delas irem embora. Nunca vi elas saírem e ficarem paradas em um galho ou em algum lugar no tempo. Elas sempre se instalam em algum lugar e às vezes saem do tronco e se instalam em outro tronco que é maior ainda. Quando ela vai para uma árvore maior é certeza que a família é forte, é bom sinal, é que logo ela ficará forte mesmo e a gente pode tirar e por na caixa e levar de volta para a área junto com outras caixas. Se o tronco for bom que dá para cortar ele fora sem 


\begin{abstract}
estragar, aí é só levar o tronco, mas tem que esperar, não pode ser no dia que elas mudaram de casa. Se esperar uns meses ai é certo que não tem problema".
\end{abstract}

Com base na descrição fornecida pelo informante sobre a etnoespécie jatei, a análise realizada pelo Dr. Paulo Nogueira-Neto ${ }^{47}$, aponta para a pista taxonômica referente a espécie Tetragonisca angustula.

O informante declarou que a abelha jatei recebe o nome de abelha "jataí" pelos brancos. A palavra jateĩ foi traduzida por Nogueira (1879) como sendo "nome de uma abelha e significa preguiçosa", Bueno (1987) faz a mesma referência sobre a palavra.

O informante manteve um meliponário de doze caixas em sua aldeia natal, Posto Indígena Rio das Cobras. Também mantinha sob sua vigilância várias colméias em estado natural, instaladas em ocos de árvores no limite da aldeia. Explicou que muitas vezes algumas abelhas se instalavam na própria parede de sua moradia: "normalmente essas eram pequenas, a família era muito fraca. Eu deixava lá mesmo, e não dava nem para tirar por causa que não tinha nada. Era bem fraca mesmo".

\title{
5.2.1.1 Utilização dos produtos
}

Praticamente todos os produtos das abelhas jatei são utilizados pelos Guarani. O mel e a cera são muito valorizados em sua cultura, outros produtos como o cerume, batume, pólen, própolis, as próprias crias em estado larval, também são utilizados em diferentes situações. Segundo os

47 O Prof. Dr. Paulo Nogueira-Neto, a quem devo agradecimentos especiais, analisou as descrições (pistas taxonômicas, informações declaradas pelos entrevistados), de cada uma das abelhas, e com as pistas (etno)taxonômicas oferecidas, concluiu a que espécie se referia e qual sua nomenclatura científica. Sobre os nomes populares no idioma português, existem possibilidades de a mesma abelha receber uma quantia muito grande de diferentes nomes, dependendo da região em que o inseto se localiza, esse é um dado que deve ser levado em conta segundo Nogueira-Neto (1997), devendo-se ter o cuidado de não se basear apenas no nome popular, segundo o autor, quanto mais dados se tem a respeito de um inseto o risco de erro sobre sua identificação é bem menor. O ideal e a captura de alguns espécimes para que um especialista possa identificá-lo com resultados confiáveis. 
informantes, o mel das abelhas jatei é apreciado como sendo saboroso, de paladar muito bom e muito limpo, sendo considerado um mel puro.

A utilização como alimento, revelou que o mel pode ser consumido diretamente dos potes $^{48}$, ou deles extraído. Sendo consumido puro sem qualquer adição, ou juntamente com os potes, mastigado-os para saborear seu conteúdo. Neste caso, os potes podem ser engolidos após a mastigação ou simplesmente cuspidos após bem mastigados, resultando em uma massa de cera e cerume mais escura. Não existe uma regra para essa ação, se o objetivo é o consumo do mel, fica a cargo do consumidor o descarte ou não da porção de cera e cerume resultante da ação. O mel também é usado como adoçante e complemento para adoçar alimentos e infusões, mas, foi substituído pelo melado de cana de açúcar e depois pelo açúcar refinado.

Sobre a regularidade do uso do mel em diversos manuseios do diaa-dia, foi declarado que sempre que se tinha o mel, dispensava-se o açúcar ou o melado de cana. O mel era armazenado em cabaças ou potes de cerâmica de fabricação própria dos Guarani. Também eram reusadas outras embalagens de vidro, ou mesmo, de plástico, embalagens bem fechadas. O mel era adicionado a quase todos os alimentos que necessitavam de paladar modificado para o mais doce. Apenas para exemplificar, podem ser citados o bolo de mandioca, banana, milho moído, entre outros alimentos sólidos e algumas infusões.

O uso na preparação de um produto alimentar que segundo o informante parece com o que os brancos chamam de bolo e que os Guarani chamam de tambojape, tem um formato variado, mas se aparenta a um pão pequeno, praticamente do tamanho de um "pãozinho tipo frances", foi explicado como sendo um alimento especificamente preparado para um ritual ${ }^{49}$ :

48 A denominação "potes", é comumente usada para se referir aos alvéolos ou células onde as abelhas armazenam o mel.

49 O termo ritual está sendo empregado no sentido de se referir a qualquer cerimônia de caráter religioso ou dos costumes da religiosidade ou simbólico que seguem preceitos estabelecidos para essa finalidade. 
“ ...é uma espécie de batismo, mas não é igual ao que é feito na igreja pelo cristão (...) é realizado a noite, em função de agradecer ao deus e a natureza entre outras coisas. Também se fala sobre as coisas do dia que se passaram e se agradece ao deus".

Os participantes desse rito preparam velas com cera de abelhas, que são levadas para a $o p y^{50}$ (casa de rezas), junto com a erva mate (ka'a) e o fumo de corda. O fumo (petỹ) deverá ser picado para ser usado nos cachimbos (petỹgua), durante a ação cerimonial. Esses cachimbos passam pelas mãos de várias pessoas, isto é, "pitam no mesmo cachimbo", inclusive jovens e adolescentes. A erva mate é depositada em uma cuia à frente de uma cruz estilizada, preparada com galhos de arvore seca e ali se penduram alguns colares de contas, sementes, dentes de animais e penas de algumas aves.

As mulheres preparam o tambojape, que é uma massa elaborada a partir de milho verde ralado e depois misturado com mel, ou preparado a partir do milho seco socado no pilão e misturado com água, sendo que também poderá receber uma quantia de leite. No entanto, sempre se adiciona o mel. Depois de bem misturados os ingredientes são levados ao fogo brando, devendo-se mexer sempre, misturando o conteúdo sem parar, para dar a consistência adequada.

O tambojape, depois de pronto, é exposto durante a cerimônia, mas não é consumido naquela ocasião. Ao término do ritual, quando os participantes saem para suas moradias, carregam uma pequena porção, e devem consumi-lo no outro dia pela manhã, antes de qualquer alimento, antes de iniciarem as atividades diárias ou mesmo de sair de suas moradias. Todos da família consomem uma pequena porção, mesmo aqueles que não estiveram

50 "Opy": a tradução para esta palavra adaptada para o português com grande influência do cristianismo pode ser: "casa de rezas" ou "casa para cerimônias, cultos, para atividades religiosas", trata-se de um local sagrado onde ocorrem além dos costumes de religiosidade, reuniões, comemorações diversas, "velórios", de qualquer maneira é um local considerado sagrado para os Guarani. 
presentes no ritual, no dia anterior. Segundo o informante, "isso faz com que as pessoas comecem o dia com a energia renovada, com uma energia nova".

O mel e outros produtos das abelhas, têm um destaque importante na elaboração de preparos da medicina tradicional, da terapêutica e em práticas profiláticas dos Guarani. A objetividade do informante foi esclarecer que determinados preparados nos quais os índios Guarani acreditam ser especificamente positivos no uso para a cura de algumas doenças ou males sintomáticos, pode ser um indicativo de que, até pouco tempo, essa manipulação estava presente no dia-a-dia da aldeia, sendo comum entre os seus habitantes.

As informações apresentadas evidenciavam características que implicam em uma subjetividade sugerindo que o informante fosse interpretado como um indivíduo que apenas repassa parte de seu conhecimento e do conhecimento coletivo, para a oralidade. Tais construções orais explicativas apresentavam-se com um intenso esforço didático do pesquisado em esclarecer, de forma muito simples, sua sabedoria e seu conhecimento pessoal e grupal, apontando para uma clara tentativa de elucidar ao pesquisador as práticas das quais ele tinha lembrança. Mas, em alguns momentos percebia-se que seu esforço se dava no sentido de buscar a continuidade de suas informações, como se fizesse parte de um colar, onde cada uma das contas que o compunha só se materializava à medida que uma outra conta pudesse ser encaixada no fio principal.

Na medida em que os diálogos iam se estabelecendo, notava-se que o informante montava um complicado "quebra-cabeças", onde sua preocupação não era apenas falar espontaneamente a respeito do assunto. A construção de suas explanações aplicava-se de forma que as frases eram cuidadosamente elaboradas. Havia uma demonstração clara em exprimir no idioma português aquilo que ele "pensava e sentia em Guarani".

Notava-se que ao mesmo tempo em que as explanações eram apresentadas, o informante rebuscava em sua memória "pedaços" repartidos 
de seu conhecimento, interligando-os para dar lógica aos dados. Tais fragmentos remontavam há muitos anos, desde quando era criança e vivia em sua aldeia natal no Paraná. Aos poucos, tais fragmentos se juntavam e compunham organizadamente a apresentação de uma parte de sua memória, de seu aprendizado e conhecimento.

De qualquer forma, surgiam em meio às citações e explicações do informante alguns momentos de silêncio introspectivo, em que seu olhar se perdia ao longe e sua feição se modificava como se ele mesmo não estivesse mais ali.

No entanto, os informantes dão alguns exemplos de uso de produtos das abelhas para os males que atacam o aparelho respiratório como os resfriados, tosse e gripes. Para o tratamento ou mesmo a profilaxia desses problemas, que atacam a saúde, é preparada uma infusão de flores do mamão que, segundo os índios Guarani, têm efeito para a melhora de quem apresenta tais males respiratórios. Afirmam que ao se adicionar mel das jatei, o produto terá efeito curativo, em vez de apenas servir para melhorar o estado sintomático.

Outros problemas como os do trato digestório, conforme as citações dos informantes: "queimação, azia e dores estomacais", podem ser solucionados a partir da mastigação de potes de mel, alvéolos com larvas de abelhas e potes com pólen. Segundo os informantes, ao mastigar vagarosamente e engolir esses produtos (cera, cerume, mel, larvas de abelhas, pólen, e bem provavelmente pequenas quantidades de própolis), as dores e sintomas anteriormente descritos desaparecem em instantes. Quando todos são ingeridos juntos (o pote com o mel e a cera ou os outros componentes como o pólen em seu pote ou ainda a parte do ninho que possui as crias nos alvéolos), "esses problemas desaparecem logo após mastigar e engolir, isso é de limpar o estômago ( $p y$ ‘a), sem causar qualquer outro problema”.

Algumas raízes, folhas e a cascas de certas árvores, são levadas à infusão; em outra etapa da preparação, depois de pronto, adiciona-se o mel de 
jatei. O resultado esperado é que produzirá um efeito para eliminação de todos os vermes. A crença a esse respeito está ligada a tomar o chá ainda quente. Pelas declarações do informante, "em certos casos os vermes saem ainda se mexendo, põem todos pra fora e limpa o intestino, deixando a pessoa sem os problemas que ela tinha antes de usar o remédio".

Outro preparado tem a função de acalmar as pessoas. Ao ingerir uma infusão de determinadas ervas com mel das jatei

$$
\begin{aligned}
& \text { “(..) a pessoa fica calma, se tiver nervosa passa } \\
& \text { muito rápido. As vezes, né, é preciso que se dê para } \\
& \text { a pessoa para poder conter aquele desequilíbrio, } \\
& \text { aquele nervosismo que passa para todo mundo, } \\
& \text { quando se dá para as crianças elas logo dormem". }
\end{aligned}
$$

O uso de ytxy, produto das abelhas que é explicado como sendo parecido com uma massa de cor escura, de consistência macia que estica, com a propriedade de grudar em qualquer coisa pode, segundo o informante Karai Poty, estar espalhada por vários locais no interior da colméia. É usado pelas abelhas para tampar algumas frestas ou ligar as partes diferentes do ninho na arquitetura interna da colméia. Pode ser encontrada em pequenas porções acumuladas, reservadas dentro da colméia. Esse produto é misturado com folhas ogue e torrado ao fogo. O resultante desse processo é usado para passar nas pernas e braços das crianças, nas articulações:

“...as crianças passam, elas mesmas, nas juntas das pernas e dos braços e por baixo do pé. Serve para evitar o kãgue raxy"(reumatismo). As meninas passam no rosto numa faixa de idade, (entre $10 \mathrm{e}$ 12 anos aproximadamente). Mas, não é uma pintura, é diferente de pintura é para proteger mesmo".

Quanto à cera das jatei, que é um produto muito cobiçado pelos índios, também tem diversas utilidades. Como foi visto anteriormente é ingerida 
em certas situações na condição de curativo para alguns males do trato digestório. No entanto, os informantes destacam a importância da cera (iraity), na fabricação da vela (tata endy) que é usada para iluminação, principalmente na casa de rezas. Essas velas eram fabricadas com um pequeno fio de algodão (qualquer barbante, em geral). Recebia gota a gota a cera derretida até formar uma vela propriamente dita. Normalmente quem fazia essas velas eram as mulheres mais velhas, atualmente o próprio informante tem fabricado essas velas para as ocasiões especiais, como ele explica: "algumas festas, como podemos dizer assim cultos, são preciso que se façam as velas com cera de abelha. Tem que ser cera pura e se tiver cera de jatei, é o ideal, por que a cera delas é bem purinha mesmo".

O uso da cera para polir peças de artesanato e penas de aves usadas em adornos sobre a cabeça, também é parte comum no universo desses índios. O informante explica que muitas vezes abriam as caixas ou as colméias trazidas em seus próprios troncos, apenas para a retirada da cera. Essa ação obedecia a muitos cuidados para não se correr o risco de estragar os ninhos, e para manter a arquitetura interna o mais preservada possível. Pela descrição oferecida, além da cera clara, partes do cerume eram extraídas nas mesmas condições, sendo que os dois produtos eram misturados e fundidos resultando em um único produto, principalmente quando se tratava de uso para o artesanato.

Com a chegada dos postos médicos próximos às aldeias, ou a visita de agentes de saúde na comunidade, ou mesmo o envio de índios para freqüentarem cursos de auxiliar de enfermagem e similares, houve uma diminuição gradativa do uso do conhecimento tradicional sobre o preparo de porções que eram usados entre os membros daquela comunidade.

Os mais jovens pouco fazem uso do conhecimento a respeito da fauna e flora para resolverem problemas de saúde. Usualmente visitam o "postinho", um posto de saúde dentro da própria aldeia. Procuram remédios 
para cura imediata de alguns de seus males. Isso favorece a distância entre eles e os costumes dos mais antigos.

5.2.2 Etnoespécie: Ei pytã (idioma guarani, dialeto m’byá)

Descrição declarada pelo informante:

"Essa é uma abelhinha ruiva, quase vermelha, ela é maior que as jatei, mas não é muito maior, ela é diferente em muitas coisas das jatei. A entrada do ninho delas é bem diferente, não tem aquele caninho, aquele biquinho que tem nas jatei. Mas é mais fácil de encontrar que as jatei porque elas ficam voando fora da colméia, e como são maiores são bem fáceis de serem vistas, da para ver de longe. É uma abelha calma, não se zanga fácil, mas se for perturbada ela ataca fica muito brava e se enrola nos cabelos, e ai não dá pra tirar ela mais do cabelo, ela fica enrolada, a gente tem que matar a bichinha para tirar dali. A entrada do ninho é um buraquinho que só dá para passar a abelha mesmo. Dentro da casa essas abelhas, no oco da árvore, elas sempre envernizam todas as paredes. É fácil de saber quando a abelha está no tronco a pouco tempo ou a muito tempo, o verniz que ela põe nas paredes, quando fica velho ela limpa e põe outro novamente, de modo que sempre está limpo e não entra umidade, nem quando chove forte. Ela sempre usa essa massa para fechar tudo dentro da casa, de modo que não entre nada de fora e não saia nada de dentro por qualquer buraquinho. Os favos têm uma parte que tem o pólen, sempre na mesma colméia existem mais que um tipo de pólen. Existem 
sempre uns mais doces que os outros, alguns são amargos mesmo, e tem alguns mais claros e outros mais escuros, acho que depende das plantas e da época que elas saem para visitar as plantas. Os ninhos com os favos de filhotes ficam formando fileirinhas, uma encima da outra, e é fácil de ver se tem algum que vai ser de rainha, é sempre maior e fica meio diferente dos outros que tem crias normais, que vão virar abelhas mesmo. A mãe de todas, ela é maior e também anda menos e a gente não vê elas voando para fora da casa, assim saindo pela mata. O ninho onde estão as crias fica sempre bem protegido, tem umas camadas de cera de folhas mais finas, que parecem que estão amassadas e grudadas umas nas outras. Se olhar de longe parece uma folha só bem amassada cobrindo todo o lugar onde estão os favos de crias. As bolinhas com o mel ficam separadas, elas são muito frágeis e se você encostar nelas, elas já podem quebrar.

Com base na descrição fornecida pelo informante sobre a etnoespécie ei pytã, a análise realizada pelo Dr. Paulo Nogueira-Neto, aponta para a pista taxonômica referente à espécie Tetragona clavipes.

O informante declarou que a etnoespécie ei pytã recebe esse nome principalmente por ser vermelha, ou quase vermelha. A palavra pytã pode ser traduzida para o idioma português como: vermelho ou marrom (Dooley, 1982).

Segundo Karai Poty, essa abelha é conhecida pelos brancos como vorá. Pesquisando o verbete em Ferreira (1986), verifica-se que "vorá" é uma variante de borá que em tupi (heborá) é a expressão: "o que há de ter (mel)". Bueno (1987), traduz a palavra borá como sendo "o âmago, o conteúdo, 
referindo-se ao favo de mel das colméias" sendo que vorá para esse autor é uma variante de borá e que significa "aquilo que está dentro de, isto é, o pólen das flores". Sampaio (1955), cita o nome dessa abelha referindo-se a uma abelha que pode ser encontrada em São Paulo e estados do Sul. Ferreira (op. cit.), se refere à palavra, como sendo a designação popular para uma abelha muito comum da Região Serrana do Rio Grande do Sul.

O informante nunca soube de alguém que tenha mantido essas abelhas em caixas ou em qualquer outra condição, considerou que "é mais complicado, ela sempre enrola no cabelo e dá trabalho, acho que não deve dar certo criar elas".

\subsubsection{Utilização dos produtos}

O mel da abelha ei pytã, também é considerado um mel de sabor muito suave, praticamente é usado "in natura" e misturado aos alimentos como no caso explicado anteriormente para as abelhas jatei. A retirada do mel implica sempre em destruição de grande parte da colméia. Sempre que essas abelhas são encontradas e se retira o mel ou a cera, na declaração do informante Karai Poty:

“... a casa delas é muito frágil, sempre estraga quase tudo quando a pessoa mexe para tirar o mel ou as crias com a cera, uma parte do mel já cai ali mesmo e nem dá pra aproveitar. Aquelas bolinhas onde ela guarda o mel são muito fininhas e sempre quebram todas, é bom levar uma bacia pequena para ir colocando os favos de mel dentro, por causa que eles se quebram todo quando a gente mexe. Também é bom deixar uma parte na árvore para que a família cresça novamente, mas é meio difícil, fica tudo muito estragado. Mesmo assim cheguei a ver algumas colméias que se refizeram, mas alguém foi por lá e retirou tudo deixou só um buraco e ai não 
voltaram mais, deve ter matado a mãe, ai é muito difícil fazer as abelhas começarem a família sem a mãe".

Segundo o informante preparo de um produto a base de raízes misturadas aos favos, com crias em estado larval (tayrai), da origem a uma solução que ingerida, acompanhando a orientação do pajé ou mesmo de outros índios mais velhos, tem o efeito, de estimular a fertilidade tanto masculina como feminina. O uso desse preparado da medicina tradicional dos Guarani foi considerado por ele como normal entre os índios em outros tempos, referindose a cerca de 20 anos atrás. Além de ser usado para o aumento da fertilidade esse preparado serve para interromper o efeito de outro, que tem como característica e finalidade evitar filhos e é resultante da manipulação de produtos de outra abelha, a guarykua, que será apresentada a seguir.

O mel das abelhas ei pytã pode ser guardado para uso posterior. Para tanto é retirado totalmente dos potes fabricados pelas abelhas e destinado a um recipiente bem fechado, não ser invadido por formigas. O mel separado da cera e cerume é passado na boca das crianças pequenas, de um ano aproximadamente. Esse costume, segundo o informante, é para a prevenção de certas feridas que possam surgir na boca das crianças. Neste caso, o mel das abelhas ei pytã parece estar sendo utilizado para uma função antibacteriana.

Estudos realizados por Cortopassi-Laurino \& Gelli (1991), verificaram que os méis de Meliponíneos que foram testados apresentaram ação antibacteriana considerada importante. No mesmo experimento compararam os resultados com mostras de méis de Apis mellifera que, segundo as autoras, apresentaram uma atividade antibacteriana bem menor. As autoras também explicam que o mel pode ser bactericida ou bacteriostático. Entre os méis testados no experimento estava o mel da abelha ei pytã. 
5.2.3 Etnoespécie: Guarykua (idioma guarani, dialeto m’byá)

Descrição declarada pelo informante

"Essa parece com a ei raviju mas, é bem diferente o jeito dela, e a cor dela é parecida só que é mais amarela e a barriga é bem preta e bem amarela, ela tem umas listras de preto e de amarela, parece que ela é amarela e tem as listas pretas envolta do corpo dela, ela é meio curta e gordinha e bem diferente da jatei que tem o corpinho bem fininho, se você olha ela assim por cima vê logo que tem perto da cabeça uma parte redondinha que é brilhante, é assim preta, depois vem as asinhas que ficam certinhas. Essa é uma abelha que é fácil de acostumar em caixa, sempre que você pega e coloca na caixa e deixa sem perturbar ela se acostuma e fica por lá mesmo, tem que deixar sem perturbar por dois ou três dias e ai ela fica e pode crescer rápido ou não. As vezes tem uma rainha e as vezes tem duas, eu já vi duas rainhas e elas não estavam brigando. A rainha é diferente das outras, na verdade ela é sempre diferente né, igual nas jatei a rainha é tratada diferente desde que nasce, até antes de nascer ela já é tratada diferente e pode ficar mais tempo que as outras, ela demora mais para morrer e sempre tem uma porção de abelhinhas cuidando dela, se uma sai parece que outra vem e cuida também. Ela é maior e meia ruiva, assim (...) brilhante. A guarykua também é mansa, não fica muito brava, se a gente pega a rainha com cuidado quando mexe na colméia, nos ninhos e põe ela logo na caixa e depois com muito 
cuidado põe a família, ou então deixa que elas vão sozinhas, mas tem que saber colocar os favos de filhotes e com muito cuidado para não amassar todos, ai logo elas começam a criar, sem problemas. A guarykua é muito fácil eu acho que tive mais de dez caixas e todas iam bem, ela é trabalhadora e se você deixar na sombra no lugar certo ela fica bem, sempre pegava elas na mata e quando punha na caixa e depois levava pra por no terreno perto da minha casa eu tomava muito cuidado, meu pai me ensinou que essa era uma abelha que não podia ficar na secura do tempo, então tem que colocar num lugar que não bate muito sol pra que ela não se incomode, se ela se incomoda ela vai minguando e depois acaba, ela é boa pra fazer a cera que era usada para fazer o chá pra que se tome para controlar a mulher e o homem também, pra se não quer ter filho mais ai dá para tomar esse chá e não pode comer carne vermelha, né, a mulher não pode comer a carne vermelha nem muita gordura né, ai toma e funciona mesmo, sempre funcionava mesmo. A guarykua é fácil de achar por causa que ela tem um ninho que parece um buraco que foi feito com massa de barro e cera, fica cheio de corte envolta do buraco de entrada e de saída também, é interessante por causa que ela vai sempre arrumando aquela entrada de forma que sempre tem uma ou outra abelha de vez em quando que fica ali arrumando. É como se tivesse escorrido um barro com cera e ficado grudado ali, elas entram e saem parece até que uma vai dar uma trombada na outra, mas nunca vi isso acontecer. O ninho delas é sempre perto do chão mesmo, bem perto, mas não é 
na terra que nem formiga, ficam o oco do pau e ali assim perto do chão. Elas fazem um barulho que é bem delas mesmo, um som quando elas voam e sempre tem alguma abelha voando por ali próximo da entrada, o zumbido é fácil de saber. As vezes ela dá bem perto do chão mesmo, ai é mais difícil de mexer pra tirar sem estragar muito. Ela gosta também de tronco caído e é interessante se você observar que quando ela faz a casa em tronco caído ela faz o ninho e as tampas e as bolinhas de guardar o mel um do lado do outro é diferente né, se o tronco está em pé ela constrói tudo encima da tampa de baixo, se o pau está no chão ela aproveita e usa as tampas de um lado e de outro e ai vai fazendo o meio cheio de bolinhas que é onde ela guarda o mel, que é de cera, é bem parecida com as bolinhas que as jatei fazem, só que é bem maior e tem mais mel. Pra proteção dos filhotes dela depois ela constrói uma bola e dentro tem o ninho delas que fica cheio de filhotes. Sempre está tampado e tem um filhote dentro e sempre elas vivem desmanchando e refazendo, ela tem essa mania de desmanchar e fica um buraco no lugarzinho e quando você olha novamente ela já tampou o buraco e preparou de novo para o ovinho e depois nasce outra abelhinha, é interessante que é tudo direitinho, uma bola que protege o ninho, quando elas começam a nascer acho que elas comem um pedaço do favinho onde elas tão, do tayrai, e ai elas a família toda trabalha de novo e faz de novo a casinha e depois coloca um pouco de comida e quando você menos espera está tudo fechado, ai tem uma larvinha lá. A cera dela é muito boa e tem 
uma cor um pouco diferente da jatei, parece que é mais escuro um pouco, e ela encapa as paredes também para ficar mais protegida né, mas é de um produto mais escuro e mais diferente que da jatei, ela vive mexendo e carrega as vezes de pouquinho em pouquinho a massa de cobrir o lado da casa, quando você fica muito tempo sem olhar e vai olhar ela tampou bem mesmo tem que forçar para abrir e depois ela cola tudo novamente".

Com base na descrição fornecida pelo informante sobre a etnoespécie guarykua, a análise realizada pelo Dr. Paulo Nogueira-Neto, aponta para a pista taxonômica referente a espécie Melipona bicolor.

O informante declarou que a etnoespécie guarykua recebe o nome de "guaraipo" pelos brancos. Considerou uma abelha muito boa para manter em caixas. Em seu meliponário manteve cerca de dez colméias em caixas e, alguns ninhos foram mantidos nos próprios troncos, no entorno de sua moradia, sob sua responsabilidade.

\subsubsection{Utilização dos produtos}

O mel é utilizado para a alimentação como no caso de outros méis, sobre esse produto houve poucos comentários. Entretanto o informante Karai Poty explicou que, nos potes abertos onde o mel é armazenado, é facilmente encontrado mel de boa qualidade, com bom aroma e gosto suave e que os potes são mastigados "para tirar bem o mel e depois cuspir, as vezes engole tudo (...)". Não ocorreram comentários a respeito da função curativa, preventiva às doenças e males, ou mesmo sobre a profilaxia com relação ao uso do mel dessa etnoespécie.

O batume, que o informante chama de tampa, destacou-se entre os produtos das abelhas guarykua no uso específico para um preparado da medicina tradicional dos Guarani. O batume, segundo Nogueira-Neto (1997), 
referindo-se aos Meliponíneos, é constituído de cerume, própolis e barro, podendo ainda segundo o autor ser composto de outros produtos. A infusão, preparada a partir do cozimento em água do batume, da colméia da abelha guarykua, tem função específica segundo o informante:

\begin{abstract}
"é um chá feito para controlar a mulher para que ela não tenha mais filhos, pode ser tomado pelo homem também, o ideal é que os dois tomem juntos para não ter filho. Como a guarykua é fácil de cuidar sempre é facinho ter a tampa para poder preparar o chá que tem efeito muito bom".
\end{abstract}

Esse "chá", do qual o uso se pode considerar como sendo um produto para controle da natalidade ou planejamento familiar, foi descrito como de uso normal pelas mulheres que não gostariam de ter mais filhos. $\mathrm{Na}$ explicação do informante, deveria ser seguido um "tratamento" que envolvia mais que simplesmente tomar o preparado.

Anteriormente à ingestão da infusão, durante alguns dias, as pessoas deveriam se preparar para que seu uso pudesse surtir o efeito desejado. O pajé, ou mesmo pessoas mais velhas, preparava o chá e indicava uma dieta específica para quem deveria usá-lo. Um diferencial que foi citado várias vezes pelo informante, refere-se à dieta das mulheres que, a rigor da explicação, obedecia a uma restrição tanto à carne vermelha e gorduras, como também apresentava a proibição quanto a alimentação com o mel das abelhas ei guaxu que, segundo o informante, "é um mel muito forte e não é costume que ele seja usado pela mulher que vai fazer esse tratamento para não ter filhos".

As explicações relacionadas ao não uso do mel das abelhas Apis mellifera (ei guaxu), sem dúvida mereciam uma justificativa mais pormenorizada. Entretanto, mesmo dirigindo o assunto especificamente para esse objetivo, tal fato não aconteceu, ficando o informante restrito apenas a declarar repetidamente que era costume de muito tempo na vida da aldeia e, 
não tinha certeza se podia ser por outro motivo, se não, o de que o mel dessas abelhas era muito forte.

O fato da não ingestão do mel das abelhas ei guaxu pelas mulheres, ser mencionado como uma restrição normal no dia-a-dia dos Guarani, no que concerne a alimentação ou mesmo ao uso desse produto, em preparos de porções para uso da medicina tradicional, pode ser considerado como um tabu.

O comportamento humano é regulado por uma série de normas e regras que, para cada etnia é vista com naturalidade e, praticamente não é considerada como uma proibição ou restrição. Tais normas, podem representar uma regulação para a disponibilidade de alguns recursos da natureza, onde se incluem os produtos das abelhas.

Os tabus representam as regras sociais que, segundo Colding \& Folke (1997), não precisam ser escritas para que funcionem e, sua aplicação determina um conjunto de atitudes e reações do indivíduo em face ao seu meio.

De fato, os tabus são restrições que, quando analisadas sob a orientação materialista, implicam em encontrar uma relação de custo/benefício para justifica-las. Tal análise procura explicações práticas para responder suas interrogativas. Segundo Harris (1980), essas ocorrências podem ser perfeitamente esclarecidas por meio desta abordagem. Uma outra forma de versar a respeito dos tabus, podendo parecer mais adequada para as metodologias usadas nas pesquisas etnobiológicas, é a de se referir ao caráter êmico. Segundo Sahlins (1979), as explicações para o entendimento das causas das restrições que estão contidas nos tabus, podem ser analisados do ponto de vista simbólico que, são baseados em fundamentos ideológicos.

A forma mais adequada de compreender como o tabu funciona, isto é, qual sua influência direta ou indireta sobre "o bem discutido", principalmente com relação ao exposto anteriormente sobre a restrição do uso do mel de abelhas ei guaxu, pelas mulheres da aldeia Guarani, deve compreender uma 
abordagem e englobar as duas proposições metodológicas apresentadas, possibilitando ao pesquisador uma visão onde haja a participação tanto materialista como emicista, uma vez que uma não exclui a outra e, na verdade se complementam.

Outros produtos, como a cera e o cerume que compõe a arquitetura da colméia, eram usados nos trabalhos artesanais com menos freqüência e, para a construção de velas. Na explicação do informante:

"a cor dela era muito diferente, era mais escura, mas tinha uma boa massa para se mexer e fazer as coisas (referindo-se às velas), não era tão clarinha como a cera das jatei, talvez fosse menos pura que aquela clarinha e quando ela derretia ela ficava as vezes ainda mais escurinha, mas servia para fazer as velas se a gente precisasse e no caso de não ter uma cera mais clarinha".

5.2.4 Etnoespécie: Ei raviju (idioma guarani, dialeto m’byá)

Descrição declarada pelo informante:

"É uma abelha maior que as jatei, é mais redonda parece ser mais gorda, assim mais redonda mesmo. Ela tem umas listas pretas e outras quase brancas na barriga, é bem esperta não fica uma porção delas na porta, se você olhar bem vai identificar assim na entrada da casa, bem na portinha, onde tem o furinho, você vê a cabeça de uma abelha, nem dá pra perceber direito, tem que olhar com bastante atenção, fica só a cabecinha dela escondida ali, quando vem uma abelha então sai a que está na entrada para que a que chegou entrar, elas saem e entram pela mesma porta e sempre tem 
aquela que fica ali de guarda, olhando pra fora, eu acho. Fica difícil de encontrar na mata por causa que você não vê aquelas abelhas voando na porta e aí tem que ficar muito concentrado para conseguir encontrar. É lógico que você acaba achando elas por causa que elas gostam de pau velho, faz a casa em tronco que está morto e as vezes já está no chão. Essa abelha vai longe de casa e as vezes se você tentar seguir ela não consegue, elas voam bem longe é mais fácil ir olhando tudo e as vezes dá para ouvir o zumbido delas voando, se você ficar com bastante atenção vai acabar encontrando. O ninho delas é diferente das jatei fica tudo dentro de uma bola que é bem feita, protege bem a família. A entrada da casa delas, do ninho, a entrada é bem diferente das jatei, é uma entrada de barro seco que elas fazem e só uma abelha entra de cada vez. Se você quer tirar essa abelhinha de uma árvore tem que preparar para tirar a família toda de uma vez, se você tirar aquela bola onde elas estão e colocar numa caixa, elas vão começar a criar uma condição ali para ficar e sempre escolhem começar do chão da caixa para cima. Se pegar a rainha e não estragar aquela parte que tem o ninho com os filhotes, ela fica na caixa e não tem mais problema. Elas preferem as árvores bem deterioradas $e$ costumam forrar o tronco com uma massa bem dura e seca, em qualquer lugar que tenha uma entrada elas fazem uma parede bem forte dessa massa que não é cera, é mais dura, deve ter um pouco de cera no meio dessa massa, mas não é de cera e tem uma aparência mais rústica, como se a mistura da massa não fosse por igual. É bem diferente da tampa que 
tem na casa das abelhas guarikua, com as ei raviju não se usa para fazer nenhum remédio nem nada de beber, parece que é meio sujo. Elas usam um barro mais sujo e não misturam direito, fica uma coisa assim sem misturar direito".

Com base na descrição fornecida pelo informante sobre a etnoespécie ei raviju a análise realizada pelo Dr. Paulo Nogueira-Neto, aponta para a pista taxonômica referente à espécie Melipona quadrifasciata.

O informante declarou que a etnoespécie ei raviju é conhecida pelos brancos como "mandaçaia". Manteve oito colméias em caixas, algumas delas cedidas por seu pai, enquanto outras foram fabricadas por ele mesmo. Declarou que manteve três troncos com a colméia em estado natural no espaço da aldeia e, neste caso, não foram necessárias transferências para as caixas, pois eram ninhos que estavam bem instalados e permitiam que se extraísse o mel em boa quantidade.

\subsubsection{Utilização dos produtos}

Embora o informante tenha declarado que o mel da abelha ei raviju seja consumido em estado natural, não deu muita importância para o consumo desse produto, dessas abelhas. Em momento algum relacionou qualquer preparado que se poderia ter, a partir dos produtos da abelha ei raviju na medicina tradicional entre os Guarani.

Verifica-se que o tratamento dado à questão da aparência do interior da colméia, com relação ao uso do batume, pelas abelhas ei raviju, na explicação de que a abelha "não é tão limpa", foi uma preocupação que o informante manteve, detalhando os pormenores da mistura existente entre o cerume, as resinas e o barro. O informante levou em consideração uma desproporção entre os componentes, desqualificando esse produto para o a utilização em seus costumes da medicina tradicional, tanto em usos curativos 
ou profiláticos, como foi o caso de produtos similares extraídos de outras etnoespécies de abelhas.

Comparando esses dados com os que se verifica na literatura, podese encontrar observações a respeito de pesquisas realizadas no batume das abelhas Melipona quadrifasciata (Nogueira-Neto, 1997), onde foram detectados excrementos de animais vertebrados na composição de várias amostras do produto. Tais análises realizadas nos laboratórios da CETESB ${ }^{51}$, em 1993, revelaram a presença de coliformes fecais. Em mais da metade das amostras, foi constatada a contaminação por Escherichia coli. No mesmo trabalho, o autor cita que essas abelhas usam barro com própolis para a arquitetura dos batumes, “(...) no ninho dessas espécies ambos materiais estão algo separados ou grosseiramente misturados (...)", em alguns casos se pode detectar montículos de fezes separadas pela colméia, que as abelhas colocam em alguns locais, Nogueira-Neto (op. cit.), supõe que esse comportamento possa ser para a marcação de território.

De qualquer forma, a explicação bastante resumida do informante Karai Poty, a respeito do não uso dos produtos das ei raviju, para preparação e uso na medicina tradicional dos Guarani, encontra apoio na literatura científica, assim como sua explicação, de que a massa que recobre o interior da colméia é de aparência suja.

A cera das abelhas ei raviju é usada no artesanato, para engomar peças e, para o fabrico de velas que são utilizadas na casa de reza (opy), durante os rituais e festejos.

51 Companhia de Tecnologia de Saneamento Ambiental, subordinada à Secretaria de Estado do Meio Ambiente (SEMA), do Governo do Estado de São Paulo. 
5.2.5 Etnoespécie: Yvy ei (idioma guarani, dialeto m’byá)

Descrição declarada pelo informante:

"Essa é uma abelhinha bem pretinha, é inteira preta, ela é pequena é diferente, faz o ninho debaixo da terra, parece formiga, pode até ter gente que pensa que é formiga, ela é daquelas abelhas que você tem muita dificuldade de encontrar por causa que ela além de ser pequena e ser de fazer ninho debaixo da terra, ela não fica voando envolta da entrada, então você tem um trabalho muito grande se pretende encontrar essa abelhinha. A entrada é um buraquinho bem pequeno e as abelhas não saem de monte de uma vez, sai uma e depois sai outra, vem uma e outra vem depois e tem um espaço de tempo entre uma abelha e outra, isso deixa ela escondida. As vezes o ninho tem mais de meio metro de profundidade, tem que escavar com bastante atenção, vai seguindo o caminho delas e fazendo um buraco grande envolta que é pra poder pegar onde ta a casa delas. As vezes não é tão fundo e se usava falar ka'i akã pekue" para dizer que não está tão fundo, que está ali bem próximo. (A tradução para essa expressão poderia ser, segundo o informante Karai Poty, "a cabeça do macaco" ou "o osso fino da cabeça do macaco". Segundo o informante essa expressão é falada quando se encontra a entrada do ninho, “...em vez de falar encontrei o ninho da yvy ei a gente fala bem rápido ka'i akã pekue, quem ta por perto já sabe que o ninho está bem ali". Para tirar o mel tem que se tomar muito cuidado para não estragar tudo 
misturando com a terra. O ideal é escavar envolta da casa toda e tirar tudo, o formato é mesmo como se fosse a cabeça do macaco, aquele ossinho fininho, envolta tem uma proteção e dentro está cheio de bolinhas de mel, são os favos que ficam sempre cheios de mel, e alguns tem os filhotes, mas na hora é difícil de separar por causa que as bolinhas são pequenas e muito juntas e quase sempre estraga uma parte por causa que mistura com a terra. Muitas vezes a gente acaba comendo o mel no lugar que encontrou por causa que é muito pouco e nem dá para levar pra lugar nenhum".

Com base na descrição fornecida pelo informante sobre a etnoespécie yvy ei a análise realizada pelo Dr. Paulo Nogueira-Neto, aponta para a pista taxonômica referente à espécie Paratrigona $s p$.

O nome yvy ei, segundo o informante, significa "abelha da terra" ou "abelha do chão", porém ele não sabe qual o nome que essa abelha recebe no idioma português. Não conheceu qualquer pessoa que tenha mantido essas abelhas em caixas, ou que tenha mantido vigilância sob ninhos, que ficam abaixo da terra.

\subsubsection{Utilização dos produtos}

Os comentários do informante sobre os produtos das abelhas yvy ei foram claros quanto à qualidade, apenas o mel foi citado como produto de uso entre os índios. O mel foi considerado bom, porém muito fraco e sempre encontrado em pequena quantidade. Não é um mel tão saboroso quanto o mel das jatei, conforme declaração do informante Karai Poty: "a cera não presta pra nada e o mel a gente usa pra comer ali mesmo".

Embora não tenha declarado que as crias e as larvas também servem como alimento, ao serem analisadas suas declarações, verifica-se que 
as larvas devem ser consumidas junto com os favos de mel e, provavelmente parte da cera que os constitui é consumida nas mesmas condições.

5.2.6 Etnoespécie: Ei tata (idioma guarani, dialeto m’byá)

Descrição declarada pelo informante

"Essa abelha é bem pequena, é pretinha e parece com uma outra a ei mirĩ e parece também com a jatei, só que é menor que a jatei. Ela é de costume de fazer o ninho na madeira, em tronco já velho. Por dentro do ninho é bem parecido com o ninho de jatei. Eu abri o ninho delas só por curiosidade, queria ver como era, por que ela é diferente, ela não pica, mas por onde ela passa na pele, um tempo depois fica como se fosse queimado, fica o caminho certo de onde ela passou. Ela fica muito brava se você mexe no ninho, vem encima mesmo. Dentro do ninho até parece que é tudo igual a outras abelhas, só que o mel não pode ser usado não, eu nunca ouvi dizer que alguém usou. Acho que ninguém nunca quis ter uma abelha dessa, ela é perigosa, ela queima mesmo, e sempre que mexi nessas abelhas tinha que tomar uma queimada delas, largava ela pra lá. Aproveitava um pouco da cera, se você usar a cera ainda vai, em último caso se não tem outra, ela serve para fazer umas velas, mas é difícil, não é tão comum usar essa cera, se tem outra ninguém vai usar justamente essa que dá muito trabalho para pegar sem ter certeza que não vai ficar queimado em algum lugar". 
Com base na descrição fornecida pelo informante sobre a etnoespécie ei tata a análise realizada pelo Dr. Paulo Nogueira-Neto, aponta para a pista taxonômica referente à espécie Oxytrigona tataira.

O informante explicou que, embora não conheça qual o nome que os brancos costumam dar para essa abelha, a tradução para o português é "abelha de fogo". Segundo ele, dificilmente alguém gostaria de manter essa abelha em caixas, além de não ter utilidade para o mel que, não é comestível e, própria abelha é perigosa de mais para que se arriscasse manter caixas apenas para tirar um pouco de cera.

\subsubsection{Utilização dos produtos}

Conforme as declarações do informante, o único produto das abelhas ei tata que era usado, era a cera e provavelmente o cerume que se misturam na arquitetura da colméia dessas abelhas. Uma vez retirada a quantia de cera e, provavelmente, cerume, sem o zelo cuidadoso para que não acontecessem estragos e perda da colméia ou as abelhas, o produto era levado para a aldeia e, o tronco onde havia sido encontrada a abelha era deixado ali mesmo, abandonado e semi destruído. O informante explicou o procedimento: "o tronco era aberto e se tirava a parte de cera mais limpa e sem ter perigo de estar pegando favo com abelha, ai a gente largava o resto por lá, acho que as formigas comiam o que sobrava".

5.2.7 Etnoespécie: EI mirĩ (idioma guarani, dialeto m’byá)

Descrição declarada pelo informante

"Essa é menor que a jatei, é bem pequininha mesmo, é bem pretinha e a casa, a colméia, não é muito grande, a família toda não é muito grande são poucas abelhinhas. Elas acabam fazendo o ninho em qualquer lugar, num bambu ou numa madeira velha, num cantinho qualquer elas se viram e se 
metem lá e fazem a casa delas sem problema, as vezes no tronco da árvore que tem outra abelha pode ter essa, não é no mesmo ninho, mas é no mesmo tronco, mas isso também acontece com as jatei. As vezes tem uma abelha que ocupa um oco de tronco velho e no mesmo tronco tem outra abelha, a ei mirĩ podem fazer isso por que elas não ocupam um buraco grande de mais, então ficam em um lugar assim meio pequeno, né. As vezes você via elas na parede da nossa casa, num buraquinho que não podia ser grande né, e ela ia lá e montava um ninho. Dentro do ninho sempre é muito pequenas as bolinhas de mel, os favos são grudadinhos, todos são bem presinhos uns nos outros e é sem proteção, se você abrir o bambu, vai já estar abrindo a colméia no meio e é certeza que vai estragar tudo, tem que usar o mel muitas vezes na hora, mas dá pra levar com um pedaço da própria madeira ou aquela meia parte de um bambu. Se raspar o bambu saem todos os favinhos, de mel e de cria, eles são de uma cera bem fininha. Tem uma massa bem grudenta e mais escura que parece com a que se encontra no nino das jatei, as vezes tem um pouquinho dessa massa que acho que é ytxy mesmo (própolis) que está grudado em várias partes. Nós sempre sabíamos que se mexesse ali, não ia ter jeito vai destruir tudo, da muita dó as vezes que você tira o mel e depois tem certeza que não sobra nada delas pra recomeçar, ai sabendo disso a gente já leva tudo mesmo, é uma destruição, mas ela tem bastante na mata, as vezes via e nem mexia, não é sempre que a gente destrói o ninho e as abelhas, mas se precisar destruir para tirar 0 
mel, ai não tem jeito, não dá as vezes pra ter opção. A ei mirĩ é mansinha e calma, ela nem que fica brava também não adianta, ela sempre sai perdendo por causa do tamanho dela que é pequeno de mais, elas ficam ali voando, algumas ficam na porta voando, na entradinha tem uma cerinha molinha e branquinha, as vezes é mais escurinha um pouco mas quase sempre é bem branquinha e por dentro já é mais escurinha, mais castanha, o mel é bem suave, bem do tipo suave mesmo, é um mel que é usado mais para a criança quando ela nasce.

Com base na descrição fornecida pelo informante sobre a etnoespécie ei mirĩ a análise realizada pelo Dr. Paulo Nogueira-Neto, aponta para a pista taxonômica referente à espécie Plebeia spp.

O informante declarou que a etnoespécie ei mirĩ recebe a denominação de "mirim" pelos brancos. A tradução de mirĩ, para o idioma português é "pequeno ou pequena". Ele desconhece qualquer pessoa que tenha tentado manter essa abelha em caixas ou mesmo tenha tentado manter um ninho em estado natural, explicando que é um ninho muito diferente, pois abriga um número pequeno de espécimes. Por ser muito delicado, seria difícil mantê-lo apenas para tirar o mel.

\subsubsection{Utilização dos produtos}

O mel das abelhas ei mirĩ é consumido como alimento no próprio local de extração, é ingerido juntamente com parte dos potes de cera que o armazena e provavelmente, embora o informante não tenha dito, boa parte das crias são consumidos na mesma situação. Além de ser usado como alimento, Karai Poty declarou que:

“...sempre procurei não matar as ei mirĩ por que elas não fazem mal a ninguém, são muito pequenas e na 
aldeia onde eu fui criado se procurava essa abelha para pegar o mel que era para se passar na boca de criancinhas que acabavam de nascer. Se você passa esse mel antes de qualquer coisa quando a criança nasce, passa na boca, no lábio da criança, protege e não dá nenhuma infecção, nem vai dar feridas depois. Era costume de fazer isso antes da criança comer qualquer coisa, logo que nascia se fazia isso. Era uma garantia contra as feridas que as crianças pegam na boca, esse mel protege contra isso. Então sempre tinha um pouco dele guardado e se não tinha a gente tinha que arranjar".

O uso do mel em condição natural, como produto preventivo e profilático aplicado aos lábios de crianças recém nascidas, foi considerado um dado interessante, porém muito preocupante pelo Prof. Dr. Paulo NogueiraNeto. Ele afirmou que é muito perigoso o fato de se usar o mel nas crianças antes delas completarem um ano de idade, devido ao mel poder estar contaminado com alguns microorganismos patogênicos como a Salmonella $s p$ ou a Escherichia coli, entre outros. Embora os méis de Meliponineos apresentem um pH baixo, capaz de impedir o crescimento desses microorganismos, as pesquisas realizadas mostraram que as contaminações ocorrem "na média das amostras". Além do mais, o sistema imunológico do ser humano até o primeiro ano de idade tem dificuldade em se defender da infecção desses mesmos microorganismos ${ }^{52}$.

Confrontar os dados do informante com os dados científicos a partir de um depoimento pessoal de fatos que ocorreram a no mínimo 15 anos atrás, pode neste caso, incorrer em falhas metodológicas por se tratar do envolvimento de dados hipotéticos sobre as condições fito-sanitárias a que se submetiam, tanto os indígenas como o mel das abelhas em discussão. De fato pode-se afirmar que as condições a que estão submetidas as populações das

52 Paulo Nogueira-Neto, comunicação pessoal, (2002). 
aldeias indígenas, próximas às cidades, não são condizentes com as qualificações de asseio pretendidas pela sociedade científica, porém o índio Karai Poty não está falando dos costumes atuais.

Hoje, como já foi descrito anteriormente, os índios freqüentam médicos e seus descendentes nascem em maternidades, assistidas por equipes médicas, com enfermeiros e auxiliares; muitas mulheres indígenas têm seus filhos por parto cesariano e na aldeia onde reside a família do informante, praticamente a totalidade das mulheres grávidas realiza pré-natal regularmente.

Quando foi solicitado ao informante que falasse mais sobre o costume de uso do mel nas crianças recém nascidas, tentando-se ampliar os dados sobre o assunto, ele apenas repetiu, com outras palavras, as mesmas informações sem, em nenhum momento, citar qualquer problema que a aplicação do mel poderia causar às crianças submetidas a tal condição. Afirmou que na aldeia era uma necessidade a profilaxia a partir do método que os mais antigos já ensinavam às meninas para que elas, quando crescessem e tivessem seus filhos, não corressem o risco de não aplicar o mel nas crianças. Na sua concepção:

\footnotetext{
“...não haviam remédios e nem médicos, as condições eram bem diferentes das que temos hoje, se não fizéssemos aquilo pra proteger as crianças, elas podiam ficar com a boca cheia de feridas e poderia ser mais sério e mais grave, a gente tinha que se prevenir".
}

Outros produtos dessas abelhas como a cera ou o cerume que foram citados durante a descrição da etnoespécie pelo informante, não aparecem em suas explicações como produtos de qualquer utilidade. 
5.2.8 Etnoespécie: Ei mirĩ ‘i (idioma guarani, dialeto m’byá)

Descrição declarada pelo informante

\begin{abstract}
"A abelha ei mirĩ 'i é muito pequena, é menor ainda que ai ei mirĩ, é bem parecida com a ela só que menorzinha. Usa bambu, e tronco velho e as vezes até mesmo no cipó tem abelhas que fazem a colméia, qualquer buraquinho, qualquer coisa que elas encontram que da pra elas montarem o ninho já serve. Muitas ficam na parede da casa que a gente está morando, mas como pode ter mel ali se é tão pequeno, ai a gente nem tenta mexer, e as vezes ela fica por bastante tempo fazendo o ninho e um belo dia desaparecem. Ela também tem na casa sempre uma cobertura na parede para tampar todos os buracos, fica bem fechado e elas deixam essa massa as vezes guardada em num lugar, deve ser para uma emergência, fica um montinho dela num lugar da colméia, é grudenta e estica e gruda em qualquer lugar. Eu vi disso nas jatei nas ei mirĩ ' $i$ e em outras também, acho que todas elas usam para tampar a casa da água da chuva e do frio. A entrada da colméia é bem pequenininha e algumas vezes as abelhas ficam pra fora uma porção delas, mas depois entram novamente. Se quiser mexer para tirar o mel, é igual à ei mirĩ não sobra nada mesmo, é muito pequeno e se mexer ai destrói tudo, por isso é que tem que ter certeza se quer mexer nessa abelhinha".
\end{abstract}


Com base na descrição fornecida pelo informante sobre a etnoespécie ei mirĩ 'i a análise realizada pelo Dr. Paulo Nogueira-Neto, aponta para a pista taxonômica referente à espécie Friesella schottky.

O informante declarou que a etnoespécie ei mirĩ ' $i$ é denominada de "mirinzinha" pelos brancos, e que a tradução para o idioma português de ei mirĩ ' $i$ é "pequenininha”. Também, para esta etnoespécie, desconhece qualquer pessoa que tenha tentado manter as abelhas em caixas ou tentado manter os ninhos encontrados em seu estado natural para a retirada de mel ou cera. A justificativa é praticamente a mesma que para o caso das abelhas da etnoespécie ei mirĩ.

\subsubsection{Utilização dos produtos}

Os produtos dessa abelhas como o mel e a cera, ou os potes com pólen e crias são consumidos diretamente no local da extração como é o caso da ei mirĩ 'i. O mel tem o mesmo destino, isto é, ser usado para que se passe nos lábios das crianças recém nascidas, com o mesmo propósito de prevenir o aparecimento de feridas.

Perguntado a respeito do armazenamento do mel, o informante explicou que o ninho retirado de seu local de origem era colocado em um prato desses usados para a alimentação, para que o mel pudesse escorrer por gravidade. A concentração da parte mais limpa desse produto podia ser armazenada em recipiente pequeno, limpo e que oferecesse a possibilidade de ser tampado de maneira a não permitir a entrada de insetos ou a contaminação por qualquer coisa. Para essa ação eram re-usados pequenos frascos: "uns vidrinhos que nem sei como é que chegaram até a gente". O informante explicou que na verdade não se guardava aquele mel por muito tempo; após o uso medicinal em uma criança o frasco podia ser passado para outra mulher que deveria fazer o mesmo, mas acabava sendo consumido ali mesmo, pois a quantia que se conseguia obter da extração do mel dessas abelhas era muito pequena para que se mantivesse qualquer estoque. 
5.2.9 Etnoespécie: Ei irapua (idioma guarani, dialeto m’byá)

Descrição declarada pelo informante

“É redondinha, essa é a abelha que até é parecida com a ei tapexua, só que é diferente é um pouco mais arredondada. A gente fala ijapu'a que quer dizer que é redondo, se você passar para o português. Então você sabe né que o mel a gente chama no guarani de ei. Então você vai vendo que o nome dela é por causa que ela é arredondada e faz mel então ficou assim, e a gente fala dela se quiser como sendo a ei ijapu'a, é só uma curiosidade que eu estou falando pra você saber. O formato é redondinho e essa é uma abelha diferente, ela não tem ferrão mas ela causa problema por causa que ela vem no cabelo e enrola no cabelo e depois ela corta o cabelo, ela morde e corta e ela é brava, morde mesmo. O ninho delas também é diferente, é uma bola grande do lado de fora da árvore. É uma bola grande que elas fazem nos galhos de uma árvore e é formado por uma capa que não molha de jeito nenhum, pode chover muitos dias que não tem como molhar o lado de dentro. Por cima, na parte bem encima do ninho tem uma cobertura que é bem dura mesmo, parece um osso de tão dura e depois em baixo dessa parte vem uma parte que é mais mole, mas é forte, não é fácil de cortar, é bem forte. Quando se tira o mel é ai que a gente tem que cortar para pegar as bolinhas de mel ou de pozinho esse que você chama de pólen, os potes desse pozinho as vezes estão em grande quantidade, em qualquer ninho tem, de qualquer tipo de abelha, 
sempre tem, e na ei irapua as vezes tem bastante. Dentro da colméia, assim do ninho delas, dentro da casa mesmo, a gente percebe que é tudo separadinho, tem uma parte que tem o mel e não tem os filhotes nem mesmo as bolinhas cheias de massinha de pólen, esse pó que as vezes é de cor diferente, tem amarelinho $\mathrm{e}$ as vezes tem meio vermelhinho, tem mais claro e mais escuro e até mesmo já vi alguns que tinham de várias cores em um só ninho né, as vezes o gosto é diferente de um pro outro, e as vezes tem alguns que são escuros e são muito mais sem doce, sem gosto, assim sem aquele gosto mais doce. O ninho pelo lado de fora tem uma capa que é como se fosse formada de pauzinhos cortadinhos e um pouco de tudo ... tem assim uma ou outra sujeirinha que as abelhas põe lá e depois grudam tudo com um pouco de barro e fica impecável, tem as vezes que elas usam mato, palha de mato seco e se você olhar bem tem até abelha morta misturada no meio, é uma casca bem grossa que protege bem o ninho delas. O lado de dentro está sempre igual, se chove ou não elas continuam com aquele jeito e mesmo se está um sol muito quente elas continuam daquele jeito, e sempre tem muitas abelhas. Quando você decide que vai mexer já sabe que vai tomar mordida delas, e as vezes dá trabalho mesmo, quando você começa a mexer fica um monte delas te perturbando. Quando você separa o mel delas e os favos de tudo mais, a goma que elas fazem que é bem grudenta, ai acabou o ninho delas, se mexer nelas é difícil sobrar alguma coisa, tem gente que vai mexer com um pau de com fogo né, faz assim um tipo de tocha e depois queima 
uma parte e depois tira o resto. Eu preferia não fazer isso que além de estragar muito mais o mel também não fica muito bom, pega gosto. O mel é usado as vezes para comer na hora mesmo, depende muito quem está tirando, você pode levar para comer depois e até guardar e as vezes tem mel que é mais escuro e tem mel que tem um gosto mais amargo que é por causa que a abelha vai em alguma planta que deve ter esse gosto, se for em pé de fumo estraga o mel, fica muito amargo e ruim e ninguém gosta. Com a goma que parece aquela que tem nas jatei o ytxy, só que é mais escura, ela é grudenta também, as vezes é mais grudenta que a que tem nas jatei, a gente prepara uma mistura dela com uma folha igual a que se faz com a jatei e serve bem para passar nas juntas também".

Com base na descrição fornecida pelo informante sobre a etnoespécie ei irapua a análise realizada pelo Dr. Paulo Nogueira-Neto, aponta para a pista taxonômica referente à espécie Trigona spinipes.

O informante declarou que a etnoespécie ei irapua recebe a denominação de "irapuã" ou "arapuá" pelos brancos. Neste caso, também desconhece qualquer pessoa que tenha tentado manter essas abelhas em caixas, ou mesmo levado o ninho em estado natural para realizar a retirada de seus produtos por perto da moradia indígena.

\subsubsection{Utilização dos produtos}

O mel é usado como alimento podendo ser ingerido diretamente dos potes ou com os próprios potes, quando estes são mastigados, ou no caso de ser separado, os favos de mel são esmagados com as próprias mãos, atividade que poderia ser realizada pelos homens, mas normalmente, é realizada pelas mulheres. Os favos esmagados são deixados para escorrer num prato ou 
pequena bacia e depois separado dos resíduos de cera e cerume. A massa resultante da separação entre o mel e os resíduos não é dispensada imediatamente, será mastigada pelos membros da família que estiverem por perto, com a intenção de retirar dessa massa o restante de mel que ainda permanecia retido ali.

Potes de pólen também são mastigados para que o produto seja extraído da embalagem. Pela declaração do informante, havia interesse tanto no mel como nos potes de pólen, pois a identificação de sua localização em separado demonstra a perfeita convicção de que essa diferenciação era procurada. Também, os detalhes de coloração e sabores que mais apreciavam e que menos apreciavam, demonstra que o pólen apresentava certo apreço pelos índios da aldeia. Certamente os favos de cria eram mastigados da mesma maneira e, provavelmente, parte do cerume e da cera que envolvia toda a estrutura arquitetônica do interior também acabava por ser digerida, sem que se fizesse qualquer distinção.

Sobre a goma grudenta que em guarani m'byá é denominada ytxy, e foi citada para as abelhas jatei como sendo uma massa que estica e que a ciência denomina como própolis, é feito um preparo que tem praticamente a mesma condição da formulação descrita para o uso desse produto retirado das colméias das abelhas jatei. Segundo Karai Poty:

\footnotetext{
"se prepara com as folhas de uma planta que são torradas com essa goma, as crianças passam nas pernas e nas juntas dos pés e embaixo dos pés, e nas juntas dos braços também. É que pode ser usado para cuidar de não ter kãngue raxyi (que é traduzido como reumatismo), ou só para se proteger mesmo. As meninas passam no rosto quando ficam mais assim, mais velha e depois passam quando tem o primeiro filho. Quando tem o primeiro filho, passam o homem e a mulher, os dois passam, mas
} 
não é pintura, é por causa que é um costume de fazer assim, hoje não se faz mais isso, pelo menos aqui na aldeia (refere-se à Área Indígena da Barragem, aldeia Morro da Saudade, onde reside atualmente). Sabe que a gente sempre que tirava essa abelha procurava tirar bastante dessa goma pra poder fazer isso né, mas tinha bastante abelha por lá na aldeia (Rio das Cobras, PR), lá a gente sempre se virava e acabava achando as abelhas de alguma forma, se não tinha em caixa a gente saia pelo mato e achava, as vezes as crianças achavam perto da aldeia e vinham falar pros mais velhos e ai a gente ia tirar. Essa ei irapua eu nunca ouvi dizer que alguém tivesse em caixa, acho que nem daria certo, ela ia querer fazer a casa fora da caixa e também ela é brava mesmo ia morder todo mundo, pra tirar o mel ia ter que destruir mesmo e isso não ia dar certo na caixa né".

É necessário que se faça pelo menos uma observação ao se analisar o conteúdo das informações contidas nas explicações do índio Karai Poty. Trata-se da importância que foi dada sobre o uso da ytxy e a comparação que se foi construindo entre o passado, muito recente, de quando o informante morava em sua aldeia natal, e o presente na aldeia em que ele reside atualmente.

Pode-se afirmar que ao subjetivar seu julgamento de que “..hoje não se faz mais isso, pelo menos aqui na aldeia...", e ao se comparar esse dado com outro como o declarado mais adiante na mesma conversa: “...lá a gente sempre se virava e acabava achando as abelhas de alguma forma ...". Esse comportamento é um indicativo de que hoje sua ocupação e preocupação na atual aldeia, é talvez mais prementes, o suficiente para que alguns costumes sejam deixados apenas na memória e não exista uma tentativa em revivê-los. 
Não existe o mesmo "se virar" para encontrar as abelhas na pequena área da aldeia em que vive atualmente com sua família.

A todo o momento, durante a descrição oferecida pelo informante, notava-se uma certa expressão de nostalgia ao mesmo tempo em que ele se esforçava para tentar unir partes de sua lembrança. Nessa conversa outros parentes do informante que passaram pelo local agachavam-se junto aos que ali trocavam as informações, e participavam com um ou outro aceno ou mesmo com poucas palavras de afirmativas hora em português hora em seu idioma natal. De alguma maneira, também demonstraram que existia uma certa disposição em tentar resgatar todo aquele conhecimento e praticá-lo.

Um dos parentes de mais idade que passou pela conversa, o $\mathrm{Sr}$. Gumercindo, fez a seguinte observação sobre o assunto:

"o pai dele (referindo-se ao pai do informante Karai Poty), era uma pessoa que tinha muitas abelhas, mas naquela época era preciso ter as abelhas pra fazer o xarope de tosse e algumas outras coisas, as vezes as crianças precisavam de mel para curar algum problema sempre se podia dar o mel sem medo, tinha o preparo certo para cada coisa, era difícil precisar de médico (...) nem tinha tanto remédio de médico pra tomar e nem médico, agora a gente se acostumou a isso tudo e é difícil de perder esse jeito de usar o remédio do postinho, a gente fica pensando, será que esse remédio vai resolver? Esse que parece um comprimido, será que resolve mesmo, é tudo igual, se você for olhar mesmo é tudo igual, e a gente já viciou, ninguém sabe se isso resolve as coisas que a gente tem, as vezes as coisas que a gente tem não vai ser resolvida, já veio com a pessoa mesmo, os mais 
velhos nem preparam mais o chá e nem falam mais uma porção de coisas que se falava antigamente, todo mundo quer assistir a televisão e depois vai dormi ..."

A idéia de ter um posto de saúde na aldeia (o postinho), tem muitas interpretações, mas uma que é comum a todos os índios é que uma série de hábitos poderia mudar, se não existisse ali um posto de saúde.

O comportamento está mudando muito rapidamente, de uma geração para a outra, é possível que nem mesmo se saiba que um dia usaram determinadas ervas e insetos para o tratamento preventivo de sua saúde. E, se as doenças que os incomodam surgirem, em vez de recorrerem aos mais velhos ou ao pajé, primeiro eles vão ao postinho e depois vão ao médico fora da aldeia. É difícil saber em que ocasião poderia substituir o posto ou o próprio médico, por alguns dos costumes que eram comuns em tempos passados.

5.2.10 Etnoespécie: Ei ruxu ou akã motõ (idioma guarani, dialeto m’byá)

Descrição declarada pelo informante

"Essa é uma abelha de cor meio castanha, é como se fosse meio escuro, mas não é preta mesmo, ela é assim castanha escura que brilha no sol. Se você olha ela contra o sol parece de uma cor e se o sol bate nela de outro lado, fica de cor mais acastanhada e sempre brilha muito. E não é muito grande, mas é maior que a ei tapexua, não muito maior, acho que de um tamanho parecido com a ei guaxu, um pouco menor. Ela não tem ferrão e também não é muito nervosa, não fica assim querendo atacar todo mundo, é mansa e da pra tirar o mel delas sem ter muitos problemas. Mas, ela não é tão fácil de achar por causa que o ninho é meio 
escondido, não fica tão a vista e tem menos na mata que as outras abelhas, né. O ninho delas é no oco da árvore também e parece com a mandori. Esse nome engraçado que o guarani chama de akã motõ é por causa que ela parece com um botão, a cabeça dela parece um prego ou um botão, então tem esse nome. Nunca tirei para caixa, sempre tirava o mel delas na hora e levava pra casa assim na própria cera, o ninho tem bastante cera assim envolta do miolo mesmo onde estão as bolinhas com mel e as crias ficam protegidas, a cera dela é boa, é escurinha mas é bem boa para usar pra fazer velas".

Com base na descrição fornecida pelo informante sobre a etnoespécie ei ruxu ou akã motõ a análise realizada pelo Dr. Paulo NogueiraNeto, aponta para a pista taxonômica referente à espécie Melipona sp.

O informante declarou não conhecer o nome com que os brancos costumam se referir à etnoespécie ei ruxu ou akã motõ, porém a tradução para o idioma português é "cabeça de botão" ou "cabeça de prego". As duas traduções referem-se ao nome akã que é traduzido como "cabeça", e motõ que é traduzido como "botão", ou no caso também como "prego". Segundo declarou, nunca soube de qualquer pessoa que tenha tentado transferir um ninho dessas abelhas para uma caixa, ou ainda manter um ninho em estado natural para, posteriormente, retirar seus produtos.

\subsubsection{Utilização dos produtos}

A utilização dos produtos desta abelha não receberam maiores observações ou qualquer destaque. O informante apenas explicou que o mel podia ser consumido no próprio local onde procediam à abertura da colméia. Analisando suas declarações, nota-se que entre as abelhas usadas para o comparativo estão principalmente aquelas das quais o consumo do mel não 
mereceu muita importância além da alimentação, isto é, o mel não é usado para o preparo de algum alimento em específico, e não houve uma explanação mais detalhada de como o consumo se dava. É provável que o consumo de potes que armazenam o pólen e as partes do ninho que abrigam as crias foram consumidas sem que se desse qualquer tratamento diferente daquele a que se dava aos potes de mel. Possivelmente o consumo imediato era objetivo no que se refere ao aproveitamento do mel e outros produtos dessas abelhas.

Sobre a cera encontrada na colméia das ei ruxu ou akã moto que era retirada para o uso no artesanato e fabricação de velas e foi considerada um pouco mais escura, o que pode ser considerado um dado normal para as espécies das Meliponas, provavelmente era retirada com cerume e o batume. Não havendo uso específico para qualquer desses produtos presume-se que o ninho era destruído por completo na ação de retirada do mel e dos outros produtos dessas abelhas.

5.2.11 Etnoespécie: Mandori (idioma guarani, dialeto m’byá)

Descrição declarada pelo informante

"Essa abelha é diferente por causa que ela é meia ruivinha, cor de ferrugem (ky'a) assim como se fosse pelo lado do queimado, uma cor que não é preta e meia ruivinha mesmo, é como se fosse uma cor queimada, quando bate o sol ela fica de cor brilhante. Ela não é muito grande nem muito pequena, quer dizer ela é mais ou menos do tamanho menor que a ei raviju. Ela é brava e fica nervosa rápido, quando a gente mexe nela ela morde, tem que ir mexer preparado porque ela morde, não dói muito mas morde, é que ela também não tem ferrão é o jeito dela enfrentar quem mexe nela, ela é valente vem encima. O ninho delas é igual ao da ei raviju tem aquela entrada que parece 
com um barro escorrido, todo cheio de cortes, tem uma cara de meio sujo e ela prepara aquela massa com um pouco de cera, bem no meio é que ela prepara a entrada. Ela faz o buraquinho e depois envolta ela constrói essa parte que fica assim para fora, é bem envolta da entrada, sempre tem uma abelha que cuida da entrada e ela fica dentro da entrada. É mais difícil de encontrar essa abelha por causa dela não ficar um monte assim voando do lado de fora, mas ela não vai em árvore boa só em pau que já está velho e as vezes você até acha elas no tronco que está caído. Tem que ter bastante paciência para procurar, mas as vezes alguém andando pelo mato encontra e ai avisa, ai é mais fácil. Para por elas na caixa também é fácil, você tem que abrir o tronco bem devagar com cuidado por causa que pode quebrar o ninho, sempre envolta do centro do ninho onde ficam os favos com crias, existe uma porção de folhinhas de cera que estão sempre feitas uma encima da outra e todas são tortas mas sempre estão grudadas para uma segurar a outra, no meio delas fica uma camada forte envolta do ninho que protege bem o ninho, se você quando for mexer não tomar cuidado estraga tudo. As bolinhas de mel tem época que estão bem cheias e outras épocas mais vazias, depende se está muito calor ou não, no frio elas trabalham em um horário diferente, não é o dia todo, ai parece que tem menos mel, mas ai também não vale a pena abrir a colméia para tirar mel se você já sabe que tem menos mel. Quando você colocar em caixa ela fica meia confusa na hora que você coloca, é bom colocar um pedaço do ninho que está inteiro e um 
pouco daquelas folhas que estão envolta, aquelas folhas de cera que são mais macias e não tão escuras as abelhas gostam que você coloque, elas arrumam tudo muito rápido, logo elas vão fechando todas as rachaduras da caixa, a caixa não pode ser muito velha também. Depois que elas se acomodarem acabou o problema, elas vão construindo devagar os favinhos do ladinho um do outro e vão ficando. O mel não é uma maravilha, mas tem gosto de mel, a gente usa para comer assim mesmo quando tira da abelha, mastiga e pronto. Mesmo se guardar um pouco ele é usado para a gente comer mesmo, pode até adoçar alguma coisa, mas não lembro agora de nada. Elas costumam deixar o lugar que vai ter filhotes, assim os favos onde é o ninho cheio de mel, se você mastiga sai todo mel e ai pode cuspir o resto. O mel só tem serventia para comer mesmo. A cera tem partes que é bem mais limpa e tem parte que é escura e suja, para fazer uso dela nas velas é bom usar a que está limpa, que é um pouco mais clara que a que está meio suja e é mais dura e seca.

Com base na descrição fornecida pelo informante sobre a etnoespécie madori a análise realizada pelo Dr. Paulo Nogueira-Neto, aponta para a pista taxonômica referente à espécie Melipona marginata.

O informante declarou que a etnoespécie madori recebe o nome de "maduri" pelos brancos. Pode-se perceber a pequena variação da nomenclatura popular onde o empréstimo do nome foi adequado ao som (fonema) da fala dos índios. Embora tenha declarado que manteve duas caixas em seu meliponário, explicou que isso não era muito comum, devido ao mel não ser o mais apreciado pelos índios. 


\subsubsection{Utilização dos produtos}

Embora a descrição desta abelha tenha revelado alguns detalhes mais esclarecedores a respeito de sua biologia e arquitetura do ninho, os produtos citados espontaneamente para uso foram apenas o mel e a cera, sendo que o mel era consumido como alimento diretamente dos favos ou, como o informante declarou, podendo ser usado para adoçar algum alimento, mas do qual não se recordava. Como o índio Karai Poty chegou a ter duas caixas dessas abelhas,

“... que tirei do tronco, que parecia ter uma grande colméia pela quantia das abelhas que começaram a se movimentar e voar pra cá e pra lá, mas que depois vi que era mais ou menos igual a outras que eu já tinha aberto antes (...) quando coloquei na caixa ela foi se acostumando e eu abria ela de vez em quando para ver como estava, quando tirei os favos com mel e alguns outros do ninho que também estavam com mel vi que ela estava crescendo meio devagar, comemos o mel na hora, não era muita coisa..."

Certamente para a transferência da natureza para uma caixa a colméia natural foi praticamente destruída, parte virou alimento para os índios e parte da cera deve ter sido reservada para o artesanato e para a fabricação de velas. Pode-se considerar que o mel que não retornou para a caixa foi consumido com os potes e que provavelmente, uma grande parte da cera e cerume que foi retirada da colméia natural, também não chegou a ser usada na instalação da nova colméia, ou no artesanato, uma vez que esses favos devem ter sido mastigados. Desta maneira é bem provável que teriam sido engolidos ou cuspidos, mesmo que fossem cuspidos, em parte a cera e o cerume que constituem o interior dos ninhos também deveriam ter sido engolido pois, dificilmente, se consegue separar tão bem esses produtos na mastigação. 
Como em outras ocasiões o informante recomendara a colocação de uma pequena quantidade de cera e de ninhos com crias na caixa para que a transferência ocorresse com êxito, acredita-se que uma parte do ninho com as células já desenvolvidas, com larvas pequenas, ou mesmo com ovos, deveria ser consumida ali mesmo, durante a retirada do tronco. Com isso se chega à conclusão de que, além do mel, também se consumiam alvéolos com ovos e com crias.

Algumas peças de artesanato são lustradas com a cera e o cerume, misturados numa massa que os índios costumavam guardar para essa finalidade. A cera de melhor qualidade é usada para a fabricação de velas; os índios preferem as ceras mais claras para essa ocupação, no entanto, na falta desta, qualquer outra servia para essa função.

5.2.12 Etnoespécie: Ei tapexua (idioma guarani, dialeto m’byá)

Descrição declarada pelo informante

"É uma abelha pequena, do tamanho parecido com a ei rapua, ela não tem ferrão e é pretinha, as vezes que você mexe com ela, ela acaba indo no cabelo e enrola no fio de cabelo, mas não causa mais problemas que isso, é mansinha, não dá pra se preocupar, fora ela grudar no cabelo não tem mais problema. O ninho delas da na madeira, é como se fosse um funil grande e do lado de fora tem uma boca larga, assim uma bocona larga e comprida que vai afinando até entrar na madeira, por isso que a gente fala que parece um funil. $O$ ninho mesmo tem pouco mel, nas bolinhas de mel tem pouco mel. $O$ ninho não é muito diferente de outras abelhas por dentro, ele é bem parecido, geralmente vi essa abelha menos e ela dá no tronco assim que está oco, mas não é assim podre". 
Com base na descrição fornecida pelo informante sobre a etnoespécie ei tapexua a análise realizada pelo Dr. Paulo Nogueira-Neto, aponta para a pista taxonômica referente à espécie Cephalotrigona capitata.

O informante declarou que a etnoespécie ei tapexua recebe a denominação de "mombuca" pelos brancos e que desconhece qualquer pessoa que tenha tentado manter essas abelhas em caixas ou trazer para a aldeia os troncos onde ocorre a nidificação.

\subsubsection{Utilização dos produtos}

Poucos comentários foram feitos sobre essa abelha e mesmo sobre o uso ou conhecimento de seus produtos. Como no caso das abelhas que não foram semidomesticadas, retiradas da natureza para as caixas previamente construídas para essa finalidade, a informação a respeito do consumo de seus produtos restringiu-se apenas às declarações de que o mel era consumido como alimento, diretamente dos potes, sem qualquer menção a respeito de outros usos ou mesmo, de armazenamento.

O informante também se restringiu a dizer que a cera era usada para fazer velas e, se necessário, usavam parte da cera para lustrar peças de artesanato.

5.2.13 Etnoespécie: Kraxai (idioma guarani, dialeto m’byá)

Descrição declarada pelo informante

"A gente dá esse nome por que quando você vê de
longe, quando olha assim pra árvore onde ela faz o
ninho dela, de longe você vê que parece um papo
de bugio com um cortinho, no meio é como se fosse
a boca, mas é a entrada dela, fica assim na posição
como se fosse um papo do bugio mesmo, que esta
na madeira, é a cara do papo. Ela é uma abelha 
pretinha e é bem pequena, é menor que a jatei. Dá um mel bem suave. O ninho é de bolinhas bem pequenas e tem uma porção bem grudadinha uma na outra. Nem dá para pensar em por em caixa, sempre encontrei elas em tronco que pra tirar tem que abrir e estraga tudo, tem que comer o mel e não tem mais o que fazer".

Com base na descrição fornecida pelo informante sobre a etnoespécie kraxai, segundo a análise realizada pelo Dr. Paulo Nogueira-Neto, conforme sua comunicação pessoal: "não é possível com essas informações dizer qual é a espécie, poderíamos correr o risco de errar, então é melhor que coloquemos apenas como não identificada".

O informante desconhece qual a nomenclatura usada para essa etnoespécie no idioma português. Também, neste caso, não conheceu qualquer pessoa que tenha tentado transferir essas abelhas para caixas ou mesmo que tenha tentado manter o ninho no tronco encontrado naturalmente, para a extração do mel ou qualquer outro produto.

\subsubsection{Utilização dos produtos}

O mel dessa abelha é consumido como alimento diretamente retirado da colméia. A única informação que o informante deu a respeito desse produto é que ele é bastante suave e que se for procurado nas matas da aldeia Rio Branco - SP, é bem possível que alguma colméia ainda seja localizada. Os potes de mel eram mastigados para deles se extrair o seu conteúdo. Provavelmente o comportamento com relação aos potes com pólen e crias era o mesmo, porém nenhum comentário foi feito a esse respeito.

A cera e o cerume que compõem a arquitetura interna do ninho dessas abelhas foi considerado pelo informante como de uso para a fabricação de velas. Não foram fornecidos mais detalhes de outras utilidades para tais produtos. 
Algumas informações obtidas com outros pesquisadores a respeito do costume dos Guarani sobre as abelhas em seu cotidiano são interessantes e podem facilitar o entendimento sobre declarações dos índios contidas neste trabalho. Como exemplo: o Prof. Dr. Waldemar Ferreira Netto (comunicação pessoal), um especialista em língua tupi, da Faculdade de Filosofia, Letras e Ciências Humanas (FFLCH), Universidade de São Paulo, comentou a respeito de crianças Guarani que, em certas ocasiões de sua visita em 1992 à aldeia na Área do Rio Silveira (SP), surgiam com partes dos ninhos de abelhas, oferecendo para os membros de sua equipe de pesquisa:

“...as crianças, vinham em nossa direção trazendo na mão, segurando na mão sem nenhuma proteção, partes de ninhos de abelhas, que continham nos alvéolos os ovos, larvas e um pouco de mel, (...) faziam isso como se estivessem nos oferecendo um presente ou algo que representava ter um certo valor, que por sinal deveria ser saboroso..."

O professor relatou que essas crianças cortavam pedaços dos ninhos com as mãos e os colocavam na boca, ou mesmo mordiam o pedaço, mastigando aquilo como se fosse uma especialidade, isto é, um produto que não está disponível comumente. Mastigavam o produto e o engoliam e outras vezes "punham fora" uma massa restante que, era, sem dúvida, a cera.

Nas observações relatadas pelo professor que visitava a aldeia com alunos de pós-graduação de seu curso de língua Tupi antigo, e outros pesquisadores, verifica-se que era notada a presença tanto de crias em estado larval como os ovos e depósitos de mel. Tais características observadas são insuficientes para determinar se as estruturas foram retiradas de espécies de abelhas com ferrão ou de abelhas sem ferrão. No entanto, a probabilidade das crianças estarem oferecendo partes de ninhos de abelhas sem ferrão, é considerável, visto que os incômodos causados por abelhas com ferrão em ocasiões desse tipo, seriam de fácil percepção. O cheiro que se espalharia 
pelo ar iria atrair um grande número de abelhas, que dificilmente não seriam notadas, porém é apenas uma suposição.

Como o professor não mencionou qualquer dado a respeito de abelhas que por ventura acompanhavam ou tentavam retirar o mel dos favos que estavam em poder das crianças, Ihe foi perguntado se, naquela ocasião, havia abelhas voando por ali, e mesmo se não havia abelhas que tentassem pousar nos pedaços que as crianças mantinham sob seu poder. O professor disse que não lembrava de abelhas na ocasião, salientando que pelo menos "aquelas conhecidas pelos índios como ei guaxu, ou "oropa" ou "europa", não estavam ali, pois são muito fáceis de serem percebidas pois picam dolorido".

Mesmo outros detalhes não tendo sido explorados na conversa com o professor Ferreira Netto, os poucos dados fornecidos podem confirmar com alguma segurança que as crianças possuíam um produto que deveria ter sido extraído de alguma colméia da natureza, pois não se têm notícias de que naquela aldeia existissem caixas que abrigassem qualquer espécie de abelhas, naquela época. Também é aceitável o fato de que a extração do produto em questão, deva ter ocorrido naquela mesma tarde, isto é, na tarde em que a equipe de pesquisadores visitava o aldeamento.

Tais observações confirmam os costumes entomofágicos entre os Guarani, além de sustentar a hipótese de que esse costume ainda está presente entre esses índios, fortalecendo várias declarações que foram colhidas em outra aldeia como foi o caso das que forneceram material de estudo para o presente trabalho.

No quadro a seguir estão apresentados os produtos das abelhas sem ferrão declarados como de uso pelos Guarani. 


\begin{tabular}{lcccccc}
\hline \multirow{2}{*}{ Etnoespécie } & \multicolumn{5}{c}{ produtos da etnoespécie que são utilizados } \\
& mel & pólen & cera & cerume & própolis & crias \\
\hline Jatei & $\mathrm{X}$ & $\mathrm{X}$ & $\mathrm{X}$ & $\mathrm{X}$ & $\mathrm{X}$ & $\mathrm{X}$ \\
Ei pytã & $\mathrm{X}$ & $\mathrm{X}$ & $\mathrm{X}$ & $\mathrm{X}$ & & $\mathrm{X}$ \\
Guarykua & $\mathrm{X}$ & & $\mathrm{X}$ & $\mathrm{X}$ & $\mathrm{X}$ & \\
Ei raviju & $\mathrm{X}$ & & $\mathrm{X}$ & $\mathrm{X}$ & & \\
Yvi ei & $\mathrm{X}$ & & $\mathrm{X}$ & & & $\mathrm{X}$ \\
Ei tata & & & $\mathrm{X}$ & $\mathrm{X}$ & & \\
Ei mirĩ & $\mathrm{X}$ & & $\mathrm{X}$ & $\mathrm{X}$ & & $\mathrm{X}$ \\
Ei miri ‘i & $\mathrm{X}$ & & $\mathrm{X}$ & $\mathrm{X}$ & & $\mathrm{X}$ \\
Ei rapua & $\mathrm{X}$ & $\mathrm{X}$ & $\mathrm{X}$ & $\mathrm{X}$ & $\mathrm{X}$ & $\mathrm{X}$ \\
Ei ruxu ou Akã moto & $\mathrm{X}$ & $\mathrm{X}$ & $\mathrm{X}$ & $\mathrm{X}$ & & $\mathrm{X}$ \\
Mandori & $\mathrm{X}$ & & $\mathrm{X}$ & $\mathrm{X}$ & & $\mathrm{X}$ \\
Ei tapexua & $\mathrm{X}$ & & $\mathrm{X}$ & & & \\
Kraxai & $\mathrm{X}$ & & $\mathrm{X}$ & & & \\
\hline
\end{tabular}

Quadro 3 - Uso de produtos de cada espécie de abelhas sem ferrão

\section{3 (B) Abelhas com ferrão}

Entre as sete etnoespécies de abelhas com ferrão que foram mencionadas pelos informantes, figuraram apenas abelhas que a ciência agrupa em dois diferentes gêneros: Bombus, onde os Guarani reuniram as abelhas com ferrão que eles denominam como a etnoespécie mamanga e (seis etnoespécies), e o gênero Apis, representado pela abelha denominada pelos Guarani como a etnoespécie ei guaxu.

As descrições oferecidas para essas etnoespécies de abelhas não foram tão pormenorizadas como no caso das abelhas sem ferrão. Porém para a etnoespécie ei guaxu, como se pode verificar desde o início deste trabalho, ouve um detalhamento mais minucioso. Além disso, essa abelha foi usada 
permanentemente para o comparativo entre as etnoespécies do grupo de abelhas sem ferrão com as abelhas com ferrão.

5.3.1 Etnoespécie: Mamanga (idioma guarani, dialeto m’byá)

Descrição declarada pelo informante

\begin{abstract}
"Essa abelha é grande e preta, tem um ferrão grande e costuma picar mesmo, as vezes pica do nada, como ela é preta, bem preta mesmo, né, você pega nela sem perceber se ela está em um galho em uma fruta, ai ela fica brava, fica muito brava e nem da tempo de fugir ela vem encima e pica mesmo. Ela faz o ninho na terra ou bem encima do tronco, perto da terra. Quando ela voa de longe já da pra saber que é a mamanga, faz um barulhão e ela é grandona, só de ver já assusta."
\end{abstract}

5.3.2 Etnoespécie: Mamanga guaxu (idioma guarani, dialeto m’byá)

Descrição Declarada pelo informante

"Entre todas as mamanga a mamanga guaxu é a
maior, ela é bem grandona mesmo e parece um
bizorão, ela é pretona e tem mania de perseguir a
gente. Você ta assim num lugar e mexe nela, ela sai
voando igual a um marimbondo mesmo, sai pra
picar e se pegar ai dói muito, pica bem dolorido.
Essa parece que gosta de perseguir a gente se você
passa em um barranco que tem o buraco dela e
parar ali, é bem capaz dela vir atrás sem motivo
nenhum. As vezes elas resolviam fazer o ninho num
lugar que a gente tem que passar, pode ser até um
ninho no chão mesmo ou perto do chão na parte 
perto do tronco mesmo, é sempre na terra mesmo. Ai tinha que espantar elas ou arriscar tomar uma ferroada bem doída. Quando uma abelhona dessas está perseguindo a gente não tem ninguém que escapa de levar uma ferroada".

5.3.3 Etnoespécie: Mamanga pytã (idioma guarani, dialeto m’byá)

Descrição Declarada pelo informante

\begin{abstract}
"Ela é meio avermelhada, bom o nome dela é de vermelho mesmo né. É que pytã quer dizer vermelho. Ela é assim de cor meio vermelho mais para o marrom, parece ser mais castanha no geral, se você não olhar com cuidado pode até achar que ela é preta, mas é uma mistura, no sol dá pra ver que é meio brilhante de cor misturada, fica até parecendo que é castanha".
\end{abstract}

5.3.4 Etnoespécie: Mamanga uũ (idioma guarani, dialeto m’byá)

Descrição Declarada pelo informante

“É uma inteira preta, inteirinha preta mesmo não importa como você está olhando pra ela você vai sempre ver que é preta mesmo, Essa também é só olhar o nome dela que da pra saber que é mamanga preta, porque uũ quer dizer que é preto mesmo."

5.3.5 Etnoespécie: Mamanga pará (idioma guarani, dialeto m’byá)

Descrição Declarada pelo informante

"Essa é uma que tem uma lista na barriga, parece com a barriga da guarykua mais ou menos, assim 
por causa da lista, mas ela tem uma ferroada doída também, então nem é bom arriscar deixar ela te pegar".

5.3.6 Etnoespécie: Mamanga ĩ (idioma guarani, dialeto m’byá)

Descrição Declarada pelo informante

"É uma menor é a mais pequena das mamanga ela é bem parecida com a ei raviju. Ela é assim maior que uma mosca dessas comuns, um pouco maior, na barriga dela tem umas listas. É brava também e pica mesmo igual as outras mamanga grandes, ela vem encima e você pode correr que ela persegue até pegar, não pode nunca mexer no ninho. O ninho delas só dá no chão como as mamanga das grandes, dentro do ninho tem um lugar que elas grudam o pó das plantas, assim o pólen, elas deixam lá para que os filhotes possam comer aquilo ali".

Segundo a declaração do informante:

"os brancos costumam chamar todas as mamanga por alguns nomes copiados da língua do índio mas eles erram e misturam todas as mamanga, e nunca acertam chamam todas de: "mamangá", "mamangaba", "mamangava", tanto faz qual delas é, sempre falam só isso, mesmo elas sendo muito diferentes. O juruá copiou o nome que nós sempre chamamos essa abelhona, mas ele não percebe que uma é diferente da outra". 
Sobre o uso dos produtos das mamanga o informante declarou que ela não produz mel que em sua concepção seria aquilo que poderia fazer com que se tentasse qualquer manuseio com esse inseto. Perguntado sobre outros usos para qualquer produto dessas abelhas, a resposta foi muito clara: "ela não faz nada que nos interesse, pode até ser que os mais velhos possam saber eu nunca ouvi dizer que tinha alguma serventia para nós".

Persistindo na questão de uso de seus produtos, a indagação se deu a respeito especificamente sobre a mamanga $\tilde{\imath}$, com relação ao pólen que foi mencionado pelo informante como sendo o pó das plantas que essa abelha armazena no interior do ninho. A intenção foi de incentivar o informante a falar a esse respeito, uma vez que durante todo o trabalho foi detectado que o uso dos produtos de qualquer abelha, isto é a utilização dos produtos como alimento ou para outra finalidade, suscitava uma revelação de que outros usos além da alimentação podiam surgir. No caso do pólen armazenado por essa abelha, o informante explicou que a quantia era pequena:

\footnotetext{
"é que a mamanga ĩ é como qualquer outra abelha dessas ela faz pouca coisa, traz pouco das plantas, parece que está meio sujo por causa que ela não é como as outras abelhas, como que vou explicar ... ela não tem assim uma maneira de fazer o pólen que dá pra ver que está limpo, e é no chão, sempre é mais sujo mesmo. Depois ela é brava de mais, eu até experimentei aquele pozinho, mas não tem nem o suficiente para usar e tem que matar ela pra que ela não possa meter o ferrão, não vale a pena".
}

5.3.7 Etnoespécie: Ei guaxu (idioma guarani, dialeto m’byá)

Descrição Declarada pelo informante

"Bom a abelha que nós chamamos de ei guaxu e o jurua chama de "europa", é aquela mais comum de 
todas que picam, é que ela tem um ferrão e não tem dó, pra ela não importa quem seja se for gente ou se for assim um animal da casa, qualquer coisa, ela pica e dói muito. Quando você olha essa abelha você pensa que é tudo é igual, mas quando você olha mesmo, quando fica prestando atenção nelas você vai perceber né que ela é bem misturada né. $\mathrm{Na}$ mesma família dela, tem abelha preta, tem abelha mais clara, mais escura, com listinha amarela na barriga, outra é maior, outra é mais pequena um pouco e tem até aquelas que são mais castanhas que as outras e com lista também, mas todas são da mesma família. A ei guaxu tem um ninho sempre grande e sempre com muita abelha, ela dá um mel fabuloso, forte e sempre tem muito mel dentro do ninho delas, elas são muito bravas e valente também, antigamente, muito antes que eu tivesse abelha, meu pai contava que dava pra ter uma porção dessas abelhas e não tinha qualquer problema, elas eram com ferrão, mas não eram tão brava, ele dizia que todo mundo tinha como mexer nelas, era só tomar cuidado para não deixar ela muito brava que dava tudo certo, podia mexer nela qualquer hora sem problema, depois de um tempo pra cá elas foram ficando muito bravas e cada vez mais ignorantes, ela nem distingue uma pessoa da outra, é tudo igual, criança, criação, tudo, ela vem encima pra picar mesmo, se uma pica você, já vem outra e pica e ela incomoda muito, vai dentro da casa em qualquer coisa e fica brava logo, se você tentar espantar ela ai é que a coisa piora mesmo, logo depois de que veio uma já vem de monte e não tem jeito, é muito perigoso. Pra ter na caixa é muito 
bom se a gente pensar só no mel e na cera ela sempre dá muito mel e a família cria rápido de mais, ai é que fica mais perigoso, elas fazem aquela bola do lado de fora da caixa é sinal que vão sair. Quando elas saem parece que a família ta grande demais ai elas saem voando e param em qualquer lugar, num galho, pode ser ou dentro da casa da gente, é muita abelha, é muito perigoso. Se você tem uma outra caixa pode até pôr por perto, pode passar um pouco de mel ou deixar um pedaço de ninho dentro, elas podem entrar e começar a fazer outro ninho, não importa se a caixa é grande ou pequena, não pode ser muito pequena, elas entram e começam a trabalhar no mesmo dia e já dá pra ver aqueles favos indo se formando, é bem diferente da jatei ou qualquer outra que não tem ferrão, não tem aquela folha envolta, é uma porção de favo que vão se formando e elas vão fazendo tudo de cera, uma cera amarelinha, e depois enchem uma parte com mel e uma parte com pozinho né, as vezes de muitas cores, e também põe os filhotes. Dentro do ninho mesmo é muita abelha andando de um lado pro outro e fazendo alguma coisa, sempre tem umas abelhas do lado da mãe de todas elas, ela também é diferente é mais comprida e fica botando ovo nas casinhas. Pra mexer no ninho da ei guaxu tem que ter muita prática e muita proteção, elas picam mesmo, tive umas quinze caixas, mas tive que desistir elas ficaram esquisitas de mais, eu já estava ficando com medo né, se ataca uma criança, ai não dá certo". 
Com base na descrição fornecida pelo informante sobre a etnoespécie ei guaxu a análise realizada pelo Dr. Paulo Nogueira-Neto, aponta para a pista taxonômica referente à espécie Apis mellifera.

O informante declarou que a etnoespécie ei guaxu recebe a denominação de "abelha europa" pelos brancos. Considerou uma abelha que apresenta uma grande produtividade de mel e cera, produzindo um mel forte e saboroso. Manteve caixas espalhadas entre o meliponário, e algumas mais próximas entre si, numa área próxima, o que poderia ser considerado, a grosso modo, como um apiário rudimentar. No total declarou que chegou a quinze caixas; entre elas existiam algumas fabricadas especificamente para abrigar 0 ninho das ei guaxu, outras caixas eram grandes e embora não tivessem sido fabricadas para essa finalidade, acabavam servindo para abrigar essas abelhas e deixá-las na mata por perto da aldeia. Normalmente rendiam uma grande quantidade de mel e muita cera, como já foi descrito anteriormente.

Com o passar do tempo essas abelhas começaram a apresentar um grau de agressividade muito grande e colocar em risco a vida das pessoas e das criações na aldeia:

\footnotetext{
"tive que parar com elas por causa que ficaram esquisitas, sempre estavam nervosas e não respeitavam nada nem ninguém, entravam em nossa casa e iam em tudo e sempre alguém tomava uma picada, também tinha um problema que as vezes elas saiam com a família toda e entravam em casa, ficava um cacho delas assim num canto qualquer, um bola grande de abelha, ali tinha muita abelha e nem sempre a gente podia tirar sem ter problemas, comecei a desistir, elas ficaram muito perigosas, algumas que estavam longe de casa ainda ficaram por algum tempo, depois quando eu vim para esta aldeia eu deixei tudo pra lá".
} 


\subsubsection{Utilização dos produtos das abelhas com ferrão}

O mel das abelhas ei guaxu é muito apreciado como alimento pelos Guarani. A quantia de mel que pode ser obtido em cada extração é um estimulante para que esse produto seja procurado pelos índios. No entanto, a conhecida agressividade dessa espécie (Apis mellifera) afasta a possibilidade de manipulação a não ser que seja obedecida uma série de procedimentos técnicos, para que a criação racional da espécie não seja extremamente perigosa.

Quanto ao uso para o preparado de produtos da medicina tradicional dos Guarani, poucas referências foram citadas não havendo ênfase a respeito de seu uso ou de qualquer dos produtos dessas abelhas. Em vez disso, o informante declarou apenas que (...) as vezes se preparava algum chá que poderia ser adoçado com o mel das ei guaxu, mas é preferível usar o mel da jatei ou da ei pytã (...).

O mel da abelha "ei guaxu" não é usado por mulheres e crianças em determinadas épocas e fases da vida ou mesmo se estiverem sob alguma dieta, como já foi discutido anteriormente. Tal fator não foi explorado pormenorizadamente neste estudo, porém nas informações espontâneas obtidas durante as conversas com os índios pode-se verificar que todos declaram que o mel é muito forte e que não é costume que as mulheres, meninas e crianças usem o mel em alguma fase da vida.

Atualmente, o uso do açúcar refinado e mesmo de adoçante é habitual entre os moradores da aldeia. Em nenhuma das moradias visitadas durante o estudo foi encontrado mel de qualquer natureza. Embora todos os índios soubessem da existência desse produto, provavelmente por se tratar de um produto de custo financeiro muito alto e difícil de ser encontrado na natureza, o mel foi definitivamente substituído pelo açúcar refinado que pode ser obtido de diversas formas muito simples: cesta básica fornecida pelos governos, por entidades filantrópicas, por religiosos de diversos segmentos do cristianismo, como também pode ser adquirido a menos de um quilometro em 
um dos bares estabelecidos nas margens da estrada que chega até a aldeia e em um mercadinho localizado a cerca de dois quilômetros.

Outro produto das abelhas ei guaxu citado pelos Guarani, é a cera. É um produto abundante nas colméias dessa abelha e é utilizado para confeccionar as velas usadas na casa de reza (opy) em diferentes cerimônias religiosas. A cera dessas abelhas é considerada pelos índios como sendo: "molinha, clara e com o cheiro bom". Sua extração implica na destruição de parte da colméia e sem dúvida pode provocar uma série de transtornos para as pessoas que estiverem por perto, pois as abelhas podem se tornar mais agressivas quando o procedimento para a retirada da cera é menos sustentável e mais destrutivo.

Alguns problemas ocorrem durante a manipulação da cera para o uso na fabricação das velas. Para que seja usada nesse fabrico é necessário que seja derretida e a operação deverá ocorrer com a cera em estado líquido, isto é, ainda bem quente. É sabido que ao seguir essa seqüência o cheiro exalado durante a operação irá atrair um grande número de abelhas, situação que se torna perigosa, pois essas abelhas podem atacar as pessoas que tentarem espantá-las.

Em certa ocasião (2002) fui pessoalmente consultado pelo cacique da aldeia Morro da Saudade, que me fez uma solicitação: precisava conseguir um pouco de cera de abelhas para poderem fabricar velas para uma cerimônia que ocorreria na casa de rezas. Perguntei se não seria mais interessante se saíssemos à procura pela mata existente próximo da aldeia e ele disse que haviam procurado, mas não encontraram nada. Com muita objetividade o cacique me explicou que poderia ser de ei guaxu, que é mais fácil de ser encontrada no mercado de produtos apícolas. Presenteei a aldeia com um tablete de cera pura de Apis mellifera, comprada de um distribuidor atacadista de produtos apícolas do estado de São Paulo.

Ao entregar a cera para o cacique, que na ocasião estava com outros índios de idade mais avançada, não foi mencionado que se tratava de 
cera de Apis, apenas the foi entregue um pacote em mãos. $O$ cacique abriu 0 pacote e passou o tablete para a mão de outro índio que imediatamente cheirou o produto e disse que era de ei guxu e que era cera limpa e nova. 0 tablete passou pelas mãos de pelo menos cinco pessoas antes de retornar ás mãos do cacique e todas fizeram a mesma ação, isto é, imediatamente após segurar o tablete a primeira coisa foi levar até bem perto das narinas e cheirar com força e os comentários que se fizeram foram de que era cera limpa.

Indagados informalmente, na mesma ocasião, sobre o que os levaram a achar que a cera era limpa e nova, ouvi a seguinte explicação:

\begin{abstract}
"quando você pega cera para fazer essa pedra de cera, tem que ser de muitas abelhas (referindo-se a muitas colméias diferentes), é mais fácil pegar bastante de uma e de outra e de outra, ai vem cera velha junto, mais escura e que as vezes tem coisas misturada. Essa cera aqui foi escolhida, pegaram um pouquinho de cada abelha e escolheram pegar a parte mais clara que é mais nova".
\end{abstract}

Outro índio que estava na mesma roda de conversa, mas que não havia cheirado a cera, teceu o seguinte comentário:

\footnotetext{
"quando você derrete a cera, ai você usa ela no que você quer e vai sobrando e você junta e derrete e esquenta e derrete, ela perde o cheiro de abelha e fica com cheiro enjoado e as vezes escurece, essa ai só de olhar já sabe que só derreteu para fazer a pedra mesmo, ela ainda tem o cheiro da casa da ei guaxu".
}

Tais observações revelam que o conhecimento daqueles índios, alguns daquela aldeia (Morro da Saudade) e outros visitantes de outras regiões do estado de São Paulo, que estavam naquele momento conversando, vai além 
do saber a respeito da abelha ou de sua sociabilidade. Apresentaram um conhecimento sobre a manipulação de um produto como a cera, com explicações detalhadas a respeito de como deveria ter sido a coleta daquele produto, para que ele estivesse com aquela aparência e aroma característicos.

As pessoas que estavam ali, falavam o idioma português com um pouco de dificuldade, trocando palavras e perguntando ao cacique, no idioma guarani, para completar a frase em português. É provável que o conhecimento a respeito da qualidade da cera e sua pronta identificação tivesse sido adquirido manipulando a cera em ocasiões que se reportaram em sua memória para encontrarem a resposta às indagação que lhes foram feitas, ou mesmo tivessem acompanhado a manipulação de outros índios como prática de aprendizagem ou ainda de sociabilidade, no preparo de produtos que dependiam de cera de abelhas.

De qualquer forma, esse não é um conhecimento que pôde ser observado entre os mais jovens. Nenhum jovem estava naquela roda de conversas e, mais tarde o mesmo tablete de cera foi apresentado a um rapaz de 16 anos de idade. Seu comportamento foi distinto dos anteriores: pegou o pacote desembrulhou e sorriu perguntando o que era aquilo. Não fez como os outros índios mais velhos que num ato único cheiravam 0 tablete e o manipulavam, depois cheiravam as mãos.

\subsection{C) Vespas}

A categoria denominada kavy (vespas), englobou cinco etnoespécies de vespídeos das quais apenas uma é informada como produtora de mel. As descrições apresentadas pelos informantes revelam que todas as kavy são conhecidas como agressivas e que todas atacam o homem. Para descrevê-las, em alguns casos, foram usadas abelhas sem ferrão como comparativo fenotípico, assim como a abelha com ferrão ei guaxu.

Nas explicações descritivas sobre os vespídeos, os informantes apresentaram um número maior de atributos antropomórficos, qualificando-os 
negativamente, e colocando-os na extremidade oposta, se comparadas às abelhas sem ferrão, principalmente à espécie que os índios denominam como sendo a etnoespécie jatei, que serviu para apresentar a outra extremidade da escala (imaginária) de bom/ruim, calma/nervosa, mansa/feroz.

Os ninhos das vespas recebem um nome específico e, segundo o informante Karai Poty, podem ser chamados de etã. A palavra etã apareceu em algumas conversas entre os índios e foi traduzida pelo informante como sendo "a colônia" ou "a comunidade", isto quando se refere a toda a comunidade. Assim, kavy etã, é como se referem os Guarani aos ninhos de vespídeos em geral, isto é, qualquer vespa que não produza mel. No entanto a palavra eixu também é usada para se referir aos ninhos de vespídeos e de abelhas com ferrão construídos em forma arredondada, seja em galhos de árvores, troncos, ou em outro local qualquer. Para os ninhos de vespas construídos no chão existe uma designação específica, eixu guaxu, segundo o informante.

Pode existir uma confusão com essas palavras, pois como veremos mais adiante uma das etnoespécies de vespas recebe a denominação eixu guaxu. Traduzidas as duas palavras podem significar respectivamente, "ninho de vespas" e "grande", porém referem-se conjuntamente às vespas que constroem o ninho no chão.

A seguir estão enumeradas as etnoespécies de vespídeos mencionados pelo informante, na mesma ordem em que foram descritas.

5.4.1 Etnoespécie: Kavy typexaĩ (idioma guarani, dialeto m’byá)

Descrição Declarada pelo informante

"Essa é meio avermelhada, meio ferrugem, uma cor que não dá pra dizer direito que definição ela tem. Ela costuma dar embaixo do telhado da casa, aparece de uma hora pra outra, quando se percebe ela está lá fazendo seu ninho. Ela é brava e 
quando resolve atacar a pessoa ela vai sem dó e ataca direto no olho da pessoa, ela é meio besta, assim, não dá para imaginar que ela ta lá tão impaciente e que vai atacar a gente, é ruim mesmo porque ataca sem motivo nenhum, como se alguém tivesse fazendo mal pra ela. É que pela palavra né, typexaĩ, você deve pensar que a gente está querendo dizer que ela é cega, pode parecer que ela é cega, mas na verdade quer dizer que ela pica o olho da pessoa que se ela atacar ela vai picar no olho da pessoa. O ninho dela é completamente diferente das abelhas mesmo, ela até pode fazer a casa parecendo um pedaço de uma casa de abelha, mas só um pedaço, é como se você tivesse cortado um pedaço do favo, bem assim, tirado um pedaço, e ela nunca acaba tudo, é só aquele pedaço mesmo. Ai ela fica ali naquele pedaço e vai criando e todo dia ela mexe aqui e ali e vai aumentando aquele pedacinho vai aumentando de tamanho, mas nunca vai virar uma bola ou nada, vai sempre continuar sendo um pedaço, parece que ela nem pensa em terminar nada, ela é estranha mesmo. O ninho dela a gente chama de etã, então você pode chamar de kavy etã quando estiver falando de uma vespa dessas que não dá mel. É bom se você vê que ela está começando a ficar ali já ir logo dando um jeito de tirar elas para que não corra o risco de tomar uma picada, se pegar no olho pode até ficar cego, eu acho que deve ficar cego se pegar no olho, é que ela pica muito doído". 
5.4.2 Etnoespécie: Kavy taturã (idioma guarani, dialeto m’byá)

Descrição Declarada pelo informante

"É uma vespa de cor preta, pretinha mesmo, ela é de tamanho mais ou menos igual ao da guarykua, ela é bem ignorante mesmo, se ela pica ela não vai embora, ela volta e ela não perde o ferrão, ai ela pica de novo, como ela é bem valente você tem que tomar cuidado, eu conheço elas só de curioso mesmo, não dá mel nem nada, eu mexi só pra ver como é que ela fazia o ninho mesmo. Ela dá na árvore, as vezes aparece em outro pau, mas é mais em árvore mesmo e parece um tatu assim de costa né, é por isso que chama de taturã, quer dizer que parece o tatu mas não é tatu, é como se fosse o tatu, as costas do tatu, uma bola assim mais comprida que não é uma bola mesmo é comprida assim no pau da árvore, a picada dela dói mesmo, acho que ninguém toma só uma picada, dói muito".

5.4.3 Etnoespécie: Aguarakavy (idioma guarani, dialeto m’byá)

Descrição Declarada pelo informante

"Essa é uma grande fina e comprida, bem comprida, ela pica várias vezes, sem dó, ela é meia besta assim, é agitada e não tem discernimento, é brava toda vida. Pra saber mesmo a cor dela tem que olhar bem porque ela parece que é do amarelo pro preto, entre o amarelo e o preto assim, mais para o castanho com brilho, assim para o vermelho. O ninho dela é do tipo eixu, pode ser que dá no galho, ou até no cipó (yxypo), é uma bola que 
parece que é um tecido cobrindo o favo que ta lá dentro, mas não é como o tecido, é fino e bem forte, assim bem resistente e deixa dentro bem seco, a água não entra, é uma pele assim bem forte. Não dá mel e a cera não presta".

5.4.4 Etnoespécie: Kavy xi (idioma guarani, dialeto m’byá)

Descrição Declarada pelo informante

"Essa é bem fácil de reconhecer por causa que o ninho dela é bem cheio de espinhos, mesmo que você vê de longe, mesmo que não da pra ver a vespinha, dá pra ver que é ela por causa que o ninho dela é uma bola grande, tem um formato redondo e grande e cheio de espinhos que ela mesmo faz, é como se fosse um tecido bem grudado nos espinhos, é uma cor cinza, bem clara e parece que você olhando vai achar que é fininho, mas não é, é bem forte, bom é fino mas é como se fosse um tecido que não deixa entrar água e é bem forte, uma pele cinza de cor clara, mas bem cheio de espinhos. A kavy xi é uma vespa parecida com a eixu ela é rajadinha só que é pequena, é assim não muito pequena mas não é muito grande é quase de tamanho da eixu guaxu. A cor dela é quase verdinha, quer dizer não é vermelha nem preta, é que depende de como você olha para ela, parece que é meia verdinha, mas é que ela brilha no sol. Se caso ela não der na moradia da gente ai nem precisa mexer nela, é que se ela pegar ela pica de monte, ela nem escolhe não, é mais fácil dela ir assim igual besta né e pegar sem dó, se der em 
casa tem que tirar logo porque se ficar muito grande ai você vai ter muito trabalho para tirar ela e ela pica mesmo. Essa eu nunca ouvi dizer que desse mel, acho que não dá é nada mesmo".

5.4.5 Etnoespécie: Eixu guaxu (idioma guarani, dialeto m’byá)

Descrição Declarada pelo informante

"Essa vespa tem uma barriguinha de outra cor, ela é pequena acho que do tamanho da ei raviju, acho que é um pouco só mais pequena e mais fininha que ela. Essa vespa é diferente das outras por causa que ela faz mel, mas o mel delas é bem diferente do mel das abelhas de verdade mesmo, parece que é uma pasta que está guardado dentro dos favos dela, para você tirar o mel nem dá certo, tem que mastigar tudo junto, o mel é como se estivesse açucarado, assim duro pastoso mesmo e como o favo do mel é bem fininho nem dá para separar, ai se faz comer com o favo mesmo, ou você engole ou você cospe, acho que vai tudo junto. O ninho delas parece uma bola, tem uma espécie de capa envolta de tudo e é como se fosse um tecido que não molha e nem derrete no sol, fica ali dias chovendo e não molha mesmo, é cinza, é fininho e muito forte, olhando assim até parece que é de cera mas não é, é feito como o tecido mesmo. Ela costuma fazer o ninho dela no chão, encima da terra, geralmente no capinzal, parece até um formigueiro, acho que tem mais ou menos quarenta ou cinqüenta centímetros de altura do chão, é por isso que a gente chama de eixu guaxu por ser 
grande e no chão, assim meio redondão mesmo. Quando ia tirar o mel tinha que tomar muito cuidado para não tomar picada de monte né, tem que pegar uma vara comprida e ir cutucando e com um gancho vai desmanchando tudo para poder pegar de longe para não tomar picada, dói muito e a casa delas tem muitas vespas se te pegam é doído de mais. O melhor mês para pegar e retirar o mel delas é em dezembro, sempre está cheio de mel, está carregado de mel dentro da casa delas. 0 mel deve ser comido, acho que não é bom para fazer nada além de comer, e como ele vem como se fosse uma pasta nem dá pra tirar a cera então é comer mesmo".

O informante explicou que os brancos costumam chamar todas as vespas (kavy) pelo mesmo nome, de "marimbondo" ou mesmo de "vespas". Por outro lado em conversas informais, explicou que não sabia qual o nome usado pelos brancos para as diversas vespas, pois: "não era muito comum se dar importância para isso". Porém, em diversas ocasiões durante as conversas informais, Karai Poty ao se referir aos ninhos de eixu guaxu explicou que os brancos (paranaenses), chamam de lexiguano os seus ninhos, bem como, ao se referirem às próprias vespas, costumam chamá-las também de lexiguano.

A palavra eixu, segundo Ferreira (1986), é uma variação de eixuĩ (do tupi ei'xu + $\tilde{I}=$ pequeno), que também é uma variação de ei'xu, que o autor apresenta com a seguinte tradução: "a casa ou colméia da vespa eixuĩ". Tais palavras foram "abrasileiradas", e também são pronunciadas no sul do Brasil, até o presente, como enxu ou exu. Verificando a tradução oferecida por Dooley (1982), pode-se constatar que para o vocábulo eixu, a tradução é "pexiguano" (indicado como sendo "ninho de vespas"), que Ferreia (op. cit.), comenta como sendo um vespídeo, o qual tem como variações: eixu, enxu, exu e sinônimos: lechiguana, lichiguana, lecheguana. 
Com base na descrição declarada para as etnoespécies de vespídeos, mesmo oferecendo pistas taxonômicas básicas, por não se tratar de um estudo voltado para esse grupo de animais, não serão apresentadas as possíveis denominações científicas para esta categoria.

\subsubsection{Utilização dos produtos das vespas}

Quanto ao uso dos produtos das vespas, o informante explicou que a única vespa produtora de mel é a exui guaxu. Para as outras quatro etnoespécies citadas nesta categoria a informação é que elas não produzem mel, e a produção de cera é insuficiente para uma extração compensatória. Enfim, sobre as etnoespécies que não produzem mel, Karai Poty explicou que não conhece qualquer utilidade para os produtos por elas fabricados. Também desconhece qualquer pessoa que tenha tentado manter as etnoespécies de kavy em caixas, ou mesmo, as tenha mantido como sendo de sua propriedade em ninhos espalhados na área da aldeia ou em seu entorno.

Segundo sua declaração, o consumo do mel das vespas eixu guaxu se dá mastigando o próprio favo onde ele está depositado. A justificativa citada para essa ação é o fato do mel ser pastoso e de difícil retirada dos alvéolos.

O ninho dessas vespas é redondo e sua arquitetura interna é formada por camadas concêntricas. A retirada do produto oferece certa dificuldade, por se tratar de uma cera fina. Baseando-se nessas afirmativas considera-se que são fatores indicativos de que o consumo não se dá apenas sobre o mel mas, certamente, parte da cera que o envolve e também os depósitos de pólen são consumidos, uma vez que em outros casos, no caso das abelhas, os potes de pólen e favos contendo larvas, eram consumidos junto com os depósitos de mel.

O uso do mel das vespas eixu guaxu é discutido na literatura e pode provocar algumas controvérsias. Confrontando os dados fornecidos pelo informante Karai Poty com as informações de Nogueira-Neto (1997), chama a atenção o fato da existência de relatos a respeito de intoxicações causadas 
pelo mel de "lecheguana". Saint-Hilaire ${ }^{53}$, citado por Nogueira-Neto (1997), apresenta uma passagem em que o naturalista, no oeste do Rio Grande do Sul, se intoxicou com mel de "lecheguana". Após a ingestão do produto desse inseto, ele e outros de sua expedição apresentaram "o sintoma de delírios e bebedeiras". No entanto, no dia seguinte, continuando seu trajeto, a expedição encontrou "uma casa de marimbondos 'absolutamente semelhante' e pertencentes também a 'lecheguana'”. Alguns índios de sua comitiva comeram o mel e nada sentiram.

Existem muitos relatos ${ }^{54}$ de cronistas e viajantes a respeito de intoxicações causadas pelo consumo de mel considerado tóxico. O antropólogo Vellard, discute pormenorizadamente em seu livro "Une civilization du mel" a convivência de uma tribo indígena do Paraguai (os Guaiaqui), com as abelhas e vespas. Segundo esse autor, os Guaiaqui consideravam embriagante o mel de algumas espécies de abelhas e vespas, principalmente das vespas "lecheguana", podendo até levar à morte de quem consumir o produto (Vellard, 1939).

No entanto, as observações a respeito de méis tóxicos referem-se não apenas ao mel, mas também a outros produtos das abelhas e vespas (pólen, cera, cerume, própolis, geoprópolis), sempre com a observação de que a possível causa pode estar nos polens de algumas espécies de plantas e, em determinadas épocas do ano (Nogueira-Neto, 1997). Outras observações são necessárias para que se possa atribuir toxidade ao mel ou a outros produtos das abelhas, ou talvez aos produtos tóxicos que são retirados das plantas. Segundo Miller (1997), deve-se levar em consideração que muitas espécies de insetos seqüestram toxinas de plantas que são produzidas pelas próprias

53 SAINT-HILAIRE, A. Relation d'um empoisonnement cause par lê miel de la guepe lecheguana. Ann. Sc. Nat. v.4, p.340-344, 1824.

54 Uma referência mais detalhada a respeitos dos apontamentos e trabalhos desenvolvidos a respeito de intoxicações causadas pelos produtos de vespídeos e algumas abelhas, podem ser encontrada em Nogueira-Neto, (1997). Alguns trabalhos consultados para esta dissertação, apresentam dados interessantes sobre o conhecimento que os índios do território brasileiro, paraguaio e uruguaio tinham a esse respeito, para maiores detalhes consultar: Azara ([1806] 1847); Bruening (1990); Faria \& Lamartine (1964); Holmberg (1887); Howes (1945); Ihering ([1903] (1930), Ihering, R. (1940); Ott (1998); Reaumur (1740); Saint-Hilaire (1824 e [1847] 1944); Sanches-Labrador (1776); Schwarz (1948); Spix \& Martius (1938). 
plantas e que são inadequadas para o consumo humano, ou mesmo, por um grande número de espécies de outros animais.

Os insetos tóxicos podem ser subordinados a uma classificação que os divide em dois diferentes grupos: criptotóxicos e fanerotóxicos (Blum, 1994). As abelhas e vespas (ordem Hymenoptera), estão incluídas no grupo dos insetos fenerotóxicos, ou seja, que são peçonhentos, mais especificamente os insetos que apresentam um aparelho de peçonha que incluem uma glândula, um reservatório, um ducto e um aparelho para injetar a peçonha. As abelhas e vespas, cujas secreções são distribuídas tanto por ferrões retráteis como por peças bucais penetrantes, produzem efeitos toxológicos ativos através de injeção, podendo ser inativos através da ingestão; mesmo assim, o autor recomenda cautela sobre o uso desses insetos para a alimentação.

A toxidade do mel foi assunto em uma conversa com o informante Karai Poty, que assegurou que tal situação é possível, principalmente quando as abelhas retiram o pólen de determinadas plantas. Citou o caso das abelhas que visitam "o pé de fumo" (ver a descrição da abelha ei irapua), no entanto em nenhum momento deu muita importância ao fato, nem mesmo mencionou os sintomas de intoxicação para qualquer situação de consumo do mel. Porém quando Ihe foi perguntado especificamente sobre essa questão, respondeu que:

“(...) há você tem que experimentar um pouquinho de um mel que você tem dúvida se é bom ou não, se você experimentar só um pouquinho pode ser que já fica sabendo se ele é bom ou não, se der uma reação ai não deve comer e pronto, é lógico que se der alguma reação assim de se sentir mau, ai você nem deve mais comer, não vai comer uma colherada né, ai é arriscar de mais, come só um pouquinho e se tiver que mexer com o organismo da gente, é certo que já vai se saber ali mesmo". 
Aparentemente existe uma preocupação com relação ao que pode acontecer quando se consome um mel desconhecido, isto é, em que existam dúvidas a respeito de como a abelha ou a vespa o produziu. Mas, ficou claro que também existe um controle sobre esse consumo e que não devem ter ocorrido experiências negativas memoráveis, caso contrário seriam lembradas após a condução indutiva para a questão.

Pode-se aduzir que por se tratar de um vespídeo que sabidamente é agressivo, crianças e pessoas menos experientes devem manter um distanciamento maior dos ninhos encontrados ao acaso. A situação de retirada de mel de abelhas e vespas agressivas deve ocorrer com a "supervisão de um especialista". Alguns índios, na Aldeia Morro da Saudade, mesmo conhecendo as abelhas, isto é, distinguindo seus nomes e características gerais, informaram que nunca retiraram mel ou qualquer produto em colméias naturais e nunca se habilitaram a mexer em uma caixa ou colméia levada no próprio tronco para a aldeia. Embora sejam consumidores de mel, de uma forma geral, consideram poucos índios "preparados para mexer nas abelhas", sempre indicando alguém em especial, melhor preparado para essa atividade.

Tais afirmativas são indicativo de que as atividades discutidas a respeito das questões relativas ao manuseio das abelhas "devem" sempre ser desenvolvidas por pessoas comprovadamente conhecedoras dessa prática, podendo-se reconhecer para tais pessoas a designação de especialistas.

Foi apresentado um esquema de abelha sem ferrão ${ }^{55}$ aos principais informantes com intuito de que eles pudessem identificar as diversas partes que compõe o corpo de uma abelha, apontando para a parte e declarando a denominação em seu próprio idioma. Os resultados estão descritos na Figura 9, a seguir:

55 Adaptado de Camargo \& Posey, 1990. 


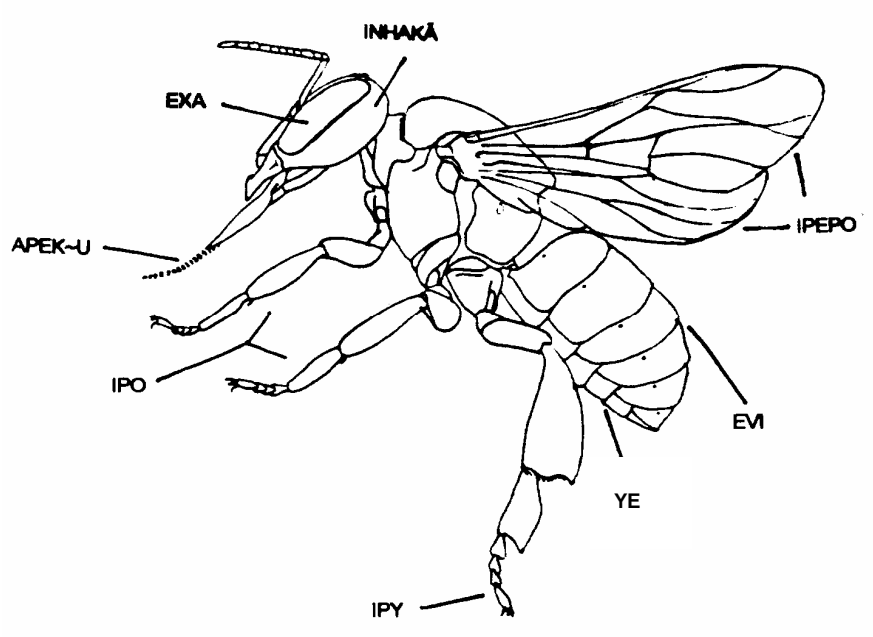

Figura 9 - Esquema de abelha sem ferrão apresentada ao informante (a denominação foi declarada após ser apontada a parte referida) 


\section{CONCLUSÕES}

O primeiro parágrafo de uma análise conclusiva sobre o estudo do conhecimento de uma etnia tão rica e diversificada quanto os Guarani-M'byá, deve ser a de que este é um estudo preliminar e que apenas inicia o entendimento que a ciência pode ter a respeito do objeto estudado. Esse é, sem dúvida, o mínimo que se pode fazer como reconhecimento de um conhecimento sobre o qual pouco se sabe.

Atendendo aos objetivos iniciais propostos para este estudo, a análise dos dados apresentados indica que o conhecimento dos Guarani-M'byá sobre as abelhas sem ferrão, remonta a muitas gerações passadas. Esse conhecimento etnoentomológico é coerente com o conhecimento científico e poderá contribuir para a re-introdução de espécies polinizadoras nas regiões de Mata Atlântica onde os Guarani vivem, exercendo a função de auxiliar na recomposição da biodiversidade, bastante ameaçada na região da área onde se desenvolveu este estudo.

A importância das abelhas e vespas no modo de vida dos índios Guarani apresenta-se com significativa participação, mesmo nos dias de hoje em que na localidade onde se desenvolveu o presente estudo não foram localizados ninhos na natureza ou acondicionados em caixas de criação.

No pensamento dos Guarani M'byá e em sua explicação de vida de uma maneira geral, isto é, quando os índios se referem ao seu modo de ver o mundo em que vivem e em que vivem as outras formas de vida como os animais, estão incluídos os insetos como as abelhas e vespas, a vegetação, os antepassados e os criadores do mundo, os espíritos e entidades divinizadas. 
O conhecimento sobre as abelhas e algumas vespas entre os Guarani da aldeia Morro da Saudade pôde ser notado em, praticamente, todos os moradores e visitantes do local. O que difere na comunidade, no entanto, é o grau de profundidade de conhecimento disseminado entre as pessoas. De maneira geral todas as pessoas reconhecem a existência das abelhas e sabem, que são elas que fabricam o mel e a cera, ente outros produtos e que as velas usadas em cerimônias e rituais, muitas vezes, são elaboradas com cera das abelhas, além de saberem que elas visitam diversas flores de diversas espécies de vegetais. Porém, alguns membros da comunidade são apontados como grandes conhecedores do assunto.

Tratando-se da metodologia etnobiológica a analogia conclusiva confirmou, positivamente, o teste da hipótese de existência de especialistas no assunto "abelhas sem ferrão", que a comunidade indica como grandes conhecedores de abelhas e, que foram selecionados como os principais informantes ou informantes-chave.

O conhecimento desses informantes a respeito do assunto foi, sem dúvida construído, principalmente, a partir de ensinamentos transmitidos oralmente entre as gerações, baseados no aprendizado dos mais jovens que seguiam e aprimoravam o que aprendiam de seus pais, tios e avós. Porém, é importante afirmar que a observação que o aprendiz realizava, sobre a prática que estava sendo desenvolvida durante a transmissão do conhecimento, o integrava naquele assunto e, ao reproduzir tais práticas testava seu conhecimento, inclusive adequando-o às suas necessidades.

As informações revelaram o conhecimento de 25 etnoespécies, identificadas como pertencentes a 03 diferentes categorias. Sendo que 13 etnoespécies foram agrupadas na categoria das abelhas sem ferrão, 07 etnoespécies à categoria de abelhas com ferrão e 05 etnoespécies à categoria de vespas. Tais dados, quando relacionados com os dados científicos (cognição comparada), apresentam similaridade e equivalência. 
Para essas etnoespécies as informações abrangeram: descrição, distribuição, nidificação, sazonalidade, dispersão, aspectos biológicos, do hábitat, ecológicos, fenológicos, detalhes morfológicos e etológicos, manejo e práticas de manipulação para extração de produtos, acondicionamento e semidomesticação, destacando-se uma riqueza em detalhes para a categoria das abelhas sem ferrão.

O uso de produtos dessas abelhas, tais como mel, cera, cerume, própolis, geoprópolis, pólen e as próprias abelhas em estado larval e em outros estágios de desenvolvimento, foram apontados para vários fins como alimentação, preparo de poções destinadas ao uso da medicina tradicional e atividades que se referem à vida espiritual e contemplativa, bem como para o artesanato.

Constatou-se que em seu caráter essencial de utilização, o mel foi considerado o produto mais importante dentre todos, tendo mérito $\mathrm{e}$ funcionalidade de desempenhar o papel de alimento e item das receitas da medicina tradicional.

Detalhes sobre as etnoespécies foram apresentados pelos informantes-chave, a partir da formulação de explicações compostas por dados que se complementavam na interdisciplinaridade envolvendo diversos conceitos que, aos olhos das etnociências, são manifestações de um saber acumulado, modificado constantemente e que se adaptou à realidade de cada geração, bem como, de cada indivíduo, podendo ser visto como equivalente ao conhecimento científico em vários itens, como por exemplo: ecologia da espécie, nicho, manejo para equilíbrio da biodiversidade, inter-relação entre espécies de diferentes reinos.

A (re)transmissão do conhecimento a respeito das abelhas ocorre diretamente na transmissão que interpretava o equilíbrio entre os homens (os Guarani), a natureza (a mata, o sol, a lua, as águas, os animais, o calor e o frio), enfim: sobre a ecologia e o ambiente, o equilíbrio e uso de recursos naturais e, principalmente, na prática diária de diferentes atividades. Embora, 
entre os Guarani M'byá, o conhecimento seja transmitido tradicionalmente pela oralidade, de geração para geração, principalmente de pai para filho, esse processo tem sido menos constante, no que diz respeito aos ensinamentos sobre as abelhas sem ferrão e insetos correlatos.

Os filhos dos principais informantes revelam um conhecimento comum sobre o assunto, isto é, tal conhecimento não pode ser diferenciado, de uma maneira geral, do senso comum, notório entre a maioria dos membros da comunidade.

Além disso, os mais jovens e crianças em geral, desconhecem o assunto, apenas ouviram falar da existência desses insetos pelo professor de educação formal da escola indígena instalada na aldeia, ou então aprenderam a escrever a palavra abelha e a palavra mel em seu próprio dialeto, nas aulas de escrita de idioma guarani-m'byá que são ministradas por professores indígenas, filhos da própria aldeia.

Os motivos alegados para que esse conhecimento não esteja sendo transmitido atualmente é a falta de tempo e o excesso de outras atividades a que estão submetidos os índios: o principal informante é representante do Conselho Distrital de Saúde das Áreas Guarani de São Paulo, (Morro da Saudade, Krukutu e Jaraguá), cuja sede é em Curitiba - Pr -. Embora sua moradia continue sendo na aldeia Morro da Saudade; as reuniões que deve participar por ocupar a representação na área da saúde, se dão no Paraná, onde passa grande parte do tempo. Além disso, ele já realizou viagens para a Europa e, freqüentemente é convidado por autoridades de diversas competências dos governos municipal, estadual e federal, entidades filantrópicas, não-governamentais, estudantes e pesquisadores, além dos religiosos de diversas correntes do cristianismo, para participar de reuniões e eventos fora da aldeia.

O informante-chave, que é um especialista em abelhas sem ferrão, é uma liderança local reconhecida inclusive por líderes de outras aldeias. Foi cacique da Aldeia Morro da Saudade por longo período e muitas vezes, até 
hoje, em assuntos internos, é consultado pela FUNAI. Sua esposa tem um emprego no posto de saúde (postinho) dentro da aldeia, 08 horas por dia, o filho mais velho tem um emprego de professor indígena e cursa o segundo grau em uma escola formal num bairro vizinho ao aldeamento. Enfim, outras prioridades ocupam momentaneamente o tempo e espaço na vida da aldeia.

Por outro lado não se pode afirmar que esse conhecimento esteja sendo perdido. O atual cacique da aldeia, o jovem Timóteo, em certa ocasião, solicitou a este pesquisador que, the fosse apresentado um projeto de reintrodução de espécies de abelhas nativas para aquela aldeia, para que os costumes pudessem ser revividos e para que se retirasse mel de abelhas como a jatei para comercialização. Vários índios procuraram este pesquisador para solicitar caixas para criarem abelhas Apis mellifera e também chegaram a solicitar que thes fosse fornecidos enxames dessa espécie para que os mantivessem sob responsabilidade da família. A principal justificativa, neste caso, foi de que o mel poderia ser comercializado Geraldo um ganho financeiro para a família.

Durante os trabalhos de pesquisa, ocorreu uma reunião entre os caciques de mais de vinte aldeias, na qual este pesquisador foi convidado a participar, e que solicitaram que thes apresentasse um projeto para a implantação de um meliponário (abelhas sem ferrão: meliponinae) e um apiário (abelha com ferrão: Apis mellifera). A idéia era também de re-introduzir a prática de manipulação das abelhas e o aproveitamento de seus produtos em seus costumes e, principalmente, o fornecimento de mel para venda no comércio em geral e o esforço reverter em benefícios financeiros para as aldeias.

Em conversas informais ocorridas entre este pesquisador e membros da FUNAI (Administração Regional de Bauru, SP), na aldeia Morro da Saudade, em 2003, houve um convite para que se examinasse a possibilidade da elaboração de um projeto sobre a criação de abelhas nativas não apenas naquela aldeia, mas, para várias aldeias de São Paulo, incluindo-se as do litoral. Constatou-se, na ocasião que 
vários líderes e caciques já haviam se referido ao mesmo assunto e que existia interesse das comunidades indígenas em voltarem a ter abelhas nativas. Na semana de 23 a 28 de Agosto/2004 houve um comunicado de um funcionário da FUNAI, sobre a ida de técnicos de Brasília para ministrar um "curso sobre a criação de abelhas nativas" em uma aldeia do litoral, a pedido dos próprios índios. Desse curso, participariam índios de várias aldeias, inclusive Morro da Saudade, Krucutu, Aguapeú. 


\section{ANEXOS}


ANEXO A - Depoimento de NIVALDO ${ }^{56}$, cacique da Aldeia Morro da Saudade, Barragem (01/02/1984), sobre a história da migração da sua família para São Paulo.

Obs: O presente depoimento foi transcrito em sua íntegra do livro: Índios no Estado de São Paulo: Resistência e Transfiguração. Capítulo: Aldeias Livres Guarani do Litoral de São Paulo e da Periferia da Capital. Paginas 134-141. O depoimento foi colhido por Maria Inês Ladeira, autora do capítulo, em 1984.

"Antigamente, quando eu estava no Paraná, eu não sabia como a gente vivia lá, porque lá vivi no tempo de criança.

Não tinha escola antigamente. Já tinha Posto da FUNAI, mas eu não estudei porque não tinha escola lá. Mas eu trabalhava na lavoura. Mas naquele tempo com 15 anos, quando eu trabalhei, era 50 mil réis, 50 cruzeiros e o adulto ganhava o mesmo.

Não aprendi a falar como o branco. Até 17 anos. Trabalhar eu trabalhava. Quando o patrão mandava eu fazia, só que falar eu não falava.

E vai indo, vai indo até que um pouco aprendi.

E naquele tempo, a criança não usava roupa. Meu pai não comprava, não tinha calça, não tinha nada. Antigamente era só aquele paninho de pôr nas costas, amarradinho, como camisa. Acha um paninho e põe, não tem costura nada.

Até 20 anos eu fiquei em Palmeirinha, trabalhando na lavoura. Ai eu conheci o Posto, mas não tinha nada.

Quando tem doença os índios morrem, morem. Nós usávamos o remédio da natureza, mas acabavam morrendo os velhinhos, as crianças. E não tinha remédio de branco no Posto, nada.

\footnotetext{
${ }^{56}$ Nivaldo é originário da aldeia Palmeirinha, Posto Indígena Mangueirinha, PR. Sua família liderada por sua avó, fundou a aldeia da Barragem, atualmente a mais numerosa de São Paulo.
} 
E nós vivíamos com os Kaigang. E naquele tempo não tinha muito branco como agora, até que eu tinha 20 anos não tinha estrada, aquela estrada lá dentro da aldeia.

E eu fui crescendo. Conhecia o avô, a avó do meu pai, que morreram só da idade. $\mathrm{E}$ hoje em dia quase não tem velhinho, só gente nova. Naquele tempo existia velhinho que até nem andava mais. Tinha que o neto, a neta pegar pelo braço para andar por aí.

Depois que nós viemos para São Paulo, eu aprendi mais falar como branco, assim. Não aprendi tudo. Tem lugar que o branco fala e eu não estou sabendo também. Agora, de hoje pra diante, as crianças que nós temos vão aprendendo mais rápido. Eu não aprendi a escrever na aldeia. Hoje em dia mudaram a vida dos índios. Até o alimento já esqueceram.

Naquele tempo, em Palmerinha, nasci lá mesmo, banha de porco, óleo não usava. A pessoa que fazia a comida, fazia sem banha, só um pouquinho de sal. Tinha gente que não comia sal. Mas trabalha. Planta feijão, milho, mandioca, batata, melancia, pepino. E criava bastante galinha, que nem o Jejocó lá no Silveira. Mas cada um, cada família morava longe da outra, distante de dois quilômetros. Mas tinha muitas famílias.

As mulheres cozinhavam. Tem ano que planta arroz então come, se não come quirela com feijão e batata, assim. Agora, hoje em dia, nossa família que cresce não conhece esse alimento, tem hora que não quer quirela com feijão. Naquele tempo caça no mato tinha bastante, e matava mesmo. Porque o branco não entrava para caçar. Só pouco. Agora é difícil de achar a caça do mato porque já tem muita batida dos brancos e a mata não é muito grande mais.

Eu vivia no mato mesmo, e a caça pegava na armadilha. E, naquele tempo, não conhecia macarrão. $\mathrm{E}$ o trigo comprava pouco, mas não usava como hoje. $\mathrm{E}$ café não usava, só o mate de erva. E açúcar não usava, só mel do mato. Naquele tempo quando nós andava só no mato, procurava o mel e furava e trazia, e aquilo que era o 
açúcar. E palmeito alimento dos índios, comia com mel, Hoje a criançada nem sabe que era o alimento. E muito milho.

Eu sai de Palmeirinha por causa do Posto. Naquele tempo o primeiro chefe que conheci, o Atílio. O primeiro chefe do índio ${ }^{57}$ que existiu lá. Então quando conheci, ele já estava mandando os índios fazerem o serviço, a troco de quirela mesmo. Então duas Kaigang ficaram de cozinheira, e quarenta, cinqüenta pessoas, trabalhavam no Posto, só homens. Às vezes trabalhávamos 20 dias. Até que o chefe mudou e o trabalho ficou o mesmo: faz isso, faz isso, faz isso. Obrigado fazer. Então, se não fazia por preguiça já vinha a polícia em cima da gente. Então tinha que ficar amarrado e depois levavam e ficava na cadeia, dois, três dias. Depois tinha que tocar o serviço.E trabalhar sem ganha também, trabalhar na roça. E alimento só quirela e fubá e polenta. Todos os dias, um mês, quinze dias, até enjoava comer só aquilo. Tinha hora que ia o feijão. Agora se a gente reclamava, tinha que ficar na cadeia. Até que o Vítor entrou de chefe e nós resolvemos pensar em sair de lá. Ele mandou fazer roça de novo. Setenta alqueires mandou roçar, Aí trabalhamos, até 15 dias. Nós trabalhamos 15 dias e depois nós fugimos de noite. Porque não agüentava mais fazer isso. Fugimos por causa do chefe. Uma turma. Cinco, seis famílias, todos parentes. Minha ave era mais moça, morreu aqui. Meu avô já era morto faz tempo. Ela veio com a gente, Aí nós viemos. Famílias, todos parentes.

A primeira viagem que nós fizemos para chegar em São Paulo, nós fizemos em três meses. A pé. $O$ chefe do Posto não veio atrás de ninguém, porque não adianta procurar os índios que fogem. Fugiu, pronto, veio embora.

Viemos a pé, chegava a noite, nós dormíamos na beira da estrada. A gente vinha vindo, até chegar em São Paulo. Na viagem tinha mais ou menos quinze pessoas: crianças, adultos. A primeira vez que nós saímos de lá nós fomos ate Itariri.

Em São Vicente o Higino do Xapé falou que lá tinha aldeia, que era bom, que dava pra viver.

\footnotetext{
${ }^{57}$ Quando se refere ao chefe, é ao chefe do Posto indígena da FUNAI.
} 
Nós tiramos passagem do Buri no Paraná, então deram passagem até São Vicente.

Não sabíamos que tinha aldeia porque a gente não conhecia o lugar. Conversamos com o Higino em São Vicente, porque ele é índio Guarani também. Aí, lá de São Vicente, o Higino conversou com o delegado. Aí então ele arrumou um carro de trem pra levar a gente até Itariri. Chegamos, encontramos o Antonio Branco ${ }^{58}$. Também lá tinha pouca gente, a mesma coisa que agora.

Ficamos três meses, mas nós sofremos. Porque nós tirávamos palmito, fizemos trabalho e vendemos. Antonio Branco já não queria já não queria dar de graça o cacho de banana. Tinha que comprar ou senão não come banana verde. Ele estava vendendo. $\mathrm{E}$ ainda mais, nós éramos bastante. Crianças também bastante. Então resolvemos sair de lá. Agora, se a pessoa contava que queria sair de lá, ele não deixava sair também, o Branco. Então, uma vez o pai falou que ia mudar para Silveira. Então nós já estávamos até na cidade de Itariri. Quando nós chegamos lá, ficamos esperando trem que ia pra Santos. E Antonio Branco chegou na delegacia, já conversou com o delegado para prender a gente, então ele prendeu. $E$ os homens ficaram todos na cadeia em Itariri. E as mulheres eles levaram de volta para a Aldeia, de noite. E ficamos lá uma semana de cadeia, na delegacia. Aí o marido da Tereca lá do Silveira, que ta vivendo com o Jecocó agora, que chamava João também e morava em Itariri. Ele fez força para os parentes saírem da cadeia.

Então ele conversou com o delegado: Por que motivo que meus parentes estão sofrendo aqui? Então você pode soltar porque eles não estavam matando ninguém. Os índios aqui são novos. É que não acharam bom o lugar e eles estão querendo sair, por isso que ele (o Antonio Branco) botou eles na cadeia, mas não pode fazer isso.

E depois de dez minutos já mandaram sair tudo. Com todo foi seis dias. Porque, ele o João, não estava sabendo que nós estávamos na cadeia, porque não contaram também. E saíram todos e voltaram a te Itariri na aldeia. Até três dias. E, a

\footnotetext{
${ }^{58}$ Antonio Branco ainda hoje é cacique da aldeia Itariri.
} 
noite, nós resolvemos fugir. Tinha que fugir mesmo, porque não dava. Aí, a noite, nós fugimos de lá da aldeia e nós fomos até na Raposo Tavares. De lá que nós pegamos o trem até Mongaguá. Em Mongaguá nós chegamos seis e meia da manhã. Nós descemos lá e achamos a estrada que vai pro Rio Branco, a sorocabana. E nós chegamos lá e quando nós chegamos lá, o capitão era bom. Era o falecido Francisco. E nós sabíamos que tinha aldeia lá, porque já contaram o pessoal de Itariri. Quando eu estava no Paraná são sabia. Quando nós viemos pra cá, já nós soubemos onde que tinha Guarani onde não tinha mais. Quando nós viemos não sabíamos para onde ir. Então nós fomos para Itariri, depois viemos pro Rio Branco, depois nós passamos no Silveira.

E nós chegamos no Rio Branco, em dois dias. E chegamos lá, e quando cheguei lá tudo era bom, porque na hora não se vê muita coisa também. Naquele tempo tinha bastante gente, e tinha muito mosquito também. Nem tanto como agora, mas daquilo (dos mosquitos) nós estávamos reclamando também. Aí nós fomos até o Silveira.

Do Silveira contaram lá do Rio Branco. Apessoa disse que primeiro morava no Rio Branco e depois mudaram para lá. E quando nós chegamos no Silveira estava o falecido Gumercindo. Ele também era bom, quando não bebia era cacique bom também. Quando bebia, ele mudava a vida. E brigava, mas eu não ligava. Até que nós agüentamos três meses também. Depois de três meses já fomos.E tinha mesmo gente no Silveira. Dali de Ubatuba era tudo do Silveria, naquele tempo. E no fim nós saímos pra Serrinha. Naquele tempo, morava o Inácio que morreu em Mongaguá. E nós fomos todos, e o Inácio falou: - Se você quiser ficar, fica à vontade.

E vai indo assim e ficamos mais um mês. E aí mandaram a gente embora dizendo que nós éramos ruins que saímos de lá do Paraná porque nós estávamos devendo, porque nós matamos no Paraná. É conversa. Então as pessoas não queriam deixar lugar para nós. Quando nós chegamos numa aldeia já tinham falado que a gente devia, que nós matamos, é conversa.

Aí nós falamos que se nós tivéssemos matado um cara, como viajaríamos com família, crianças? É porque não devia, senão não viajaria com família. 
E assim, quando nós chegamos em Itariri, já tinham falado. No Rio Branco, játinham falado assim. Nós chegamos no Silveira, já tinham falado assim. Dizem que nós somos muito valentes, não sei. Aí as pessoas tinham medo, não queriam que nós ficássemos ali. Aí nós fomos pra Serrinha, e depois nós saímos e voltamos.

Em Bertioga nós ficamos três semanas na cidade. E depois nós saímos de lá. Em São Vicente nós ficamos um mês, só assim, atrapalhados, porque nós não sabíamos aonde ir agora. Porque nós conhecemos todos os lugares e o Cacique que não quer.

Aí n's viemos assim. De São Vicente nós viemos pra São Paulo e primeiro nós fizemos assim, e depois nós voltamos para o Paraná de novo. E depois, quando nós chegamos no Paraná, já tinha o chefe do Posto não deixava mais ficar, não tinha lugar mais pra ficar. Então nós ficamos só um mês em Palmeirinha, depois nós voltamos. E assim, assim nós chegamos até São Paulo. Naquele tempo estava o Joaquim aqui na Dutra. E eu conheci ele na cidade. Encontrei na rua e aí ele era índio também e prometeu levar na casa dele, e aí que fomos parar lá. E ficamos, ficamos assim, e depois nós descemos pro Rio Branco também, segunda viagem. Depois voltamos, assim, e viemos aqui na Ponte do Socorro. Saímos do Rio Branco por causa do mosquito mesmo. No Paraná tinha, mas não igual, só pouco. Tinha dias que tinha bastante, tinha outro que não tinha. E nós ficamos na ponte do Socorro, acho que três meses. Aí que o japonês foi lá, chegou lá conversou com as pessoas. Eu não acreditei também porque tem muita gente que engana também. O Sessé (o japonês) chegou lá e falou que tinha lugar pra morar, trabalhar, E na primeira conversa ninguém falou pra vir aqui. E voltaram depois de quatro semanas. Depois de outra semana eles chegaram de novo. Aí falaram. Aí que o pai falou para mim: - Acho que é bom de ver o lugar, de ver como está isso aí. Se é verdade mesmo da pra ir morar.

Mas não tinha ninguém. Aí ele voltou de novo. Depois de uma semana ele foi de novo, aí que ele já trouxe as pessoas. Aí que eu falei pro meu pai: Agora você tem que mandar duas pessoas, uns homens, lá pra ver o lugar. Pra ver se a gente gosta. Aí veio o Calixto e mais um com o Sessé. E ficaram uma semana. Pescaram peixe mataram ganbá. Naquele tempo, ninguém mexia nesse matinho também. 
Caçaram tatu, e depois que eles voltaram. Aí que o Calixto falou: Acho que o lugar é bom. O japonês dando a terra mesmo, acho que é bom. Ai que eu resolvi. Eu fiquei alegre porque agora o japonês vai dar a terra mesmo. Aí eu falei: Vamos embora. $O$ japonês foi também, junto com as pessoas. Carregamos panela, saco velho, nós viemos de trem. Naquele tempo tinha dois trens. De manhã vinha pra cá, ia outro pra lá. Aí nós viemos todos para aqui. Viemos e ficamos, ficamos.E nessa parte tudo ali era mata, boa mesmo, e capoeiras.

E ele comprava alimento, até um ano. Cada mês comprava feijão, arroz, trigo, banana. Depois que o Sessé resolveu fazer lavoura. O Xapé ${ }^{59}$ eu já conhecia aqui em São Paulo. De primeiro morava ele com a filha, o filho. Antes, diz que o Xapé estava aqui. E depois Sessé falou: Eu queria fazer lavoura de mandioquinha, pra mim. E queria que vocês me ajudassem a plantar mandioquinha, pra vender pra mim.

Só aquilo que ele queria. E nós ajudamos a fazer isso. Aí depois de dois anos ele falou: Agora não preciso mais. Não preciso mais pra mim porque agora vocês já estão pagando a terra. Vocês ficam morando, plantem alguma coisa que vocês quiserem que eu não estou ligando. Ele ficou um ano com nós aqui. Vendeu mandioquinha e o reto que sobrou, ai ficou pra nós. O que ele encaixou, ele vendeu tudo. O resto, o miúdo, os índios comeram. E depois ele falou: Agora eu vou viajar para o Japão. Vou passear, vou ficar um ano por ai. Aí que ele deu aquele papel que eu tinha aqui. Aí ele saiu daqui e dentro de um mês um cara chegou de lá de Santo Amaro. Eu nem conhecia o cara também. Ele queria mexer com essa terra.

E chegaram numa pick-up. Ele e a mulher. Aí ele falou pra mim: E quem mandou você vir morar aqui? Aí eu falei: O japonês que falou pra gente vir morar aqui, então nós viemos.

- O japonês é ladrão. A terra é minha, essa, casa, é tudo meu. Então pra vocês não perderem essa terra, uma parte eu vou dar, aqui embaixo na represa. Nessa berada aqui da represa eu vou dar.

\footnotetext{
${ }^{59}$ Xapé é cacique da aldeia do Bananal (Posto Indígena de Peruíbe), há um ano, juntamente com sua família foram os primeiros habitantes Guarani da atual aldeia da Barragem.
} 
Um alqueire só. Para todas as famílias morarem. Aí eu fiquei pensando. Nem mostrei aquele papel. Eu fiquei quieto. Tinha essa máquina velha aí (máquina de costura). Eu arrumava as coisas aí, nem falei. Fiquei arrumando a máquina velha e daqui a pouco saiu o cara. Foi embora. No outro dia voltaram de novo. Aí ele trouxe um serrote para serrar madeira. Aí ele falou: Ei, vocês não estão mudando essas casas aí, vocês podiam desmanchar essas casas daí porque nós demos pra vocês fazem a casa ali e morar lá embaixo. Vão morar lá. Esse pedaço aqui, essa parte é minha. Vou mandar arar, fazer lavoura. Fiquei esperando, só. Não falei.

- E o japonês é ladrão mesmo. Ladrão de terra. Se eu tivesse encontrado o japonês, eu matava esse japonês.

Aí que falei: É porque ele saiu, ele foi pro Japão.

E foram de novo. Falou: Amanhã eu volto. Se amanhã você não estiver desmanchando, se você não mudar, então, amanhã, não sei o que eu vou fazer.

Aí fiquei quieto. Depois que eu lembrei do papel. Eu vou mostrar pra ver se ele vai valer isso ai.

Aí, outro dia voltaram. Porque ele queria vender essa terra, porque o Dito Paulino já morava nessa terra.

Então eles estavam sócios os dois. Entrando para vender o lugar. E sem saber o Sessé. Aí, um pouco da terá diz que vai dar pra gente.

Aí outro dia voltaram com a pick-up, chegaram. E as casas, o mesmo, igual. Ninguém dos índios tirava ou mexia.

E chegaram lá e ele falou pro Dito Paulino: Como é que nós vamos fazer com esses índios aí?

Aí que o Dito Paulino, não sei se pensaram nesse problema aí: Bom já que os índios não estão querendo sair mesmo, então vamos partir a parte assim e aí, o 
lado que não tem ninguém, fazemos lavoura. E ali embaixo também e nós ficamos no meio. E vai cortar por baixo e por cima.

Aí o cara falou: Agora que vocês não vão sair mesmo, então nós queremos dividir. Pra cá nós queremos fazer lavoura e pra lá nós queremos também fazer lavoura.

Aí que eu lembrei do papel. Aí eu tirei o papel. Aí eu mostrei pro cara: Agora, esse papel que eu tenho, o japonês fez, mas não sei se prestou ou não prestou. Você lê aí, você pode ler isso aí. Aí eu botei na mesa, o cara pegou, nem falou, mas ele leu tudo.Aí ele passou para a mulher. A mulher dele também leu, mas não falaram nada. Mas eu nem escutei também. Só arrumando, mexendo com máquina velha, essa aí.

Aí depois a mulher passou o papel na minha mão, o marido falou: Daqui a pouco nós voltamos. $\mathrm{E}$ até hoje aquele cara não apareceu. Sumiu, sumiu mesmo. Então assim, foi assim." 
ANEXO B - Roteiro básico para entrevistas

Estamos conversando sobre as abelhas você poderia me falar sobre as abelhas?

Me conte sobre as abelhas

E essas abelhas como elas são

Existem outras alem dessas

Elas fazem o que

O que essa abelha faz

E tem alguma coisa que se usa dessa abelha

Todas são assim

Como é que você sabe disso

Me explica mais, acho que também estou aprendendo agora sobre isso

E essa abelha como é que se olha o ninho

Como será que elas fazem pra viver todas dentro dessa casa

E pra mexer nela

Posso aprender algumas coisas dessa abelha ouvindo sobre ela

Sempre que nós conversamos sobre as abelhas parece que estamos aprendendo mais coisas delas

Vamos falar com os mais velhos pra ver se tem mais alguma coisa que eles gostam de falar sobre isso

Que bom que estamos falando sobre essas abelhas preciso anotar para não esquecer 
ANEXO C - Palavras ou expressões do idioma Guarani m'byá usadas no texto

A'YRE: larvas de abelhas.

AGUARAKAVY: certa etnoespécie de vespa.

AKÃ MOTÕ: certa etnoespécie de abelha sem ferrão.

AKÃ: cabeça.

AKÃ: cabeça.

$A P E K U \tilde{U}:$ língua.

APU'A: redondo.

ARAPYAU: período do ano de temperatura mais quente (estação de verão).

ARAYMA: período do ano de temperatura mais fria (estação de inverno).

El: mel ou abelha na forma generalizada.

EI GUAXU: certa etnoespécie de abelha com ferrão.

EI MIRĨ: certa etnoespécie de abelha sem ferrão.

EI MIRĨ'l: certa etnoespécie de abelha sem ferrão.

EI PYTÃ: certa etnoespécie de abelha sem ferrão.

EI RAPUA: certa etnoespécie de abelha sem ferrão.

EI RAVIJU: certa etnoespécie de abelha sem ferrão.

EI RUXU: certa etnoespécie de abelha sem ferrão.

EI TAPEXUA: certa etnoespécie de abelha sem ferrão.
EI TATA: certa etnoespécie de abelha sem ferrão.

EIRO: ninho de abelha.

EIXU: ninho de vespas e abelhas com ferrão de forma arredondada.

EIXU GUAXU: certa etnoespécie de vespa.

ETÃ: comunidade ou colônia.

ETÃNGUE: favo onde as abelhas depositam mel, pólen e crias.

EVI: traseiro.

EVORAKUE: pólen.

EXA: olho.

GUARYKUA: certa etnoespécie de abelha sem ferrão.

GUAXU: grande.

I: pequeno (funciona como diminutivo no sufixo).

IJAPU'A: ele é redondo.

IRAITY: cera de abelhas.

IXY: mãe (referente à abelha rainha, mãe de todas).

JATEl: certa etnoespécie de abelha sem ferrão.

JAXI: lua.

JURUÁ: não índio (branco). Juruá literalmente quer dizer "boca com cabelo", se referindo aos europeus na época da invasão do continente. Não se sabe qdo. o termo surgiu, mas tornou-se a forma genérica dos M'byá se referirem aos não-índios.

$K A ' A$ : erva mate. 
KA'l AKÃ PEKE: expressão que pode significar "a cabeça do macaco" ou, "o osso fino da cabeça do macaco".

KÃGUE RAXY: reumatismo.

KAVI XI: certa etnoespécie de vespa.

KAVY ETÃ: ninho de vespas que não produzem mel.

KAVY TATURÃ: certa etnoespécie de vespa.

KAVY TYPEXAĨ: certa etnoespécie de vespa.

KAVY: qualquer etnoespécie de vespa (usado para forma generalizada).

KRAXAl: certa etnoespécie de abelha sem ferrão.

KUARAY: sol.

$K Y^{\prime} A$ : cor ferrugem.

$K Y X E$ : faca.

MAMANGA GUAXU: certa etnoespécie de abelha com ferrão.

MAMANGA ĩ: certa etnoespécie de abelha com ferrão.

MAMANGA PARA: certa etnoespécie de abelha com ferrão.

MAMANGA PYTÃ: certa etnoespécie de abelha com ferrão.

MAMANGA UŨ: certa etnoespécie de abelha com ferrão.

MAMANGA: certa etnoespécie de abelha com ferrão.

MANDORI: certa etnoespécie de abelha sem ferrão.

MIRĨ: pequeno.

MOTÕ: botão.
NE'Ẽ PYAU: novo tempo. Essa expressão pode significar "espírito novo".

OGUE: folha de vegetais.

OKẼ: porta.

OPY: casa de rezas.

PARA: enfeite.

PEPO: asa.

PETỸ: fumo de corda.

PETỸGUA: cachimbo usado para fumar o petỹ.

PO: mão.

$P Y:$ pé.

$P Y$ 'A: estômago.

PYTÃ: cor vermelha ou marrom.

PYTÃ: cor vermelha.

TAMBOJAPE: tipo de alimento preparado à base de milho.

TATA ENDY: vela manufaturada a partir da cera de abelhas, usada para iluminação.

TATU: tatu (animal).

TATURÃ: parece com as costas do tatu, mas não é.

TAYRAl: crias em estado larval.

TAYRAI: favos que abrigam as crias em estado larval.

UŨ: cor preta.

VORÁ: nome que os não-indios dão à abelha ei pytã.

$X \tilde{I}$ : bico, ponta (pode ser usado para designar nariz).

YI: barriga.

YRU: caixa de abelha para abrigar ninho de abelhas. 
YTXY: produto das abelhas que recobrem 0 interior da colméia (própolis).

YVY El: certa espécie de abelha sem ferrão.

YVY MARÃ EY: é uma expressão traduzida como "terra sem mal" ou "solo intacto, que não foi edificado".

YVYRA KUA: oco da árvore.

YVYRA: árvore ou madeira.

YXIPO: cipó. 
ANEXO D - PLANTA DE IDENTIFICAÇÃO

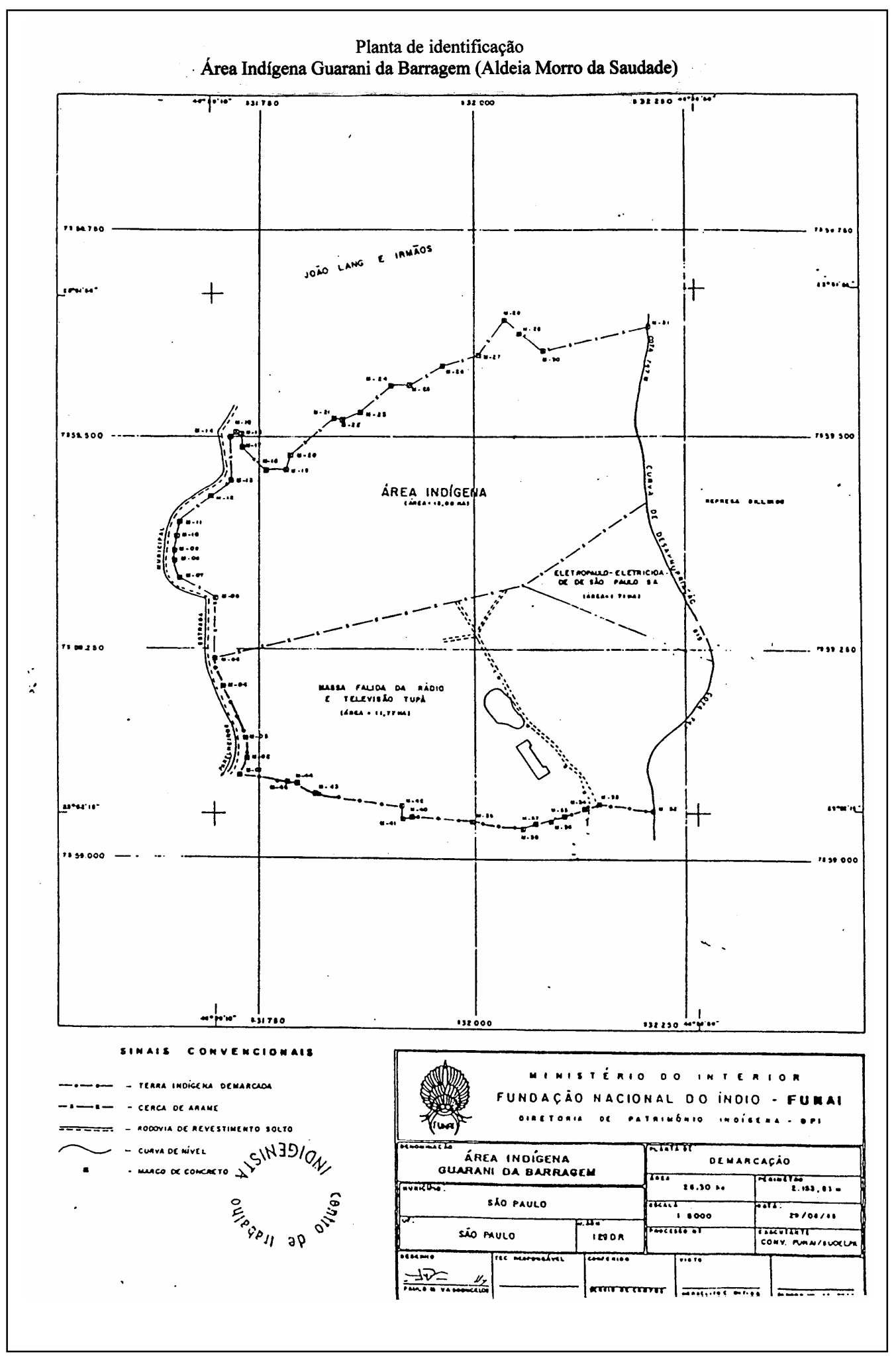




\section{REFERÊNCIAS BIBLIOGRÁFICAS}

AB'SÁBER, A.N. As etnociências e o legado de Darrell Posey. Criatividade na investigação permitiu uma abordagem nova de conhecimentos tradicionais. Scientific American Brasil, n.3, p.98, 2002.

ALMEIDA, M.C. Complexidade e cosmologia da tradição. Belém: EDUEPA/UFRN/ PPGES, 2001. 145p.

ALVES, S.B. Patologia e controle microbiano: vantagens e desvantagens. In: ALVES, S.B. Controle microbiano de insetos. 2.ed. Piracicaba: FEALQ, 1998. p.21-37.

ANCHIETA, J. Cartas. Informações, fragmentos históricos e sermões. São Paulo: Itatiaia/EDUSP. [1560], 1988. 562p.

ANDRADE, H. São Cipriano, o Bruxo. Rio de Janeiro: Pallas. 2000. 394p.

ATRAN, S. Cognitive foundations of natural history: towards an anthropology of science. Cambridge University Press, 1990. 360p.

BALLÉ, W. Cultura na vegetação da Amazônia Brasileira. Belém: Museu Paraense Emílio Goeldi, p.95-109. 1989. (Coleção Mário Galvão)

BARAJAS, E.C.L. Los animales usados en la medicina popular mexicana. México: Imprenta Universitária, 1961. 257p.

BARNES, R.D. Zoologia dos invertebrados. 4.ed. São Paulo: Livraria Roca, 1990. $1179 p$. 
BEATTIE, A.J. Discovering new biological resourses: chance or reason? BioSciente. v.42, n.4, p.290-292, 1992.

BECKERMAN, S. The abundance of protein in Amazon: A reply to Gross. American Anthropologist, v.81, n.3, p.533-560, 1979.

BERLIN, B. Ethnobiological classification: principles of categorization of plants and animals in traditional societies. Nova Jersey: Princeton University Press, 1992. $335 p$.

BERÓN, G.E. Etnoentomologia. http://insetariumirtual.com/hemeroteca/ hemeroteca.htm (20 jan. 2000)

BERREMAN, G.D. Anemic and emetic analyses in social anthropology. In: American Anthropologist, v.68, p.346-354, 1966.

BIERSACK, A. Saber local, história local: Geertz e Além. In: HUNT, L. (Org.). A nova história cultural. São Paulo: Martins Fontes, 2001. p.97-130.

BLUM, M.S. The limits of entomofagy: a discretionary gourmand in a world of toxic insects. The Food Insects Newsletter, v.7, n.1, p.6-11, 1994.

BORELLI, S.H.S.; LUZ, M.L.M. Introdução. In: MONTEIRO, J.M.; RANGEL, L.H.; LUZ, M.L.M.; BARBOSA, A.; LADEIRA, M.I.; BORELI, S.H.S. Índios no Estado de São Paulo: resistência e transfiguração. São Paulo: Yankatu Editora/Comissão PróÍndio de São Paulo, 1984. p.9-19.

BROWN, C.H.; CHASE, P.K. Animal classification in Juchitan, Zapotec. Journal of anthropologica Research, v.37, p.61-70, 1981.

BRUENING, Mons. H. Abelha Jandaira. Natal. v.557, 1990. 181p. (série C) (Coleção Mossoroense)

BUENO, F.S. Vocabulário Tupi-Guarani Português. 5.ed. São Paulo: Brasilivros, 1987.630p. 
BUSHNELL, D.I. Myths of the Louisiana Choctaw. American Anthropologist. n.12, p.526-535, 1910.

CABEZA DE VACA, A.N. Naufrágios y comentários. Madri: História, 1984. 318p.

CADOGAN, L. Ayvu Rapyta, textosmíticos de los Mbyá - Guarani de Guaira. Antropologia. n.5. Faculdade de Filosofia Ciêcias e Letras/USP. 217p. 1959a. (Boletim 227)

CADOGAN, L. Breve contribuición ao estúdio de la nomemclatura Guarani em botânica. Asuncion: Ministério de Agricultura y Guanaderia/Servicio Técnico Interamericano de Cooperaciónc Agrícola. 49p. 1955.

CADOGAN, L. Como interpretánlos Chiripá (Avá Guarani) la danza ritual. Faculdade de Filosofia Ciências e Letras, Universidade de São Paulo, v.7, p.65-99, 1959.

CADOGAN, L. Diccionário Mbyá-Guarani-Castelhano. Assunción: CEADUC/CEPAG, 1992. 211p.

CADOGAN, L. La lengua Mbyá-Guarani, Boletin de Filologia, v.5, p.649-670, 1949.

CAILLOIS, R. O louva-a-deus religioso. In: CAILLOIS, R. Le mythe et I'homme. Paris: Editions Gallinard, 1938. p.31-63.

CAMARGO, J.M.F.; POSEY, D.A. O conhecimento dos Kayapó sobre as abelhas sociais sem ferrão (Meliponidae, Apidae, Hymenoptera): notas adicionais. Boletim Museu Paraense Emílio Goeld. v.6, n.1, 1990. p.17-42. (Série Zoologia)

CAPOBIANCO, J.P.R.; WHATELY, M. Billings 2000: ameaças e perspectivas para o maior reservatório de água da região metropolitana de São Paulo. Relatório do diagnóstico socioambiental participativo da bacia hidrográfica da Billings no período de 1989-1999. São Paulo: Instituto Sócioambiental/Fundo Estadual de Recursos Hídricos, 2002. 59p. 
CAPPAS-E-SOUSA. J.P. Los Dioses Mayas y los Meliponíneos (Hymenoptera: Meliponinae). In: LATINOAMERICANO 6.; CONGRESO NACIONAL DE ENTOMOLOGIA 31., Cd De Mérida, Yucatán, 1996. Memórias. (México): Sociedad Mexicana de Entomologia, 1996. p.31.

CAPPAS-E-SOUSA. J.P. Os Maias e a Meliponicultura. In: JORNADAS DE LA ASOCIACIÓN ESPAÑOLA DE ENTOMOLOGIA 14., Cuenca, 1995. Resumos. (Espanha): Asociación Española de Entomologia \& Consejería de Agricultura y Médio Ambiente. 1995. p.146.

CARDONA, G.R. La foresta di Piume, manuale de etnoscienza. Roma: Ed. Laterza, 1985. 193p.

CARRERA, M. Escarabeoideos fúnebres e sagrados. Revista Brasileira de Entomologia, v.39, n.2, p.475-477. 1995.

CASAL, M.A. Corografia brasílica. Belo Horizonte: Itatiaia, 1976. 342p. (Coleção Reconquista do Brasil, v.27)

CHEN, Y. Ants used as food and medicine in Chine. The Food Insects Newsletter, v.7, n.2, p.1, 8-10, 1994.

CLASTRES, H. Terra sem mal: o profetismo Tupi-Guarani. São Paulo: Brasiliense, 1978. 178p.

CLASTRES, P. A fala sagrada: mitos e cantos sagrados dos índios Guarani. Campinas: Papirus, 1990. 144p.

CLASTRES, P. A sociedade contra o estado: pesquisa de antropologia política. Rio de Janeiro: Francisco Alves, 1978. 152p.

CLAUSEN, L.W. Insect fact and folklore. New York: Macmillan, 1954. 194p.

CLÉMENT, D. L'ethnobiologie/ethnobiology. Anthropologica, n.49, p.7-34, 1998a. 
CLÉMENT, D. The historical foundations of ethnobiology (1860-1899). Journal of Ethnobiology, v.18, n.2, p.161-187. 1998b.

CLÉMENT, D. Why is taxonomy utilitarian? Journal of Ethnobiology, v.15, p.1-44, 1995.

CLIFTON, J.A. Introduction to cultural anthropology: essays in the scope and methods of the science of man. Boston: Hougton Mifflin, 1968. 564p.

COIMBRA JUNIOR, C.E.A. Estudos de ecologia humana entre os Suruí do Parque Indígena Aripuanã, Rondônia. 1. O uso de larvas de coleópteros (Bruchidae e Curculionidae) na alimentação. Revista Brasileira de Zoologia, v.2, n.2, p.35-47, 1984.

COLDING, J.; FOLKE, C. The relations among threatened species their protection, and taboos. Conservation Ecology, v.1, n.1, p.1-19, 1997.

CONCONI, J.R.E.; PINO, J.M. The utilization of insects in the empirical medicine of ancient Mexicans. Journal of Ethnobiology, v.8, n.2, p.195-202, 1988.

CORTOPASSI-LAURINO, M.; GELLI, D.S. Analyse pollinique, propriétés physicochimiques et actionantibacterienne des miels d'abelles africanisées Apis mellifera et Meliponinés du Bresil. Apidologie, v.22, p.61-73, 1991.

COSTA-NETO. E.M. Insetos como fontes de alimentos para o homem: valoração de recursos considerados repugnantes. Interciencia, v.28, n.3, p.1-6, 2003.

COSTA-NETO. E.M. Introdução à etnoentomologia: considerações metodológicas e estudo de casos. Feira de Santana: Imprensa Universitária. Universidade Estadual de Feira de Santana - UEFS, 2000. 131p.

COSTA-NETO. E.M. Manual de Etnoentomologia. v.4. Zaragoza: 2002. 104p. 
D'OLNE CAMPOS, M. Etnociência ou etnografia de saberes, técnicas e práticas? In: SEMINÁRIO DE ETNOBIOLOGIA E ETNOECOLOGIA DO SUDESTE. 2002. AMOROZO, M.C.M.; MING, L.C.; SILVA, S.P. (Ed.). Rio Claro - SP, 2002. Métodos de coleta e análise de dados em etnobiologia, etnoecologia e disciplinas correlatos. Rio Claro: UNESP/CNPq, 2002. p.47-92.

D'OLNE CAMPOS, M. Fazer o tempo e o tempo do fazer: ritmos em concorrência entre o ser humano e a natureza. Ciência e Ambiente, v.8, p.7-33, 1994.

DAOUST, M.V. On some eggs of insects employed as human food, and giving rise to the formationof Oolites in laucustrine limestone in México. Annual Magazine Natural History, v.2, p.78-80, 1958.

DAVIDOFF, C. Bandeirantismo: verso e reverso. São Paulo: Brasiliense, 1982. 98p.

DEFOLIART, G. Insect as food in indigenous population. In: POSEY, D.A.; OWERAL, W.L. (Org.). Ethnobiology: implications and applications. INTERNATIONAL CONGRESS OF ETHNOBIOLOGY. Belém, 1990. Proceedings Belem: Museu Goeld. 1990. p.145-150.

DELONG, D.M. Man in a world insects. Annual Report of the Smithsonian Institution. Washington: 1962. p.423-440.

DOOLEY, R.A. Vocabulário do Guarani - vocabulário básico do Guarani contemporâneo (Dialeto Mbüá do Brasil). Brasília: Summer Institute of Linguistics. 1982. 321p.

DUFOUR. D.L. Insect as food: a case stude fronm the northwest Amazon. American Anthropologist. v.89, p.383-397, 1987.

EFFLATOUN, B. The development of enthomological science in Egypt. Trans. In: INTERNATIONAL CONGRESS OF ENTOMOLOGY, Nova York, 1928. International Congress of Entomology, Ithaca: Editora Ithaca College, 1929. p.742-747. 
EGA, R.A.I.; OLA, F.B. Exploitation in crickets and termites as food sources in Nigeria. In: "ETHNOBIOLOGY: DIALOGUE BETWEEN CULTURES. FORGING MEANINGFUL PARTNERSHIPS", 6. Whakatane, 1998. Abstracts. New Zealand, 1998. p.21.

ELLEN, R.; HARRIS, H. Concepts of indigenous environmental knowledge in scientific and development studies literature: a critical assessment. http://lucy.ukc.ac.uk/Rainforest/SML files/Occpap/indigknow.occpap TOC.html (20 Oct. 2004)

ELLIS JUNIOR, A. O bandeirismo paulista e o recuo do meridiano. São Paulo: Nacional, 1938. 333p.

ERWIN, T.L. A copa da floresta tropical: o coração da diversidade biótica. In: WILSO, E.O. (Org.). Biodiversidade. Rio de Janeiro: Editora Nova Fronteira, 1997. p.158165.

ERWIN, T.L.; SCOTT, J. Seazonal and size patterns, trophic structure, and richness of Coleoptera in the tropical arboreal ecosystem: The fauna of the tree Luchea seemannii Triana and Planch in the Canal Zone of Panama. Coleopterists Bulletin, v.34, 3, p.305-322, 1980.

ESSIG, E.O. The value of insects to the California Indians. Science Monthly. v.38, p.181-186, 1934.

FARIA, O.L.; LAMARTINE, H. Algumas Abelhas dos Sertões do Seridó. Arquivo Instituto de Antropologia de Natal. v.1, n.2, p.185-198, 1964.

FAZORANT, J.O. The place of insects in the traditional medicine of southwestern Nigéria. The Food Insects Newsletter. v.10, n.2, p.1-5, 1997.

FERREIRA, A.B.H. Novo Dicionário Aurélio da Língua Portuguesa. 2.ed., Rio de Janeiro: Ed. Nova Fronteira, 1986. 1838p. 
FERRER, D. Anual do Padre Diogo Ferrer para o provincial sobre a geografia e etnografia dos indígenas do Itatim. (21/08/1633). In: CORTESÃO, J. (Org.). Jesuítas e Bandeirantes no Itatim (1596-1760). Rio de Janeiro: Biblioteca Nacional. 1952. p.29-49.

FISHER, B.L. Insect behavior and ecology in conservation: preserving functional species interactions. Annals of the Entomological Society of America. v.91, n.2, p.155-158, 1998.

GADELHA, R.M.A.F. As missões jesuíticas do Itatim: estruturas sócio-econômicas do Paraguai colonial, séculos XVI-XVII. São Paulo: Paz e Terra, 1980. 342p.

GEERTZ, C. A interpretação das culturas. Rio de Janeiro: Zahar, 1978. 323p.

GEERTZ, C. O saber local: novos ensaios de antropologia interpretative. Petrópolis: Vozes, 1999. 366p.

GIANNINI, I.V. O conhecimento indígena da natureza. In: SIVA, A.L.; GRUPIONI, L.D.B. A temática indígena na escola. Brasília: MEC/MARI/UNESCO, 1995. cap. 8. p.206-207.

GLOCK, J. Die Symbolik der Bienen und ihrer Produkte in Sage. Kunst und Bräuchen der Völker. Heidelberg: Dichtung, Kultus, 1891. 411p.

GRAGSON, T.L.; BLOUNT, B.G. Introduction. In: GRAGSON, T.L.; BLOUNT, B.G. (Ed.). Ethnoecology: knowledge, resources, and rights. Atenas, Londres: The University of Georgia Press, 1999. p.7-18.

GREEN, S.V. The bushman as an entomologist. Antenna, v.22, n.1, p.4-8, 1998.

GREENE, E.S. Ethnocategories, social intercourse, fear and redemption. http://www.psyeta.org/sa/sa3.1/greene.html (15 Sep. 2000)

HAGAN, H. Die Insektennamen der Tupi Sprach. Stettin Entomologie Zeitschrift. v.24, p.252-259, 1863. 
HAGUETTE, T.M.F. Metodologías cuantitativas na sociología. Petrópolis: Vozes, 1992. $224 p$.

HARPAZ, I. Early entomology in the Middle East. In: SMITH, R.F. (Ed.). History of entomology. California: Palo Alto, 1973. p.243-278.

HARRIS, M. Cultural Materialism: the struggle for a science of culture. Nova York: Vintage Books, 1980. 381p.

HARRIS, M. History and significance of the emic/etic distinction. In: Annual Review of Antrhopology, v.5, p.329-350, 1976.

HAUBERT, M. Índios e jesuítas no tempo das Missões, séculos XVII-XVIII. São Paulo: Cia. das Letras, 1990. 313p.

HAUBERT, M. Les réductions guaranies et la théologie de la liberatón. Estudos IberoAmericanos. v.15, n.1, p.7-20, 1989.

HAYS, T.E. Nudumba folk biology and general principles of ethnobotanical classification and nomenclature. American Anthropologist. v.85, p.592-611, 1983.

HEADLAND, T.N. Introduction: a dialogue between Kenneth Pike and Marvin Harris on emics and etics. In: HEADLAND, T.N.; PIKE, K.K.; HARRIS, M. (Ed.). Emics and Etics: the insider/outsider debate. London: Sage Publ, 1990. p.13-24.

HEMMING, J. Red gold: the conquest of the Brazilian Indians, 1500-1760. Cambridge: Harvard University Press, 1978. 676p.

HITCHCOCK, S.W. Insects and Indians of the Americas. Bulletim of the Entomological Society of America, n.8, p.181-187, 1962.

HOGUE, C. Commentaries in cultural enthomology. 1. Definitions of cultural enthomology. Enthomological News, v.91, n.2, p.33-36, 1980. 
HOGUE, C. Cultural entomology. Annual Review of Entomology, v.32, p.181-199, 1987.

HOLLANDA, S.B. Caminhos e fronteiras. 3.ed. São Paulo: Cia. das Letras, 1995. $301 \mathrm{p}$.

HOLLANDA, S.B. Caminhos e fronteiras. Rio de Janeiro: Ed. J. Olympio, 1957. 334p.

HOLLANDA, S.B. Monções. 3.ed. São Paulo: Brasiliense, 1990. 326p.

HOLMBERG, E.L. Viaje a Misiones. Boletim da Academia Nacional de Ciência, v.10, p.252-288, 1887.

HOWES, F.N. Plants and Beekeeping. Londres: Faber \& Faber, 1945. 24p.

HUNN, E.S. The utilitarian factor in folk biological classification. American Anthropologist. v.84, p.830-847, 1982.

HUNN, E.S. What is traditional ecological knowledge? In: WILLIANS, N.; BAINES, G. (Ed.). Traditional ecological knowledge: wisdom for sustainable development. Canberra: Center for Resource and Enviromental Studies. ANU, 1993. p.13-15.

IHERING, H. Biologia das abelhas melíferas do Brasil. Boletim de Agricultura da Secretaria de Agricultura do Estado de São Paulo, v.31, n.5/8, p.435-506, 649-714, 1930.

IHERING, R. von. Dicionário dos animais do Brasil. São Paulo: Secretaria de Agricultura do Estado de São Paulo, 1940. 899p.

IHERING, R. von. Fauna do Brasil: texto explicativo do Atlas da Fauna do Brasil. São Paulo: Secção de Obras de "O Estado". 1917. 125p.

JARA, F. La miel y el aguijón. Taxonomia zooloógica y etnobiología como elementos em lãs nociones de gênero entre los Andoke (Amazônia Colombiana). Journal de la Societé dês Américanistes. n.82, p.209-258, 1996. 
JENKINS JUNIOR, R.E. Gerenciamento de informação para a conservação da biodiversidade. In: WILSO, E.O. (Org.). Biodiversidade. Rio de Janeiro: Editora Nova Fronteira. 1997. cap.27. p.292-302.

KATTER, F. Die Canthariden spec. Melë als Heilmitel der Tollwurth. Entomology Nachr, n.9, p.156-183, 1883.

KERN, A. A. Missões: uma utopia política. Porto Alegre: Mercado Aberto, 1982. 275p.

KERR, W.E.; CARVALHO, G.A.; NASCIMENTO, V.A. Abelha urucu biologia, manejo e conservação. Belo Horizonte: Fundação Acangaú. 1996. 144p. (Coleção Manejo da vida silvestre. v.2)

KLUCKHOLM, F.R. O método de "observação participante" no estudo de pequenas comunidades. Sociologia, v.8, n.2, p.103-118, 1946.

KNORTZ, K. Die inskten in sage, sitte, und literatur. Graeser: Annaberg/Sachesem. 1910. 151p.

KONO, K.; HISADA, M.; NAOKI, H.; ITAGAKI, T.; KAWAI, N.; MIWA, A.; YASUHARA, T. Pompilidotoxins (PMTXs), novel peptide neutotoxins in solitary wasp venoms. In: IUPCA INTERNATIONAL CONFERENCE ON BIODIVERSITY, 2, Belo Horizonte, 1999, Abstracts. Belo Horizonte: IUPCC/UFMG, 1999. p.78.

KORMONDY, E.J.; BROWN, D.E. Ecologia Humana. São Paulo: Atheneu Editora, 2002. 503p.

KUNIN, W.E.; LAWTON, J.H. Does biodiversity matter? Evaluating the case for conserving species. In: GASTON, K.J. (Ed.). Biodiversity: a biology of numbers and difference. Oxford: Blackwell Science. 1996. p.283-308.

LADEIRA, M.I. Aldeias livres Guarani do litoral de São Paulo e da periferia da capital. In: MONTEIRO, J.M.; RANGEL, L.H.; LUZ, M.L.M.; BARBOSA, A.; LADEIRA, M.I.; BORELI, S.H.S. Índios no Estado de São Paulo resistência e transfiguração. São Paulo: Yankatu Editora/Comissão Pró-Índio de São Paulo, 1984. p.123-144. 
LADEIRA, M.I. Espaço geográfico Guarani-Mbyá: significado, constituição e uso. São Paulo, 2001. 236p. Tese (Doutorado) - Faculdade de Filosofia Ciências e Letras do Estado de São Paulo, Universidade de São Paulo.

LADEIRA, M.I. O caminhar sob a luz - o território Mbyá à beira do Oceano. São Paulo, 1992. 199p. Dissertação (Mestrado) - Pontifícia Universidade Católica de São Paulo.

LADEIRA, M.I.; AZANHA, G. Os índios da Serra do Mar - A presença Mbyá-Guarani em São Paulo. São Paulo: Nova Stella Editorial. 1988. 71p.

LADEIRA, M.I.; COSTA, C.Z. A geografia mítica guarani-m'bya. A concretitude físico social do mundo (território) guarani-m'bya e o espaço mítico que o contém. In: SANTOS, M.; SOUZA, M.A.A.; SCARLATO, F.C.; ARROYO, M. (Org.). O novo mapa do mundo - Problemas geográficos de um mundo novo. São Paulo: HUCITEC-ANPUR, 1995. p.209-214.

LEME, P.T.A.P. Nobiliarquia paulistana histórica e genealógica. São Paulo: EDUSP, 1980. 3v.

LENKO, K.; PAPAVERO, N. Insetos no folclore. São Paulo: Conselho Estadual de Artes e Ciências Humanas. Imprensa Oficial do Estado, 1979. 518p.

LÉVI-STRAUSS, C. O Pensamento selvagem. São Paulo: Companhia Editora Nacional, 1970. 331p.

LIEBRECHT, F. Tocandyrafestes. Zoologie und Ethnobiologie, n.18, p.350-352, 1886.

LITAIFF, A. Les fils du soleil: mythes et pratiques des indiens Mbya-Guarani du Littoral du Brésil. 1999. s/n.p. Thèse (Doctor). Département d'anthropologie - Faculte dês arts et dês sciences - Université de Montreal. 
LITAIFF, A.; DARELLA, M.D.P. Os índios Guarani Mbyá e o Parque Estadual da Serra do Tabuleiro. Documentos Fórum de Pesquisa 3: "Conflitos Socioambientais e Unidades de Conservação". Anais. In: REUNIÃO BRASILEIRA DE ANTROPOLOGIA 22, Brasília: Universidade de Brasília, 2000. 45p.

MACHADO, J.A. Vida e morte do bandeirante. São Paulo: Itatiaia/Edusp. 1980. 247p.

MARQUES, J.G.W. Pescando pescadores: ciência e etnociência em um perspectiva ecológica. São Paulo: NUPAUB/USP, 2001. 258p.

MARSHALL, W. Neueröffnetes, wundersames Arzenei-Kästlein. Leipzig: s. ed. 1894. 1127p.

MARTIN, G.J. Etnobotánica: Manual de métodos. Montevideo: Editorial NordanComunidad, 1995. 240p.

MARTINEZ-CROVETO, R. La alimentación entre los índios Guaranies de Misiones (República Argentina). Etnobiológica, v.4, p.1-24, 1968.

MAYR, E. O desenvolvimento do pensamento biológico: diversidade, evolução e herança. Brasília: Editora Universidade de Brasília, 1998. 1108p.

MEIRELES, D.M. Guardiães da fronteira: rio Guaporé, século XVIII. Petrópolis: Vozes, 1989. 327p.

MELIÀ, B. A terra sem mal dos Guarani. Economia e profecia. Revista de Antropologia, v.33, 1990. 33-46p.

MELIÀ, B. El Guarani, conquistado y reducido: ensayos de etnohistoria. 4.ed. Assunção: Centro de Estudios antropológicos de la Universidad Católica "N. S. de la Asunción", 1988. 299p.

MELIÀ, B.; GRÜNBERG, G.; GRÜMBERG, F. Los Pai-Taviterã: etnografia Guarani Del Paraguay contemporâneo. Asunción: Separata Del Suplemento Antropológico, v.11, n.1-2, p.151-295, 1976. 
MÉTRAUX, A. A religião dos tupinambás e suas relações com a das demais tribos tupi-guaranis. São Paulo: Nacional, 1979. 225p.

MILLER, C.A. Determinants of the use of insects as human food within the Great Basin. The Food Insects Newsletter, v.10, n.1, p.1-4, 1997.

MINAYO, M.C.S. (Org.). Pesquisa Social: método e criatividade. Petrópolis: Ed. Vozes, 1998. 80p.

MONTEIRO, J.M. A escravidão indígena e o problema da identidade étnica em São Paulo colonial. Ciências Sociais Hoje, v.1, n.1, p.237-252, 1990.

MONTEIRO, J.M. Celeiro do Brasil: escravidão indígena e a agricultura paulista no século XVI. História, v.7, p.1-12, $1988 \mathrm{~b}$.

MONTEIRO, J.M. From Indian to slave: forced native labour and colonial society. In: São Paulo during the seventeenth century. Slavery and Abolition. v.9, n.2, p.105127, 1988a.

MONTEIRO, J.M. Os escravos índios de São Paulo no século XVII: alguns aspectos demográficos. Revista da Sociedade Brasileira de Pesquisa Histórica, v.5, p.1118, 1989.

MONTEIRO, J.M. Os Guarani e a história do Brasil meridional: Séculos XVI-XVII. In: CUNHA, M.C. (Org.). História dos índios no Brasil. São Paulo: Cia. Das Letras, 1992. p.475-504.

MONTEIRO, J.M. Vida e morte do índio: São Paulo colonial. In: MONTEIRO, J.M.; RANGEL, L.H.; LUZ, M.L.M.; BARBOSA, A.; LADEIRA, M.I.; BORELI, S.H.S. Índios no Estado de São Paulo: resistência e transfiguração. São Paulo: Yankatu Editora/Comissão Pró-índio de São Paulo, 1984. p.21-44.

MONTOYA, A.R. Vocabulario y tesoro de la lengua guarani ó más bien tupi. Nueva edición: mas correta y esmerada que la primera, y con las voces indias en tipo diferente. Viena/Paris, Faesy y Frick/Maisonneuve, 1876. 401p. 
MONTSERRAT, R.M.F. Línguas indígenas no Brasil contemporâneo. In: GRUPIONI, L.D.B. (Org.). Índios no Brasil. Brasília: MEC. 1994. 291-315p.

MOONEY, J. Myths of the cherokee and sacred formulas of the cherokee. (reimpres. v. 7/9 Annual Repots, Bureau of American Ethnology) Nashville: Elder Bookseller, 1972. 426p.

MORIN, E. La méthode. 2 - La vie de la vie. Paris: Éditions du Seuil, 1980. 168p.

MORRIS, M.G.; COLLINS, N.M.; VANE-WRIGHT, R.I.; WAAGE, J. The utilization and value of nondomesticated insects. In: COLLINS, N.M.; THOMAS, J.A. (Ed.). The conservation of insects and their habitats. Londres: Academic Press, 1991. p.319-347.

MURDOCK, G.P. Outline of cultural materials. New Haven: Yale University/Institute of Human Relations, 1950. 162p.

NAMBA, T.; MA, Y-H.; INAGAKI, K. Insect-derived crude drugs in the Chiness nong dynasty. Journal of Ethnopharmacology, n.24, p.247-285, 1988.

NAZAREA, V.D. Ethnoecology. Situated knowledge/located lives. Tucson. AZ. University of Arizona Press, 1999. 299p.

NIMUENDAJÚ, C.U. Apontamentos sobre os Guarani. Revista do Museu Paulista, v.8, p.9-57, 1954.

NIMUENDAJÚ, C.U. As lendas de criação e destruição do mundo como fundamento da religião dos Apapocúva-Guarani. São Paulo: HUCITEC/EDUSP, 1987. 156p.

NIMUENDAJÚ, C.U. Mapa etno-histórico de Curt Nimuendajú. Rio de Janeiro: IBGE/Fundação Instituto Brasileiro de Geografia e Estatística, 1981. 1p. 
NOELLI, F.S. Sem tekoha não hà tekó. (Em busca de um modelo etnoarqueológico da aldeia e da subsistência Guarani e a sua aplicação a uma área de domínio no delta do rio Jacuí - RS). Porto Alegre, 1993. 574p. Dissertação (Mestrado) Instituto de Filosofia Ciências e Letras, Pontificia Universidade Católica do Rio Grande do Sul.

NOGUEIRA, B.C.A. Vocabulário da "Conquista". Vocabulário das palavras Guaranis usadas pelo tradutor da "Conquista Espiritual" do Padre Antonio Ruiz de Montoya. Rio de Janeiro: Typ de Gleuzinger, 1879. 603p.

NOGUEIRA-NETO, P. A criação de abelhas indígenas sem ferrão. São Paulo: Tecnapis, 1970. 365p.

NOGUEIRA-NETO, P. Notas sobre a história da apicultura brasileira. In: CAMARGO, J.M.F. (Org.). Manual de apicultura. São Paulo: Ed. Agronômica Ceres, 1972. cap. 1, p.17-32.

NOGUEIRA-NETO, P. Vida e criação de abelhas indígenas sem ferrão. São Paulo: Ed. Nogueirapis, 1997. 446p.

NORDENSKIÖLD, E. The Guarani invasion of the Inca Empire in the sixteenth century: na historical indian migration. Geographical Review, v.4, p.103-121, 1917.

O'BRYAN, A. The Dîné: origin myths of the Navajo Indians. Bureau of American Ethnology. Washington: Smithsonian Institute, 1956. (Bulletin, 163)

OTT, J. The delphic bee: bees and toxic honeys as pointers to psychoactive and other medicinal plants. Economic Botany, v.52, n.3, p.260-266, 1998.

OVERAL, W.L. Introduction to ethnozoology: what it is or could be. In: POSEY, D.A.; OWERAL, W.L. (Org.). Ethnobiology: implications and applications. INTERNATIONAL CONGRESS OF ETHNOBIOLOGY. Belém, 1990. . Proceedings Museu Goeld, 1990. p.127-129. 
POSEY, D.A. Algumas observaciones ethnoentomológicas sobre grupos amerindos en la América Latina. America Indígena, v.15, n.1, p.105-120, 1980.

POSEY, D.A. Ethnoentomological survey of Brasilian Indians. Enthomology General, v.12, n.2 / 3, p.191-202, 1987a.

POSEY, D.A. Ethnoentomology of the Goroti Kayapó of Central Brazil. Georgia, 1979. p.574, Tese (Doutorado) - University Georgia.

POSEY, D.A. Ethnomethodology as na emic guide to cultural systems: the case of the insects and the Kayapó Indians of Amazônia. Revista Brasileira de Zoologia. v.1, n.2, p.135-144, 1983.

POSEY, D.A. Etnobiologia: teoria e prática. In: RIBEIRO, D. Suma Etnológica Brasileira. Petrópolis: Editora Vozes. 1096a. v.1, p.15-25.

POSEY, D.A. Etnoentomologia de tribos indígenas da Amazônia. In: RIBEIRO, D. Suma Etnológica Brasileira. Petrópolis: Editora Vozes, 1986. v.1. p.251-271.

POSEY, D.A. Folk apiculture of the Kayapó Indians of Brazil. Biotropica, v.15, n.2, p.154-158, 1983a.

POSEY, D.A. Interpreting and Applying the "Reality" of Indigenous Concepts: what is necessary to learn from the natives? In: REDFORD, K.H.; PADOCH, C. (Ed.). Conservation of Neotropical Forests: working from traditional resource use. New York, Columbia University Press, 1992. p.21-34.

POSEY, D.A. O conhecimento entomológico Kayapó: etnometodologia e sistema cultural. Anuário Antropológico. Brasília, Universidade de Brasília. v.8. p.109-125. 1982.

POSEY, D.A. Temas de inquirições em entnoentomologia: algumas sugestões quanto à geração e teste de hipóteses. Boletim do Museu Paraense Emílio Goeldi, v.3, n.2, p.99-134, 1987. (Série Antropológica) 
RAMOS-ELORDUY, J. Creepy crawly cuisine: the gourmet guide to edible insects. Vermont: Park Street Press, 1998. 150p.

RAMOS-ELORDUY, J. La etnoentomología atual em México em la alimentación humana, em la medicina tradicional y em la reciclaje y alimentación animal. In: CONGRESO NACIONAL DE ENTOMOLOGIA, 35., Acapulco, 2000. Memórias. Acapulco: Sociedade Mexicana de Entomologia, 2000. p.3-46.

RATCLIFFE, B.C. The significance of scarab beetles in the ethnoentomology of nonindustrial, indigenous peoples. In: POSEY, D.A.; OVERAL, W.L. (Org.). Ethnobiology: implications and applications. Belém: Museu Goeld, 1990. p.159155.

REAUMUR, M. Memoires pour servir a l'histoire des insectes. Paris: Imprimerie Royale, 1740.728p.

RIBEIRO, B.; KENHIRI, T. Chuvas e constelações. Calendário econômico Dêssana. Ciência Hoje. v.6, n.36, p.26-37, 1987.

RIBEIRO, B.G. O índio na cultura brasileira. Rio de Janeiro: Editora Renavan, 1991. $186 p$.

RODRIGUES, A.D. Línguas brasileiras. Para o conhecimento das línguas indígenas. São Paulo: Loyola, 1994. p.134.

ROUÉ, M. Novas perspectivas em etnoecologia: saberes tradicionais e gestão dos recursos naturais. In: CASTRO, E.; PINTO, F. (Ed.). Faces do trópico úmido. Belém: CEOUP. 1997. (cópia s/n.)

SAHLINS, M. Cultura e rasão prática. Rio de Janeiro: Zahar, 1979. 258p.

SAINT-HILAIRE, A. Relation d'um empoisonnement cause par lê miel de la guepe lecheguana. Annual Sience Natural, v.4, p.340-344, 1824. 
SAINT-HILAIRE, A. Viagem às nascentes do Rio São Francisco e pela Província de Goiás. São Paulo: Cia Edit. Nacional. [1847]. v.2, 237p., 1944.

SAKAGAMI, S.F. Stingless bees. In: HERMANN, H.R. Social Insects. New York: Academic Press, 1982. cap. 4, v.3, p.361-423.

SAMPAIO, T. Tupi na geografia nacional. Vocabulário geográfico brasileiro. Salvador: Câmara Municipal de Salvador, 1955. 360p.

SANCHEZ-LABRADOR, Pd. J. Paraguay natural ilustrado: noticias de la natureza de paiz com la explicacion de phenomenos physicos generales y particulares: usos utiles, que de sus producciones pueden hacer varias artes. Ravenha (Paraguai). 1776. cap. 3, pt4, 245-266p. 1776.

SANTOS, M.C. Jesuítas e índios na sociedade missioneira: uma análise crítica da historiografia. Estudos Ibero-Americanos, v.13, n.1, p.71-108, 1987.

SANTOS-RODRIGUES, A. Aspectos etnobiológicos sobre o uso medicinal de abelhas nativas e seus produtos pelos índios Guarani M'byá". (compact disc) In: ENCONTRO DE ETNOBIOLOGIA E ETNOECOLOGIA DA REGIÃO CENTROOESTE, WORKSHOP DE PLANTAS MEDICINAIS DE MATO GROSSO DO SUL. Dourados, 2003. Anais. Universidade Federal do Mato Grosso do Sul e Universidade Estadual do Mato Grosso do Sul, 2003.

SANTOS-RODRIGUES, A.; ALONSO, W.G.; NOGUEIRA-NETO, P. Levantamento preliminar do conhecimento e uso de produtos das abelhas sem ferrão (Hymenoptera, Apidae, Meliponinae) em duas aldeias indígenas Guarani próximas à metrópole de São Paulo, Brasil. (compact disc) In: SIMPÓSIO DE ETNOBIOLOGIA E ETNOECOLOGIA 3., Piracicaba, 2000. Resumos. Piracicaba: ESALQ-USP/CNPq/FAPESP. 2000.

SCARBOROUGH, J. On the history of early entomology chiefly Greek and Roman, with a preliminary bibliography. Melsheimer Entomology Service, v.26, p.17-27, 1979. 
SCHADEN, E. Aculturação indígena: ensaio sobre fatores e tendencies da mudança cultural de tribos índias em contacto com o mundo dos brancos. São Paulo: Livraria Pioneira Editora, 1969. 333p.

SCHADEN, E. Aspectos fundamentais da cultura Guarani. Antropologia, Faculdade de Filosofia, Ciências e Letras. Universidade de São Paulo. 231p. 1954. (Boletim, 188)

SCHADEN, E. Caracteres específicos da cultura Mbyá-Guarani. Revista de Antropologia, v.11, n.1/2, p.83-94, 1963.

SCHADEN, E. Entre os índios do litoral paulista. Paulistana, n.23, p.16-18, 1948.

SCHMITZ, P.I.; GAZZANEO, M. O que comia o guarani pré-colonial. Revista de antropologia. v.6, p.89-105, 1991.

SCHWARZ, H. F. Domestication of stingless bees and rites connected with bee culture. Bulletin American Museu Natural History, v.90, p.142-160, 1948.

SEIGNOBOS, C.; DEGUINE, J.P.; ABERLENC, H.P. Les Mofu et leurs insectes. Journal d'Agricculture Traditionnel et de Botanique Applicabe, v.32, n.2, p.125-187, 1996.

SIGANOS, A. Bestiário Mítico. In: BRUNEL, P. (Org.). Dicionário de mitos literários. Rio de Janeiro: José Olympio, 1997. p.117-137.

SKINNER, A. The use of insects and other invertebrates as food by North American Indians. p.284-267, 1910.

SLIKKERVEER, L.J. Ethnoscience, "TEK" and its application to conservation. In: POSEY, D.A. (Ed.). Cultural and spiritual values of biodiversity. Londres: Intermediate Technology Publications, 1999. p.169-177. 
SOMBROEK, W.G. Amazon soils: a reconnaissance of the soils of the Brazilian Amazon region. Wageningen: Centre for Agricultural Publications and Documentation, 1966. 300p.

SOUZA-DIAS, J.P. Índice de drogas medicinais angolanas em documentos dos séculos XVI XVIII. Revista Portuguesa de Farmácia, v.45, n.4, p.174-184, 1995.

SPIX, J.B. von; MARTIUS, C.F.P. von. Viagem pelo Brasil. Instituto de História e Geografia Brasileira. Rio de Janeiro: Impr. Nac, 1938. v.2. 567p.

SPRADBERY, J.P. The impact of wasps on man. In: Wasps: an account of the biology and natural history of solitary and social wasps. Seattle: University of Washington Press, 1973. p.272-285.

STORNI, J.J.M.S. Hortus guaranensis: Flora. Tucumán: Edit. Univ. Nac. Tucumán UNT - Gabinete de Etinologia Biológica, 1944. 268p. (Publicación, 354)

STRELNIKOV, I.D. Les Kaa-îwva du Paraguay. In: CONGRESSO INTERNAZIONALE DEGLI AMERICANISTIS, 22., Roma, 1928. Anais. CONGRESSO INTERNAZIONALE DEGLI AMERICANISTIS, Roma. s.ed., 1928. p.333-366.

SUTTON, M.Q. Insect resources and plio-pleistocene hominid evolution. In: POSEY, D.A.; OVERAL, W.L. (Org.). Ethnobiology: implications and applications. In: INTERNATIONAL CONGRESS OF ETHNOBIOLOGY, 1., Belém, 1990. Proceedings Belém: Museu Goeld, 1990. p.195-207.

TEIXEIRA, R.F.A. As línguas indígenas no Brasil. In: SILVA, A.L.; GRUPIONI, L.D.B. (Org.). A temática indígena na escola. Novos subsídios para professores de $1^{\circ}$. e $2^{\circ}$. graus. Brasília: MEC/MARI/UNESCO, 1995. p.291-311.

TUXEN, S.L. Entomology systematizes and describes. In: SMITH, R.F.; MITTLER, T.E.; SMITH, C.M. History of entomology. Palo Alto: Annual Reviews. 1973. p.95-118.

VALLI, E. Golden harvest of the Raji. National Geographic, v.193, n.6, p.84-105, 1988. 
VELLARD, J. Une civilization du mile. Les indiens Guaiakys du Paraguay. Paris: Librarie Gallimard, 1939. 189p.

VIERTLER, R. Métodos antropológicos como ferramenta para estudos em etnobiologia e etnoecologia. In: AMOROZO, M.; MING, L.C.; SILVA, S.P. (Ed.). Métodos de coletas e análises de dados em etnobiologia, etnoecologia e disciplinas correlatos. Rio Claro: UNESP/CNPq. 2002. p.11-29.

VIVEIROS DE CASTRO, E.B. Nimuendaju e os Guarani. In: NIMUENDAJU, C. As lendas de criação e destruição do mundo como fundamento da religião dos Apapocúva-Guarani. São Paulo: HUCITEC/EDUSP, 1987. p.17-38.

WAGNER, M. Das zeidelwessen und sein Ordnung im Mittelalter und in der neuren Zeit. Müchen; s. ed. 1895. 235p.

WALLACE, A.R. On the insects used for food by the Indians of the Amazon. Transactions of the Entomological Society of London, v.2, p.241-244, 1982.

WEISS, H.B. An old use for cockroaches. Journal of the New York Entomological Society, v.54, p.166, 1946.

WEISS, H.B. Cockroaches for tetanus and indigestion. Journal of the New York Entomological Society. v.33, p.232, 1925.

WEISS, H.B. Entomological medicaments of the past. Journal of the New York Entomological Society. v.55, p.155-168, 1947.

WEISS, H.B. Insects and witchcraft. Journal of the New York Entomological Society, v.38, p.127-133, 1930.

WERNER, D. Healing in the Sierra Madre. Natural history, v.79, n.9, p.61-66, 1970.

WILSON, E.O. A situação atual da diversidade biológica. In: WILSON, E.O. (Org.). Biodiversidade. Rio de Janeiro: Editora Nova Fronteira. 1997. cap.1. p.3-24. 
WILSON, E.O. Diversidade da Vida. São Paulo: Ed. Schwarcz, 1994. 448p.

WYMAN, L.C.; BAILEY, F.L. Native Navajo methods for the control of insect pests.

Plateau O. Museum North Arizona, v.24, n.3, p.97-103, 1952.

WYMAN, L.C.; BAILEY, F.L. Navajo Indian ethnoentomology. Albuquerque: University of New Mexico, 1964. 158p.

ZAVALA, S.A. Orígenes de la colonización em el Rio de la Plata. México: Colégio de México, 1977. 708p.

ZENHA, E. Mamelucos. São Paulo: Revistas dos Tribunais, 1970. 275p.

ZIMIAN, D.; YONGHUA, Z.; XIWU, G. Medicinal insects in China. Ecology of Food and Nutrition, v.36, p.209-220, 1997.

ZIMMER, C. The healing power of maggots. Discover, n.8, v.14, p.17. ago., 1993. 